\title{
The Agricultural Development of Brazil
}

\section{G. Edward Schuh}

in collaboration with Eltwe Robarto Alves

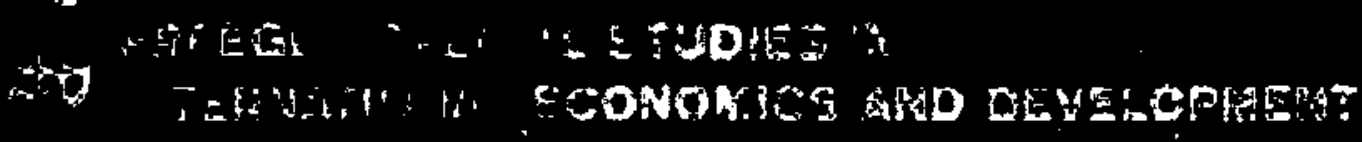


The book is dedicated to the many people who have fought with quite limited resources for the modernization of Brazilian agriculture. 
FOREWORD

This book is based on one of several agricultural "bench mark" studies undertaken under Ford Foundation sponsorship in Latin American countries during 1966 and 1967. The researchers addressed themselves to questions such as: What changes are taking place in each country's agricultural output and productivity? Are levels of per capita food production, human nutrition, and rural living rising? What relationships exist between the performance of the agricultural sector and the nation's total economic development? Can the strengths and weaknesses of the agricultural sector be identified? What are the major impediments to more rapid rates of advance? Among the means of accelerating agricultural development, which should be given priority? subjective judgments necessarily are involved in the analysis of such questions. The potential for improvement, however, is substantial and real.

If the potential is great, why has it not been realized? A partial answer is that much of today's advanced technology for food and fiber production is developed to meet the needs of production within a specific geographical area. Modern agricultural production techniques developed in temperate zones generally do not transfer directly to different environments. Moreover, it is difficult to project the rate at which new, well-adapted technology may be developed in a particular country. This, in turn, complicates attempts to estimate a nation's future comparative advantage in the production of a crop or an animal product. Historically, it was presumed that developing nations had relative advantages in agriculture, compared with industry; these countries were important exporters of agricultural products, including the food-grains. In recent years, however, the net flow of trade in basic food crops has been from the developed to the less-developed nations. 
Public and private investments in production research, educational programs, provision of fertilizer and other inputs, and infrastructure development compete for scarce resources. In the absence of systematic evaluation and policy guidelines, therefore, policy decisions concerning resource development and use may be the product of short-run pressures, rather than contributions to a rational plan.

This study of Brazil (and related studies in the series) indicates that several nations that formerly gave top priority to industrialization now are re-examining the potential contribution of agriculture to balanced development. Research in agricultural production technology carried on in tropical and subtropical regions has been greatly stimulated by the performance of the new Mexican wheat and Philippine rice varieties. Multidisciplinary teams have shown that substantial yield increases can be profitably obtained.

Although gapacity to advance production technology is necessary, this capability in itself constitutes only part of the total effort needed for rapid economic growth. Structural, institutional, policy, and organizational changes often are equally important. Work in the policy area, however, is often more controversial and harder to evaluate than is production research. As this study demonstrates, key questions in the policy-organization-planning area remain to be answered. It is at the interface where agriculture, industry, and public policy meet that the most significant questions are raised.

Lowell S. Hardin Ford Foundation June, 1968 
P REFACE

This diagnosis, or bench mark study, of Brazilian agriculture, undertaken at the request and under the sponsorship of the Ford Foundation, was started in the American summer of 1966. The objectives of the study were:

1. To determine for a recent historical period (five years suggested) the changes which have taken place in Brazil's agricultural output, productivity, per capita food production and consumption, levels of human nutrition, welfare of rural people, and contribution to the nation's economic development.

2. To determine what factors were associated with the measured changes and their contributions, and to identify impediments to more rapid rates of progress. (The objective here was to identify strengths and weaknesses in the agricultural sector as revealed by systematic analysis.)

3. To predict, within what appear to be the most realistic assumptions with respect to key economic, social, institutional, and population projections, the probable changes in factors, ratios, etc. during the decade ahead.

4. To array in priority order means of improving agricultural development in Brazil, providing estimates of costs and probable consequences of suggested innovations, programs, and public or private actions. Here the objective was to conceive of means for bolstering strengths and minimizing or eliminating the identified weaknesses in the agricultural sector and to place them in a general alternative-consequences framework. Food-population balance issues were to receive high priority.

The study is based in large part on secondary data and secondary sources. This involves data 
collected on a systematic basis by national or state statistical agencies--much of which has serious limitations-and individual studies made for theses of doutoramento, M.S.'s, or Ph.D.'s. We supplemented this by traveling to all parts of Brazil and attempting to talk with key agricultural people--primarily in teaching, research, or extension agencies.

Our modus operandi consisted of the following: Dr. Russell Youmans was hired full-time for a month in the United states to collect what basic data were available in washington and various U.S. libraries. The authors arrived in Brazil on June 10, 1966, and spent three weeks organizing the study and collecting as much basic data as possible in Rio de Janeiro. We then spent the next six weeks traveling, visiting key schools of agriculture and research institutions. The final three weeks of the summer were spent in Rio de Janeiro attempting to digest what we had learned and writing down analyses of individual sectors. We were assisted throughout this stay in Brazil by Sra. Maria Ignez Angeli Schuh, the senior author's wife.

Upon return to the United States in September, 1966, Dr. Schuh took the responsibility of organizing and collating the material collected, doing the analysis, and writing the manuscript. This was done while carrying the normal load of academic duties at Purdue University and serving as program advisor in agriculture for Ford Foundation-Brazil.

Mr. Alves read drafts of each chapter as they were written and corrected errors of fact and/or interpretation. In addition he served as a valuable sparring partner when Dr. Schuh wanted to discuss an issue. His impact on the final manuscript is substantial.

During the 1968-1969 academic year the manuscript was substantially revised by Dr. Schuh. This revision was based on review comments of a large number of people, both Brazilian and North American. Special thanks are due to Harry Ayer, Louis Hermann, and Larry Witt, each of whom gave detailed comments. Responsibility for the final manuscript is Dr. Schuh's, however.

The study itself is subject to serious limitations. Time limitations precluded the thorough 
analysis necessary for the rather ambitious project. The underlying data are known to be subject to serious weaknesses, and many times visits to institutions and places were not long enough to cross check impressions and probe deeply into problems and events.

However, policy decisions are being made and resources are being expended. We hope that we have at least asked the right questions, and that in some small way the allocation of developmental resources will be improved by the information generated in this study.

In a broader context, the "bench mark" set here may be not only to identify the state of development of Brazilian agriculture, but also to "bench mark" the state of our knowledge about the process of economic development in Brazilian agriculture. We hope that the study provides a starting point for more intensive studies of this process, and of the analysis necessary to develop more rational developmental policies. 
ACKNOWLEDGMENTS

The authors are indebted to many people and to many institutions. Among these are Ady Raul de Silva of the Ministry of Agriculture and the directors of the federal research institutes who took the time to explain their programs and organizations to us; the Fundação Getulio Vargas, which shared its library with us, answered questions, and generated much of the data used in the study; Ruy Miller Paiva, who is always ready to discuss Brazilian agriculture; Rubens Dias, who made his library available, provided data, and was of assistance in numerous other ways; members of the ABCAR system, who provided data and material, freely discussed their program, and at times provided transportation; and Ary Burger, who helped us with contacts in Rio Grande do Sul and arranged transportation on our visit to that state.

Dr. Schuh would especially like to thank Edson Potsch Maqalhães and Erly Dias Brandão who have done much to stimulate his interest in Brazil and who have taught him many things about Brazilian agriculture. We are both indebted in many ways to UREMG and its staff, not only for their direct contribution in this study but also for their past influence on both authors.

On the direct support side, our thanks go to Stacey Widdicombe, Ford Foundation representative in Brazil, who provided a pleasant and stimulating work environment and logistical support, and who made no complaint when we turned his library into a shambles with our work program; to Lowell Hardin, who conceived the idea of the "bench mark" studies for Latin American countries and who developed the rough outline for the study; and to Dr. Russell Youmans, who did the early work on collecting data. Morris Whitaker and Petronio Rios have been of tremendous help in updating and adding to the data for this revised version. 
Part of this revision was made while Dr. Schuh was research associate with the Development Advisory Service (DAS) of Harvard University. He is indebted to the DAS for the facilities and environment which it provided, as well as to his own department head, Dr. Charles E. French, for his encouragement, the resources he provided to make completion of the study possible, and for the opportunity he provided to do it in the first place. 
CONTENTS

Page

FOREWORD by LOWell s. Hardin

$v i i$

PREFACE

$i x$

ACKNOWLEDGEMENTS

xiii

LIST OF TABLES

$\mathbf{x x i}$

LIST OF ABBREVIATIONS

$\mathbf{x \times x}$

Chapter

1 DEVELOPMENT OF THE TOTAL ECONOMY

Characteristics of Recent Growth

Inflation and the Monetary situation

The External sector

17

Development Policies and Programs 19

Public Investment

Notes

2 POPULATION, MIGRATION, AND THE LABOR MARKET

The Population and Its Geographic

Distribution

Migration

Geographic Shifts

The Rural-Urban Flow

The Labor Market

Inter-Sectoral Changes in Employment

Income and Productivity Differentials 51

Summary

Notes

3 AGRICULTURE'S ROLE IN THE ECONOMY

Sectoral Breakdown of Income and Growth

Rates

70

Nutrition 
Agriculture as a Source of Export Earnings

Agricultural Export Potential

Agriculture's Role in Total Growth of the Economy

Expanding Non-Farm Labor Force

Capital for Industrialization

An Adequate Diet for the Total

Population

A Market for the Non-Farm Sector

A Source of Export Earnings

4 STRUCTURE AND CHARACTERISTICS OF BRAZILIAN AGRICULTURE

Agricultural Production and Trends

Trends in Agricultural Production

109

The Role of Coffee

120

Land Use and Organization

Regional Distribution of Farms

124

Land Use

128

130

The New Lands

133

Size Distribution of Land Holdings

141

Ownership Patterns

149

Agricultural Labor Force

149

Components of the Farm Labor Force

150

Product Distribution of the Labor

Force

Capital Formation

151

Mechanization

153

Regional Aspects

The Structure of Capital

Regional Distribution of Capital

158

161

164

The Use of Modern Inputs

165

170

172

Crop Yields

Livestock Productivity

178 Notes

Some Aggregate Productivity Analyses

15 THE EDUCATIONAL AND RESEARCH INFRASTRUCTURE FOR AGRICULTURE

The Education System

General Aspects of the Educational

Situation

Higher-Level Agricultural Training 
Agricultural Colleges 205

Veterinary Schools 223

Schools of Home Economics 225

Vocational Training in Agriculture 226

Agricultural Research 227

Research by the Federal Government 229

Research by State Governments 231

Research by Non-Government Agencies 236

Other Research Institutions 237

Summary and Conclusions 238

Extension Services $\quad 240$

Administrative Organization of ABCAR 244

Expansion of State Services 245

Evaluations of ABCAR-Type Programs 248

Other Extension-Type Organizations and Activities

Conclusions

248

250

Integration of Teaching, Research,

and Extension 251

Capability for Economic Policy Analysis 252

Conclusion $\quad 257$

Summary and Conclusions $\quad 257$

$\begin{array}{ll}\text { Notes } & 258\end{array}$

6 OTHER ASPECTS OF THE INFRASTRUCTURE AND SUPPORT FOR AGRICULTURE 260

Public Institutions and Organizations 260

Federal Ministry and state Secre-

tariats of Agriculture 260

INDA and IBRA 262

CNPq (The National Research Council) 263

CAPES (Council for Advanced Training of University-Level Personnel) 264

Other Governmental Entities 265

Support for Colonization 267

The General Character of Administration 268

Regional Development Agencies 269

Budget Support for Agriculture 283

Agricultural Policy $\quad 292$

Public Attitude and Support $\quad 298$

Notes $\quad 300$

7 MARKETS AND THE SUPPLY INDUSTRIES 301

Market Institutions Servicing the

Agricultural sector $\quad 301$

Markets for Agricultural Inputs 302 
The Transportation and Communication

System

308

Supply Industries

314

Machinery, Equipment, and Tractors

314

Fertilizers

315

Agricultural Credit

Chemical-Based Industries

326

Seeds

326

Power and Fue 1

327

Irrigation

328

Notes

329

- 8 SOME OF THE MAJOR FACTORS AFFECTING AGRICULTURAL PROGRESS

Factors Contributing to Agricultural Progress

A New, Favorable Attitude Towards Agriculture

Greater Appreciation of Scierice and Technology

A More Rational General Economic Policy

More Well-Trained Technicians

The Beginning of a Research Infrastructure

A Growing Industrial Sector

A Rich Endowment of Natural Resources Examples Within the Country Conclusion

Factors Inhibiting Agricultural Progress

An Abundant Supply of Land

The Lack of Production Technology

A Low Rate of Human Investment

A Limited Extension Service

The Lack of Integration of Teaching,

Research, and Extension

Inadequate Input Markets

Inefficient Product Markets

High Relative Price of Modern Inputs

A Deficient Credit Policy

An Inadequate Transportation System

Inflation

The Lack of Economic Policy Research

Fragmentation and Proliferation of

Support Institutions

Discrimination Against Agriculture 
Population Growth

Domestic Product and Personal Disposable Income

Demand

Consumption Levels

Income Elasticity of Demand

353

Projections of Potential Demand

356 Supply

368

369

Levels of Production

Estimates of Technical Production

Functions

Projections of the Supply of Factors

of Production

Projections of Potential Supply

Balance Between Demand and Supply

Coefficients of Consumption

Projections of Effective Demand

Projections of Effective Production

Balance

Concluding Comments

Notes

Conventional Proposals

Land Reform

Increased Colonization

417

Irrigation

418

The Marketing System

Some High-Priority Policies for strengthening the Agricultural Sector

Strengthening Agricultural Research

Increased Investment in Rural People

Development of Supply Industries for Modern Inputs

Strengthening of Labor Market Infrastructure

Some Complementary Policies

An Improved Credit Policy

An Improved Transportation and Communication System

A Rational Price Policy

Expanded Capacity for Economic 
Chapter

Improved Administrative Organization and Training

Concluding Comments

434

Notes

436

EPILOGUE

439

BIBLIOGRAPHY

445

ABOUT THE AUTHORS

457 


\section{LIST OF TABLES}

Table

Page

1 Regional Distribution of Brazilian Population, 1960

2 Gross Domestic Product Trends, 1960-1967 7

3 Some Macro Ratios, 1959-1966

4 Indexes of Real Product by Sectors, $1960-1967$

5 Major Industrial Groups in the Brazilian Economy, 1959

6 Industrial Production, Annual Changes, 1960-1967

7 Annual Rate of Inflation, Measured by

Implicit Price Deflator, 1958-1967

8 Federal Government Operating Subsidies to Transport, 1960-1965

9 Fixed Capital Formation, Change in Stocks, Balance of Payments, Gross Domestic Product, 1947-1966

10 Public and Private Investment in Gross Domestic Product, 1956-1964

11 Public, Private, and Total

Investment, 1947-1966

12 Population Growth, 1940-1970 (Projected)

13 Distribution and Density of Population, by Region, 1960

14 Concentration of Population in Littoral Areas, 1960 
15 Population Distribution by Region, 1950 and 1960

16 Population by State and Region, 1940 and 1950, and Internal Migration, 1940-1950

17 Population Changes Through Migration, 1940, $1950,1940-1950$

18 Relative Magnitude of Population Shifts, 1950 and 1940-1950

19 Quantity and Rate of Population Growth by Area of Residence, 1940, 1950, 1960

20 Estimated Rural-Urban Migration, 1940-1950 and $1950-1960$

21 People Economically Active by Sector, Age 10 and Over, $1940,1950,1960$

22 Employment in Major Sectors as Percent of Total Employed Labor Force, 1940, 1950, 1960

23 Monthly Wages of Unskilled Rural Labor, Selected States, 1959

24 Net Internal Income per Capita, Rural and Urban, 1947-1965

25 Real Internal Income per Economically Active Person, by Sector, 1940, 1950, 1960

26 Real Income by Sector, 1940, 1950, 1960

27 Indexes and Percentage Changes in Net Internal Product, 1947-1967

28 Real Internal Product, by Sector, 1947-1965

29 Rate of Growth, Agricultural and Industrial Sectors, 1920-1962

30 Sectoral Growth per Capita, 1920-1962

31 Growth Rates of Agricultural Production and Population, 1920-1962 
32 Real Growth in per Capita Food consumption, 1950-1964

33 Estimated Surpluses and Deficits of Food Nutrients, 1960

34 Surpluses and Deficits of Food Nutrients, 1970

35 Brazilian Exports (FOB), 1960-1967

86

36 Coffee Sector's Earning Capacity, 1953-1961

37 Coffee Production and Exports

38 Relative Wholesale Prices of Agricultural Products, 1948-1967.

39 Production and value of Twelve Important Crops, 1959 and 1966

40 Value of Livestock Herds, 1958 and 1966

41 Principal Livestock Herds, 1920-1966

42 Production of Milk, 1950-1966

108

43 Milk Production, by Region, 1958

44 Production and Value of Manufactured Milk Products, 1958 and 1966

45 Agricultural Revenue, by Product Groups, $1962-1964$

46 Regional Distribution of Agricultural

Revenue and Product Groups, 1962-1964

47 Index of Quantity Produced of Principal Agricultural products, Exclusive of Coffee, and Indexes of Population, 1947-1963/1967

48 Indexes of Quantity of Food Products, $1947 / 1951-1963 / 1967$

49 Indexes of Quantity of Food Products. of Animal Origin, 1950-1963 
50 Indexes of Quantity of Food Products of Plant Origin, 1950-1963

51 Price Indexes for Food Products of Plant Origin, 1950-1963

52 Indexes of Quantity of Principal Industriable Products, 1953-1963

53 Value of Exports of Principal Agricultural Products, 1949-1967

54 Role of Coffee in Income Formation and Exchange Earnings, 1947-1964

55 Area in Farms, by Region, 1940-1960

56 Percentage Distribution of Land in Farms and Number of Farms, by Region, and Relative Farm Size, 1940-1960

57 Percentage Distribution of Land in Farms by Major Land Use and by Region, 1950 and 1960

58 Temporary Crops: Total Hectares and percent Grown in Association with other Temporary Crops, by Region, 1950

59 Farms Growing Crops Singly or in Association, Farms Reporting Crop Grown by Resident Personnel, 1950

60 Changes in Land in Farm and in Crops, by Region, 1950-1960

61 Distribution of Cattle by Region, 1950 and 1960

62 Number and Area of Establishments, by Total Area, 1950 and 1960

63 Number and Area of Establishments, by Region, 1950 and 1960

64 Relative Importance of Classes of Farms, by Region, 1950 and 1960 
65 Change in Number of Farms and Area in Farm Land, by Size of Farm, 1950 and 1960

66 Distribution of New Farms, by Region, 1950-1960

67 Distribution of Workers by Major Land Use, 1950

68 Use of Machinery and Draft Animals, by Region, 1950

69 Use of Machinery and Draft Animals, by Region, 1960

70 Number of Farms, Tractors, and Plows, by Specified Areas, 1950 and 1960

71 Relation Between Number of Farms, Number of Hectares in Farm Land or in Crop Land, and Farm Equipment, by Specified Areas, 1950 and 1960

72 Labor, Tractors, and Plows per Farm and per Hectare, as a Percent of the National Average, 1950 and 1960

73 Percentage Distribution of Capital, by Form and Region, 1940 and 1965

74 Percentage Distribution of Capital, by Region, 1940 and 1965

75 Apparent Consumption of Fertilizer, by Region, 1953-1963

76 Establishments Using Electrical Energy, 1960

77 Yields of Selected Crops, 1950-1966

78 Yield Changes of Selected Crops, 1952-1954, $1960-1962,1964-1966$

79 Comparative Yields of Selected Crops, Brazil and other countries 
81 Production, Number of Hectares, Number of Persons Employed in Agriculture, and Productivity, 1940, 1950, 1960

82 General School Matriculation, 1947-1965

83 Percent of Students Ages 7-14 Enrolled in School, by Region, 1964

84 Index of Medium Schooling, 1950 and 1960

85 Index of Superior Schooling, 1950 and 1960

86 Enrollment in Higher Educational Institutions, by Field, 1960

87 National Expenditures for Education, by Leve 1 , 1959-1963

88 Education Expenditures as a Percentage of the Internal National Product, 1959-1963

89 Students per Thousand Inhabitants, Selected South American Countries, 1964

90 Per Capita Expenditures on Education, by state, 1959-1961

91 Graduates of Schools of Agronomy and Veterinary Medicine, 1940-1964

92 Location, Year of Establishment, and Enrollment of Colleges of Agriculture, $1964-1967$

93 Schools of Agronomy, 1958 and 1961

94 Schools of Veterinary Science, 1958 and 1961

95 Agricultural Experiments, by Type, 1961

96 State Extension Agencies: Budgets and Population Ratios

97 Expansion of State Extension Organizations , 1960-1966 
98 Capital-Formation Resources Mobilized by SUDENE, 1960-1965

99 Sectoral Distribution by SUDENE of Resources from National Treasury, 1962-1965

100 Indexes of Public Investment Realized in the Northeast, 1960-1964

101 External Funds Supplied to SUDENE, $1961-1964$

102 Sectoral Allocation of External Resources, 1965

103 Budget Resources of the Ministry of Agriculture, 1960-1964

104 Expenses Realized by the Ministry of Agriculture, 1944-1965

105 Federal Budget for Agriculture, 1966

106 Percentage Allocation of Loans, by Sector, of the National Development Bank, 1952-1962

107 Distribution of Funds, by Organization and Field, 1962-1965

108 Breakdown of Loans and Grants for Agriculture and Plant Sciences, 1962-1965

109 Development of Federal, state, and country Road Network

110 Commodities Transported by Rail, Highway, and Coastal shipping

111 Loans Granted by CREAI, 1963-1965

112 Ratio of Fertilizer Price to Product Price, Selected Products and Nutrients

113 Population Projections, by Sector and Age Group, 1965, 1970, and 1975 
114 Projected Rates of Growth in Real Disposable Income, to 1975

115 Annual Per Capita Consumption of Primary Products in Urban and Rural Sectors, 1960

116 Alternative Estimates of Food Consumption, by Product

117 Engel Coefficients and Income per Capita, Urban Population

118 Engel Coefficients and Income per Capita, Rural Population

119 Aggregate Potential Demand for Agricultural Products, 1960-1975

120 Potential Demand, Urban Population, 1960-1975

121 Potential Demand, Rural Population, 1960-1975

122 Potential Demand, Total Population, 1960-1975

123 Projections of Potential Demand, in rerms of Primary Product Equivalent, 1960-1975

124 Supply of Selected Agricultural Products, 1960

125 Gross Availability of Selected Agricultural Products, 1960

126 Farmland as a Percentage of Total Iand Area, $1940,1950,1960$

127 Land in Farms, 1940, 1950, 1960

128 Agricultural Land in Crops and Pastures, $1940,1950,1960$

129 Projections of the Active Population in Agriculture, 1960-1975 
130 Number of Tractors and Plows, 1940, 1950, 1960

131 Rates of Growth of Fixed Capital Necessary to Attain Estimated Demand, 1960-1975

132 Ministry of Planning Projection of Fertilizer Consumption, 1965-1975

133 Ministry of Agriculture-USAID Projection of Fertilizer Consumption, 1965-1975

134 Projected Rates of Increase in Fertilizer Use, 1960-1975

135 Projections of Factor Supplies, Annual Rates of Growth, 1960-1975

136 Annual Rates of Growth of Potential Supply of Agricultural Products, 1960-1975

137 Projections of Effective Demand, 1960-1975 388

138 Projections of Value Aggregate Effective Production, 1960-1975

139 Projections of Value of Potential Supply and Equilibrium Supply, 1960-1975

140 Projections of Effective Production, $1960-1975$

141 Composition of Domestic Supply and Effective Demand of Agricultural Products, $1960-1975$

142 Total Demand and Supply of Agricultural Products, 1960-1975

143 Initial Conditions for Projections of Demand and Supply, Selected Agricultural Products, 1960

144 Projections of Supply and Demand, Selected Agricultural Products, 1965

145 Projection of Demand and Supply, Selected Agricultural Products, 1970 
146 Projection of Demand and Supply, Selected Agricultural Products, 1975

147 Projections of Potential Deficits of Agricultural Products, 1965, 1970, 19754403

148 Projections of Effective Imports, Agricultural Products, 1965, 1970, 1975405

149 Projections of Potential Surpluses, Agricultural products, $1965,1970,1975406$

150 Projections of Effective Exports,

Agricultural Products, 1965, 1970, 1975 
ABCAR

ACAR

AIA

BNDE

CAPES

$\mathrm{CCN}$

CEPLAC

CIDA

CNEPA

CNPq

CREAI

DFPA

Associação Brasileiro de Crédito e Extensão Rural (Brazilian Association of Credit and Rural Extension)

Associação de Crédito e Extensằo Rural (Association of Credit and Rural Extension)

American International Association for Economic and Social Development

Banco Nacional de Desenvolvimento Econômico (National Bank of Economic Development)

Conselho de Aperfeiçoamento de Pessoal das Escolas Superiores (Council for Advanced Training of University-Level Personnel)

Centro das Contas Nacionais (Center of the National Accounts, Fundacão Getúlio Vargas)

Commissão Executiva, Plano de Recuperação Econômica Rural da Lavoura Cacaueira (Executive Commission, Plan of Rural Economic Recuperation of the Cocoa Crop)

Comitê Interamericano de Desenvolvimento Agricola (Inter-American Committee of Agricultural Development)

Centro Nacional de Ensino e Pesquisas Agronômicas (National Center of Agronomic Teaching and Research)

Conselho Nacional de Pesquisa (National Research Council)

Carteira de Crédito Agrícola e Industrial (Desk of Agricultural and Industrial Credit)

Divisão de Fomento da Producão Animal (Division for Promotion of Animal Production) 
DFPV

DM

DPEA

ECLA

EPEA

ETA

FAO

FGV

GDP

GERCA

GNP

IBGE

IBRA

IBRD

IBRE

IDB

INDA

IPA

Divisão de Fomento da Producão Vegetal (Division for Promotion of Crop Production)

Deutsch Mark

Departamento de Pesquisas e Experimentação Agropecuárias (Department of Agricultural Research and Experimentation)

Economic Commission for Latin America (U.N.)

Escritório de Pesquisas Econômica Aplicada (Bureau of Applied Economic Research)-also known as IPEA, Instituto de Pesquisas Econômicas Aplicadas (Institute of Applied Economic Research)

Escritório Têcnica de Agricultura (Technical Office of Agriculture)

Food and Agriculture Organization

Fundação Getúlio Vargas

Gross Domestic Product

Grupo Executivo de Racionalização da Cafecultura (Executive Group for the Rationalization of Coffee Production)

Gross National Product

Instituto Brasileiro de Geografía e Estatistica (Brazilian Institute of Geography and Statistics)

Instituto Brasileiro de Reforma Agraria (Brazilian Institute of Agrarian Reform)

International Bank for Reconstruction and Development

Instituto Brasileiro de Economia (Brazilian Institute of Economics, Fundação Getúlio Vargas)

Inter-American Development Bank

Instituto Nacional de Desenvolvimento Agricola (National Institute for Agricultural Development)

Instituto de Pesquisas Agronomicas (Institute of Agronomic Research, State of Pernambuco) 
IPEACO

IPEACS

IPEAL

IPEAN

IPEANE

IPEAS

NCr\$

OAS

SNPA

SUDENE

SUNAB

UREMG

USAID

Instituto de Pesquisas e Experimentação Agropecuárias do Centro Oeste (Institute of Agricultural Research and Experimentation of the Central West)

Instituto de Pesquisas e Experimentação Agropecuárias do Centro Sul (Institute of Agricultural Research and Experimentation of the Central South)

Instituto de Pesquisas e Experimentação Agropecuarias do Leste (Institute of Agricultural Research and Experimentation of the East)

Instituto de Pesquisas e Experimentação Agropecuárias do Norte (Institute of Agricultural Research and Experimentation of the North)

Instituto de Pesquisas e Experimentação Agropecuárias do Nordeste (Institute of Agricultural Research and Experimentation of the Northeast)

Instituto de Pesquisas e Experimentação Agropecuárias do Sul (Institute of Agricultural Research and Experimentation of the South)

New Cruzeiros

Organization of American States

Servico Nacional de Pesquisas Agronômicas (National Service of Agronomic Research)

Superintendência de Desenvolvimento do Nordeste (Superintendency for Development of the Northeast)

Superintendência Nacional de Abastecimento (National Superintendency for Food Supply)

Universidade Rural de Minas Gerais (Rural University of Minas Gerais)

U.S. Agency for International Development 
The Agricultural Development

of Brazil 
Population Densities of Brazilian States

(Inhobitonts Por Sq. Km., 1960)

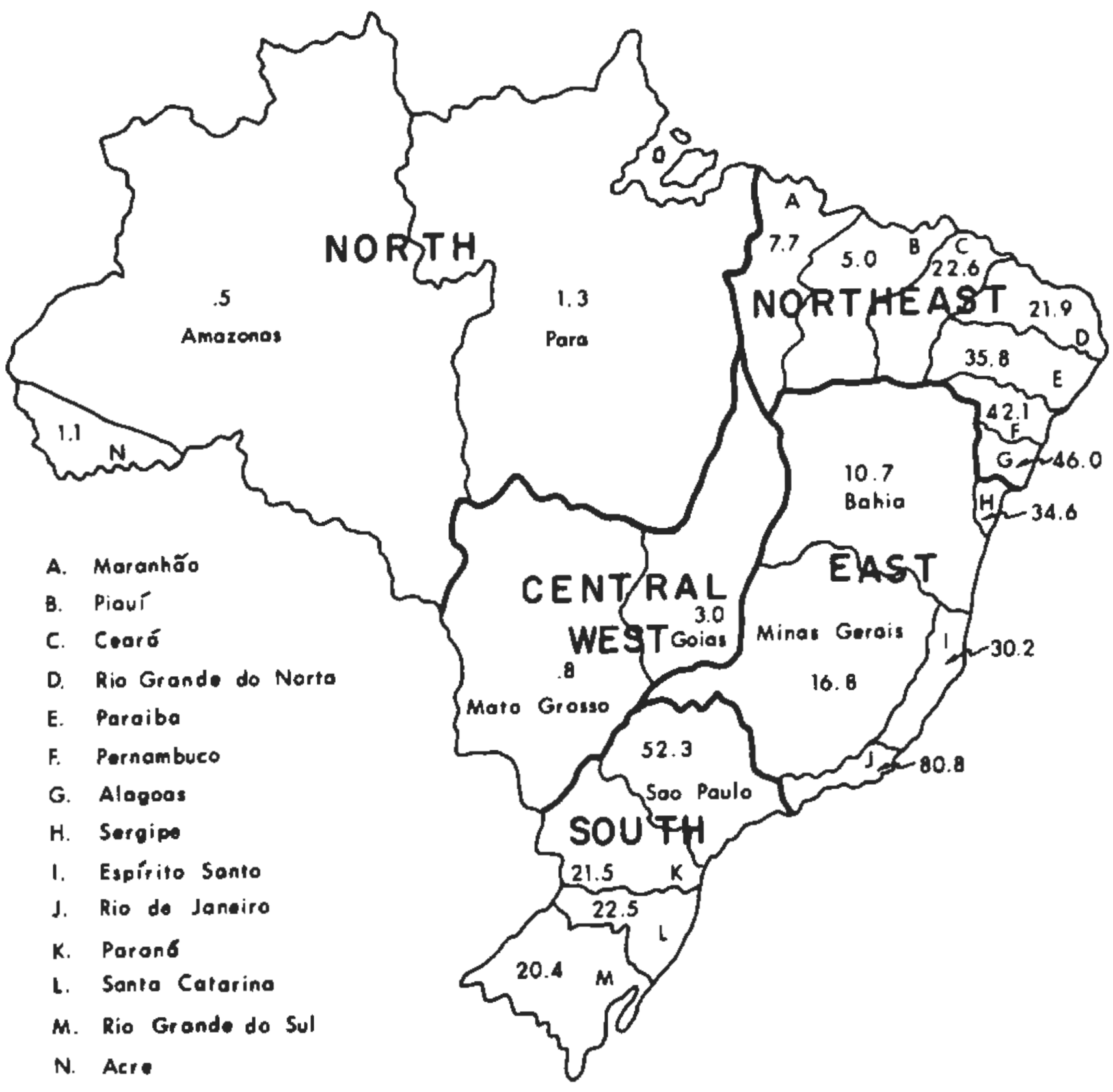

Source: Anuário Estatígtico do Brasil 1963

(Rio de Janeiro: IBGE, 1964). 


CHAPTER
OF THE
TOTAL ECONOMY

In Brazil the future and potential of the agricultural sector will in a large measure be determined by what happens in the non-farm sector and by the total set of development policies lor lack thereof) which the government follows. Consequently, we will present some background on the post-World War II development of the economy, 1 plus an assessment of current development policies and what it appears they will be in the near future.

After a quick sketch of the general economy, the remainder of the chapter is divided into five parts: (1) characteristics of recent growth, (2) inflation and the monetary situation, (3) the external sector, (4) development policies and programs, and (5) public investment.

It is important to recognize that development of the agricultural sector is very dependent on adequate labor markets to absorb the labor released when productivity is increased, strong product markets--both internally and externally--to absorb increased output, and the development of rational

economic policies by the central government. Without these, the agricultural sector will not realize the considerable potential which it has to contribute to the growth of the total economy, and any policies directed only to the development of agriculture will meet with frustration.

Brazil is a large country. It is greater in area than the continental United states and spans almost half the South American continent. The population in 1965 was estimated at 81 million, with roughly half of this classified as urban. The esestimated gross national product in 1968 was U.S. $\$ 23,218$ million. In per capita terms this was about U.S.\$260. 
The population, which between 1950 and 1960 increased at a rate of approximately 3.0 percent a year, is distributed very unevenly over the land mass, with the major fraction concentrated along the seacoast. This is a reflection of the original settling of the country, plus the failure until rather recently to develop transportation systems into the interior that integrated the country internally. Relatively high population densities are found in the poverty-stricken Northeast and in the more wellto-do South, particularly São Paulo, and the state of Rio de Janeiro.

Table 1 further details the regional population distribution. It can be seen that the major fraction of the country's population is in the East and the South. Relatively high population densities are found in the poverty-stricken Northeast, in the East, and in the more well-to-do south.

The high population density for the South reflects in large part the city of são Paulo, which had more than 4 million inhabitants in 1960. (I $\dot{t}$ is now estimated to have passed 6 million.)

The economy has been subject to a rather rapid, sustained rate of growth over a long period of time, but especially so in the decade of the 1950's. At the same time it has been subject to rather high and continuous rates of inflation.

Despite the strong performance of the economy since World War II, its growth began to lose its impetus in 1961 and came to a virtual standstill in 1963. Associated with this were a much accelerated rate of inflation in 1963 and 1964 and a political crisis, leading to a revolution on March $31,1964$. Although maintaining a semblance of democracy, the country has had a strong regime since then.

The new government has moved towards a technocratic administration and has taken large steps to rationalize economic policy. The rate of inflation has been systematically reduced by the pursuit of a consistent containment policy. Although the economy was less than buoyant in the period 1964-1967, it revived strongly in 1968 . 
TABLE 1

Regional Distribution of

Brazilian Population, 1960

(thousands)

\begin{tabular}{lcc}
\hline \multicolumn{1}{c}{ Regiona } & Population & $\begin{array}{c}\text { Density } \\
\text { (population/sq. km.) }\end{array}$ \\
\hline North & 2,602 & .73 \\
Northeast & 15,678 & 16.35 \\
East & 24,832 & 19.90 \\
South & 24,848 & 30.47 \\
Central West & 3,007 & 1.60 \\
\multicolumn{1}{c}{ Total } & 70,967 & 8.38 \\
\hline
\end{tabular}

a The geographic regions are made up of the following states: North--Amazonas, Para; Northeast-Maranhão, Piaur, Ceará, Rio Grande do Norte, Paraíba, Pernambuco, Alagoas; Central West--Mato Grosso, Goias; East--Sergipe, Bahia, Minas Gerais, Espiríto Santo, Rio de Janeiro, Guanabara; South--São Paulo, Paraná, Santa Catarina, Rio Grande do Sul.

Source: Anuário Estatístico do Brasil 1963 (Rio de Janeiro: Instituto Brasileiro de Geografía e Estatística [hereafter called IBGE], 1964, p. 27. 


\section{CHARACTERISTICS OF RECENT GROWTH}

Data on gross domestic product (GDP) trends since 1960 are presented in Table 2. After maintaining a fairly steady annual rate of growth of 6 percent in the period 1947-1961 and a rate of 7 percent between 1957 and 1961, the growth of the GDP slowed to 5.4 percent in 1962 and to 1.6 percent in 1963. Growth was fairly steady from 1964 through 1967, although substantially below the rate attained in the earlier period. Preliminary data for 1968 indicate a growth rate of 6.5 percent, which is a return to the earlier rate.

Up until 1961 the rapid rate of economic expansion had permitted an average annual increase of 3 to 4 percent in per capita output, despite a high population growth rate. In 1963, however, there was a decline in the per capita level of output. This was followed by three years of virtually no change in per capita output, although the latter increased 1.8 percent in 1967 , and apparently over 2 percent in 1968 .

The acceleration of inflation and a marked decline in the level of fixed capital formation played an important part in the economic stagnation of recent years. Especially notable was a decline in private capital formation after 1963. This led to a substantial decline in gross capital formation as a fraction of gross domestic product.

A compounding factor in the decline in aggregate economic activity was a succession of poor crop years, due in large part to poor weather. Agricultural output increased only slightly from 1962 through 1964. Because of the dependence on hydroelectric power, the dry weather in these years also affected the industrial sector.

It is interesting to note that output trends in both agriculture and industry leveled off in 1963, and that in subsequent years they tended to counterbalance each other. Restrictive monetary policies, which produced a decline in industrial output in 1965, were offset in part by a good crop year. The decline in agricultural output in 1966 , on the other hand, was offset in part by a recuperation in industrail production. 
TABLE 2

Gross Domestic Product Trends, 1960-1967

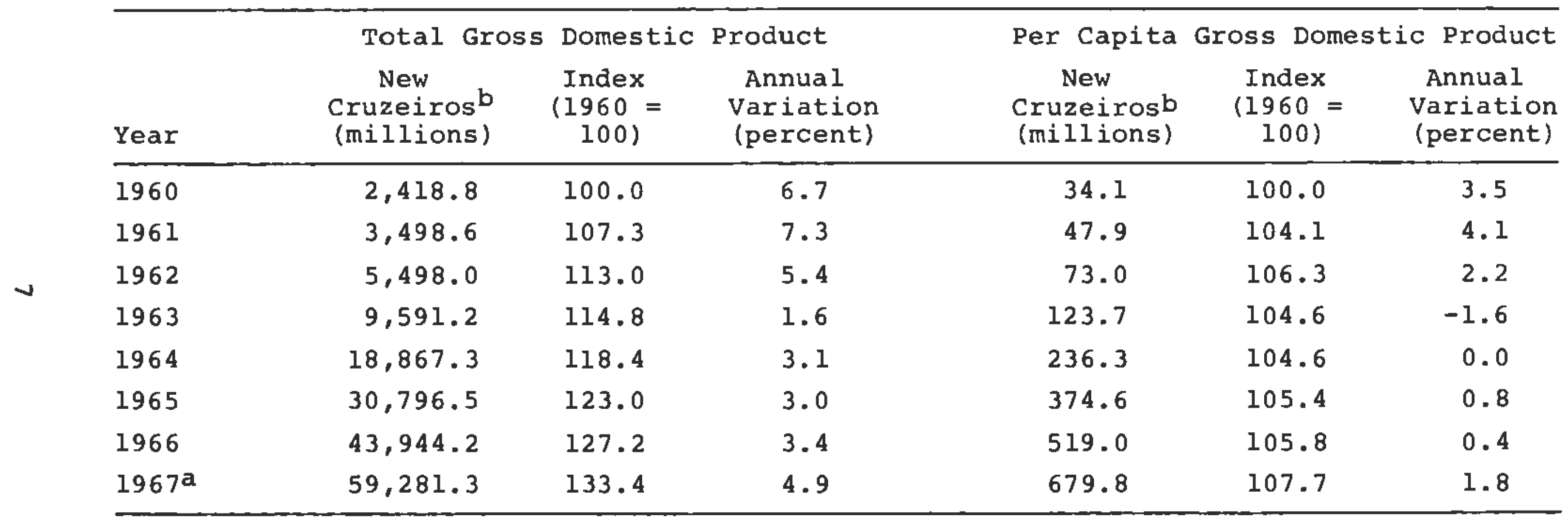

a $_{\text {Preliminary estimates. }}$

bNCr \$

Source: Fundação Getúlio Vargas (hereafter cited as FGV). 


\section{TABLE 3}

Some Macro Ratios, 1959-1966 (current prices)

\begin{tabular}{|c|c|c|c|c|c|c|c|c|}
\hline & 1959 & 1960 & 1961 & 1962 & 1963 & 1964 & 1965 & 1966 \\
\hline Government Consumption/Yr.a & 13.8 & 15.3 & 15.5 & 15.5 & 16.3 & 15.4 & 13.7 & 13.8 \\
\hline Gross Capital Formation/Yr. & 15.9 & 16.5 & 17.1 & 16.3 & 16.5 & 14.3 & 10.7 & 12.8 \\
\hline Government Capital Formation/Yr. & 4.7 & 5.2 & 4.4 & 5.7 & 4.6 & 4.8 & 5.2 & 5.0 \\
\hline Private Capital Formation/Yr. & 11.2 & 11.3 & 12.2 & 10.6 & 11.9 & 9.5 & 5.5 & 7.8 \\
\hline
\end{tabular}

a Gross domestic product.

$b_{\text {Goods }}$ and services.

Source: Computed from data of the FGV and Centro das Contas Nacionais (CCN). 
TABLE 4

Indexes of Real Product by Sectors, 1960-1967

$(1960=100)$

\begin{tabular}{lcccccccc}
\hline & 1960 & 1961 & 1962 & 1963 & 1964 & 1965 & 1966 & 19679 \\
\hline Agriculture & 100 & 107.6 & 113.5 & 114.6 & 116.1 & 132.2 & 125.0 & 134.0 \\
Industry & 100 & 110.8 & 119.3 & 120.2 & 126.2 & 120.2 & 134.4 & 138.2 \\
Commerce & 100 & 106.1 & 110.1 & 111.6 & 115.0 & 121.5 & 128.2 & 136.2 \\
Transport, Communications & 100 & 109.5 & 116.9 & 124.2 & 128.8 & 129.8 & 137.3 & 147.7 \\
Government & 100 & 102.4 & 104.8 & 107.4 & 110.0 & 112.7 & 115.4 & 118.2 \\
Services & 100 & 103.0 & 106.2 & 109.4 & 112.7 & 116.2 & 119.7 & 123.3 \\
Rents & 100 & 103.5 & $\underline{107.3}$ & $\underline{111.2}$ & $\frac{115.3}{115}$ & $\frac{119.5}{123}$ & $\frac{123.8}{127}$ & $\frac{128.2}{13}$ \\
\multicolumn{1}{c}{ Total Product } & 100 & 107.3 & 113.0 & 114.8 & 118.4 & 123.0 & 127.1 & 133.4
\end{tabular}

apreliminary estimates.

Source: FGV. 
The industrial sector provided the major impetus to Brazilian economic growth in the postwar period. 2 Data on the structure of the industrial sector are presented in Table 5 .

Measured by value added, the three largest contributors to industrial output in 1959 were food products, textiles, and ferrous metals. These three sectors also were the largest contributors in 1949, although their relative importance declined from 1949 to 1959. In 1949 the three groups represented 48.5 percent of the value added by the industrial sector, but they had declined to 39.7 percent by 1959 .

The major industry groups which were expanding during the decade include ferrous metals, chemicals, auto manufacturing, electrical and communication equipment, and heavy equipment. Perhaps the most striking increase was by the auto manufacturing sector, which increased from 2.2 percent of total value added to 7.4 percent--a more than threefold increase. (In early 1969 Brazil manufactured its two-millionth automabile.)

The employment opportunities provided by these industrial groups are similar to their value added. The three subgroups of food products, textiles, and ferrous metals provided 44.8 percent of the industrial employment in 1959. If one adds the nonferrous metal group, the total includes 54.3 percent of the total employment. The same four subgroups in 1949 provided 61 percent of the employment in the industrial sector.

That the industrial sector was providing expanding employment opportunities during the decade of the 1950's can be seen from the last column of Table 5, which shows an increase in industrial employment of 28.1 percent over the decade. However, it must be remembered that this expansion is taking place on a small base, and that the industrial sector is still a relatively small sector in relation to the total economy. The automobile industry, for example, which expanded its employment 318.2 percent in the decade, still employed only 4.2 percent of the industrial labor force by 1959 .

Moreover, it would appear that the industry groups which demand essentially unskilled labor are 
TABLE 5

Major Industrial Groups in the Brazilian Economy, 1959

\begin{tabular}{|c|c|c|c|c|c|c|c|c|}
\hline Industry & $\begin{array}{l}\text { Industrial } \\
\text { Added } \\
\text { (Cr\$1,000 } \\
1949\end{array}$ & $\begin{array}{c}1 \text { Value } \\
\text { d } \\
0.0001 \\
1959\end{array}$ & $\begin{array}{c}\text { Percentage } \\
\text { of Total } \\
\text { Industrlal } \\
\text { Output } \\
1959\end{array}$ & $\begin{array}{c}\text { Percentage } \\
\text { Change in } \\
\text { Value Added } \\
1949 / 1959\end{array}$ & $\begin{array}{l}\text { Average } \\
\text { Emplo } \\
1949\end{array}$ & $\begin{array}{l}\text { monthly } \\
\text { ment } \\
\quad 1959\end{array}$ & $\begin{array}{l}\text { Percent of } \\
\text { Total } \\
\text { Industrial } \\
\text { Employment }\end{array}$ & $\begin{array}{r}\text { Percentage } \\
\text { Change in } \\
\text { Employment } \\
1949 / 1959\end{array}$ \\
\hline Food Products & 9,760 & 89,167 & 16.2 & 811.7 & 211,948 & 217.621 & 14.4 & 2.7 \\
\hline Textiles & 9,358 & 64,576 & 11.8 & 590.1 & 313,845 & 306,122 & 20.3 & -2.5 \\
\hline Ferrous Metals & 4,469 & 63,976 & 11.7 & 1331.5 & 90,203 & 151,801 & 10.1 & 68.3 \\
\hline Chemicals & 2,540 & 46,850 & 8.5 & 1744.5 & 41,969 & 61,039 & 4.0 & 45.4 \\
\hline Auto Manufacturing & 1,062 & 40,534 & 7.4 & 3716.7 & 15,121 & 63,229 & 4.2 & 318.2 \\
\hline Non-ferrous Metals & 3,411 & 35,749 & 6.5 & 948.0 & 111,269 & 144,015 & 9.5 & 29.4 \\
\hline $\begin{array}{l}\text { Electrical, Communi- } \\
\text { cation Equipment }\end{array}$ & 763 & 20,964 & 3.8 & 2647.6 & $13,03 \mathrm{~B}$ & 44,364 & 2.9 & 240.3 \\
\hline clothing, Shoes & 2,034 & 19,227 & 3.5 & 845.2 & 64,140 & 85,263 & 5.6 & 13.3 \\
\hline Heavy Equipment & 1,018 & 18,600 & 3.4 & 1727.1 & $21,79 \mathrm{~B}$ & 49,000 & 3.2 & 122.5 \\
\hline Hood Products & 2,009 & 17,472 & 3.2 & 769.7 & 56,044 & 74,702 & 5.0 & 33.3 \\
\hline Paper, Cardboard & 1,072 & 16,419 & 3.0 & 1431.6 & 22,305 & 35,439 & 2.3 & 58.9 \\
\hline Printing & 1,899 & $16,17 \mathrm{~B}$ & 2.9 & 751.9 & 34,491 & 44,860 & 3.0 & 30.1 \\
\hline Beverages & 2,140 & 15,638 & 2.8 & 630.7 & 32,762 & 31,155 & 2.1 & -4.9 \\
\hline Pharmaceuticals & 1,336 & 13,470 & 2.4 & 908.2 & 12,489 & 13,539 & .9 & 8.4 \\
\hline Extractive Minerals & 863 & 12,214 & 2.2 & 1315.3 & 32,708 & 35,432 & 2.3 & 8.3 \\
\hline Rubber & 902 & 12,153 & 2.2 & 1247.9 & 9,137 & 14,741 & 1.0 & 61.3 \\
\hline Total & 48,644 & 548,659 & & 1027.9 & $1,177,644$ & $1,509,113$ & & 28.1 \\
\hline
\end{tabular}

Source: Anurrio Estatistico do Brasil 1963 (Rio de Janeiro: IBGE, 1964), p. 72, table 1, pt. a. 
not expanding as rapidly as those demanding higher skills. This argument would be countered somewhat if data were available on employment in the construction industry. As the economy expands, this sector also expands and provides employment opportunities for much unskilled labor. This is especially true in light of the rather strong road-building programs of recent years.

After growing steadily at an average rate of about 10 percent a year between 1947 and 1961 , and increasing its participation in the GDP from 21 to 26 percent, Brazilian industry began. to show lesser rates of growth and greater instability. This reflected all at once a relative exhaustion of the more obvious import substitution possibilities, which had provided the basis for the rapid expansion of the previous period; the slower growth rate of incomes in the agricultural sector and the economy at large in 1963 and 1964; and the acceleration of the rate of inflation, which created serious financing problems and tended to stimulate inventory accumulation instead of investment in increased capacity. ${ }^{3}$

Recent performance of the industrial sector can be seen in Table 6. Manufacturing output was especially volatile after 1962 . The rather substantial decline in 1965 was compounded by a large drop in construction activity, with the result that industrial production declined by almost 5 percent. Although the rather large increases in mining in 1963 and 1964 were helpful, they were not sufficient in 1965 to offset the declines in the other components.

These fluctuations in the industrial sector were also reflected in unemployment. Although there are no official statistics available, sample surveys made in the São Paulo area provide some information. These data indicate that registered layoffs of industrial workers with more than one year of service jumped by 72 percent in the first half of 1965 compared with the first half of 1964, and exceeded by 34 percent the number of layoffs effected during the industrial recession in the first half of 1963. 
TABLE 6

Industrial Production, Annual Changes, 1960-1967

(percent)

\begin{tabular}{|c|c|c|c|c|c|c|c|c|}
\hline & 1960 & 1961 & 1962 & 1963 & 1964 & 1965 & 1966 & 1967 \\
\hline Manufacturing & 10.6 & 11.1 & 8.1 & -0.3 & 5.1 & -4.7 & 11.2 & 2.4 \\
\hline Electrical energy & 9.2 & 6.7 & 11.3 & 2.7 & 7.2 & 4.2 & 9.4 & 4.9 \\
\hline Construction & -4.0 & 9.6 & 0.6 & 1.3 & 2.2 & -24.0 & 5.8 & 9.4 \\
\hline Mining & 17.4 & 5.9 & 1.5 & $\underline{18.4}$ & $\underline{21.9}$ & 21.4 & 7.7 & 5.6 \\
\hline Total & 10.0 & 10.8 & 7.7 & 0.2 & 5.0 & -4.9 & 11.8 & 2.9 \\
\hline Source: FGV. & & & & & & & & $\begin{array}{ll}E & \\
- & m \\
0 & 3 \\
r & \infty \\
- & 0 \\
0 & 0 \\
-1 & -1 \\
m & m \\
0 & 0 \\
0 & 0\end{array}$ \\
\hline
\end{tabular}




\section{INFLATION AND THE MONETARY SITUATION}

The Brazilian economy has been subject to high rates of inflation over a long period of time. The rate fluctuated between 8 percent and 28 percent a year during the decade of the 1950's. It started to increase in 1961, and reached a peak of 91 percent in 1964--the year of the revolution. It declined in 1965 to a rate of 57 percent, and has been declining steadily ever since. Only slight progress was made in 1968, although the government hopes to bring the rate down to 10 percent in 1969.

\section{TABLE 7}

Annual Rate of Inflation, Measured by Implicit Price Deflator, 1958-1967

\begin{tabular}{llll}
\hline 1958 & 16.2 & 1963 & 71.7 \\
1959 & 28.1 & 1964 & 90.8 \\
1960 & 25.6 & 1965 & 57.1 \\
1961 & 34.8 & 1966 & 38.0 \\
1962 & 49.2 & $1967^{a}$ & 28.6 \\
\hline
\end{tabular}

apreliminary figure.

Source: Centro das Contas Nacionais, Instituto Brasileiro de Economia, Fundação Getilio Vargas. Hereafter cited as CCN, IBRE, FGV.

The dominant line of economic policy in the period since April, 1964, has been the stabilization program. Substantial progress has been made in bringing under control the three major sources of inflationary pressures: budget deficits, bank credit, and wages.

The most striking results have been obtained in the fiscal area. Tax reforms and enforcement have led to a large increase in revenues; and this, plus more stringent control of expenditures, has led to 
a gradual reduction in the budget deficit. Moreover, greater reliance has been placed on the internal capital market through government bonds corrected for inflation. As a result, the federal government has made relatively minor demands on the monetary authorities for credit.

Wage pressures have been reduced somewhat because of the slackening of employment. The political power of the labor unions has also been reduced, which further alleviates this source of inflationary pressure.

Perhaps the most difficult political problem in controlling inflation now lies in the industrial and commercial sector. This has been the point of attack of monetary policy in recent years, and the political pressure has been great. So far the government has maintained a relatively hard line, with selective credit and tax relief used to alleviate crisis situations.

A serious drain on the national budget continues to be the companies partially and wholly owned by the government. Although a program of austerity has been instituted, the drain on the federal budget has been great, and will continue to be great until steps are taken to increase their overall efficiency. 4

As a result of the austerity measures instituted in 1964, it was hoped to hold transportation subsidies constant in money terms, which would have been a decline in real terms. In fact, their share of the budget, which was as high as 19 percent in 1963, dropped to 14 percent in 1964, and about 12 pércent in 1965.

Detail on the subsidies to the transportation sector can be seen in Table 8 . The federal railways receive the heaviest operating subsidies, although the subsidy to shipping increased substantially in 1965 .

Despite these steps towards more rational monetary and fiscal policies, many problems remain. The political pressures against the containment policies have indeed been great. The shift in asset holdings which is involved in de-escalating from an almost institutionalized rate of inflation imposes serious capital losses on asset owners. And the absence of 
TABLE 8

Federal Government Operating Subsidies to Transport, 1960-1965

\begin{tabular}{|c|c|c|c|c|c|c|}
\hline & \multirow[b]{2}{*}{ Railways } & \multirow[b]{2}{*}{$\begin{array}{l}\text { Shipping } \\
\text { (million }\end{array}$} & \multirow[b]{2}{*}{$\begin{array}{l}\text { Ports } \\
\text { NCr\$) }\end{array}$} & \multirow[b]{2}{*}{ Aviation } & \multicolumn{2}{|c|}{ Total } \\
\hline & & & & & $\begin{array}{l}\text { Mil1ion } \\
\text { (NCr\$) }\end{array}$ & $\begin{array}{l}\text { Percent of } \\
\text { Total } \\
\text { Budget } \\
\text { Spending }\end{array}$ \\
\hline 1960 & 19 & 10 & - & 1 & 30 & 11.5 \\
\hline 1961 & 40 & 22 & 1 & 3 & 65 & 15.5 \\
\hline 1962 & 84 & 28 & 5 & 12 & 128 & 17.7 \\
\hline 1963 & 179 & 46 & 6 & 12 & 243 & 19.0 \\
\hline 1964 & 280 & 61 & 25 & 18 & 384 & 13.9 \\
\hline 1965 & 290 & 115 & 62 & 25 & 492 & 11.8 \\
\hline
\end{tabular}

Source: Presidential message to Congress on draft budget for 1966. 
fixed annuity owners means that there are few vested interests opposing inflation.

In addition, the development of an adequate private capital market is a serious need, for both the agricultural and non-agricultural sectors. New legislation has been passed to this end, and success in the containment policy should help.

\section{THE EXTERNAL SECTOR}

During the 1950 's Brazilian exports virtually stagnated. This was due largely to the behavior of non-coffee exports--the so-called "minor products": cocoa, cotton, tobacco, sugar, hides, rubber, timber, iron ore, meat, and other primary products. This decline in the value of Brazil's non-coffee contrasts sharply with the export performance of other countries, for world trade in these products grew at an annual average rate of approximately 3.1 percent during this period.

The stagnation in exports was not due to a high level of Brazilian costs, but rather to the government policy towards exports.5 The response to the recurring balance of payments problems in the postWorld War II period was an intensive import-substitution industrialization program. This program was viewed both as a basis for the domestic development program and as a means of reducing the external imbalance. Associated with this was a view that a country should export only what is "left over" after the domestic market has been satisfied.

The idea of deliberately concentrating output in specialized production for the export market, or of permitting output to be allocated between the domestic and overseas markets by means of the price mechanism, so that higher consumption might be attained in other products (in which Brazil was relatively less efficient), does not seem to have been given serious consideration as a viable policy. Rather, a "vent for surplus" approach to trade was applied to all non-coffee exports.

A primary instrument in implementing this policy was the licensing of all non-coffee exports. This was handled through a specialized government 
agency, and the decision rule followed was that a license was not granted so long as the domestic price of the product was rising in absolute terms. With the relatively high rates of domestic inflation, the application of this rule resulted in a substantial diversion of potential exports to the domestic market.

This negative approach towards the potential gains of specialization, and the possibility of acquiring other goods more cheaply through international trade than through domestic production, was responsible for other measures hindering exports. For example, during much of the period the exchange rate was grossly overvalued and was pegged for substantial periods of time. An overvalued exchange rate has been one of the principal policy instruments in the effort at maximization of foreign exchange earnings from coffee. From this standpoint, there was some basis for it. Unfortunately, however, the overvalued exchange rate was extended to primary products in which Brazil did not have a dominant world market.

The consequence of forcing virtually all of the adjustment process onto import substitution, and the gradual exhaustion of import-substitution possibilities, was a series of balance of payments crises in the early $1960^{\prime} \mathrm{s}$. This problem was especially severe in view of the rather large amount of shortterm debt that needed servicing.

Since 1964, however, foreign trade policy has gradually shifted to one of export promotion. Licensing requirements have been eliminated, and efforts have been made to move the exchange rate closer to the equilibrium level. In late 1968 a policy of making small monthly devaluations was started.

Brazil's balance of payments situation improved considerably in 1964 and 1965, Owing, in particular, to an improvement in the current account. The latter became positive for the first time in eight years and should be compared with deficits of $\$ 200$ million to $\$ 500 \mathrm{million}$ in the early $1960 \mathrm{\prime}$. The autonomous inflow of capital, on the other hand, continued to decline through 1966, despite the efforts of the government to create a more favorable climate for foreign capital. 
Tho current account improvement reflected, ossentially, a sharp increase in the trade balance in 1964 and ita maintenance at a high level in 1965. This resulted in large part from a major readjustment in tho lovel of imports, which fell by 20 percent in 1964, and even further in 1965. Export carnings, on the other hand, have been expanding as non-traditional exports have grown. The fruition of the new policies came in 1968, when exports increased very substantially.

The major factor in the improvement in the trade balance was the adoption of a more realistic exchange policy, although the decline in aggregate demand resulting from the domestic containment policy helped somewhat in reducing imports. The devaluation of the cruzeiro ralsed the foreign exchange rate by about 200 percent in the course of 1964. A series of periodic devaluations, made in the following three years, gradually moved the exchange rate toward equilibrium.

If Brazil's development programs are successful, balance of payments problems are likely to be a continuing problem. The need to expand exports at an increasing rate will be great. The liberalization of foreign trade policy presents important opportunities to the agricultural gector; and especially in non-traditional products, Brazil has the potential to realize substantial exchange earnings from its agricultural resources.

\section{DEVELOPMENT POLICIES AND PROGRAMS}

Brazil does not have a development plan. However, since 1964 it has been implementing a coherent and comprehensive set of economic policies designed to re-activate economic growth while slowing inflation.6 The program, which calls for a substantial increase in fixed capital formation, $1 \mathrm{~s}$ founded on a public sector investment program. To execute this program without precipitating gerious financial disequilibrium, the federal government 18 adopting tax and expenditure policies which have already permitted a sharp increase in public sector savings. The external contribution to the investment program so far has not been large, although it has been applied in such a way as to ensure overall financial balance of the public sector. 
The goal of the development program is a GDP growth rate equal to the average experienced in the 1947-1961 period-i.e., about 6 percent per year-and a subsequent increase in this rate to the level reached in 1957-1961, when expansion accelerated to an average of nearly 7 percent annually. With a population increase of approximately 3 percent a year, a 6 percent annual increase in the total product would mean an annual rise of about 3 percent in per capita product. This would eventually be stepped up to roughly 4 percent per year when the overall growth rate was accelerated to 7 percent.

These rates are entirely consistent with past rates of economic growth in the country. Although recuperation from the decline in per capita income in 1963 has been slow, largely as a result of the large adjustment necessary to eliminate previous distortions and the shock involved in the antiinflationary policy, the results for 1967 and 1968 are encouraging.

The program envisages a shift in emphasis between the agricultural and industrial sectors. The target for the agricultural sector in the coming years is an increase from the 4.5 percent average growth rate of 1947-1961 to a rate of 5.6 percent annually. Industry, on the other hand, is expected to grow somewhat more slowly than it did in the earlier period.

A concerted attempt is also being made to attract extemal private capital. The results from this program were slow at first, but in the latter half of 1965 and during 1966 the inflow was more encouraging. The entrance of foreign capital has now reached a point where it represents a problem of concern in the local press and among lay people.

\section{PUBLIC INVESTMENT}

The rapid growth of the 1947-1961 period did not require a particularly high investment ratioan average of 16.5 percent of the GDP with gross fixed capital formation averaging 15 percent of the GDP and inventory accumulation 1.5 percent. The official program of the government contemplates a rate of fixed capital formation equal to 17 percent 
of the GDP, which represents an increase of 2 percent over the 1947-1961 average, and a jump of 3-4 percent over the depressed fixed investment ratio that is estimated to have prevailed in 1961-1963 as the result of a sharp decline in both domestic and foreign private interest.

The effect of the 17 percent rate of fixed capital formation on consumption will depend on the contribution of external resources (as measured by the current account deficit of the balance of payments). In 1947-1961 this contribution was small, averaging less than 1 percent of the GDP for the period as a whole. In 1961-1963 it rose to 2-4 percent of the GDP as the high inflation depressed the gross domestic savings rate. In 1964 and 1965 , on the other hand, there was a net surplus of exports of goods and services.

Brazil is probably at a stage where development can be financed largely from domestic resources, with little or no net contribution of external capital. However, large gross inflows will be required to offset service payments on external debts, and hence the need to export will be great. Here the agricultural sector has a great deal of potential.

Significant changes are taking place in the pattern and role of public investment. This represents a trend that has been taking place over a period of years. For about 10 years after World War II the share of public investment in the GDP remained at about 4 percent. After 1956 it rose to about 6 percent, while private investment was falling off to somewhat over 7 percent. The breakdown between public and private investment in the entire postwar period is shown in Table 11.

This shift in favor of public investment is likely to persist since the government is launching a large-scale public investment program in every major sector of the economy. This program ranges from the transport and power infrastructure to the basic industries of petroleum and steel, agriculture, and the development of education, health, and housing facilities.

Major emphasis in this public investment program will be given to expanding the transport network and to increasing the capacity of the electric 
TABLE 9

Fixed Capital Formation, Change in Stocks, Balance of Payments, Gross Domestic Product, 1947-1966

(million NCr\$)

\begin{tabular}{|c|c|c|c|c|}
\hline Year & $\begin{array}{c}\text { Fixed } \\
\text { Capital } \\
\text { Formation }\end{array}$ & $\begin{array}{l}\text { Change } \\
\text { in } \\
\text { stocks }\end{array}$ & $\begin{array}{l}\text { Balance } \\
\text { of } \\
\text { Payments }\end{array}$ & $\begin{array}{l}\text { Gross } \\
\text { Domestic } \\
\text { Product }\end{array}$ \\
\hline $\begin{array}{l}1947 \\
1948 \\
1949\end{array}$ & $\begin{array}{l}28.4 \\
30.0 \\
32.3\end{array}$ & $\begin{array}{l}-2.8 \\
-.7 \\
-4.1\end{array}$ & $\begin{array}{r}3.1 \\
.8 \\
2.2\end{array}$ & $\begin{array}{l}164.3 \\
186.8 \\
215.6\end{array}$ \\
\hline $\begin{array}{l}1950 \\
1951 \\
1952 \\
1953 \\
1954\end{array}$ & $\begin{array}{l}33.6 \\
49.2 \\
54.4 \\
55.8 \\
91.4\end{array}$ & $\begin{array}{r}-4.7 \\
8.6 \\
11.8 \\
2.6 \\
19.0\end{array}$ & $\begin{array}{r}1.9 \\
8.7 \\
13.2 \\
-\quad .6 \\
6.7\end{array}$ & $\begin{array}{l}253.3 \\
306.1 \\
352.1 \\
430.7 \\
558.2\end{array}$ \\
\hline $\begin{array}{l}1955 \\
1956 \\
1957 \\
1958 \\
1959\end{array}$ & $\begin{array}{r}99.2 \\
117.0 \\
137.9 \\
181.0 \\
288.0\end{array}$ & $\begin{array}{r}8.8 \\
13.7 \\
22.5 \\
-.2 \\
17.0\end{array}$ & $\begin{array}{r}1.0 \\
-\quad .7 \\
14.2 \\
18.0 \\
33.2\end{array}$ & $\begin{array}{r}695.1 \\
887.2 \\
1,059.8 \\
1,313.6 \\
1,806.0\end{array}$ \\
\hline $\begin{array}{l}1960 \\
1961 \\
1962 \\
1963 \\
1964\end{array}$ & $\begin{array}{r}399.7 \\
600.2 \\
893.7 \\
1.579 .9 \\
2,696.5\end{array}$ & $\begin{array}{r}18.8 \\
48.5 \\
106.4 \\
100.2 \\
410.0\end{array}$ & $\begin{array}{r}58.0 \\
45.6 \\
169.6 \\
126.5 \\
-95.2\end{array}$ & $\begin{array}{r}2,418.8 \\
3,498.6 \\
5,498.0 \\
9,591.2 \\
18,867.3\end{array}$ \\
\hline $\begin{array}{l}1965 \\
1966\end{array}$ & $\begin{array}{l}3,298.8 \\
5,668.6\end{array}$ & -- & $\begin{array}{r}-528.5 \\
52.8\end{array}$ & $\begin{array}{l}30,796.5 \\
44,369.1\end{array}$ \\
\hline
\end{tabular}

Source: CCN, IBRE, FGV. 
TABLE 10

Public and Private Investment in Gross Domestic Product, 1956-1964 (percent)

\begin{tabular}{lccccccccc}
\hline & 1956 & 1957 & 1958 & 1959 & 1960 & 1961 & 1962 & 1963 & 1964 \\
\hline $\begin{array}{l}\text { Federal Government } \\
\begin{array}{l}\text { State and Local } \\
\text { Governments }\end{array}\end{array}$ & 2.1 & 3.6 & 3.8 & 3.6 & 3.8 & 4.0 & 4.0 & 4.8 & 3.8 \\
$\begin{array}{l}\text { Total Government } \\
\text { Private }\end{array}$ & 3.7 & 5.5 & 6.2 & 5.4 & 6.1 & 6.2 & 6.2 & 6.9 & 5.9 \\
$\begin{array}{l}\text { Gross Fixed Capital } \\
\text { Formation }\end{array}$ & 13.5 & $\underline{7.5}$ & $\underline{7.6}$ & $\underline{10.7}$ & $\underline{8.8}$ & $\underline{7.5}$ & $\underline{7.5}$ & $\underline{6.6}$ & $\ldots$ \\
$\quad$ & 13.2 & 13.0 & 13.8 & 16.1 & 14.9 & 13.7 & 13.7 & 13.5 & $\ldots$ \\
\hline
\end{tabular}

Source: International Bank for Reconstruction and Development (IBRD). 
TABLE 11

Public, Private, and Total Investment, 1947-1966 (million NCr\$)

\begin{tabular}{|c|c|c|c|c|c|}
\hline Year & Public & Private & Total & $\begin{array}{c}\text { Public as } \\
\text { Percent } \\
\text { of Total } \\
\end{array}$ & $\begin{array}{c}\text { Private as } \\
\text { Percent of } \\
\text { Total } \\
\end{array}$ \\
\hline $\begin{array}{l}1947 \\
1948 \\
1949\end{array}$ & $\begin{array}{l}4.5 \\
7.0 \\
9.5\end{array}$ & $\begin{array}{l}23.9 \\
23.0 \\
22.8\end{array}$ & $\begin{array}{l}28.4 \\
30.0 \\
32.3\end{array}$ & $\begin{array}{l}15.8 \\
23.3 \\
29.4\end{array}$ & $\begin{array}{l}84.2 \\
76.7 \\
70.6\end{array}$ \\
\hline $\begin{array}{l}1950 \\
1951 \\
1952 \\
1953 \\
1954\end{array}$ & $\begin{array}{l}11.7 \\
12.1 \\
14.3 \\
15.1 \\
20.8\end{array}$ & $\begin{array}{l}21.9 \\
37.1 \\
40.1 \\
40.7 \\
70.6\end{array}$ & $\begin{array}{l}33.6 \\
49.2 \\
54.4 \\
55.8 \\
91.4\end{array}$ & $\begin{array}{l}34.8 \\
24.6 \\
26.3 \\
27.1 \\
22.8\end{array}$ & $\begin{array}{l}65.2 \\
75.4 \\
73.7 \\
72.9 \\
77.2\end{array}$ \\
\hline $\begin{array}{l}1955 \\
1956 \\
1957 \\
1958 \\
1959\end{array}$ & $\begin{array}{l}22.3 \\
26.8 \\
47.4 \\
68.5 \\
85.5\end{array}$ & $\begin{array}{r}76.9 \\
90.2 \\
90.5 \\
112.5 \\
202.5\end{array}$ & $\begin{array}{r}99.2 \\
117.0 \\
137.9 \\
181.0 \\
288.0\end{array}$ & $\begin{array}{l}22.5 \\
22.9 \\
34.4 \\
37.8 \\
29.7\end{array}$ & $\begin{array}{l}77.5 \\
77.1 \\
65.6 \\
62.2 \\
70.3\end{array}$ \\
\hline $\begin{array}{l}1960 \\
1961 \\
1962 \\
1963 \\
1964\end{array}$ & $\begin{array}{l}126.5 \\
170.6 \\
313.6 \\
440.3 \\
903.6\end{array}$ & $\begin{array}{r}273.2 \\
429.6 \\
580.1 \\
1139.6 \\
1792.9\end{array}$ & $\begin{array}{r}399.7 \\
600.2 \\
893.7 \\
1579.9 \\
2696.5\end{array}$ & $\begin{array}{l}31.6 \\
28.4 \\
35.1 \\
27.9 \\
33.5\end{array}$ & $\begin{array}{l}68.4 \\
71.6 \\
64.9 \\
72.1 \\
66.5\end{array}$ \\
\hline $\begin{array}{l}1965 \\
1966\end{array}$ & $\begin{array}{l}1601.4 \\
2237.6\end{array}$ & $\begin{array}{l}1697.4 \\
3431.0\end{array}$ & $\begin{array}{l}3298.8 \\
5668.6\end{array}$ & $\begin{array}{l}48.6 \\
39.5\end{array}$ & $\begin{array}{l}51.4 \\
60.5\end{array}$ \\
\hline
\end{tabular}

Source: CCN, IBRE, FGV. 
power and petroleum industries. These three sectors taken together account for about 55 percent of the total investment scheduled for the public sector as a whole, and nearly 60 percent of the investment planned for the federal government proper. The largest investment within the transport sector is in roads and highway construction and improvement. This is being carried out by all levels of government.

Agriculture was to receive about 5 percent of the total investment planned, to a large extent in the form of public financing for private investment. Agriculture benefits indirectly from other programs, such as highway construction and port improvement, and it should be remembered that the flow account of the state and national budgets would provide additional amounts to agriculture. A major effort is also being expended on education, although the performance in this sector is by most standards still inadequate.

NOTES

1. For an analysis of postwar development, see Werner Baer, Industrialization and Economic Development in Brazil (Homewood, Ill.: Richard D. Irwin, Inc., 1965).

2. For a rather detailed analysis of the industrial sector, see A Industrialização Brasileira: Diagnóstico e Perspectivos, "Documentos IPEA," No. 4 TRio de Janeiro: Instituto de Pesquisas Económicas Aplicadas (IPEA), Ministério do Planejamento e Coordenação Geral, 1968).

3. For a summary of the alternative interpretations of the "stagnation" of the general economy in this period, see Werner Baer and Andrea Maneschi, "Import-Substitution, Stagnation and Structural Change, an Interpretation of the Brazilian Case" (Vanderbilt University, 1969). (Mimeographed.)

4. For a critique of government ownership of the transportation system in Brazil, see clarence $J$. Miller and John R. Felton, "A Critique of Government ownership and operation of surface Media in Brazil," 
Transportation Research Forum, Seventh Annual Meeting (1966), "Papers"; Werner Baer, Isaac Kers tenetsky, and Mario H. Simonsen, "Transportation and Inflation: A Study of Irrational Policy Making in Brazil," Economic Development and Cultural Change (January, 1965).

5. For a more detailed analysis, see Nathaniel H. Leff, "Export Stagnation and Autarkic Development, "Quarterly Journal of Economics, LXXXI (May, 1967), $286-301$.

6. For the most recent development program, see Programa Estratégico de Desenvolvimento, 19681970 (Rio de Janeiro: Ministério do Planejamento e Coordenação Geral, 1968). A comprehensive review of planning in Brazil can be found in Robert $T$. Daland, Brazilian Planning, Development Politics and Administration (Chapel Hill: University of North Carolina Press, 1967). 


CHAPTER
POPULATION,
MIGRATION, AND
THE LABOR MARKET

The rate of population growth and its geographic distribution have important implications for agriculture and its organization. In addition, the performance of the labor market is an important determinant of the well-being of farm people. It is to these issues that we now turn.

The chapter is organized in three main parts. The first section provides data on the size of the population, its rate of growth, and its geographic distribution. The second part provides data on the migratory processes within the country. The third section makes an analysis of the national labor market and the extent to which it is handling its allocatory function in a satisfactory manner.

\author{
THE POPULATION AND ITS \\ GEOGRAPHIC DISTRIBUTION 1
}

Population growth since 1940 is shown in Table 12. The estimated population as of 1965 was 81 million, and projections to 1970 predict a population of over 95 million.

In the decades of the 1920's and $1930^{\prime} \mathrm{s}$, population was growing at a relatively constant geometric rate of 1.5 percent per year. In the decade of the $1940^{\prime} \mathrm{s}$, this increased to 2.3 percent per year, and in the 1950 's to 3.0 percent. Little or no reduction in this growth rate is foreseen in the near future, although a change in attitudes towards birth control could of course reduce it in a fairly short time. 
TABLE 12

Population Growth, 1940-1970 (Projected)

\begin{tabular}{lcc}
\hline Year & $\begin{array}{c}\text { Population } \\
\text { (millions) }\end{array}$ & $\begin{array}{c}\text { Percent Increase over } \\
\text { Previous Census }\end{array}$ \\
\hline 1940 & 41.2 & -- \\
1950 & 51.9 & 26 \\
1960 & 70.1 & 35 \\
1970 & 95.1 & 36 \\
\hline
\end{tabular}

Source: Projections of Supply and Demand for Agricultural products of Brazil (Rio de Janeiro: FGV, 1967).

One of the consequences of this rapidly growing population is that the age distribution is skewed to the right. In 1960, for example, 53 percent of the population was 19 years of age or younger. In rural areas it was 56 percent. The fraction of the population that was nine years or less was 32 percent in 1960. The implications of this age distribution in terms of the potential work force available and the education problem are quite important. It is likely to be a continuing problem.

The Brazilian population is highly concentrated geographically. There are two aspects to this concentration. First, it tends to be concentrated almost completely in three of the five census regions. Second, it tends to be highly concentrated along the Atlantic littoral.

Ninety-two percent of the total, 96 percent of the urban, and 91 percent of the rural population live in the Northeast, the East, and the South, leaving the North and Central West still sparsely settled or largely unsettled. The first three regions occupy only a little over one-third of the country. Hence, their population density is about 20 times higher, on the average, than that of the two remaining regions. 
Distribution and Density of Population, by Region, 1960

\begin{tabular}{|c|c|c|c|c|}
\hline \multirow{2}{*}{$\frac{\text { Region }}{\text { Northeast }}$} & \multirow{2}{*}{$\frac{\begin{array}{c}\text { Area } \\
\text { (million } \\
\text { sq.km.) }\end{array}}{.96}$} & \multicolumn{2}{|c|}{$\begin{array}{l}\text { Population } \\
\text { Total Rural } \\
\text { (millions) }\end{array}$} & \multirow{2}{*}{$\begin{array}{c}\begin{array}{c}\text { Total } \\
\text { Density } \\
\text { (Persons/ } \\
\text { sq.km.) }\end{array} \\
16.4\end{array}$} \\
\hline & & 15.7 & 10.4 & \\
\hline East & 1.26 & 24.8 & 12.8 & 19.7 \\
\hline South & .81 & $\underline{24.8}$ & 12.2 & 30.7 \\
\hline Subtotal & 3.03 & 65.3 & 35.4 & 21.6 \\
\hline North & 3.55 & 2.6 & 1.6 & .7 \\
\hline Central West & 1.88 & 3.0 & 2.0 & 1.6 \\
\hline Subtotal & 5.43 & 5.6 & 3.6 & 1.0 \\
\hline Total & 8.46 & 71.0 & 39.0 & 8.4 \\
\hline
\end{tabular}

Note: Small discrepancies due to rounding.

Source: IBGE; Land Tenure Conditions and Socio-Economic Development of the Agricultural Sector, (Washington, D.C.: Comitê Interamericano de Desenvolvimento Agricola, Pan American Union, 1966). (Hereafter cited as CIDA Report.) 
The North and Central West have large areas of land with agricultural potential. Some of the soils are types about which very little is known, such as the cerrados, but others can be tilled with little or no knowledge. Migration is taking place into these regions at a rapid rate, especially into the states of Goifs and Mato Grosso in the Central West and Pars in the North. Full development of these regions, however, will require very large investments in infrastructure.

The accumulation of people along the coast or littoral area can be seen in Table 14. Note that in 1960,48 percent of the population lived in the 13 percent of the country which borders on the Atlantic Ocean--in what is called (by the census) littoral areas. This is a population density of about 31 persons per square kilometer. Moreover, about 47 percent of the population lived in the coastal areas of the three most densely populated central regions, which make up about 9 percent of the whole country. Here the population density was equivalent to about 42 persons per square kilometer. Thus the population density is on the average nearly four times higher in the small strip along the coast than in Brazil as a whole, or six times higher than in "non-littoral" Brazil.

A high internal migration, which will be discussed more fully later, is resulting in a much higher rate of population increase in the South than in the remainder of the country. of the 7.8 million people added to the population of the south in the decade of the $1950^{\prime} \mathrm{s}$, São Paulo alone accounted for $3.9 \mathrm{million}$ and the rapidly expanding state of Parana for 2.2 million. As a rough approximation, 1.5 of the $7.8 \mathrm{million}$ can be accounted for by immigrants, of whom about 500,000 went into são Paulo and 800,000 into Parana. $2^{\circ}$

\section{MIGRATION}

Brazil has historically had a rather mobile labor force. Workers have followed expanding employment opportunities, be they in the sugar industry in the North during the 17th century, the "rush" to 


\section{TABLE 14}

Concentration of Population in Littoral Areas, a 1960

\begin{tabular}{|c|c|c|c|c|c|}
\hline Region & $\begin{array}{c}\text { Area in } \\
\text { Littoral } \\
\text { (million } \\
\text { sq.km.) }\end{array}$ & $\begin{array}{l}\text { Percent } \\
\text { Littoral } \\
\text { Area of } \\
\text { Region }\end{array}$ & $\begin{array}{c}\text { Population } \\
\text { in } \\
\text { Littoral } \\
\text { Area } \\
\text { (millions) }\end{array}$ & $\begin{array}{c}\text { Percent } \\
\text { Population } \\
\text { in Littoral } \\
\text { Areas of } \\
\text { Total in } \\
\text { Region }\end{array}$ & $\begin{array}{c}\text { Density } \\
\text { in } \\
\text { Littoral } \\
\text { Area }\end{array}$ \\
\hline Northeast & .2 & 20 & 7.9 & 50 & 40.8 \\
\hline East & .2 & 20 & 11.5 & 46 & 46.2 \\
\hline South & .3 & $\underline{42}$ & 13.7 & 55 & 40.7 \\
\hline Subtotal & .8 & 26 & 33.1 & 51 & 42.4 \\
\hline North & .3 & 9 & 1.1 & 42 & 3.4 \\
\hline Total & 1.1 & 13 & 34.2 & 48 & 31.1 \\
\hline
\end{tabular}

a"Littoral" as defined by the census. The Central West does not border on the ocean.

Source: IBGE; CIDA Report. 


\section{TABLE 15}

Population Distribution by Region, 1950 and 1960

\begin{tabular}{|c|c|c|c|c|c|c|}
\hline Region & $\begin{array}{l}\text { Tot } \\
1950\end{array}$ & al & \multicolumn{2}{|c|}{$\begin{array}{l}\text { Urban } \\
19501960 \\
\text { (millions) }\end{array}$} & $\begin{array}{r}\text { Rur } \\
1950\end{array}$ & $\stackrel{\text { al }}{1960}$ \\
\hline $\begin{array}{l}\text { Northeast } \\
\text { East } \\
\text { South } \\
\quad \text { Subtotal }\end{array}$ & $\begin{array}{l}12.5 \\
18.9 \\
17.0 \\
48.4\end{array}$ & $\begin{array}{l}15.7 \\
24.8 \\
24.8 \\
65.3\end{array}$ & $\begin{array}{r}3.3 \\
7.4 \\
7.1 \\
17.8\end{array}$ & $\begin{array}{r}5.3 \\
12.0 \\
12.6 \\
29.9\end{array}$ & $\begin{array}{r}9.2 \\
11.5 \\
9.9 \\
30.6\end{array}$ & $\begin{array}{l}10.4 \\
12.8 \\
12.2 \\
35.4\end{array}$ \\
\hline $\begin{array}{l}\text { North } \\
\text { Central West } \\
\text { Subtotal }\end{array}$ & $\begin{array}{l}1.8 \\
1.7 \\
3.5\end{array}$ & $\begin{array}{l}2.6 \\
3.0 \\
5.6\end{array}$ & $\begin{array}{r}.6 \\
.4 \\
1.0\end{array}$ & $\begin{array}{l}1.0 \\
1.1 \\
2.1\end{array}$ & $\begin{array}{l}1.3 \\
1.3 \\
2.6\end{array}$ & $\begin{array}{l}1.6 \\
2.0 \\
3.6\end{array}$ \\
\hline \multirow[t]{2}{*}{ Total } & 51.9 & 71.0 & 18.8 & 32.0 & 33.2 & 39.0 \\
\hline & \multicolumn{6}{|c|}{ (percent) } \\
\hline $\begin{array}{l}\text { Northeast } \\
\text { East } \\
\text { South } \\
\quad \text { Subtotal }\end{array}$ & $\begin{array}{l}24 \\
36 \\
33 \\
93\end{array}$ & $\begin{array}{l}22 \\
35 \\
35 \\
92\end{array}$ & $\begin{array}{l}18 \\
39 \\
38 \\
95\end{array}$ & $\begin{array}{l}17 \\
38 \\
39 \\
94\end{array}$ & $\begin{array}{l}27 \\
35 \\
30 \\
92\end{array}$ & $\begin{array}{l}27 \\
33 \\
31 \\
91\end{array}$ \\
\hline $\begin{array}{l}\text { North } \\
\text { Central. West } \\
\text { Subtotal }\end{array}$ & $\begin{array}{r}4 \\
3 \\
7\end{array}$ & $\begin{array}{l}4 \\
4 \\
8\end{array}$ & $\begin{array}{l}3 \\
2 \\
5\end{array}$ & $\begin{array}{l}3 \\
\frac{3}{6}\end{array}$ & $\begin{array}{l}4 \\
4 \\
8\end{array}$ & $\begin{array}{l}4 \\
5 \\
9\end{array}$ \\
\hline Total & 100 & 100 & 100 & 100 & 100 & 100 \\
\hline
\end{tabular}

Source: IBGE; CIDA Report. 
mine gold in Minas Gerais at a later date, or the expansion of the industrial sector in São Paulo in the post-World War Ir period. 3

Data limitations have precluded a systematic analysis of the migratory process in Brazil, even though the importance of the phenomenon is generally recognized. 4 In this section an attempt is made to piece together from existing data some notion of the migration processes in the postwar period. The analysis has serious limitations because of the lack of data, and the result can in no way be assumed to be a precise picture. The lack of basic data to make estimates of migration, and the unavailability of the still uncompleted 1960 demographic census seriously handicap a rigorous analysis. The rather gross data are instructive on the gross population shifts, however, and when combined with data presented in the-next section, suggest that Brazil has serious labor market problems which merit imuediate attention.

Our interest in this section focuses on two aspects of the population shifts: (1) the geographic shifts within the country and (2) the rural-urban flow. These are not unrelated, of course, but data limitations preclude a complete disentangling of the two.

\section{Geographic Shifts}

Data on internal migration are available only for the period 1940-1950. The censuses in these two years contained questions which attempted to identify the place of birth of the population. This leads to estimates of the number of "foreign-born" in a state of interest and the number of native-born outside the state of interest for the two census years. These basic data, plus population estimates by states for 1940 and 1950, are presented in Table 16 .

From these data two useful data series can be constructed which provide insights into the migration process. The first is obtained by taking the number of foreign-born in the state of interest and subtracting from it the number of native-born outside the state of interest. The resulting concept indicates in a crude way whether the state has been a net gainer of population through migration or 
TABLE 16

Population by state and Region, 1940 and 1950, and Internal Migration, 1940-1950

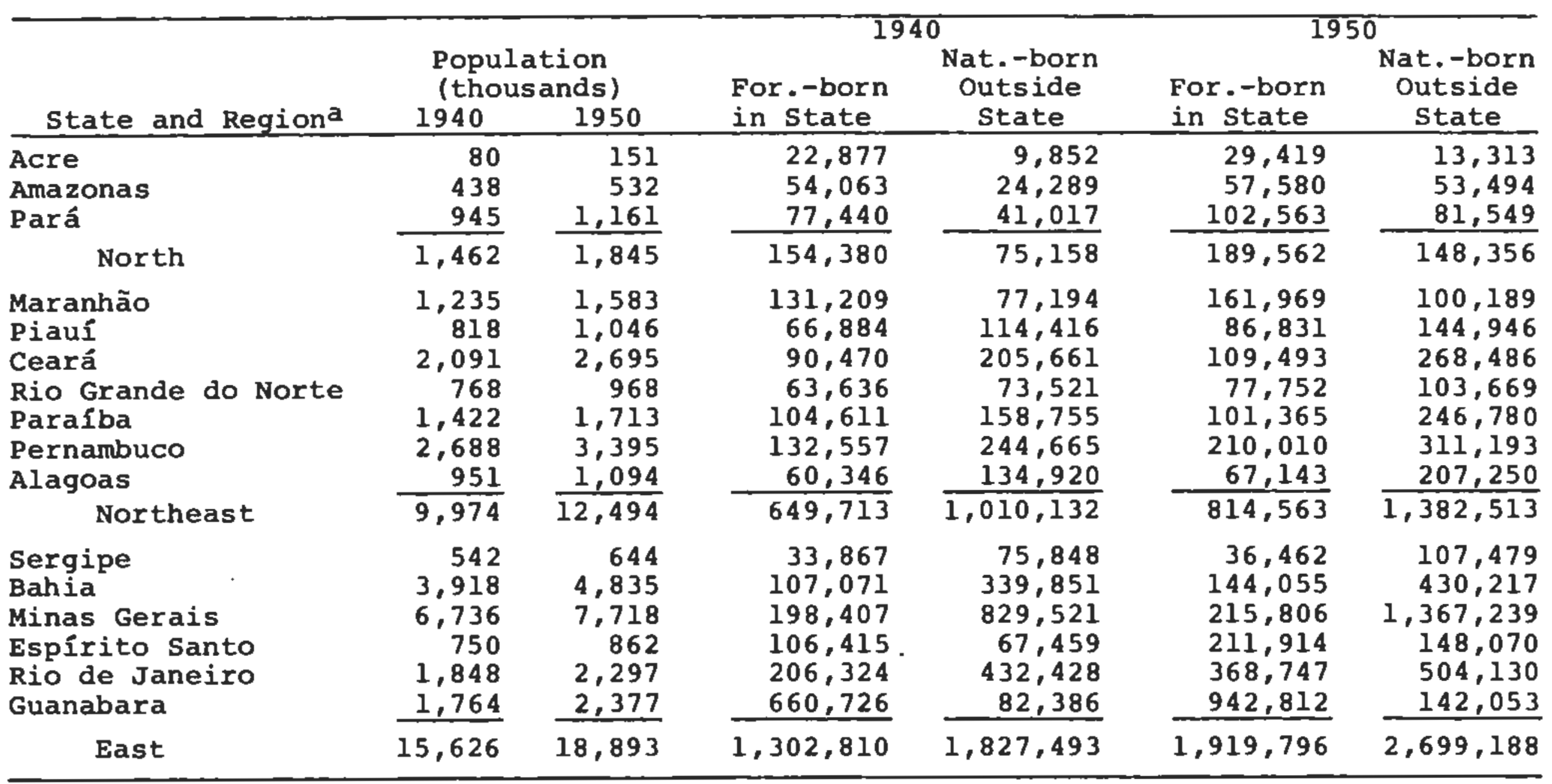




\begin{tabular}{|c|c|c|c|c|c|c|}
\hline \multirow[b]{3}{*}{ state and Regiona } & & & \multicolumn{2}{|c|}{1940} & \multicolumn{2}{|c|}{1950} \\
\hline & \multirow{2}{*}{\multicolumn{2}{|c|}{$\begin{array}{c}\text { Population } \\
\text { (thousands) } \\
1940 \quad 1950\end{array}$}} & & \multirow{2}{*}{$\begin{array}{c}\text { Nat. -born } \\
\text { Outside } \\
\text { State }\end{array}$} & & \multirow{2}{*}{$\begin{array}{c}\text { Nat. - born } \\
\text { Outside } \\
\text { State }\end{array}$} \\
\hline & & & $\begin{array}{l}\text { For.-born } \\
\text { in State }\end{array}$ & & $\begin{array}{l}\text { For.-born } \\
\text { in state }\end{array}$ & \\
\hline $\begin{array}{l}\text { São Paulo } \\
\text { Paraná } \\
\text { Santa Catarina } \\
\text { Rio Grande do Sul }\end{array}$ & $\begin{array}{l}7,180 \\
1,236 \\
1,178 \\
3,321 \\
\end{array}$ & $\begin{array}{l}9,134 \\
2,115 \\
1,560 \\
4,165 \\
\end{array}$ & $\begin{array}{r}749,539 \\
216,245 \\
108,519 \\
42,366 \\
\end{array}$ & $\begin{array}{r}231,330 \\
62,658 \\
61,451 \\
131,132 \\
\end{array}$ & $\begin{array}{r}1,080,428 \\
663,783 \\
152,926 \\
46,828 \\
\end{array}$ & $\begin{array}{r}507,248 \\
71,310 \\
118,748 \\
205,576 \\
\end{array}$ \\
\hline South & 12,916 & 16,975 & $1,116,669$ & 486,571 & $1,943,965$ & 902,882 \\
\hline $\begin{array}{l}\text { Goiás } \\
\text { Mato Grosso }\end{array}$ & $\begin{array}{r}826 \\
432 \\
\end{array}$ & $\begin{array}{r}1.215 \\
\quad 522 \\
\end{array}$ & $\begin{array}{r}155,732 \\
71,332 \\
\end{array}$ & $\begin{array}{l}36,014 \\
16,192 \\
\end{array}$ & $\begin{array}{l}282,450 \\
107,768 \\
\end{array}$ & $\begin{array}{l}36,333 \\
37,263 \\
\end{array}$ \\
\hline Central West & 1,259 & 1,737 & 227,064 & 52,206 & 390,218 & 73,596 \\
\hline Total & 41,236 & 51,944 & $3,450,636$ & $3,451,510$ & $5,258,104$ & $5,206,535$ \\
\hline
\end{tabular}

aEstimates for 1950 are based on 1940 political divisions.

Source: Population data, Atualidade Estatística do Brasil 1968 (Rio de Janeiro: IBGE, 1968); migration data computed from Censo Demográfico do Brasil 1940 and 1950 , Resultados Preliminários 1960 (Rio de Janeiro: IBGE, Serviço Nacional de Recenseamento), table 52 (1940) and table 43 (1950). 
whether it nas been a net loser. If the difference is positive, the state has gained from the migratory process. If the difference is negative, the state has lost. Notice that in a sense the concept provides a cross-sectional snapshot at a point in time of the result of past migrations by those living at the time. Data using this concept are presented in columns 1 and 2 of Table 17 .

The second concept is based on the first, and provides a crude estimate of the net population flows. By differencing the above concept, i.e., by subtracting the estimate for 1940 from that of 1950, an estimate can be obtained of the change in the "balance" between foreign-born living in the state and native-born living outside of the state. In a sense it is a crude estimate of the population changes during the decade as a result of inter-state migration. 5 It is crude because it ignores the effects of birth rates and death rates, for which precise data are not available. This estimate is presented in column 5 of Table 17.

The two concepts are useful when combined, since they can indicate significant turning points in the migratory process, even though data are available only for the one decennium. Amazonas is a case in point. The values in both column 1 and column 2 of Table 17 are positive, indicating that in each census year there were more foreign-born living in the state than native-born living outside the state. Taken individually, either one of these suggests that Amazonas has been a net recipient of inter-state migrants.

However, a comparison of 1950 with 1940 indicates that the excess of foreign-born living in the state over native-born living outside the state was less in the latter year. This suggests that during the decennium the state actually lost population due to the migration process (assuming that death rates do not affect migrants differently from the native population in the state). Further, the data suggests that what occurred during the 1940's was different from what had taken place previously. More specifically, the excess of 29,774 of foreignborn living in the state over native-born living outside the state suggests that, considered from the vantage point of 1940 , the effects of all previous 
migratory processes on the existing stock of population was such that in-migration had been greater than out-migration. However, during the 1940's the reverse was true. Out-migration was greater than in-migration. Hence, it is possible to discern a reversal of the migratory flow, although it is not known just when this reversal took place. (It could have taken place either prior to or after 1940.) Any change of sign among columns 1,2 , and 5 as one reads across a row will indicate such a reversal of the migratory flow.

Examination of columns 1 and 2 in Table 17, which provide two "snapshots" of the results of past migratory processes, indicates that there has been a Northeast-to-South-and-Central West migratory process. All of the states in the Northeast, with the exception of Maranhão, have more native-born living outside the state than foreign-born living in the state. In the South and Central West, all of the states, with the exception of Rio Grande do Sul, have more foreign-born in the state than native-born living outside the state.

The East is a transitional region. However, Sergipe, Bahia, and Minas Gerais, all of which border on the Northeast, have more out-migrants than inmigrants. Espírito Santo and Guanabara (the city of Rio de Janeiro), both of which are to the south, have more in-migrants. The state of Rio de Janeiro is an exception.

In both censuses the North has an excess of inmigrants over out-migrants.

The data in column 5 of Table 17 indicate a similar picture, although there are some important differences. In the North, the data suggest that both Amazonas and Para lost population through migration during this decade, with the result that in total the entire region lost. In the Northeast, Maranhão continued to gain population from migration, but the state of Pernambuco also gained. This is probably a result of migration to the capital city of Recife.

In the East, the state of Rio de Janeiro gained population from migration, as did the two other 
TABLE 17

Population Changes Through Migration, 1940, 1950, 1940-1950

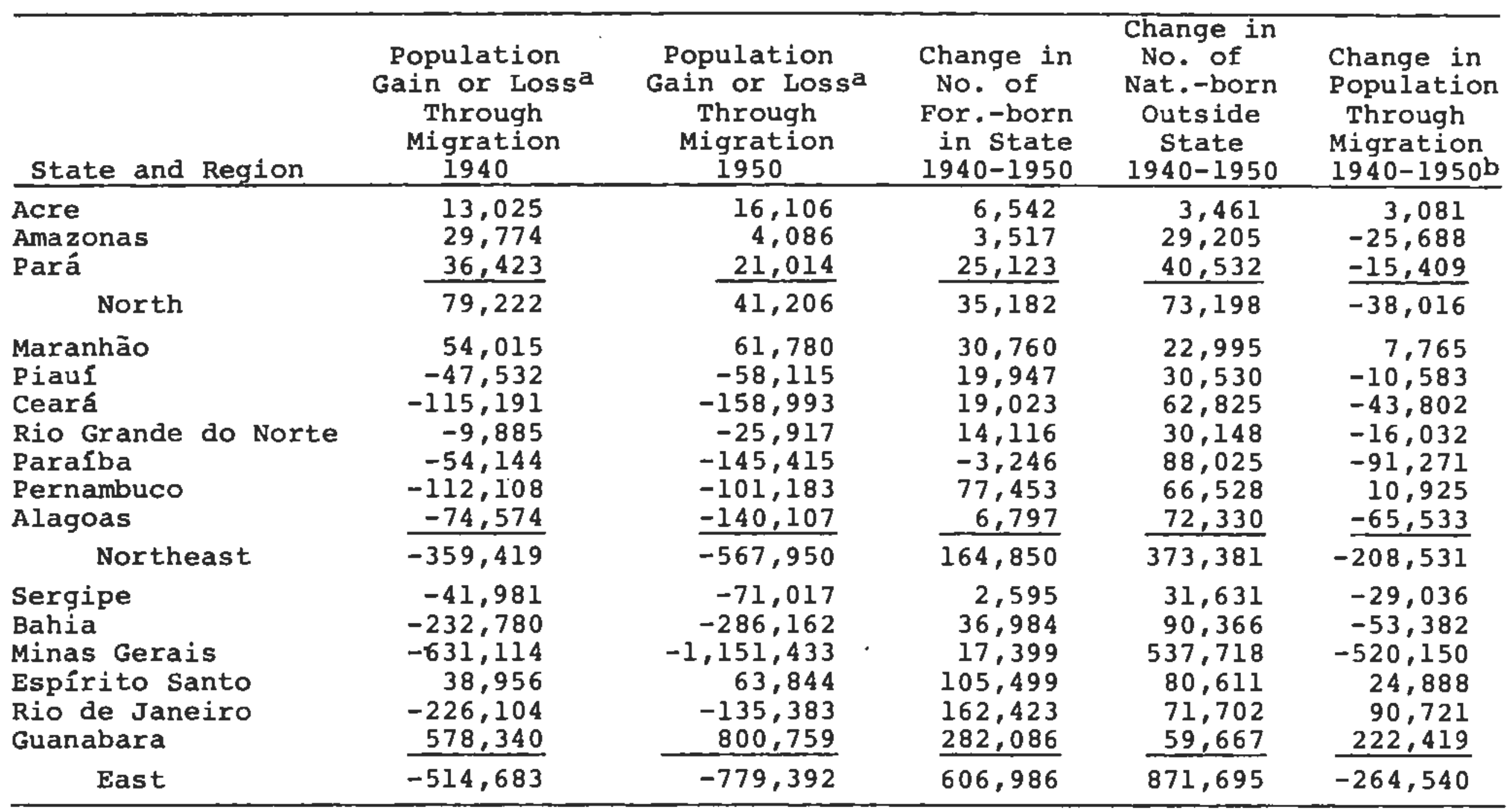




\begin{tabular}{|c|c|c|c|c|c|}
\hline State and Region & $\begin{array}{c}\text { Population } \\
\text { Gain or Loss } \\
\text { Through } \\
\text { Migration } \\
\text { l } 940\end{array}$ & $\begin{array}{c}\text { Population } \\
\text { Gain or Lossa } \\
\text { Through } \\
\text { Migration } \\
\text { l950 }\end{array}$ & $\begin{array}{l}\text { Change in } \\
\text { No. of } \\
\text { For.-born } \\
\text { in state } \\
1940-1950\end{array}$ & $\begin{array}{l}\text { Change in } \\
\text { No. of } \\
\text { Nat.-born } \\
\text { Outside } \\
\text { State } \\
\text { 1940-1950 }\end{array}$ & $\begin{array}{l}\text { Change in } \\
\text { Population } \\
\text { Through } \\
\text { Migration } \\
1940-1950^{b}\end{array}$ \\
\hline $\begin{array}{l}\text { São Paulo } \\
\text { Paraná } \\
\text { Santa Catarina } \\
\text { Rio Grande do sul }\end{array}$ & $\begin{array}{r}518,209 \\
153,587 \\
47,068 \\
-88,766 \\
\end{array}$ & $\begin{array}{r}573,180 \\
592,473 \\
34,178 \\
-158,748 \\
\end{array}$ & $\begin{array}{r}330,889 \\
447,538 \\
44,407 \\
4,462 \\
\end{array}$ & $\begin{array}{r}275,918 \\
8,652 \\
57,297 \\
74,444 \\
\end{array}$ & $\begin{array}{r}54,971 \\
438,796 \\
-12,800 \\
-69,982 \\
\end{array}$ \\
\hline South & 630,098 & $1,041,083$ & 827,296 & 416,311 & 410,985 \\
\hline $\begin{array}{l}\text { Goiás } \\
\text { Mato Grosso }\end{array}$ & $\begin{array}{r}119,718 \\
55,140 \\
\end{array}$ & $\begin{array}{r}246,117 \\
70,505 \\
\end{array}$ & $\begin{array}{r}126,718 \\
36,436 \\
\end{array}$ & $\begin{array}{r}319 \\
21,071 \\
\end{array}$ & $\begin{array}{r}126,399 \\
15,365 \\
\end{array}$ \\
\hline Central West & 174,858 & 316,622 & 163,154 & 21,390 & 141,764 \\
\hline
\end{tabular}

$a_{A}$ gain or loss is computed as the difference between the number of native-born in other states and the number of foreign-state natives now resident in the state in question.

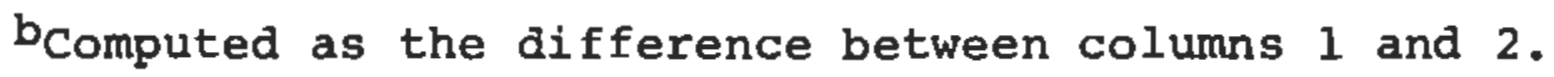

Source: Computed from Table 16 . 
southern states of the region, while the three northern states lost. However, the loss in Minas Gerais was so great that, on balance, the region lost. It is interesting to note that the migration from the East was considerably greater than from the Northeast, even though the migration from the semi-arid Northeast is given almost all the publicity. This is, in part, a definitional problem, since sergipe and parts of Bahia are usually included in the "drought polygon" of the Northeast. However, the fact remains that the heaviest population loss from a single state occurred in Minas Gerais, one of Brazil's traditional farming areas. The loss equaled almost $1.2 \mathrm{million}$ people, roughly 15 percent of the state's population in 1950.

In the south, santa Catarina became a net population exporter, together with Rio Grande do sul, but in this case the effect of são Paulo as a population recipient is so large that, on balance, the region is a population gainer. Both of the states in the Central West gained population from migration.

It is interesting to observe that the net population shifts during the decade, measured in this way, are over 500,000 people. However, this seriously underestimates the true migratory flows among states because it completely ignores mortality and back-andforth flows. It also understates total migration, since it ignores the very substantial within-state migration that is also taking place. The data are useful only as an indication of the direction of the flows and as a crude estimate of the magnitudes.

Data are provided in Table 18 which give some notion of the relative magnitude of the shifts. Column 1 expresses column 2 of Table 17 as a percentage of the total population in the state in 1950. Column 2 does the same thing for column 5 of Table 17. Column 2 is perhaps the more interesting, since it expresses the estimate of net population flows as a percentage of the underlying population base at the end of the migratory process. Most notable is the relatively large percentage shift out of Amazonas in the North, Paraíba and Alagoas in the Northeast, and Minas Gerais in the East; and the relatively large inward shifts into Guanabara (Rio de Janeiro, Paraná and Goiás.

Regrettably, the unavailability of the final data from the 1960 census precludes a continuation of this analysis into the decade of the $1950^{\prime} \mathrm{s}$. However, it appears that basically the same migratory patterns were being followed, with perhaps a substantially 
Relative Magnitude of Population Shifts, 1950 and 1940-1950

\begin{tabular}{|c|c|c|}
\hline & $\begin{array}{l}\text { Pop. Change } \\
\text { from Migration } \\
\text { as Percent of } \\
1950 \text { Pop.a }\end{array}$ & $\begin{array}{l}\text { Pop. Change } \\
\text { from Migration } \\
\text { as Percent of } \\
1950 \text { Pop. b }\end{array}$ \\
\hline $\begin{array}{l}\text { Acre } \\
\text { Amazonas } \\
\text { Pará } \\
\quad \text { North }\end{array}$ & $\begin{array}{r}+14.0 \\
+0.8 \\
+1.8\end{array}$ & $\begin{array}{l}+2.7 \\
-4.9 \\
-1.3\end{array}$ \\
\hline $\begin{array}{l}\text { Maranhão } \\
\text { Piauf } \\
\text { Ceara } \\
\text { Rio Grande do Norte } \\
\text { Paraiba } \\
\text { Pernambuco } \\
\text { Alagoas } \\
\quad \text { Northeast }\end{array}$ & $\begin{array}{l}+3.9 \\
-5.5 \\
-5.9 \\
-2.5 \\
-8.4 \\
-2.9 \\
-12.8\end{array}$ & $\begin{array}{l}+0.4 \\
-1.0 \\
-1.6 \\
-1.6 \\
-5.3 \\
+0.3 \\
-5.9\end{array}$ \\
\hline $\begin{array}{l}\text { Sergipe } \\
\text { Bahia } \\
\text { Minas Gerais } \\
\text { Espirito Santo } \\
\text { Rio de Janeiro } \\
\text { Guanabara } \\
\quad \text { East }\end{array}$ & $\begin{array}{r}-11.0 \\
-5.9 \\
-14.9 \\
+7.4 \\
-5.9 \\
+33.7\end{array}$ & $\begin{array}{l}-4.6 \\
-1.1 \\
-6.8 \\
+2.9 \\
+4.9 \\
+9.3\end{array}$ \\
\hline $\begin{array}{l}\text { São Paulo } \\
\text { Paraná } \\
\text { Santa Catarina. } \\
\text { Rio Grande do Sul } \\
\quad \text { South }\end{array}$ & $\begin{array}{r}+6.2 \\
+28.0 \\
+2.2 \\
-3.8\end{array}$ & $\begin{array}{r}+0.6 \\
+20.7 \\
-0.8 \\
-1.6\end{array}$ \\
\hline $\begin{array}{l}\text { Goiás } \\
\text { Mato Grosso } \\
\text { Central West }\end{array}$ & $\begin{array}{l}+20.3 \\
+13.5\end{array}$ & $\begin{array}{r}+10.4 \\
+2.9\end{array}$ \\
\hline
\end{tabular}

${ }^{a}$ Column 2, Table 17 , as a percentage of the 1950 population.

${ }^{b}$ Column 5, Table 17 , as a percentage of the 1950 population.

17.

Source: Computed from data in Tables 16 and 
larger rate of migration. For example, in 1940 rough ly 3.4 million Brazilians, or 8.5 percent of the tota population, were living outside their state of birth. By 1950 this had increased to 5.2 million, or 10.3 percent of the total; and by 1960 it was 12.5 million or 18.2 percent of the total.

The continuation of the regional shift can be seen from the following estimates of the population growth rates for the decade of the $1950^{\prime} \mathrm{s}$ by region. 6

\begin{tabular}{ll} 
North & 3.44 \\
Northeast & 2.20 \\
Southeast & 3.18 \\
South & 4.17 \\
Central West & 5.55 \\
\hline & \\
\hline & 3.01
\end{tabular}

Although the definition of a region is somewhat different from that used above, 7 these data suggest that the South and Central West continued to gain relative to the rest of the country, and largely at the expense of the Northeast. The data also suggest that there may have been a net flow into the North during this decade.

This migratory process has probably been further facilitated in the 1960 's by improvements in the North-South highway system. The Rio-Bahia highway, opened in 1964 , provides a paved highway. from the Northeast to the South. The Belo HorizonteBrasilia and the Brasilia-Belem highways provide a means of entering the interior of the Central West. And work on the Belem-Fortaleza-Recife system should facilitate movement from the Northeast into the North.

The Rural-Urban Flow

It is of interest to know what part of this migration represents a rural-urban flow. Once again no precise estimate is available, and the estimates have to be made in implicit ways.

Despite the fact that urbanization is taking place at a rapid rate in Brazil, a sizable portion of the population shifts discussed above are a result of migration from one rural area to another. For example, population additions through migrations 
to the states of Maranhão, Paraná, Mata Grosso, and Goias are principally a rural-to-rural phenomenon, since the recipient areas are principally agricultural. Even in Säo Paulo, the most highly industrialized state in Brazil, 75.2 percent $(386,000$ people between 1940 and 1950) of the migrants from Minas Gerais were found living in rural areas.

Summary data on the population by rural and urban sectors are presented in Table 19. The very rapid urbanization which has taken place since 1940 can be clearly seen. Rural population as a percent of total population fell from 69 percent to 64 percent from 1940 to 1950 , and from 64 percent to 54 percent from 1950 to 1960. It is estimated that in 1965 the urban population was larger than the rural population for the first time.

Between 1940 and 1950 the rural population grew at a net rate of 1.6 percent a year, while the urban grew at a rate of 3.9 percent. The average growth rate of the total population for this period was 2.3 percent. Between 1950 and 1960, the rural population grew at a slightly lower rate of 1.3 percent, urban population grew at a much greater rate of 5.6 percent, and the average rate of growth for the total population increased to 3.0 percent. Clearly, the rural-to-urban migration rate increased between the two decennia at the same time that the rate of increase of the total population increased.

Estimates of the magnitude of the migration can be made by assuming that the rural and urban populations had the same natural rates of increase ${ }^{8}$ and, on this basis, estimating what the population in the two sectors would have been in the absence of migration. A comparison of these estimates with the actual populations indicates the magnitude of the migration.

Given the underlying assumption, it appears that approximately 2.5 million people moved from rural to urban areas between 1940 and 1950. This was equal to slightly over 6 percent of the rural population in 1940. Between 1950 and 1960 there were almost 7 million rural-urban migrants, which was equal to almost 20 percent of the rural population in 1950. Thus, both absolute numbers and the rate of migration almost tripled between the two decennia. It is interesting to note that despite this relatively large rate of migration, the rural population continued to grow at a fairly rapid rate. 


\section{TABLE 19}

Quantity and Rate of Population Growth by Area of Residence, $1940,1950,1960$

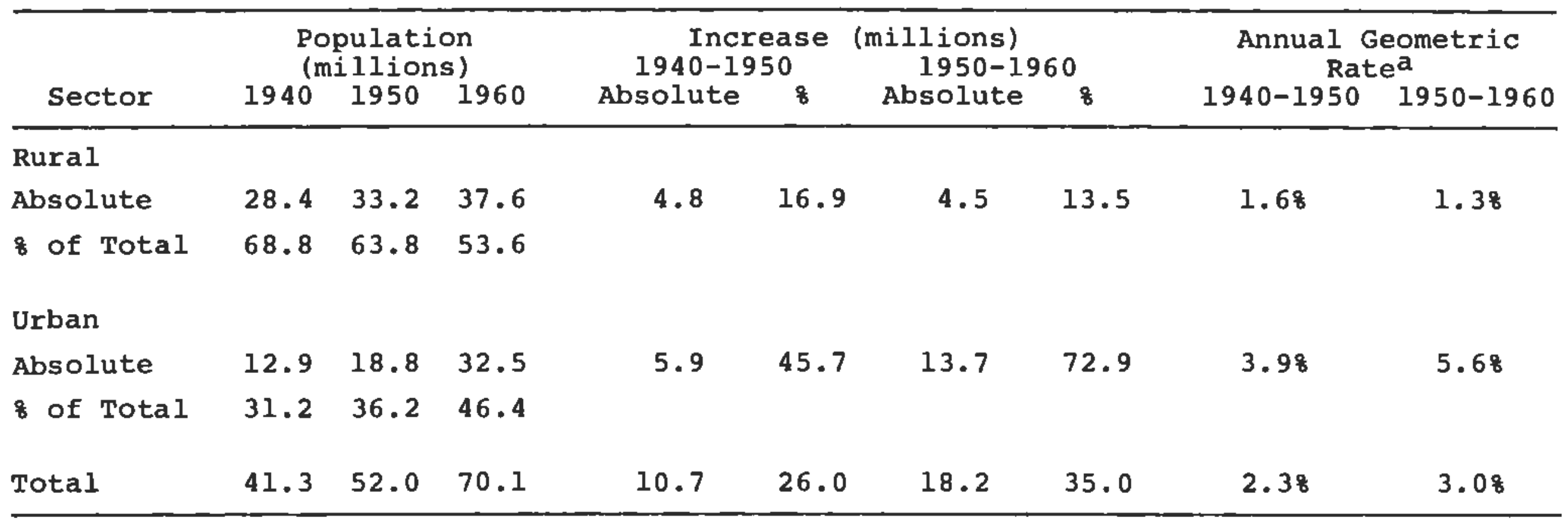

acalculated from population $1960=$ population $1950(1+\alpha)^{n}$ Where $\alpha=$ annual geometric growth rate and $\mathrm{n}=10$

Source: Censo Demográfico do Brasil, 1940 and 1950, Resultados Preliminários 1960 (Rio de Janeiro: IBGE, Serviço Nacional de Recenseamento). 
TABLE 20

Estimated Rural-Urban Migration, 1940-1950 and 1950-1960 (millions)

\begin{tabular}{|c|c|c|c|c|c|c|c|c|}
\hline & 1940 & 1950 est.a & $\begin{array}{c}1950 \\
\text { Actual }\end{array}$ & $\begin{array}{c}1940-1950 \\
\text { Est. } \\
\text { Migration }\end{array}$ & 1950 & 1960 est.b & $\begin{array}{c}1960 \\
\text { Actual }\end{array}$ & $\begin{array}{c}1950-1960 \\
\text { Est. } \\
\text { Migration }\end{array}$ \\
\hline Urban & 12.9 & 16.3 & 18.8 & +2.5 & 18.8 & 25.5 & 32.5 & +7.0 \\
\hline Rural & 28.4 & 35.7 & 33.2 & -2.5 & 33.2 & 44.6 & 37.6 & -7.0 \\
\hline Total & $41 \cdot 3$ & 52.0 & 52.0 & & 52.0 & 70.1 & 70.1 & \\
\hline
\end{tabular}

aThe basic assumption is that population grew in rural and urban areas at the same rate, equal to the country average of 2.38 for 1940-1950. The basic formula is that 1950 rural (urban) population $=1940$ rural (urban) population $(1+\alpha) N$, where $\alpha=2.38$ and $\mathbf{N}=10$.

$b_{T h e}$ national rate of growth for 1950-1960 was 3\%. The same formula was used to generate 1950-1960 estimates. 
The analysis of the labor market ${ }^{9}$ is based on aggregate employment data by sector, and on wage rates and income per employed worker by sector. The analysis is based on the 1940-1960 period since more recent data are not available.

\section{Inter-Sectoral Changes In Employment}

The structure of employment in Brazil has been undergoing substantial changes in the postwar period. Not all of these changes are in the direction one might expect in a country undergoing rapid industrialization.

Brazilian labor force data are based on a concept of "potential labor force," which includes the population 10 years of age and over.10 The population in this age group is classified as employed (by sector of employment) or inactive. The "inactive" category is a catch-all for all those not directly employed in remunerative activities, and includes those in unpaid domestic activities, pensioners, retired persons, students, and so forth.

The population over 10 years of age increased by 19.7 milition in the interval from 1940 to 1960 , and it is estimated that the rural sector contributed approximately 70 percent of this increase. A major portion of this increase has been transferred out of agriculture (at least out of active employment), and the data in Table 21 suggest that it is, at least in the latter decade, being absorbed in large part by the service sector or the "inactive" category. In terms of the annual rate of growth, the number of people in agriculture increased between 1940 and 1960 at a rate of approximately 1 percent a year. Industrial employment grew at a much higher rate over the entire period, as did employment in the service sector.

The difference in growth rates between the two decennia is of major interest. Employment in agriculture increased between 1950 and 1960 at more than three times the rate it had increased between 1940 and 1950. The rate of employment increase in industry was substantially less between 1950 and 1960 
TABLE 21

People Economically Active by Sector, Age 10 and Over, 1940, 1950, 1960

\begin{tabular}{|c|c|c|c|c|c|c|c|}
\hline \multirow[b]{2}{*}{ Sector $\mathbf{a}^{\mathrm{a}}$} & 1940 & 1950 & $1960^{b}$ & \multicolumn{2}{|c|}{ Change } & \multicolumn{2}{|c|}{ \& Change } \\
\hline & \multicolumn{2}{|c|}{ Millions } & & $1940-1950$ & Annual & $1950-1960$ & Annual \\
\hline Agriculture & 9.7 & 10.2 & 12.1 & 5.6 & .6 & 18.3 & 1.7 \\
\hline Industry & 1.6 & 2.4 & 3.1 & 56.1 & 4.6 & 28.9 & 2.3 \\
\hline $\begin{array}{l}\text { Service } \\
\quad \text { Commerce } \\
\text { Transportation, }\end{array}$ & $\begin{array}{r}3.5 \\
.7\end{array}$ & $\begin{array}{l}4.4 \\
1.0\end{array}$ & $\begin{array}{l}7.4 \\
1.5\end{array}$ & $\begin{array}{l}26.8 \\
27.9\end{array}$ & $\begin{array}{l}2.4 \\
2.5\end{array}$ & $\begin{array}{l}66.5 \\
58.6\end{array}$ & $\begin{array}{l}5.2 \\
4.5\end{array}$ \\
\hline $\begin{array}{l}\text { Communication } \\
\text { Government, } c\end{array}$ & .5 & .7 & 1.1 & 45.5 & 3.9 & 56.3 & 4.6 \\
\hline Personal Services & 2.3 & 2.8 & 4.8 & 22.6 & 2.1 & 71.8 & 5.5 \\
\hline Total Active & 14.8 & 17.1 & 22.7 & 16.0 & 1.5 & 32.3 & 2.8 \\
\hline Inactive & 14.3 & 19.4 & 26.1 & 36.1 & 3.1 & 34.4 & 3.0 \\
\hline Total Age 10 and Over & 29.0 & 36.6 & 48.8 & 25.9 & 2.1 & 33.4 & 2.9 \\
\hline
\end{tabular}

asectors are defined according to the national accounts criterion.

bThe data for 1960 are preliminary and are not presented on as detailed a base as those for 1940 and 1950. In adjusting the census data so that the sectors are the same as the national accounts criterion, some estimates had to be made. These were made by assuming that the 1950 classes of employment proportions are the same'in 1960.

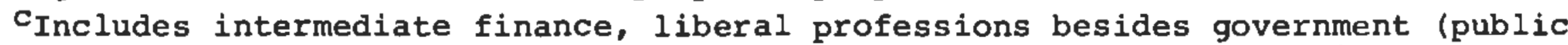
safefy, military, schools, and hospitals), and private schools and hospitals.

Source: Censo Demográfico do Brasil 1940 and 1950, Resultados Preliminarios 1960 (Rio de Jañeiro: IBGE, Servíço Nacional de Recenseamento). 
TABLE 22

Employment in Major Sectors as Percent of Total Employed Labor Force, 1940, 1950, 1960

\begin{tabular}{lccc}
\hline \multicolumn{1}{c}{ Sector } & 1940 & 1950 & 1960 \\
\hline Agriculture & 65.7 & 59.8 & 53.5 \\
Industry & 10.6 & 14.2 & 13.9 \\
Service & 23.7 & 25.9 & 32.6 \\
$\quad$ Commerce & 5.1 & 5.6 & 6.7 \\
$\begin{array}{l}\text { Pransportation, } \\
\quad \text { Communication }\end{array}$ & 3.2 & 4.0 & 4.8 \\
$\begin{array}{l}\text { Government, } \\
\text { Personal Services }\end{array}$ & 15.4 & 16.3 & 21.1 \\
\hline
\end{tabular}

asectors conform to the national income account sectors and are slightly different from the demographic census sectors.

Source: Calculated from data in Table 21 . 
than it had been between 1940 and 1950 , with the result that as a fraction of the employed labor force, it actually declined between 1950 and 1960. (See Table 22.) The rate of employment increase in the service sector was twice as great between 1950 and 1960 as it was between 1940 and 1950 . The "inactive" category increased during the 1950-1960 decade at about the rate of increase of the population over age 10, although it had increased somewhat faster in the previous decade.

Thus, we see a major shift in the labor market between the two. decades--a shift which has very important implications. In the 1940's employment in the service sector was increasing at about the same rate as the rate of population increase, while the industrial sector was absorbing labor at a much Easter rate, and apparently absorbing the migrants from the rural areas into this much more productive sector. The "inactive" category was increasing at a faster rate than the rate of population increase, but this was probably due to the better schooling opportunities in urban areas and the decline in employment opportunities for the young.

In the 1950's the industrial sector did not absorb labor even at the same rate that the employed labor force was growing, with the result that employment was forced to grow more rapidly in the lower-productivity agricultural and service sectors. This was the case despite the fact that the decade of the 1950 's was a period of very rapid industrial growth in which the economy was "tight" throughout the period. This is clearly a very important structural problem. It contrasts in an interesting way with the U.S. postwar experience, where labor was dammed up in the agricultural sector because of high unemployment rates associated with inadequate aggregate demand. In Brazil the labor is being dammed up in agriculture, or channeled into the low-productivity service sector, because of a lack of employment opportunities in the industrial sector that arises from structural difficulties. The industrial sector did expand rapidly, and lack of aggregate demand was not the problem. The output expansion just did not create many additional jobs.

Insights into the magnitude of the problem can be seen by making a more detailed analysis. Between 1950 and 1960 the increase in total population was 
18.2 million. In 1960,67 percent, or 12.2 million, were over 10 years of age and therefore in the potential labor force. We have estimated net migration from the rural areas to be 7 million for the decade 1950-1960. In the same period urban population increased by 13.7 million, indicating that the increase in urban population without the migrants was 6.7 million people. If we assume that the age structure for the rural and urban sectors was identical (not necessarily valid, but used for lack of a better alternative), then 67 percent of these, or 4.5 million, were in the potential labor force. At the same time, rural population increased by $4.5 \mathrm{million}$ people after migration in the 1950-1960 decade. Without migration, it would have increased 11.5 million. Assuming the same participation rate, without migration there would have been 7.7 million in the rural potential labor force.

After migration the rural areas had 3 million potential workers left, and the urban areas had 9.2 million. Rural employment increased by 1.9 million during 1950-1960, leaving 1.1 million in rural areas who became inactive. Of the $9.2 \mathrm{million}$ urban potential workers, only 3.7 million were employed in 1960, with industry taking only .7 million and services 3.0 million. The balance $(5.5$ million) joined the ranks of the "inactive" category in urban areas.

From this it should be clear that the stability of the petcent inactive between 1950 and 1960 is not a cause for complacency. There appear to be very important sectoral imbalances in this component, even though the analysis is at best crude. Of the increase of 3.0 million members in the rural potential labor force, some 60 percent were employed in agriculture. of the increase of 9.2 million in the urban potential labor force, only 40 percent were employed.

It is clear that important structural differences exist among the sectors. Educational opportunities are much greater in urban areas, and in fact many migrants go to urban areas in order to obtain schooling. Labor laws are such that child labor is much more common in rural areas than in urban areas. And the labor force participation rates of women are probably lower in the urban sector than in the rural sector. It is doubtful, however, whether these differences can explain the entire discrepancy. It therefore appears that in addition to the sectoral 
imbalance in employment among the primary, secondary, and tertiary sectors, about which more will be said later, there is also a problem of the portion of the labor force that is employable in urban areas.

\section{Income and Productivity Differentials}

Despite the rather high rates of mobility shown above, and the rather large migratory flows, sizable differences in per capita incomes and labor productivities exist in Brazil. Differentials exist both on a geographic basis and among economic sectors.

One of the easiest ways to show these differentials in summary form is with wage data. Table 23 presents average wages for non-skilled labor working in the rural areas of selected states in Brazil. A comparison is provided between agricultural wages and non-agricultural wages. In the latter case, wages for non-skilled labor were selected because they would appear to be the most immediate employment opportunity for the agricultural labor force. For the most part, non-agricultural employment in rural areas tends to be in the textile and food preparation industries.

The data document the rather large geographic differentials which exist in both agricultural and non-agricultural employment, as well as the rather large differential between agricultural and nonagricultural wages within the same state. Wage rates within the agricultural sector tend to have a northsouth pattern that is very similar to the east-west pattern in agricultural wages in the united states. The average wages are lowest in Ceark and increase gradually as one moves south, with the highest rate occurring in Rio Grande do sul--the southernmost state in the country.

The variations in wages in non-agricultural rural employment are much greater than those in agriculture. In addition, they do not have the same systematic north-south pattern. The lowest wages are in Goids, a state in the central interior, with Mato Grosso and ceard following closely. The highest money wages in non-agricultural rural employment are paid in são Raulo, and these are substantially above those in any other state. 
Net Internal Income per Capita, Rural and Urban, 1947-1965 (1953 prices)

\begin{tabular}{|c|c|c|c|c|}
\hline \multirow[b]{2}{*}{ Year } & \multirow{2}{*}{$\begin{array}{l}\text { Primary } \\
\text { Per Capita } \\
\text { Income }\end{array}$} & \multirow{2}{*}{$\begin{array}{l}\text { ector } \\
\text { Percent } \\
\text { Change }\end{array}$} & \multicolumn{2}{|c|}{$\begin{array}{c}\text { Secondary, Tertiary } \\
\text { Sectors }\end{array}$} \\
\hline & & & $\begin{array}{l}\text { Per Capita } \\
\text { Income }\end{array}$ & $\begin{array}{l}\text { Percent } \\
\text { Change }\end{array}$ \\
\hline & $(\mathrm{NCr} \$)$ & & $(\mathrm{NCr} \$)$ & \\
\hline 1947 & 2.64 & --- & 10.53 & --- \\
\hline 1948 & 2.79 & 5.4 & 11.18 & 6.1 \\
\hline 1949 & 2.87 & 2.8 & 11.44 & 2.4 \\
\hline 1950 & 2.87 & .1 & 11.80 & 3.1 \\
\hline 1951 & 2.85 & -.7 & 11.74 & -.5 \\
\hline 1952 & 3.06 & 7.5 & 11.45 & $-2 \cdot 5$ \\
\hline 1953 & 3.03 & $-1 \cdot 0$ & 11.23 & -1.9 \\
\hline 1954 & 3.23 & 6.6 & 11.42 & 1.7 \\
\hline 1955 & 3.44 & 6.2 & 11.46 & .4 \\
\hline 1956 & 3.31 & -3.5 & 11.28 & -1.6 \\
\hline 1957 & 3.58 & 7.9 & 11.40 & 1.0 \\
\hline 1958 & 3.60 & .8 & 11.80 & 3.5 \\
\hline 1959 & 3.75 & 4.0 & 12.34 & 4.6 \\
\hline 1960 & 3.89 & 3.7 & 12.64 & 2.4 \\
\hline 1961 & 4.11 & 5.8 & $\mathbf{a}$ & --- \\
\hline 1962 & 4.27 & 3.9 & 12.74 & --- \\
\hline 1963 & 4.25 & -.5 & 12.48 & -2.1 \\
\hline 1964 & 4.24 & -.2 & 12.63 & 1.2 \\
\hline 1965 & 4.75 & 12.1 & 12.11 & -4.2 \\
\hline
\end{tabular}

anot available.

Source: Based upon real income per sector, as calculated in Table 26, and estimates of the rural and urban population. 
The analysis must proceed on this basis for lack of a better alternative. It would appear that the resulting data do provide rough measures of the sectoral differences in per capita incomes and their relative movement over time.

One of the striking aspects of the table is the rather large differential between the farm and non-farm sectors. Although part of the differential can be explained by differences in the cost of living between the rural and urban sectors, it is not likely that all of it could be so explained. Even if there were a 100 percent difference in the cost of living, the difference in per capita incomes would still be substantial. of course, the motivation for the rather large rural-urban migration documented above is the existence of this large difference in per capita incomes.

It is interesting to note that, in a relative sense, per capita incomes in the farm sector have risen in relation to those in the non-farm sector in the postwar period. Two comparisons will be made. The first will compare the 1947-1949 period with the average of 1960 and $1962--t h e$ last years prior to the economic stagnation which set in in 1963. The second will compare the earlier period with the average of 1964 and 1965. 1964 was not a good agricultural year, but this is offset in part by 1965 , which was characterized not only by good weather conditions but also by economic measures which sought to transfer incomes from the non-farm to the farm sector. The common interpretation of the stagnation which began in 1963 was that it resulted from an exhaustion of import-substitution industrialization possibilities and from a failure of the internal market to "extend" because of rural poverty. This interpretation, plus bad weather in both 1963 and 1964, led to policy measures more favorable to agriculture. The agricultural prices were freed up at the same time that other supporting policies were implemented. The effect of these measures, plus the very good crop year of 1965, is shown in the relatively large rise in per capita incomes for the farm sector. The degree to which this was at the expense of the non-farm sector is indicated by the decline in per capita incomes for the latter sector. 
Per capita incomes in the farm sector increased NCr\$1.31 between 1947-1949 and the 1960-1962 period. Non-farm incomes increased NCr\$1.64 for the same period. Although in absolute terms the increase was larger in the non-farm sector, it is interesting to note that the relative increase for the farm sector was 47.4 percent, while that for the non-farm sector was only 14.8 percent.

If the 1964-1965 period is used as a base, the change is even more favorable to agriculture. Compared with the 1947-1949 base, per capita incomes in the farm sector increased NCr\$1.73, while those in the non-farm sector increased only NCr\$1.32. This is a 62.4 percent increase in per capita rural incomes, and only an 11.9 percent increase in nonfarm incomes.

These data suggest that the relatively large migratory flows in the postwar period did act to reduce the income differentials between the farm and non-farm sectors. The large differentials which remain between the two sectors, however, suggest that the migratory flows did not bring the labor market into equilibrium and that the migratory flow is likely to continue well into the future unless economic conditions should change substantially. (The limitations of the per capita income estimates should be remembered in assessing the income differentials.)

\section{Inter-sectoral Differences in Productivity}

Data on average labor productivity can provide further insights into the labor market and the extent to which it is handling its allocating function properly. In this section, we turn to an analysis of such data.

The two-sector models of economic development have basically divided the economy into an industrial sector and an agricultural sector. Early formulations of these models argued that an essential task of development was to transfer labor from the agricultural sector, where labor was assumed to have a zero marginal product, to the industrial sector, where it had a much higher marginal product. In this way total output would be increased. 
More recent formulations have abandoned the zero marginal product for the agricultural labor hypothesis, but they still argue that a major problem in the development process is to transfer labor from the low-productivity agricultural sector to the higher-productivity industrial sector. In either case a major policy prescription implied by the models is a strong industrialization policy which would provide expanding job opportunities in the more productive sectors.

In the context of a static model, and with certain restrictions, one would expect this transfer to continue until the marginal product of a unit of labor, properly defined, would be equal in the two sectors. In fact, this is the criterion usually used for evaluating the efficiency of the labor market.

When one is restricted to average productivities, however, there is less that one can say in a systematic way. There is a presumption, however, that average productivities would converge unless capital-labor substitution possibilities are limited. Suppose, for example, that capital-labor substitution possibilities were unlimited and that the initial differences in labor productivity among sectors were due to differences in relative capital endowments or capital intensities. If the differences in labor productivity were reflected in real wages, labor would have an incentive to move from the low-productivity sector to the high-productivity sector. Assuming that the capital stocks remained unchanged, the resulting change in proportions would change the capital (or labor) intensity of the respective sectors and the respective labor productivities would converge.

If this convergence does not take place, it must be for one or a combination of three reasons:

1. As the economy expands, economic incentives are such that investments are induced in the capitalintensive sector, even though this sector already has a relatively high capital intensity. This could happen, for example, if the government were stimulating the growth of the industrial sector and if capital-labor price ratios were different in the industrial sector. In essence, the capital stock outruns the flow of migrants. 


\section{TABLE 23}

Monthly Wages of Unskilled Rural Labor, Selected States, 1959

\begin{tabular}{lcc}
\hline & \multicolumn{2}{c}{$\begin{array}{c}\text { Type of } \\
\text { Agricultural } \\
\text { (NCr\$) } \\
\text { Non-agricultural }\end{array}$} \\
\hline Maranhão & 1.90 & 6.54 \\
Ceara & 1.61 & 2.92 \\
Pernambuco & 2.05 & 15.38 \\
Bahia & 2.06 & 7.83 \\
Minas Gerais & 2.30 & 24.19 \\
Rio de Janeiro & 2.85 & 19.40 \\
São Paulo & 3.65 & 67.82 \\
Parana & 3.68 & 18.14 \\
Santa Catarina & 3.63 & 17.70 \\
Rio Grande do Sul & 4.30 & 18.90 \\
Mato Grosso & 3.24 & 2.70 \\
Goiás & 3.30 & 2.13 \\
\hline
\end{tabular}

Source: Anuario Estatístico do Brasil 1963 (Rio de Janeiro: IB̈GE, 1964), PP. 83-93, $2 \overline{3}$. 
The extent to which these differences in money wages reflect real differences in wages for labor of the same quality is not known, nor are data available to make such estimates. However, the rather significant differences between agricultural and nonagricultural employment in the same state would not appear to be due to differences in the cost of living, since both are measured in rural areas.

In order to make a comprehensive analysis of the labor market, data on wage rates and labor income, plus estimates of the marginal productivity, would be necessary. Such data would indicate whether the rather large labor transfers of the past have been equilibrating and would suggest the magnitude of the labor transfer still necessary. Unfortunately, such data are not available on a scale sufficient to make a satisfactory analysis.11

Because of this, we turn to data on average per capita incomes and on average labor productivity for the analysis which is to follow. Although such data must be used with care, when combined with data on population shifts and employment they can provide insights into the labor market and how well it is functioning.

Sectoral Income Differentials

One interesting question has to do with what is happening to per capita incomes on a sectoral basis. Table. 24 provides such data for the postWorld War II period, with the primary sector compared with the secondary (industrial) and tertiary (service) sectors combined. In using the data as a comparison of farm and non-farm incomes, two limitations of the data must be kept in mind. First, net internal income from the primary sector includes more than agricultural income. However, agriculture makes up the major portion of this component, and trends are dominated by what happens in the agricultural sector. Second, income from the primary sector has been divided by rural population, while income from the secondary and tertiary sectors has been divided by the urban population. strictly speaking, neither of these population groups coincides exactly with the source of income attributed to them. 
2. Capital-labor substitution possibilities are limited in the expanding sector. For example, suppose the industrial sector is by definition capital-intensive and that opportunities for a less capital-intensive organization do not exist.

3. The rate of technical change in the expanding sector is more rapid than in the trailing sector. In this case labor productivity in the lead sector may outrun the trailing sector, even though migration is taking place at a rapid rate. The discrepancy rides on differences in the intangible capital in each sector, however, and not the tangible capital, although these may be correlated.

For now we leave these pọsible explanations aside and turn to the evidence on Brazil.

Data on internal income per economically active person (member of the labor force), by sector, is provided in Table 25. These data provide crude estimates of average labor productivity. The data should be compared with the data on employment. (See Table 21.)

A sharp contrast exists in the experience between the two decades considered in Table 25. In the 1940 's, labor productivity was increasing in all three sectors. Labor productivity increased less in the agricultural sector than in the other two sectors, despite the fact that the agricultural labor force was expanding only very slowly (i.e.., the out-migration was large). Productivity in the industrial and service sectors increased by approximately the same amount, and was approximately of the same order of magnitude.

In the 1950's, however, labor productivity in the industrial sector spurted well ahead of that in the other two sectors. Productivity in the agricultural sector increased, but only about a third as much as in the industrial sector. In the service sector, on the other hand, productivity actually declined over the period.

A more detailed look at the service sector indicates that productivity increased for two of its major components. For the third component, government and personal services, average productivity (or average income per person employed) declined substantially. 
TABLE 25

Real Internal Income per Economically Active Person, by Sector, 1940, 1950, 1960 (1953 Cr\$)

\begin{tabular}{|c|c|c|c|c|c|}
\hline Sector & 1940 & $\begin{array}{l}1950 \\
\text { (NCr\$) }\end{array}$ & 1960 & $\begin{array}{c}\text { Percent Change } \\
1940-1950\end{array}$ & $\begin{array}{c}\text { Percent Change } \\
1950-1960\end{array}$ \\
\hline Agriculture ${ }^{a}$ & 8.2 & 9.3 & 12.1 & 11.3 & 30.1 \\
\hline Industry $\mathbf{y}^{\mathrm{a}}$ & 21.8 & 29.7 & 55.1 & 36.5 & 85.5 \\
\hline Service & 24.8 & 33.1 & 32.3 & 33.5 & -2.4 \\
\hline Commerce & -- & 43.9 & 52.6 & -- & 19.8 \\
\hline $\begin{array}{c}\text { Transportation, } \\
\text { Communication }\end{array}$ & -- & 30.2 & 39.1 & -- & 29.5 \\
\hline $\begin{array}{l}\text { Government, } \\
\text { Pergonal Service }\end{array}$ & -- & 30.0 & 24.1 & -- & -20.0 \\
\hline Total & 13.6 & 18.4 & 24.6 & 36.3 & 33.7 \\
\hline
\end{tabular}

asince agricultural income includes that generated by forestry, while forestry employees are counted as part of industry, the income per occupied person is overestimated for agriculture and underestimated for industry.

Source: Synthesized from the sectoral income as reported in Table 2.6 and the number of people economically active by sector, Table 21 . 
Three aspects of this phenomenon are of note. First, as Table 21 indicates, government and personal services form by far the largest component of the tertiary sector. Second, by 1960 the average income per employed person was driven down until it was approximately twice as large as the income per employed person in agriculture. If the difference in cost of living between the rural and urban sectors should be farily large--say 100 percent--then average productivity in real terms between the two sectors might have been approximately equal in 1960. Third, the personal service and government sector is very heterogeneous. In the government sector it ranges from highly qualified technicians and professionals to the unskilled funcionarios. Personal services range from doctors, dentists, and lawyers to maids and other servants. Although data are not available to disaggregate this component further, it is most likely that income per member of the labor force has declined primarily on the low-skilled end of this spectrum.

A comparison of the data in Table 25 with those in Table 21 suggests that the shifts in average income per employed person during the 1950's can be explained in large part as a result of supply shifts in the labor force. Labor force growth was largest in the service sector; and within the service sector, it was largest in the government and personal services component. The labor force in the industrial sector grew at a lower rate than the growth of the total labor force, even though average income per employed person was much higher than in the other sectors by 1960. Income per employed person in agriculture grew as a result of the relative shift out of the rural migrants, but not nearly as much as in the industrial sector.

An overall evaluation of the performance of the labor market therefore leaves a rather mixed picture. In some respects it was equilibrating. Labor was leaving the low-productivity agricultural sector and going to the higher-productivity service and industrial sector. On the other hand, it appears that during the decade of the $1950^{\prime}$ 's these rural migrants were essentially sealed off from the industrial sector and channeled in large part into the service sector. (The importance of this to the two-sector formulation of the development process should be noted in passing.) The consequence was a decline 
in income per capita in that sector at the same time that income per capita in the industrial sector was increasing rapidly. This suggests a rather serious imperfection in the labor market which results in a partial frustration of the possibility of growth by the simple transfer of labor from the less productive sector to the more productive sector, and in a failure to share the fruits of the very rapid gain in productivity in the industrial sector.

Although it might be argued that the shift into the service sector is a satisfactory solution, since productivity and income per employed person are higher there than in the agricultural sector, this is clearly a second-best solution. During the decade productivity and income per person were growing rapidly in the industrial sector, and by the end of the decade were much higher than in either the service sector or the agricultural sector. At the same time productivity in the service sector was declining. Moreover, the important point is that the labor was being channeled in large part into the low-productivity component of the service sector, where the decline in productivity was greatest. Hence, the gain in total labor productivity from the labor transfer process is becoming smaller and smaller.

There appear to be a number of possible reasons for what has happened in the labor market. (The explanations must remain tentative because of the absence of sectoral data on capital stock.) These reasons rest ultimately on the measures taken by the government to foster industrialization and on conditions in the labor market per se.

As indicated earlier, Brazil followed an overt policy of import-substitution industrialization in the postwar period. The measures used to implement this policy included high protective tariffs; credit policies which lowered the real price of capital to those investing in the industrial sector; 12 overvaluation of exchange rates, which lowered the relative price of imported capital goods; the use of multiple exchange rates, which discriminated heavily in favor of critical imports needed for industrialization; and a rather broad range of fiscal policies, such as tax holidays or lower rates of taxation for companies that produced import-substitution goods. The consequence of almost all these measures 
was a lowering in the relative price of capital, which provided an incentive to establish a capitalintensive industrial sector.

In addition, it may be that the process of import-substitution industrialization itself had a bias toward capital intensity. If the imports prior to industrialization tended to be capital-intensive because of the relative factor endowments between Brazil and the counties from which it imported, the substitution of imports could have led to the implantation of an industrial sector which was much more capital-intensive than the natural factor endowments would suggest.

And finally, the rapid industrialization led to a borrowing of techniques from the more developed countries, in which relative factor endowments and relative factor prices are quite different. If proportions are relatively fixed once a technique has been adopted, the consequence could be the adoption of factor proportions which are not consistent with existing relative factor prices. However, given the incentives to capital-intensive industrialization discussed above, and the comments which are to follow on the labor market per se, this decision may not have been irrational to the entrepreneur, despite the fact that it was irrational from society's standpoint.

In addition to these factors inherent in the process of industrialization itself, there are a number of factors in the labor market which may have some relevance. These factors amount to an assertion that labor may not be as cheap as it appears to be.

Brazil has labor legislation comparable with that of much more advanced countries. The work rules established by this legislation make the cost of labor much higher than its nominal salary. These include such things as vacations with pay (determined by $(a w)$, and severance pay at the time of firing (based on the length of employment). Fringe benefits such as these, imposed by $l$ aw and more easily policed in the industrial sector, raise the effective cost of labor and encourage economy in its use.

other factors directly in the labor market are the low skill level and the low level of educational attainment of the labor force, particularly of the rural migrants. Educational attainment is in general 
quite low in Brazil. That in the rural sector is even lower relative to the urban sector. (See Chapter 5.113 Consequently, the rural-urban migrant has very few skills and lacks the basic instrument of literacy which would help him acquire basic skills.

The consequence of this is that although labor appears to be abundant, it really isn't. The number of laborers with the skills necessary to work in industry is in fact low. This is perhaps best shown by the relatively large number of ads in sāo Paulo newspapers for skilled labor at the same time that much labor is unemployed.

One possibility, of course, is for the companies to provide the skills themselves, either by paying the tuition for the laborers to attend private or public schools, or by providing on-the-job training. This many of them do. But once again, this raises the cost of the labor and encourages the firm to use a capital-intensive technique of production.

This problem has a number of dimensions. For example, suppose that a firm has the choice between a labor-intensive technique of production using 100 laborers with a medium skill level and a capitalintensive technique that uses only 10 laborers but demands a much higher skill level. If the firm has to provide the skills in any case, it may be less expensive to train the 10 to a higher skill than the 100 to a lower skill level.

\section{SUMMARY}

The performance of the labor market is an important determinant of the well-being of farm people. Because of the relative size of income elasticities of demand for final products, the usual course of development is for a larger and larger fraction of the rural labor force to be transferred to the nonfarm sector. This becomes especially important if there should be technical progress in the agricultural sector, which permits a given agricultural output to be produced with a smaller labor force.

In many respects, the labor market has served the agricultural sector reasonably well in Brazil. Labor has been transferred to the non-farm sector, 
and as a result per capita income in the agricultural sector appears to have risen relative to that in the non-farm sector.

However, the data suggest that serious problems remain in the labor market--problems which could be of increasing importance in the future. In the decade of the $1950^{\prime} \mathrm{s}$, the labor leaving rural areas was channeled in large part into the service sector, with a resulting decline in productivity in that sector. It is not clear how much more labor could be absorbed in that sector. In other words, labor may be locked in the agricultural sector because of a lack of better alternatives, and this at a time when industrial output and productivity are increasing rapidly.

It is important that second-best solutions not be accepted. clearly, agriculture could be the residual employer, since its resources are vast. However, there are many reasons for wanting employment in the agricultural sector to be a small component of the total labor force, since it tends to indicate that the food and fiber needs of the country can be produced by a small labor force, with the bulk of the labor force being used to produce goods associated with a higher standard of living, such as automobiles, television sets, and the other accoutrements of a highly developed economy.

The major policy measures necessary at the present time involve those which will expand employment opportunities in the non-farm sector and will make members of the agricultural labor force more employable. Specific suggestions are as follows:

1. Eliminate the subsidies, both direct and indirect, that have led to capital-deepening in the industrial sector. This does not mean that the country has to abandon its efforts to stimulate a more rapid rate of industrialization. Rather, it means a difference in criteria. Instead of providing subsidies to import-substituting industry, the subsidies should be provided to enterprises that employ relatively more labor. A corollary of this will be the need to encourage exports, since the import-substituting industrialization has taken place in part to eliminate balance of payments difficulties. 
2. Make efforts to lower the cost of labor to the entrepreneur. This will involve a number of measures. The major one will be to increase the level of schooling and training throughout the economy, especially for those components of the labor force that are potential employees in the more productive sectors. This implies a high priority to the provision of technical skills and lower-level education.

One aspect of thig will be the transfer of the costs of such schooling from the private sector to the public sector. It is interesting to note that in Brazil/s, the provision of schooling and training is an economy with as much government intervention as much more of a free-enterprise activity than it is in more advanced countries. Not only technical training, but also lower-level formal schooling, is provided in part through private schools. In addition, much of the cost of such schooling is shared by the labor-using enterprise.

It is generally recognized that because of the relatively large spill-over effects of education, a case can be made for subsidies to this activity in order to obtain the socially optimum rate of investment. It seems clear that increased help from the public sector will not only increase the quantity of schooling and training provided, but also can influence the capital intensity of new enterprise activities, and hence the number of jobs provided.

There is an important side issue in this question of education. The question is often raised as to whether schooling and training should be provided in the rural areas, or whether it might not be more efficient to provide it when the migrant arrives in the city. Two factors argue for the provision of this education in rural areas" (1) it can be provided at an early age, when the opportunity costs to the trainee or student are relatively low; and (2) it will increase the productivity of the labor that does remain in the rural areas.

3. Strengthen the infrastructure of the labor market. There are two dimensions to this:

(a) More research on the labor market itself. It is important to know more about how this market functions, and more about employment needs. and job 
opportunities. Some of this research will have to be fairly basic, while another part will have to be of a more immediate nature. But an increased capacity for research is necessary in order to have an improved public policy.

(b) The provision of an infrastructure which will provide improved market information on the labor market and will help employers and employees get together. This means the implantation of a datagathering capacity on labor market conditions and the installation of employment services on a rather broad scale.

Steps are being taken to improve the reporting of general product market information in Brazil. A corollary of this is to improve the market reporting in the labor market. It will not only help improve individual welfare, but will also help the market to perform more efficiently.

Policy measures such as these will not only make for a wider participation in the fruits of economic progress, an important aspect of political stability, but will also help to make for a more rapid rate of growth in the aggregate. The transfer of laborers from low-productivity employment to high-productivity employment increases output. Perhaps more important, a wider distribution of income will increase the extent of the market and in itself encourage further development.

\section{NOTES}

1. For more details on Brazil's population, see A. H. Neiva, "The Population of Brazil," in J. M. Stycos and J. Airos, eds., Population Dilemma in Latin America (Washington, D.C.: Potomac Books, 1966).

2. CIDA Report, p. 52.

3. For a description of the early migratory processes see Caio Prado, Jr., The Colonial Background of Modern Brazil (Berkeley and Los Angeles: University of California Press, 1967). 
4. For a recent attempt, see Gian 5 . Sahota, "An Economic Analysis of Internal Migration in Brazil," The Journal of Political Economy, LXXVI, 2 (March7Apri1, 1968), 218-245.

5. This can probably be seen more clearly if one considers an alternative way in which the concept can be measured. For example, in Acre in 1940 there were 22,877 foreign-born. This increased to 29,419 in 1950, or a gain of 6,542. But in. 1940 there were 9,852 native-born outside the state, which increased to 13,313 by 1950 , an increase of 3,461 . Thus, 6,542 moved in and 3,461 moved out, for a net gain of 3,081. (The expressions "moved in" and "moved out" must be used advisedly, since we really have no way of knowing how many in fact moved. The concept actually measures the difference between the estimates of a stock concept taken at two different points in time.) It is this process which is implicit in the simple differencing indicated above.

6. Demografia, Diagnostico Preliminar: Plano Decenal de Desenvolvimento Econômico e Social (Rio de Janeiro: IPEA, Ministério de Planejamento, 1966), p. 75 .

7. Sergipe and Bahia, which are classified as in the East in the previous tables, are classified in the Northeast; the Southeast includes Minas Gerais, Espirito Santo, Rio de Janeiro, and São Paulo; and the South includes Parana, Santa Catarina, and Rio Grande do sul.

8. This assumption is questionable, but there are few data to serve as a basis for a better assumption. It is probable that birth rates are higher in rural areas, but the mortality rates are probably higher also. It may be that these cancel out, with the result that our assumption is not too unrealistic.

9. For a rather comprehensive study of the Brazilian labor force, see Maria J. Villaca, A Forca de Trabalho no Brasil (São Paulo: Editora Pioneira Limitado, 1967).

10. Child labor is a much more common phenomenon in Brazil that it is in the more advanced countries. For example, 31 percent of the male population aged 10-14 years were in agricultural, industrial, or 
much of the agricultural sector remains traditionally organized. In many respects it lags behind the total economy, and many would argue that it has been a general brake on the total development.

We don't believe that agriculture can bear such a heavy onus for this. To the contrary, the agricultural sector has performed reasonably well, given the fact that many of the general development policies of the government have discriminated rather heavily against it. Agricultural output has expanded in the aggregate at about the same rate as demand has expanded, and this with little or no rise in relative prices. On the other hand, the agricultural sector could have made a larger contribution to the growth of the general economy had more rational policies been followed.

The present chapter is an analysis of the role of the agricultural sector in the general economy. The labor market aspects of this problem have been discussed. (See Chapter 2.) Here attention is focused on a sectoral breakdown of income and growth rates, on the extent to which agriculture has fed the population at a satisfactory level, the role of agriculture as a source of export earnings, and a general analysis of the contributions of agriculture to the total growth of the economy.

\section{SECTORAL BREAKDOWN OF INCOME AND GROWTH RATES}

Summary data on the distribution of real income by sectors for the period 1940 to 1960 is presented in Table 26. The data show the rather rapid rate at which the economy has expanded over the 20-year period and the more rapid rate of growth of the 1950's.

During the entire period the tertiary, or service sector has been the largest source of income. However, the secondary, or industrial, sector has been expanding at the most rapid rate. As a result of its particularly marked growth during the decade of the 1950's, it had passed the primary sector by 1960 .

The evolution of the net internal product, by major sector, is presented in Table 27. Although all sectors have been expanding at a rather sustained rate, there are differences among them. From 1947 to 1962, the internal product expanded at an average rate of 6 percent a year. On an individual sector 
TABLE 26

Real Income by Sector, 1940, 1950, 1960

$(1953=100)$

\begin{tabular}{lccc}
\hline \multicolumn{1}{c}{ Sector } & 1940 & 1950 & 1960 \\
\hline & & (million NCr\$) & \\
Agriculture & 79.3 & 95.2 & 146.3 \\
Industry & 34.8 & 72.5 & 173.2 \\
Service & 86.8 & 146.8 & 239.8 \\
$\quad$ Commerce & --- & 42.1 & 80.0 \\
$\begin{array}{l}\text { Transportation, } \\
\text { Communication }\end{array}$ & --- & 20.8 & 42.1 \\
$\begin{array}{l}\text { Government, } \\
\text { Personal Services }\end{array}$ & --- & 83.7 & 115.3 \\
$\begin{array}{l}\text { Total } \\
\text { Total }\end{array}$ & 201.1 & 314.5 & 558.3 \\
\hline
\end{tabular}

Source: 1940 from Projeções de oferta e Demanda de Produtos Agrícolos para o Brasil (Rio de Janeiro: IBRE, FGV, Centro de Estudos Agrícolos, 1966), p. 54; 1950 and 1960, synthesized from the national accounts. 
TABLE 27

Indexes and Percentage Changes in Net Internal Product, 1947-1967 $(1953=100)$

\begin{tabular}{|c|c|c|c|c|c|c|c|c|}
\hline & $\begin{array}{l}\text { Total } \\
\text { Index }\end{array}$ & $\begin{array}{l}\text { Economy } \\
\text { Percent } \\
\text { Change }\end{array}$ & $\begin{array}{l}\text { Primary } \\
\text { Index }\end{array}$ & $\begin{array}{l}\text { Sector } \\
\text { Percent } \\
\text { Change }\end{array}$ & $\begin{array}{l}\text { Seconda } \\
\text { Index }\end{array}$ & $\begin{array}{l}\text { Sector } \\
\text { Percent } \\
\text { Change }\end{array}$ & $\begin{array}{l}\text { Tertic } \\
\text { Index }\end{array}$ & $\begin{array}{l}y \text { Sector } \\
\text { Percent } \\
\text { Change }\end{array}$ \\
\hline $\begin{array}{l}1947 \\
1948 \\
1949 \\
1950 \\
1951 \\
1952 \\
1953 \\
1954 \\
1955 \\
1956 \\
1957 \\
1958 \\
1959 \\
1960 \\
1961 \\
1962 \\
1963 \\
1964 \\
1965 \\
1966 \\
1967 \mathrm{a}\end{array}$ & $\begin{array}{r}71.9 \\
78.7 \\
83.1 \\
87.3 \\
91.8 \\
96.9 \\
100.0 \\
107.7 \\
115.0 \\
117.2 \\
125.2 \\
133.6 \\
143.4 \\
153.0 \\
164.1 \\
172.9 \\
175.6 \\
181.1 \\
188.1 \\
194.4 \\
204.0\end{array}$ & $\begin{array}{l}-- \\
9.4 \\
5.6 \\
5.1 \\
5.1 \\
5.5 \\
3.0 \\
7.7 \\
6.7 \\
1.9 \\
6.9 \\
6.6 \\
7.3 \\
6.7 \\
7.3 \\
5.4 \\
1.6 \\
3.1 \\
3.9 \\
3.3 \\
4.9\end{array}$ & $\begin{array}{r}80.1 \\
85.7 \\
89.5 \\
90.0 \\
91.5 \\
99.8 \\
100.0 \\
107.9 \\
116.2 \\
113.4 \\
124.0 \\
126.5 \\
133.2 \\
139.7 \\
150.3 \\
158.5 \\
158.7 \\
160.9 \\
184.7 \\
174.8 \\
187.2\end{array}$ & $\begin{array}{r}-- \\
6.9 \\
4.4 \\
1.6 \\
.6 \\
9.0 \\
.2 \\
7.9 \\
7.7 \\
2.5 \\
9.3 \\
2.0 \\
5.3 \\
4.9 \\
7.6 \\
5.5 \\
.1 \\
1.4 \\
14.7 \\
-5.4 \\
7.1\end{array}$ & $\begin{array}{r}66.2 \\
67.0 \\
74.0 \\
82.4 \\
87.6 \\
92.0 \\
100.0 \\
108.5 \\
120.0 \\
128.3 \\
135.5 \\
157.7 \\
178.0 \\
195.9 \\
217.0 \\
233.7 \\
235.3 \\
247.1 \\
235.4 \\
263.2 \\
270.7\end{array}$ & $\begin{array}{r}-- \\
11.2 \\
10.4 \\
11.3 \\
6.3 \\
5.0 \\
8.6 \\
8.5 \\
10.5 \\
6.9 \\
5.3 \\
16.4 \\
12.9 \\
10.1 \\
10.8 \\
7.7 \\
.7 \\
5.0 \\
-4.7 \\
11.8 \\
2.8\end{array}$ & $\begin{array}{r}74.6 \\
81.3 \\
84.5 \\
88.1 \\
94.3 \\
97.9 \\
100.0 \\
107.3 \\
111.2 \\
113.3 \\
120.6 \\
125.4 \\
132.5 \\
141.0 \\
148.6 \\
154.6 \\
159.6 \\
164.6 \\
170.1 \\
177.6 \\
186.6\end{array}$ & $\begin{array}{l}-- \\
9.0 \\
3.9 \\
4.3 \\
7.0 \\
3.8 \\
2.1 \\
7.3 \\
3.6 \\
1.9 \\
6.4 \\
4.0 \\
5.7 \\
6.4 \\
5.4 \\
4.0 \\
3.2 \\
3.1 \\
3.3 \\
4.4 \\
5.1\end{array}$ \\
\hline
\end{tabular}

apreliminary.

Source: Total, primary, and secondary figures are taken from the national accounts as reported by $C C N$, IBRE, FGV. The data for the tertiary sector are synthesized from the national account data, using as weights the shares of each subsector of the tertiary sector in national income for 1950 and 1960 . 
basis, however, the rates were as follows: primary, 4.7 percent; secondary, 9.5 percent; and tertiary, 5.1 percent.

As a result of these differential rates of growth the agricultural sector declined from 32.4 percent of the total in 1947 to 26.6 percent in 1962 , and the service sector declined from 47.1 percent of the total to 40.2 percent in the same interval, as shown in Table 28. The secondary, or industrial, sector, on the other hand, expanded from 20.5 percent in 1947 to 33.2 percent in 1962.

In the 1963-1967 period, the internal product expanded at the much lower rate of 3.3 percent per year. On a sectoral basis, the primary sector expanded at an average rate of 3.6 percent a year in this period, the secondary sector at an average rate of 3.1 percent, and the service sector at a rate of 3.8 percent a year. As a result of these differences in growth rates, both the primary and service sectors grew in relation to the secondary sector in this latter period.

The service sector remains the largest single component of the economy, even though it has declined in relative importance over time. The industrial sector passed the agricultural sector in 1958, and continued to expand relatively up through 1964 .

A longer-run perspective on the respective growth rates between agriculture and industry can be found in Table 29. In the period from 1920 to 1940 , the two sectors grew at about the same rate. From 1940 to 1960, however, the industrial sector grew at a much more rapid rate. Agricultural output grew slowly in the decade of the 1940's and increased its rate of growth in the $1950^{\prime} \mathrm{s}$.

Data on the sectoral growth per capita are given in Table 30. The most striking phenomena here, perhaps, are the rather sustained rate of increase in per capita production in the total economy and the rapid rate of growth, on a per capita basis, of industrial production. The low rate of growth of the agricultural sector in the $1940^{\prime}$ 's resulted in declining per capita production. In the 1950's, however, agricultural production per capita rose. 
TABLE 28

Real Internal Product, by Sector, 1947-1965

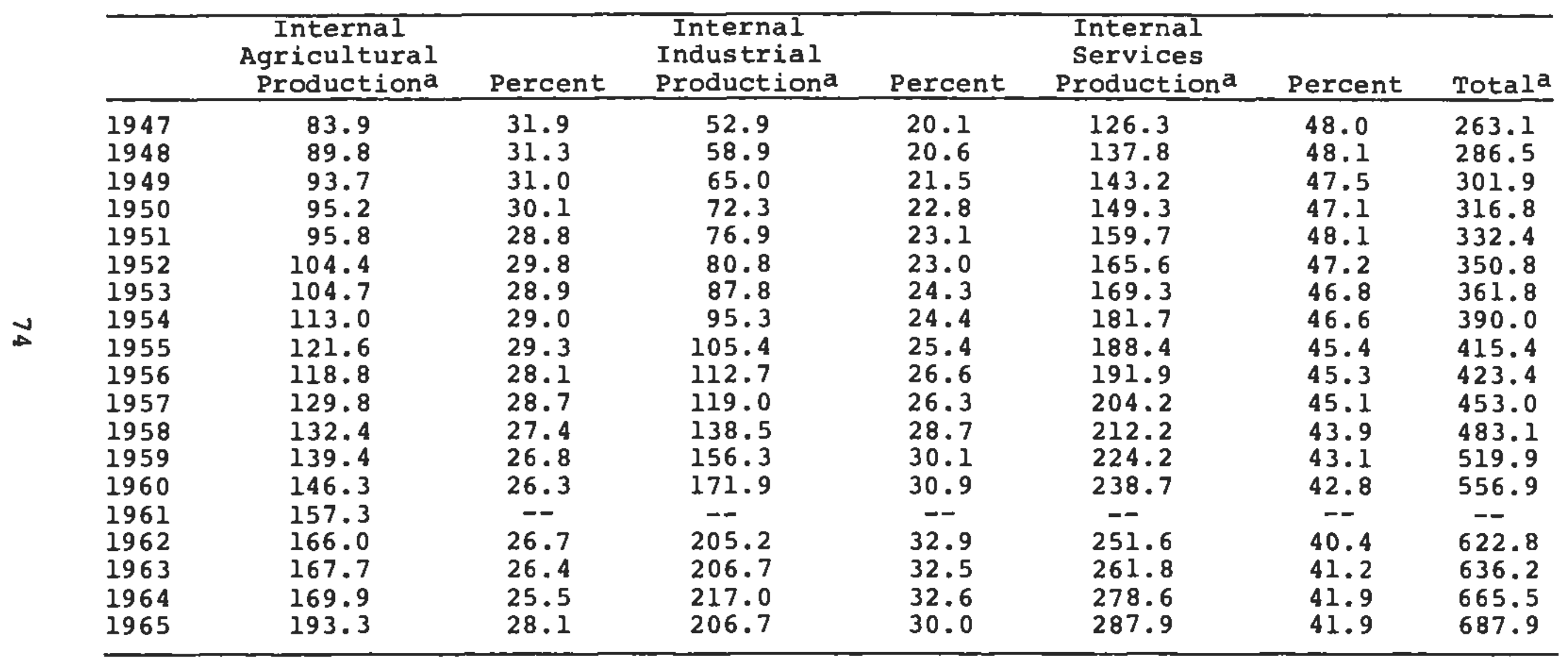

$a_{\text {million NCr\$, } 1953 .}$

Source: Synthesized from data reported by CCN, IBE, FGV. 
Rate of Growth, Agricultural and Industrial Sectors, 1920-1962

\begin{tabular}{|c|c|c|c|c|}
\hline sector & $\begin{array}{c}1920-1922 \\
\text { to } \\
1930-1932\end{array}$ & $\begin{array}{c}1930-1932 \\
\text { to } \\
1940-1942\end{array}$ & $\begin{array}{c}1940-1942 \\
\text { to } \\
1950-1952\end{array}$ & $\begin{array}{c}1950-1952 \\
\text { to } \\
1960-1962\end{array}$ \\
\hline Agriculture & 2.9 & 6.3 & 1.4 & 4.7 \\
\hline Industry & 2.7 & $\underline{6.0}$ & 7.7 & 8.9 \\
\hline Total & 3.1 & 6.2 & 4.8 & 6.0 \\
\hline
\end{tabular}

Source: $\mathrm{CCN}, \mathrm{IBRE}, \mathrm{FGV}$.

TABLE 30

Sectoral Growth per Capita, 1920-1962

\begin{tabular}{|c|c|c|c|c|c|}
\hline Sector & $\begin{array}{l}1920 \\
\text { to } \\
1960\end{array}$ & $\begin{array}{c}1920-1922 \\
\text { to } \\
1930-1932\end{array}$ & $\begin{array}{c}1930-1932 \\
\text { to } \\
1940-1942\end{array}$ & $\begin{array}{c}1940-1942 \\
\text { to } \\
1950-1952\end{array}$ & $\begin{array}{c}1950-1952 \\
\text { to } \\
1960-1962\end{array}$ \\
\hline Agriculture & 2.0 & 1.4 & 4.8 & -0.9 & 1.7 \\
\hline Industry & 4.2 & $\underline{1.2}$ & 4.5 & 5.3 & 5.9 \\
\hline Total & 3.8 & 1.6 & 4.7 & 2.4 & 3.0 \\
\hline
\end{tabular}

Source: A Indústria de Alimentos no Brasil (Rio de Janeiro: CCN, IBTR, FGV, 1966). 
These data mask some important details, however. For example, the rapid increase in agricultural production indicated in the decade of the 1930's reflects a rapid increase in the production of extractive plant products in the latter part of this period. More specifically, it reflects the large increase, early in World War II, in the production of firewood and vegetable charcoal as replacements for liquid combustibles. In addition to this problem, the role of production for exports must be considered.

Table 31 presents data on the disaggregation of the agricultural production and compares it with the rate of population increase. In the decade of the 1920's, almost all of the components grew at a rate greater than the rate of population increase. Production for the internal market grew at an especially high rate.

In the decade of the 1930's it is clear that the large rate of growth in total agricultural production was due in large part to the production of extractive products--the aforementioned production of firewood and vegetable charcoal. Production for the internal market in this period declined absolutely, and hence at an even greater rate on a per capita basis. The decline in production for export was equally serious. In total, if the category of extractive plant products is eliminated, agricultural production grew at a rate of only 1 percent a year in this interval.

Total agricultural production grew at a rate less than the rate of population increase in the $1940^{\prime} \mathrm{s}$. The production of crops for the internal market grew at a rate lower than the rate of population increase, although the production of animal products grew at a higher rate. The latter are relatively less important in Brazilian diets, however. Production for export grew at a substantially higher rate in this decade.

The agricultural sector expanded vigorously in the decade of the 1950's. Per capita rates rose for all categories except export. The production for the internal market grew at a relatively high rate.

These data, of course, still do not tell the whole story about the trends in per capita 
TABLE 31

Growth Rates of Agricultural Production and Population, 1920-1962 (annual geometric rate)

\begin{tabular}{|c|c|c|c|c|}
\hline & $\begin{array}{c}1920-1922 \\
\text { to } \\
1930-1932\end{array}$ & $\begin{array}{c}1930-1932 \\
\text { to } \\
1940-1942\end{array}$ & $\begin{array}{c}1940-1942 \\
\text { to } \\
1950-1952\end{array}$ & $\begin{array}{c}1950-1952 \\
\text { to } \\
1960-1962\end{array}$ \\
\hline Agricultural Production & 2.9 & $6 \cdot 3^{a}$ & 1.4 & 4.7 \\
\hline Crops & 3.5 & 1.1 & 2.0 & 4.9 \\
\hline Export products & 2.1 & 0.1 & 4.1 & 2.3 \\
\hline $\begin{array}{l}\text { Products for internal } \\
\text { market }\end{array}$ & 5.1 & -0.4 & 1.0 & 5.4 \\
\hline $\begin{array}{l}\text { Animal Products, } \\
\text { Derivatives }\end{array}$ & 1.4 & 0.6 & 2.6 & 4.2 \\
\hline Extractive Plant Products & $\underline{4.8}$ & 23.1 & $\underline{0.5}$ & 5.9 \\
\hline Population & 1.5 & 1.5 & 2.4 & 3.0 \\
\hline
\end{tabular}

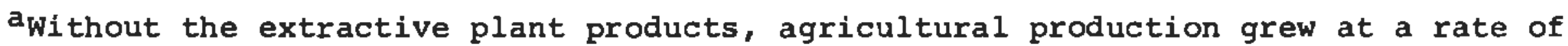
only 1 percent.

Source: A Indústria de Alimentos no Brasil (Rio de Janeiro: IBRE, FGV, 1966). 
consumption. Being Basically production data, they provide little insight into what fraction is actually reaching the consumer (the loss between producer and consumer is estimated at around 30 percent), or about the distribution of the production among the several income classes.

Estimates are available in Table 32 of the per capita food consumption for the period 1950-1964. over that period per capita food consumption rose 22.3 percent, or 1.6 percent a year. Per capita consumption probably expanded substantially in 1965 , declined somewhat in 1966 , and increased again in 1967.

\section{NUTRITION}

The degree of malnutrition or the adequacy of the diet in Brazil is a very controversial question. Research on the subject is quite limited, and that available by no means provides consistent answers. The issue is quite sensitive from a political standpoint, and care must be exercised in interpreting official government statistics.

Some data will be presented in this section on the general magnitude of the problem. 1 Beyond that, however, we present our judgment of both the magnitude and the characteristics of the problem. This is a problem that needs a great deal more research, and more attention from government policy makers.

From a caloric standpoint, the supply of food appears, on the average, to be adequate. official statistics suggest that Brazil's agriculture provided its population with an estimated, 2,780 to 3,000 calories per person per day in 1960. If true, this would make Brazil the second-best-fed nation in Latin America; 2 and it would indicate that there exists a significant excess of calories over basic requirements, which have been estimated by one Brazilian source to be 2,275 calories per day per person.

The CIDA report questions the accuracy of these official statistics and points out that they tend to be higher than comparable FAO estimates. 3 They suggest that the daily calorie intake per person 


\section{TABLE 32}

Real Growth in per Capita Food Consumption, 1950-1964

\begin{tabular}{lcc}
\hline Year & Index & Annual Change \\
\hline 1950 & 100.0 & -- \\
1951 & 100.3 & 0.3 \\
1952 & 101.9 & 1.6 \\
1953 & 107.6 & 5.6 \\
1954 & 112.1 & 4.2 \\
1955 & 109.7 & -2.1 \\
1956 & 113.9 & 3.8 \\
1957 & 113.9 & 0.0 \\
1958 & 109.9 & -3.5 \\
1959 & 115.7 & 1.6 \\
1960 & 119.9 & 3.6 \\
1961 & 119.0 & -0.6 \\
1962 & 121.9 & 2.4 \\
1963 & 122.5 & 0.5 \\
1964 & 122.3 & -0.2 \\
\hline
\end{tabular}

Source: A Indústria de Alimentos no Brasil (Rio de Janeiro: IBRE, FGV, 1966), p. 13. 
probably did not exceed 2,670 in 1960 . This estimate includes imported foods (almost entirely wheat) at the rate of about 300 calories per person per day, or about 10-11 percent of the total. It is interesting to note that this is still above the minimal requirement cited above.

There appear to be more serious problems when one considers the quality of the diet, however. Diets appear to be deficient in fats and in the quality of the protein. A large fraction of the protein comes from plant sources. The degree of deficiency depends, of course, on the assumptions that one makes about the requirements for an adequate diet. Table 33 summarizes some estimates of the surpluses or deficits of food nutrients for three levels of calorie requirements, on the basis of total supplies of nutrients available in 1960 , both including and excluding imported foods. 4 These data indicate a general problem of obtaining more proteins and fats in the diet.

Projected food budgets are also available for 1970. An example of these is presented in Table 34. These projections are based on patterns of land use that are similar to those of the past and on a continuation of past trends in the production of crops and livestock. The data suggest an improvement in the qualitative aspects of the food supplies, depending on the calorie requirement used, but that the aggregate dietary aspects of food consumption would not change significantly. Note that the per capita supply of calories for 1970 is at a fairly high level if imports are included, but that this requires a fairly substantial drain on foreign exchange.

of course, none of this has anything to say about other aspects of nutrition, such as the intake of vitamins and minerals and eating habits. The Brazilian diet tends to be limited in fresh or green vegetables, but rather high in fruits, especially tropical fruits such as bananas and oranges. -To what extent these provide balance in these other dimensions is unknown.

The aggregate data on nutritional deficits and surpluses ignore another important dimension of the problem. This has to do with the very unequal distribution of income in Brazil. It is our judgment 
Estimated Surpluses and Deficits of Food Nutrients, 1960 (million tons per year)

\begin{tabular}{ccccccc}
\hline $\begin{array}{c}\text { Calorie } \\
\text { Requirement }\end{array}$ & $\begin{array}{c}\text { Deficits or Surpluses } \\
\text { Excluding }\end{array}$ & $\begin{array}{c}\text { Importsa } \\
\text { Carbohydrates }\end{array}$ & Proteins & Fats & Carbohydrates & $\begin{array}{c}\text { Deficits or Surpluses } \\
\text { Includingorts }\end{array}$ \\
\hline 2,275 & 2.54 & -.22 & -.43 & 4.12 & .04 & -.39 \\
2,780 & .52 & -.65 & -.80 & 2.10 & -.39 & -.76 \\
$3,272^{\mathrm{C}}$ & -1.72 & -1.44 & -.82 & -.15 & -1.18 & -.83 \\
\hline
\end{tabular}
in 1960 .

actual supplies of nutrients without imports $=2,496$ calories per person per day, 1960 .

b Actual supplies of nutrients with imports $=2,780$ calories per person per day, in

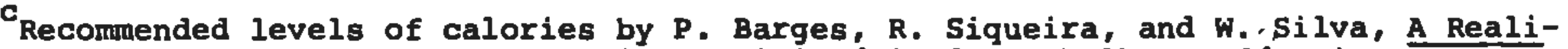
dade Alimenta Brasileira (Rio de Janeiro: Ministério de Trabalho, Indústria e Comercio, Serviço de Documentagão, 1957), Chapter IV, p. 102.

Source: Estimates by M. L. Rodrigues de Almeida, "A Task for Brazilian Agriculture: Some Aspects of the Gap Between Actual Consumption and That Based on an Adequate Diet in 1960 and 1970." 
TABLE 34

Surpluses and Deficits of Food Nutrients, 1970

(million tons per year)

\begin{tabular}{ccccccc}
\hline $\begin{array}{c}\text { Calorie } \\
\text { Requirement }\end{array}$ & $\begin{array}{c}\text { Deficits or Surpluses } \\
\text { Excluding }\end{array}$ & $\begin{array}{c}\text { Imports } \\
\text { Proteins }\end{array}$ & Fats & Carbohydrates & $\begin{array}{c}\text { Deficits or Surpluses } \\
\text { Including } \\
\text { Imports } \\
\text { Proteins }\end{array}$ & Fats \\
\hline 2,275 & 5.57 & .20 & -.30 & 8.13 & .42 & -.28 \\
2,780 & 2.87 & -.55 & -.80 & 5.42 & -.15 & -.78 \\
3,272 & -.15 & -1.62 & -.88 & 2.40 & -1.22 & -.86 \\
\hline
\end{tabular}

Note: The available supply of calories for 1970 was estimated at 3,185 with imports and 2,840 without imports.

Source: Estimates by M. L. Rodrigues de Almeida, "A Task for Brazilian Agriculture: Some Aspects of the Gap Between Actual Consumption and That Based on an Adequate Diet in 1960 and 1970." 
that the low-income classes, especially those in the rural areas of the interior and those in the large urban slums, have very deficient diets. Again, little or no research has been done on this, but a study made in Alagoas, in the Northeast, showed that the proletarian class consumed 1,840 , the mediun class 2,527, and the well-off class 3,006 calories daily per person. 5 This is clearly deficient for the low-income class.

Moreover, the diets of the low-income classes tend to be very low in protein, particularly animal protein. Many families are lucky to have meat with one meal a week, and per capita production of dairy products is quite low compared with other countries. The high infant mortality rate in the interior of Brazil is attributed in large part to dietary deficiencies.

In summary, then, it is our judgment that the nutritional problem in Brazil is not a question of total food production. The problem is basically one of a very highly skewed income distribution, lack of knowledge about dietary requirements and ways of meeting them, and the qualitative aspects of the diet. In the latter case, the major problem appears to be the lack of animal protein, although serious vitamin and mineral deficiencies may also exist.

Many dimensions of this problem are beyond the reach of agriculture and agricultural policy. Perhaps the most important need is research which verifies the dietary needs of people in tropical countries and the nutrient content of the major food items. Special attention should be given in this research to the adequacy of protein from the plant sources used in Brazil. Once the stock of knowledge concerning these factors is increased, education becomes the major policy variable.

However, agricultural policy can contribute to an alleviation of some of the distributional problems. It is unfortunate that the distributional effects associated with a modernizing agriculture are frequently ignored. The modernization of agriculture, with its consequent reduction in real food prices, is a distribution of the fruits of technical progress in favor of the low-income classes. The consumer will benefit in proportion to the fraction 
of his budget spent on rood products, and low-income puople typically spend the major fraction of tholr budgut on this item.

Honce, a policy of modornizing agriculturo will holp both in alloviating the highly skuwd incoms digtribution in the country and, in addition, will alleviate somewhat the nutritional problems associated with low incomos. If, in addition to this, some attention is givon to modernizing the production of animal products, so that these become available to low-income poople oven with their serious budget constraints, an additional contribution can be made. This seoms to be an especlally rolevant consideration because total food production does not seem to be as much a problem as is the quality of the diet.

\section{AGBICULTURE AS A SOURCE OF EXPORT EARNINGS}

Agricultural products have made up roughly 80 percent of Brazilian exports for a long period of time. Coffee, of course, has been the major export earner, although cotton, cocoa, and cane gugar have also been important.

Braxil has a long history of first being the dominant world producer of a given product, and then seeing its position eroded by stronger competition in other parts of the world. This has been the case with sugar in the lath century, rubber, cocoa, and now coffee.

The reasons for this are at least twofold. One problem has been the failure to modernize the production of export products. Even in products for which Brazil has a natural comparative advantage, other countries have taken itg markets by adopting a higher level of technology. Notable examples are sugar (under the Dutch occupation of the Northeast), rubber, and, more recently, cocoa. The cocoa zone of Bahia remains one of the most traditional farming areas of Brazil, while Ghana and other countries penetrate the market by adopting quite high levels of technology.

Thls problem has been compounded by unfortunate economic policles. There are three dimensions to 
this. One $1 \mathrm{~s}$ the tenuency to restrlet marketings in ordur to ralue world pricus, guch as was done with coftee and, to a losper extent, with cocoa. This provides an umbrella and an incentive for producers in other parts of tho world to start production. If they ontur with a new, highor level of tochnology, the competition soon becomes strong, and this $1 \mathrm{~s}$ compounded by a general problom of excess production as a rosult of supporting prices above the equilibrium level.

Tho second problem is more a consequence of domestic pollcies. For example, Brazil for a long perlod of time tried to hold sugar production in the North, desplte tho obvious comparative advantage of the solls and climate in the south. The reason for this was the eerlous regional income problem that would have resulted had the production moved to the South. Partly as a result of thlo policy, lmportant world markets were lost. A more rational policy would have been to deal with the reglonal problem in a more direct way, and to capitalize on the comparative advantage that the South had.

The third problem $1 \mathrm{~s}$ the negative view that pollcy makers have taken towards exports. It seems to have been assumed that an 1mport-gubstitution industrialization policy would simultaneously provide an engine of growth for the economy and oolve the recurrent balance of payments problems. For this reason, little or no attempt was made to stimulate exports. On the contrary, the combination of a greatly overvalued exchange rate and export licensing provisions discriminated heavily agalnst the export sector.6 Agriculture suffered especially severely as a result of these pollcies.

Data on exports in the most recent elght-year perlod are given in Table 35. The exports have been divided into traditional and non-traditional categories. Brazilian exports have been relatively atagnant throughout the postwar period, a time when world trade has been increasing. It 1 s intereating to note that the increase since 1965 has been largely in non-traditional exporta.

The role that coffee has played as an exchange earner can clearly be seen. Had a more aggressive marketing pollcy been followed in recent years, exchenge earnings could probably have been larger. 
TABLE 35

Brazilian Exports (FOB), 1960-1967

(million U.S.S)

\begin{tabular}{|c|c|c|c|c|c|c|c|c|}
\hline & 1960 & 1961 & 1962 & 1963 & 1964 & 1965 & 1966 & 1967 \\
\hline $\begin{array}{l}\text { Coffee } \\
\text { Cotton } \\
\text { Cocoa } \\
\text { Sugar } \\
\text { Iron ore } \\
\text { Manganese }\end{array}$ & $\begin{array}{r}713 \\
46 \\
98 \\
58 \\
53 \\
30 \\
\end{array}$ & $\begin{array}{r}710 \\
110 \\
62 \\
66 \\
60 \\
32 \\
\end{array}$ & $\begin{array}{r}643 \\
112 \\
40 \\
40 \\
68 \\
27 \\
\end{array}$ & $\begin{array}{r}748 \\
114 \\
50 \\
72 \\
70 \\
24 \\
\end{array}$ & $\begin{array}{r}760 \\
112 \\
46 \\
33 \\
81 \\
21 \\
\end{array}$ & $\begin{array}{r}707 \\
101 \\
41 \\
57 \\
103 \\
29 \\
\end{array}$ & $\begin{array}{r}764 \\
111 \\
51 \\
81 \\
100 \\
27 \\
\end{array}$ & $\begin{array}{r}705 \\
91 \\
59 \\
80 \\
103 \\
14 \\
\end{array}$ \\
\hline exports & 998 & 1,040 & 930 & 1,078 & 1,053 & 1,038 & 1,134 & 1,052 \\
\hline $\begin{array}{l}\text { Meat } \\
\text { Manufactures } \\
\text { Machinery } \\
\text { Other }\end{array}$ & $\begin{array}{r}4 \\
5 \\
2 \\
261 \\
\end{array}$ & $\begin{array}{r}8 \\
11 \\
342 \\
\end{array}$ & $\begin{array}{r}6 \\
6 \\
12 \\
251 \\
\end{array}$ & $\begin{array}{r}6 \\
10 \\
11 \\
301 \\
\end{array}$ & $\begin{array}{r}23 \\
34 \\
18 \\
302 \\
\end{array}$ & $\begin{array}{r}47 \\
66 \\
29 \\
415 \\
\end{array}$ & $\begin{array}{r}32 \\
38 \\
33 \\
504 \\
\end{array}$ & $\begin{array}{r}22^{a} \\
70 \\
44 \\
466 \\
\end{array}$ \\
\hline exports & 272 & 365 & 275 & 328 & 377 & 557 & 607 & 602 \\
\hline Total exports & 1,270 & 1,405 & 1,205 & 1,406 & 1,430 & 1,595 & 1,741 & 1,654 \\
\hline
\end{tabular}

$a_{\text {Estimated by the author. }}$

Source: Superintendência da Moeda e do Crédito (SUMOC), Relatório 1964; Anuário Estatistico do Brasil 1967 (Rio de Janeiro: IBGE, 1968); Relatorrio do Banco do Brasil 1967. 
For example, in 1964 Brazil's coffee exports fell $3.9 \mathrm{million}$ bags short of its allowable quota for the year. It appears that the country continued its policy of bolstering the world market price by restricting supply. The result is that its share of the world coffee market suffered inroads from the ecompetition of other coffee producers. From a historical standpoint, Brazil was probably wise in exploiting its monopoly position as a coffee supplier through restrictions on marketings. However, once production had been stimulated in other parts of the world, the demand for Brazilian coffee was no larger inelastic, despite the fact that the final demand for coffee was. When these conditions had changed, the policy should have changed to one of agressive marketing and price competition.

Perspective on the longer-term problems of the coffee sector can be gained from data presented in Tables 36 and 37. Two factors are important. One is the secular decline in price received for the product. The other is the very substantial withholdings from the market. In the four-year period of 1959-1962, literally half of the production was held off the world market and placed in storage.

Coffee prices recuperated strongly in 1964, and were as high as they have been since 1958 . They continued strong into 1965 also, a factor which helped Brazil keep its exchange earnings up. Perhaps the recent world accord will provide stability in this market, but it does not bode well for substantially increasing the earnings from this product.

Returning to Table 35 , it can be seen that cotton was Brazil's second most important export in most of the $1960^{\prime} \mathrm{s}$. It replaced cocoa in the early $1960^{\prime} \mathrm{s}$, and has alternated with exports of iron ore in recent years as the second largest source of exchange earnings.

Cocoa export earnings have continued to decline, although there was some recuperation in 1966 and 1967. Cocoa prices in the world market have been depressed, and the productivity of the Brazilian cocoa sector continues to decline. This decline in productivity is in part due to the aging of the trees and a low level of technology, and in part due to a series of bad climatic conditions. For example, in 
TABLE 36

Coffee Sector's Earning Capacity, 1953-1961

\begin{tabular}{|c|c|c|c|}
\hline Year & $\begin{array}{c}\text { Average Value } \\
\text { per Bag } \\
(\mathrm{U} . \mathrm{S. \$}) \\
(1953=100)\end{array}$ & $\begin{array}{c}\text { Cr\$ Earnings } \\
\text { per } 10 \mathrm{~kg} \cdot \\
\text { Santos no. } 4 \\
\text { Coffee } \\
(1953=100)\end{array}$ & $\begin{array}{l}\text { Cr\$ Earnings } \\
\text { Index Deflated } \\
\text { by Cost of } \\
\text { Living Index } \\
(1953=100)\end{array}$ \\
\hline 1953 & 100 & 100 & 100 \\
\hline 1954 & 123 & 185 & 151 \\
\hline 1955 & 87 & 180 & 119 \\
\hline 1956 & 87 & 192 & 95 \\
\hline 1957 & 83 & 194 & 92 \\
\hline 1958 & 76 & 208 & 86 \\
\hline 1959 & 60 & 198 & 59 \\
\hline 1960 & 61 & 242 & 55 \\
\hline 1961 & 60 & 313 & 54 \\
\hline
\end{tabular}

Source: Werner Baer, Industrialization and Economic Development in Brazil (Homewood, Ill.: Richard D. Irwin, Inc., 1965). 
TABLE 37

Coffee Production and Exports $(1,000$ metric tons $)$

\begin{tabular}{ccccc}
\hline \multirow{2}{*}{ Year } & \multicolumn{2}{c}{$\begin{array}{c}\text { Production } \\
\text { Quantity }\end{array}$} & \multicolumn{2}{c}{ Exports } \\
Quantity & Index \\
\hline $1948 / 1949-1953 / 1954$ & & & & \\
Yearly average & $1,076.6$ & 100 & $1,006.5$ & 100 \\
$1959 / 1960$ & $2,628.9$ & 244 & $1,046.2$ & 104 \\
$1960 / 1961$ & $1,796.6$ & 167 & $1,009.1$ & 100 \\
$1961 / 1962$ & $2,085.0$ & 194 & $1,018.2$ & 101 \\
\hline
\end{tabular}

Source: Werner Baer, Industrialization and Economic Development in Brazil (Homewood, III.: Richard D. Irwin, Inc., 1965).

1966, with world prices up and good weather in the early part of the season, prospects were excellent; but a series of rains in the harvesting season led to serious disease damage. Brazilian exports in 1964 were adversely affected by adherence, long after other signatories to an agreement among major producers to keep cocoa off the market in an unsuccessful attempt to maintain prices.

Sugar is the remaining important agricultural export. After rather poor years in 1962 and 1964, sugar exports expanded substantially in 1966 and 1967. In both years they were the third most important agricultural export.

As a final note on agricultural exports, it should be noted that exports of meat, a non-traditional export, increased substantially in 1964 and 1965. This came about partly through the relaxation of embargos on the export of food products. After a decline in 1966, meat exports again expanded in 1967.

Imports of food by Brazil have never been large, although crises in individual items has been alleviated by temporary imports. Food imports have 
consisted primarily of wheat and other products which are not climatically adapted to Brazil.

Food imports increased markedly in 1964, but this was primarily an attempt to offset the effects of two successive bad crop years. This took the form of greatly increased wheat imports from Argentina and the U.S., the latter largely under PL 480. In $1965 \mathrm{im}-$ ports, particularly wheat, declined substantially as a result of the improved crop year and the elimination of import subsidies on wheat.

\section{AGRICULTURAL EXPORT POTENTIAL}

If Brazil's proposed development programs are successful, balance-of-payment problems are likely to be persistent. The need to expand exports will be great. The following analysis will show that the potential for expansion of the traditional Brazilian exports is not bright, and that greater promise rests in expanding non-traditional exports. However, a more aggressive export policy and the pursuit of an appropriate exchange rate policy can lead to increased exports, and at the same time increase income in the agricultural sector.

The following in a product-by-product summary of export prospects for agricultural products:

\section{Coffee}

The International coffee Agreement is attempting to establish some order in the world market for coffee and to prevent the large gyrations of the past. Success with the Agreement will remove the onus from Brazil of withholding supplies from the market to support world prices. On the other hand, the Agreement is likely to "institutionalize" existing production patterns, with shares of the market determined by existing rates of participation rather than by comparative advantage. This implies that the external market for Brazilian coffee will likely expand about in accord with world demands, with little potential for earning a larger share of the market. It should be noted, however, that Brazil has not been utilizing its full quota under the Agreement. 
The Brazilian government has recognized this problem and is making serious attempts to cut back coffee production and diversify agricultural production. Two major policies have been followed. First, the price the farmer received for coffee was being held relatively constant at the same time that inflation continued at roughly 40-50 percent a year. This resulted in a serious decline in the relative price of coffee and created income problems in the areas of intensive production. Coincidental with this, another government agency, GERCA (Executive Group for the Rationalization of Coffee Production) has been subsidizing the destruction of coffee plantings and financing the transfer of land to other lines of production. Incidental to these two programs of action, prices of other agricultural products were freed up in 1966, which provided further incentive to change production patterns.7

Sugar

The outlook for this product will depend in part on actions of the U.S. Congress in determining import quotas. It would not appear to offer great potential for expansion, although a gradual increase is possible, especially if a more rational exchangerate policy is followed.

\section{Cotton}

Production in Brazil has been growing at a steady pace. However, increasing production is a worldwide trend; and some countries, especially the U.S., have improved their competitive position. Moreover, synthetics are always a threat. Brazil will probably do well to maintain its current level of exports.

\section{Cocoa}

Until recently the second most important export earner for Brazil, this product has suffered serious problems in recent years. As a result of a protective umbrella on world prices maintained through marketing restrictions, world cocoa production increased at a rapid rate. These new plantings, with their relatively high level of technology, have taken the comparative advantage away from Brazil. At the same time that world prices have been depressed as a result of increased production, 
Brazilian production has declined, partly as a result of a series of years of unfavorable weather. Action is now being taken to improve Brazilian cocoa production, but this will require many years, since it is a tree corp

Improved weather and world market conditions could provide some increase in export earnings in the near future. Over the longer pull, this crop does have considerable potential because of the inherent comparative advantage that the production area in Brazil offers and the rising demand that comes with rising per capita income levels. To realize this potential, however, the cocoa zone will have to be modernized. This includes not only the level of technology and management on the farms, but also a more modern transportation network and handing facilities in the port. A federal agency, CEPLAC (Comissão Executiva, Plano de Recuperação Éconómica Rural da Lavoura Cacaueira), has been given responsibility for modernizing this sector. It is undertaking an extensive research program, as well as making attempts to improve the physical infrastructure. It will require some time before these efforts can have a significant effect, however.

\section{Other Agricultural Products}

The potential for a number of non-traditional export products would appear to be good. The elimination of restrictions on meat exports has opened a possibility for Brazil to take advantage of the very important resource which it has in its cattle herd. To fully realize this, however, the level of efficiency in the livestock production industry will have to be raised considerably. In addition, expansion of the meat-packing industry will be necessary.

It would appear that the market potential for cereals will be especially great in the near future. Brazil could become an important exporter of both corn and rice, although this also will depend partly on obtaining increases in productivity, the development of storage facilities, improved port facilities, and the development and use of grades and standards.

More important than any of these factors, however, will be the forelgn trade policy which Brazil follows. In the past, the combination of the greatly overvalued currency and embargoes on exports has re- 
sulted in internal prices for some agricultural products that are approximately half the world price. The effect of this is to reduce producer supply, stimulate domestic consumption, and forgo a rather large export potential.

The effect of these policies can be seen in the case of corn, a product of which Brazil has been a marginal exporter. It has been estimated that if the exchange rate had been set near its equilibrium level, and export reatrictions eliminated, corn exports would have increased an average of 693,000 tons per year in the period 1947-1966, for an average value of approximately $\$ 43 \mathrm{million}$ per year in exchange earnings.8 This is a large percentage increase, since the average exports in this period were 130,000 tons, with net imports occurring in three years. Similar gains could be obtained with other products.

In addition to the export potential of the cereals, other opportunities exist for specialized products in which Brazil has a comparative advantage. These include sisal, citrus fruits, and pineapple.

On the import side, Brazil can easily become self-sufficlent in food staples, and in the past has been more dependent on food imports than it really needed to be. The principal food import in the past has been wheat, and the magnitude of these imports has in the past been the result of irrational economic policies. Higher prices--as a result of the termination of 1 ts import subsidy--and the abundance of other domestic cereals has led to a marked reduction in the consumption of wheat. Future import needs will depend on the success of research programs to improve domestic varietieg and the rise in per capita incomes. In the meantime it has been shown that other cereals can be substituted in part for wheat.

Other food itern imported are largely producta assoclated with higher income levels. These demands will rise in a somewhat greater proportion than the increase in population and per capita incomes, and unless restrictions on imports are imposed, they w111 probably plaoe increased demands on export earnings. 
AGRICULTURE'S ROLE IN TOTAL GROWTH OF THE ECONOMY

The contribution of agriculture to the total growth of the economy has been substantial, although not as great as it might have been. The major limitation has been the failure to raise productivity. Production has increased but, as will be shown later, largely through the expansion of area planted and not through rises in yields or other factor productivities. A crude measure of the level of productivity in the agricultural sector is provided by the fact that in 1960,51 percent of the labor force was engaged in agricultural activities but generated only 26.5 percent of the net internal product.

In the present section an attempt is made to evaluate the major contributions that the agricultural sector has made to the development of the total economy. In some cases the supporting data are provided in other parts of the study.

\section{Expanding Non-Farm Labor Force}

The provision of a labor force for the non-farm sector has been little short of amazing, if measured in quantitative terms. The migration of agricultural laborers in the postwar period has been substantial. (See Chapter 2.)

On the other hand, the quality of this labor force has been less than desired. Investment in rural people in the form of education has been $1 \mathrm{im}-$ ited, and consequently the rural migrant arrives in the urban labor markets ill-equipped for alternative employment. This failure to invest in the schooling and training of rural people is a serious problem, and has reduced the contribution that the agricultural sector could be making to the total growth of the economy.

\section{Capital for Industrialization}

Although not generally recognized, the agricultural sector has provided a substantial amount of the conventional or tangible capital that has been used in the industrialization of Brazil. The role that agriculture has played and is playing as a source of export earnings has already been documented. 
But the contribution of agriculture to capital formation in the non-farm sector has been even greater than this would suggest.

For a long period of time Brazil has used various systems of multiple exchange rates to channel earnings from the coffee sector to the industrial sector. During one period the coffee producer received a price lower than the price at which the coffee was sold on the world market. The earnings accruing to the government were auctioned off to the industrial sector to finance capital formation, especially the importation of machinery and equipment. The magnitude of this transfer is unknown, but it was clearly substantial. Various other systems have been used, including the collection of an agio, a straight-out tax on each bag of coffee exported, and the direct manipulation of the exchange rates.

In addition to this transfer of capital through the foreign exchange market, much capital has flowed directly from the agricultural sector to the industrial sector. No data are available on this; but it is well known, for example, that many large coffee producers in são Paulo invested their earnings in the industry of são paulo. More generally, the banking system itself has played a major role in assembling the savings from the agricultural sector and investing them in the non-farm sector. And the very substantial transfer of capital from the Northeast to the South, which Baer perceptively documents, 9 is essentially a transfer from agriculture to the non-farm sector.

Hence, the contribution of agriculture as a source of capital to the non-farm sector has indeed been great. In fact, a case could probably be made that it has been too great. A re-investment of some part of this capital in the agricultural sector in the form of improvements in the quality of its labor force, in the construction of an adequate physical infrastructure, and in the financing of research might well have made the development of the total economy proceed on a more self-sustaining basis, and perhaps at a higher rate over the longer pull. 
An Adequate Diet For The Total Population

On this point the performance of the agricultural sector has been somewhat mixed. It appears that agricultural production has been keeping up with the increases in population and the increases in demand from rising incomes. If one assumes that the aggregate income elasticity of demand for food products is around .6 in Brazil, the increase in production has about kept pace with the expansion of aggregate demand for agricultural products.

However, as will be shown below, this increase in output has been accomplished by the expansion of production into new areas, rather than by an increase in productivity. For this reason there has been little or no basis for either a rise or a fall in the relative price of agricultural products. Because of the abundant supply of land, the country faces essentially a perfectly elastic long-run supply curve for agricultural products.

The data in Table 38 bear this out in part. The general index of prices of agricultural products declined approximately 11 percent from 1953 to 1967. However, this is a result in large part of the decline in the price of coffee. If the index exclusive of coffee is considered, the relative price of agricultural products has tended to increase, if the period since 1960 is compared with the 1950 's. There is also considerable year-to-year fluctuation.

Essentially the same picture is obtained if the indexes of prices for food products are considered. When coffee is excluded, the relative price of food products is relatively higher in the $1960^{\circ} \mathrm{s}$ than it was in the $1950^{\prime} \mathrm{s}$, although not much different from 1948. However, it is important to recognize that the aggregate index masks an important shift within the agricultural sector. The prices of products of vegetable origin have trended downward, while the relative prices of animal products have trended upward. A more detailed analysis of relative price trends within the agricultural sector is presented in Chapter 4. Since animal products are relatively unimportant in the diet of the lower-income classes, it would appear that the agricultural sector is making a modest contribution to the economy in the form of lower relative food prices. 
TABLE 38

Relative Wholesale Prices of Agricultural Products, 1948-1967

$(1953=100)$

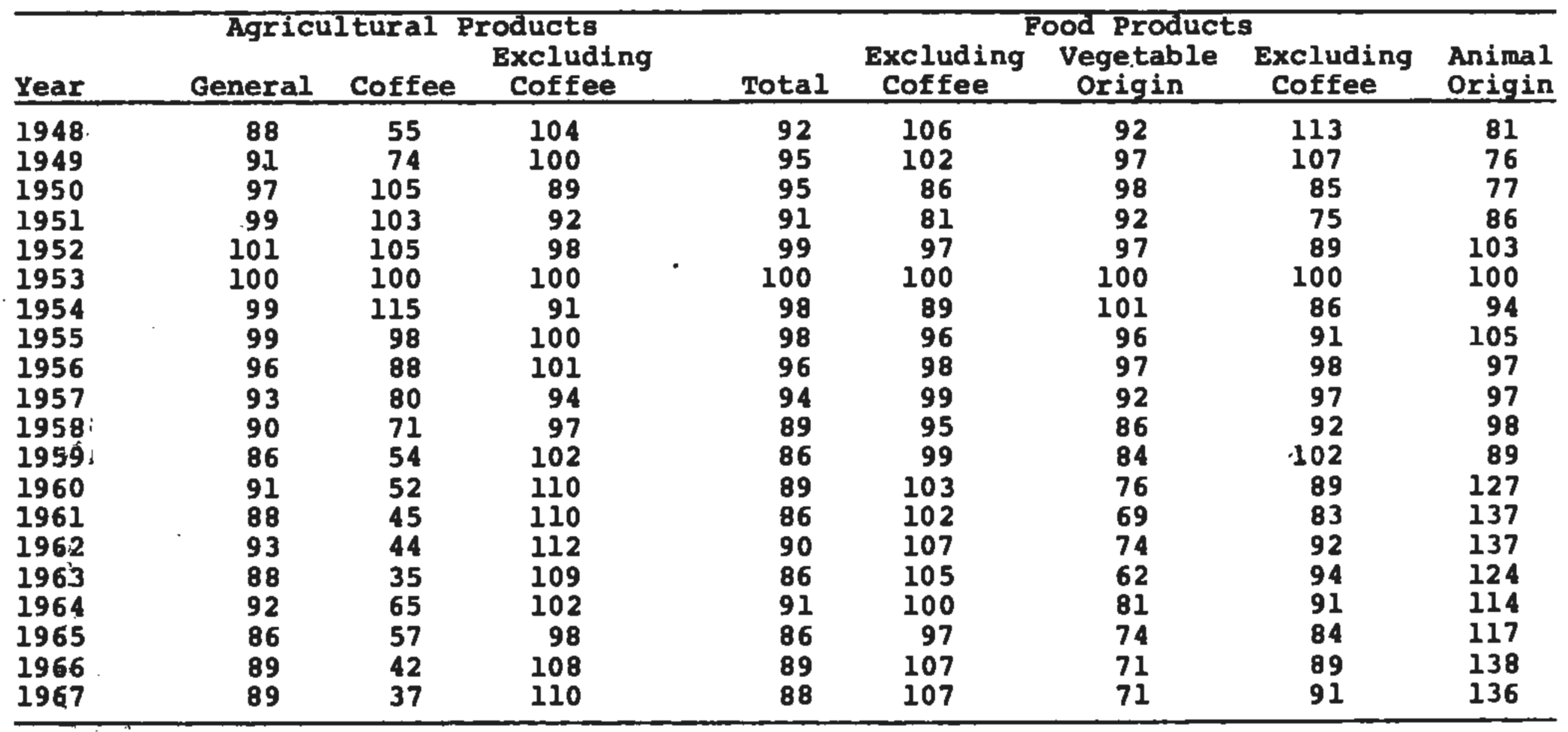

Source: The relative prices are calculated from Conjunctura EconAmica (Rio de Janetro: FGV, 1968), cols. 46, 47, 48, 56, 57, 58, 59, and 60. Each price index was deflated by col. 44, the general wholesale price index. 
since these prices are measured in the large urban centers, they suggest that the real price of food products at the farm level has declined somewhat. The food products tend to be shipped longer distances as new production areas open up. Hence, over time they bear a larger fraction of transportation costs.

In conclusion, it appears that in the entire postwar period the agricultural sector has made a modest contribution to total economic development by supplying food products at essentially a constant relative price. Relative food prices were somewhat lower during the $1950^{\circ} \mathrm{s}$, but rose to their immediate postwar levels in the $1960^{\prime} \mathrm{s}$. The source of this rise in the aggregate index was a rise in the relative price of products of animal origin. The agricultural sector has not, however, been the driving force that it might have been had relative agricultural prices declined substantially, with the attendant redistribution of income in favor of the poor and improved diets for low-income people.

\section{A Market For The Non-Farm Sector}

The agricultural sector has not, in general, provided an expanding market for the non-farm sector. Data presented in Chapter 2 suggest that per capita incomes in the farm sector are rising somewhat; and the purchase of goods from the non-farm sector has certainly increased over time, especially in the more productive, dynamic areas of the south.

However, the development policy which Brazil has followed, especially with respect to industrialization, has in many respects been an unfortunate one. The substitution of imports has resulted in an industrialization that has been oriented largely towards the upper-income groups. Production of goods for a mass market and the production of inputs for the agricultural sector have been largely ignored. As a result, the agricultural sector, which could have provided an expanding market were goods being produced for low-income groups or were inputs for the farm sector being produced, has not provided the stimulus which it might have to the total economy. The relative rise in the price of industrial products as a result of increasing levels of protection further complicated the problem. 
It is interesting to note that this phenomenon probably bears some responsibility for the problems encountered by the Brazilian economy in the 1960's. The emphasis on import substitution has resulted in an industrial sector oriented towards a small market, in large part the market of the upper-income groups. once this market was satisfied, then stagnation in the non-farm sector began to set in. This absence of markets appears to be one of the factors (only one) giving rise to the problems in the general economy in the mid-1960's.10

\section{A Source of Export Earnings}

Agriculture has been a major source of export earnings. The unfortunate thing is that its contribution could have been much greater. The restriction of coffee marketings in order to raise the price was, of course, a very rational short-run policy as long as the demand for Brazilian coffee was inelastic. However, the stimulus to production in other countries which this provided had a negative longer-run effect. In addition, the policy of restricting marketings should have been dropped once the market conditions had changed.

Equally important, however, was the impact of the overvalued currency and the negative approach to exports in general. The consequences of these policies were income forgone as opportunities to earn exchange earnings were lost and a stimulus of the industrial sector at the expense of the agricultural sector. Agricultural exports could have been much greater had the exchange rate been maintained closer to its equilbrium level, and had a more rational export policy been followed. II

\section{NOTES}

1. The material is taken from the CIDA Report, which in turn is based on a preliminary study for the Report by M. L. Rodrigues de Almeida, "A Task for Brazilian Agriculture: Some Aspects of the Gap Between Actual Consumption and That Based on an Adequate Diet in 1960 and 1970." (Mimeographed.) A more detailed analysis of the nutrition problem in the Northeast 
is given in Nutrition Survey--Northeast Brazil, a report by the U.S. Interdepartmental Committee on Nutrition for National Development.

2. According to FAO, VII Conferência Regional da FAO para América Latino, Documentos Básicos da Delegaçáo Brasileiro (1962), p. 18 (table IX), Brazil was fourth in Latin America in 1958, with 2,815 calories daily per capita. This estimate is based on the USDA World Food Budget.

3. CIDA Report, p. 31.

4. The estimates are based on Conselho do Desenvolvimento (1962); Conselho Coordenador do Abastecimento (1961); Comissão Nacional de Alimentação (1962). The calorie requirements are based on adjusted FAO recommendations and recommendations of Brazilian sources. For details see Rodrigues de Almeida, op. cit.

\section{See CIDA Report.}

6. For a more thorough discussion of these measures and their consequences to the general economy, see Nathaniel H. Leff, "Export Stagnation and Autarkic Development," Quarterly Journal of Economics, LXXXI (May, 1967), 286-301.

7. One of the problems in implementing this policy is that coffee has such a great comparative advantage over other production alternatives in the zones of specialized production. See Stahis Panagides, "Erradicação do Cafe e Diversificação da Agricultura Brasileira," Revista Brasileira de Econômica XXIII, No 1, 1969 .

3. Robert L. Thompson, "The Impact of Exchange Rate Policy and other Restrictive Policies on corn Exports in Brazil" (unpublished Master's thesis, Purdue University, 1969). Thompson also shows that the social costs of the policies followed are quite high, amounting in some years to 30 percent of the value of corn produced.

9. Werner Baer, Industrialization and Economic Development in Brazil (Homewood, III.: Richard D. Irwin, Inc., 1965. 
10. For detailed analyses of the difficulties of the 1960's, see Baer, op. cit.

11. See Thompson, OP. cit.; Euter Paniago, "An Evaluation of Agricultural Price Policies for Selected Food Products: Brazil" (unpublished Ph. D. thesis, Purdue University, 1969). 


\section{CHAPTER}

Brazil has ecological conditions for the production of a wide variety of agricultural products. 1 It is presently the world's largest producer of coffee and edible beans. It occupies fourth place in the production of corn, third in the production of tobacco and cocoa, and fourth in the production of cotton. It also has the third largest cattle herd in the world, and is the largest producer of rice in the Occident.

On the other hand, Brazil has a long record of losing its relative position in world markets. With one crop after another it has had a leading position, only to lose it when other countries improved their competitive position while Brazil stayed at the same level. This was the case in its early history with sugar, with rubber, and with cocoa; and it appears that the same thing is happening with coffee. Forty years ago Brazil produced 70 percent of the world production of coffee. Today it is producing only about 40 percent.

This is not to say, however, that the agricultural sector has been stagnant. On the contrary, agricultural output expanded at a rate of 4.7 percent a year between 1947 and 1962. After two bad crop years in 1963 and 1964 , it expanded at a rate of 5.6 percent in the period 1965-1967. Further indication of the changes that have been taking place is the expansion of cultivated area from 19 million hectares in 1950 to almost 30 million hectares in 1960. This represents an increase of almost 56 percent.

The objective of this chapter is to document in greater detail the changes taking place in the agricultural sector and to evaluate, to the extent possible, its general performance. The chapter is divided 
into six parts. The first part describes the structure of agricultural production and the trends in its major components. The second part deals with land use, landholdings, farm size, and other general aspects of the land resource. The third part presents details on the agricultural labor force which complements that provided in Chapter 2. Capital formation is analyzed in the fourth part, and the use of modern inputs in the fifth part. The chapter concludes with an analysis of yields, trends in yields, and a general analysis of factor productivity. Regional data will be provided to the extent possible.

\section{AGRICULTURAL PRODUCTION AND TRENDS}

Data on the twelve most important crops as of 1959 are presented in Table 39. They document in summary form some of the very large changes that have taken place in Brazilian agriculture in the postwar period.

In 1959 coffee was by far the most important crop, with a value of production equal to almost twice the value of the second and third place crops, rice and corn. By 1966, coffee had dropped to fourth place as measured by value of production, while rice and corn had moved up to first and second place, respectively. The bases for this shift in production were a decline in the area planted to coffee and a relatively large increase in the area planted to rice and corn.

Another large shift in ranking occurred for sugarcane, which moved up from sixth place to third. Other crops changed in ranking also, attesting to the flexibility of resource rise in the agricultural sector.

The importance of production for the export market can be seen from the table. of the twelve most important crops in 1959, four (coffee, cotton, sugarcane, and cocoa) were important export crops. Of the seven most important crops, three were important export products.

It is interesting to note that between 1959 and 1966 the relative importance of products consumed primarily in the internal market had increased. Rice and corn are largely consumed domestically, although 
TABLE 39

Production and Valie of Twelve Important Crops, 1959 and 1966

\begin{tabular}{|c|c|c|c|c|c|c|c|c|c|}
\hline Crop & $\begin{array}{c}\text { Unit } \\
\text { of } \\
\text { Meas- } \\
\text { ure } \\
\end{array}$ & $\begin{array}{c}\text { Quan- } \\
\text { tity } \\
\text { (thou- } \\
\text { sands) }\end{array}$ & $\begin{array}{l}\text { Area } \\
\text { Culti- } \\
\text { vated } \\
\text { (thous. } \\
\text { hec- } \\
\text { tares) } \\
\end{array}$ & $\begin{array}{c}959 \\
\text { Value } \\
\text { of } \\
\text { Produc- } \\
\text { tion } \\
\text { (thous. } \\
\text { NCr\$) } \\
\end{array}$ & Rank & $\begin{array}{c}\text { Quan- } \\
\text { tity } \\
\text { (thou- } \\
\text { sands) }\end{array}$ & $\begin{array}{l}\text { Area } \\
\text { Culti- } \\
\text { vated } \\
\text { (thous } \\
\text { hec- } \\
\text { tares) } \\
\end{array}$ & $\begin{array}{c}966 \\
\text { Value } \\
\text { of } \\
\text { Produc- } \\
\text { tion } \\
\text { (thous. } \\
\text { NCr\$) } \\
\end{array}$ & Rank \\
\hline Coffee & $\begin{array}{l}\text { metric } \\
\text { ton }\end{array}$ & 4,404 & 4,328 & 65.6 & 1 & 2,731 & 3,632 & 604.7 & 4 \\
\hline Rice & $\begin{array}{l}\text { metric } \\
\text { ton }\end{array}$ & 4,106 & 2,702 & 36.7 & 2 & 5,802 & 4,005 & 865.4 & 1 \\
\hline Corn & $\begin{array}{c}\text { metric } \\
\text { ton }\end{array}$ & 7,680 & 6,101 & 36.3 & 3 & 11,371 & 8,703 & 810.6 & 2 \\
\hline cotton & $\begin{array}{l}\text { metric } \\
\text { ton }\end{array}$ & 1,348 & 2,590 & 24.9 & 4 & 1,865 & 3,898 & 512.3 & 6 \\
\hline $\begin{array}{r}\text { Edıble } \\
\text { Beans }\end{array}$ & $\begin{array}{c}\text { metric } \\
\text { ton }\end{array}$ & 1,491 & 2,299 & 22.7 & 5 & 2,148 & 3,325 & 577.6 & 5 \\
\hline $\begin{array}{c}\text { Sugar- } \\
\text { cane }\end{array}$ & $\begin{array}{c}\text { metric } \\
\text { ton }\end{array}$ & 50,814 & 1,240 & 18.9 & 6 & 75,787 & 1,636 & 656.9 & 3 \\
\hline Mandioca & $\begin{array}{c}\text { metric } \\
\text { ton }\end{array}$ & 16,100 & 1,220 & 16.8 & 7 & 24,710 & 1,780 & 473.0 & 7 \\
\hline
\end{tabular}




\begin{tabular}{|c|c|c|c|c|c|c|c|c|c|}
\hline \multirow[b]{2}{*}{ Crop } & \multirow[b]{2}{*}{$\begin{array}{l}\text { Unit } \\
\text { of } \\
\text { Meas- } \\
\text { ure } \\
\end{array}$} & \multicolumn{4}{|c|}{1959} & \multicolumn{4}{|c|}{1966} \\
\hline & & $\begin{array}{c}\text { Quan- } \\
\text { tity } \\
\text { (thou- } \\
\text { sands } \\
\end{array}$ & $\begin{array}{c}\text { Area } \\
\text { Culti- } \\
\text { vated } \\
\text { (thous. } \\
\text { hec- } \\
\text { tares) } \\
\end{array}$ & $\begin{array}{l}\text { Value } \\
\text { of } \\
\text { Produc- } \\
\text { tion } \\
\text { (thous. } \\
\text { NCr\$) } \\
\end{array}$ & Rank & $\begin{array}{c}\text { Quan- } \\
\text { tity } \\
\text { (thou- } \\
\text { sands) }\end{array}$ & $\begin{array}{c}\text { Area } \\
\text { Culti- } \\
\text { vated } \\
\text { (thous. } \\
\text { hec- } \\
\text { tares) } \\
\end{array}$ & $\begin{array}{c}\text { Value } \\
\text { of } \\
\text { Produc- } \\
\text { tion } \\
\text { (thous. } \\
\text { NCr } \$ \text { ) } \\
\end{array}$ & Rank \\
\hline Wheat & $\begin{array}{l}\text { metric } \\
\text { ton }\end{array}$ & 792 & 1,256 & 9.4 & 8 & 615 & 717 & 156.1 & 10 \\
\hline Bananas & $\begin{array}{l}1,000 \\
\text { stalks }\end{array}$ & 240 & 169 & 6.9 & 9 & 356 & 245 & 228.6 & 8 \\
\hline Cocoa & $\begin{array}{l}\text { metric } \\
\text { ton }\end{array}$ & 170 & 461 & 6.4 & 10 & 170 & 456 & 97.7 & 12 \\
\hline $\begin{array}{l}\text { Irish } \\
\text { Potatoes }\end{array}$ & $\begin{array}{l}\text { metric } \\
\text { ton }\end{array}$ & 934 & 173 & 6.2 & 11 & 1,329 & 199 & 222.4 & 9 \\
\hline Oranges & $\begin{array}{l}1,000 \\
\text { fruits }\end{array}$ & 7,912 & 103 & 5.0 & 12 & 11,767 & 165 & 122.4 & 11 \\
\hline
\end{tabular}


both have considerable export potential. The quantity produced of both increased substantially over the period covered, as did other food items. The increase in production of rice, corn, and beans has been very strongly associated with the colonization of southern Goiás and Mato Grosso. The case of rice is especially striking, since in the postwar period there has been a doubling of per capita consumption.2

Similar data on the relative importance of various livestock groups are presented in Tables 40 and 41. Cattle is by far the most important livestock group, followed by swine. Poultry is the other important category of food-producing livestock.

Data on livestock numbers, and their evolution over time, are presented in Table 41 . Livestock numbers increased slowly from 1920 to 1940 . They grew at a more rapid rate from 1940 to 1950 , and from 1950 to 1960 they increased very rapidly.3 The number of swine increased quite rapidly from 1960 to 1966, as did the number of poultry. Unfortunately, data on livestock numbers are among the more deficient of Brazilian data. Recent sample surveys made by the Ministry of Agriculture suggest that at least cattle numbers are seriously overestimated in the official 1966 estimates reported in Table 41 .

Dairy cattle typically are not separated from beef cattle in the Brazilian data, since a large portion of the milk comes from non-specialized cattle. Estimates of the volume of milk produced from 1950 to 1966 are presented in Table 42 .

Production has been increasing steadily over time, and almost tripled between 1950 and 1966 , yet the consumption of fluid milk is quite low in Brazil. In 1960 the average consumption was estimated at 50 grams per capita, with higher consumption in the cities than in the rural areas. This compares with 1178 grams in Norway and 493 grams in the United States.

The production of milk is concentrated in two geographic regions. (This regional distribution has probably not changed greatly since 1958.) More specifically, it is concentrated in the states of Minas Gerais, são Paulo, and Rio de Janeiro, and supplies the cities of são Paulo, Río de Janeiro, and Belo Horizonte. The heavy concentrations of people in the Northeast consume very little milk. 
TABLE 40

Value of Livestock Herds, 1958 and 1966 (million NCr\$)

\begin{tabular}{lrr}
\hline Herds & 1958 & \multicolumn{1}{c}{1966} \\
\hline Cattle & 232 & 12,711 \\
Swine & 60 & 2,716 \\
Horses & 20 & 669 \\
Mules & 15 & 529 \\
Poultry & 10 & 487 \\
Sheep & 7 & 349 \\
Goats & 2 & 166 \\
Asses & 2 & 86 \\
\hline
\end{tabular}

Source: Plano Diretor (Rio de Janeiro: ABCAR, 1960): Anuario Estatistico do Brasil 1967 (Rio de Janeiro: IBGE, 1968).

TABLE 41

Principal Livestock Herds, 1920-1966 (millions)

\begin{tabular}{lrrrccr}
\hline Herd & 1920 & 1940 & 1950 & 1960 & 1962 & 1966 \\
\hline Cattle & 34.27 & 41.54 & 47.08 & 73.96 & 79.08 & 90.15 \\
Horses & 5.25 & 4.68 & 5.25 & & & \\
Asses, & & & & 14.53 & 15.51 & 9.08 \\
Mules & 1.86 & 2.13 & 2.50 & & & 7.63 \\
Swine & 16.16 & 16.84 & 23.03 & 47.94 & 52.94 & 61.73 \\
Goats & 5.08 & 6.25 & 6.96 & 11.20 & 12.40 & 13.96 \\
Sheep & 7.93 & 9.28 & 13.07 & 18.16 & 19.72 & 22.10 \\
Poultry & 52.94 & 62.91 & 77.83 & 184.13 & 207.74 & 268.02 \\
\hline
\end{tabular}

Source: Plano Diretor (Rio de Janeiro: ABCAR, 1960); Anuário Estatistico do Brasil 1967 (Rio de Janeiro: IBGE, 1968). 
Production of Milk, 1950-1966

(billion liters)

\begin{tabular}{llll}
\hline 1950 & 2.42 & 1959 & -- \\
1951 & 2.48 & 1960 & 4.90 \\
1952 & 2.98 & 1961 & 5.07 \\
1953 & 3.38 & 1962 & 5.30 \\
1954 & 3.62 & 1963 & 5.38 \\
1955 & 3.86 & 1964 & 6.15 \\
1956 & 4.11 & 1965 & 6.57 \\
1957 & 4.27 & 1966 & 6.70 \\
1958 & 4.46 & & \\
\hline
\end{tabular}

Source: Plano Diretor (Rio de Janeiro: ABCAR, 1960); Anuário Estatístico do Brasil 1967 (Rio de Janeiro: IBGE, 1968).

TABLE 43

Milk Production, by Region, 1958

\begin{tabular}{lcc}
\hline \multicolumn{1}{c}{ Region } & $\begin{array}{c}\text { Production } \\
\text { (thousand liters) }\end{array}$ & Percent \\
\hline North & 10,893 & 0.2 \\
Northeast & 252,666 & 5.7 \\
East & $2,004,456$ & 44.9 \\
South & $1,900,316$ & 42.6 \\
Central West & 269,041 & 6.6 \\
\hline
\end{tabular}

1960) Source: Plano Diretor (Rio de Janeiro: ABCAR, 
Only 25 percent of the milk produced is consumed in fluid form. The remaining 75 percent is consumed in manufactured form, of which the three principal forms are butter, cheese, and powdered milk. The data in Table 44 indicate that production of butter has declined, while the production of powdered milk has increased very substantially. Butter has suffered from the competition of margarine, while the growth in consumption of powdered milk reflects the insufficiency of cooling equipment. The powdered form is safer as a consumption good.

The relative importance of the crop and livestock sectors is shown in Table 45. Approximately one-third of the agricultural revenue comes from livestock, while slightly less than two-thirds comes from cultivated crops. Revenue from extractive products is relatively small.

Information on the regional distribution of agricultural production is presented in Table 46 . The concentration of agricultural production in the south is clearly indicated, as is the difference in regional production patterns. Extractive products are relatively important in the North, where they are almost as important as cultivated crops and animal agriculture. The Northeast is heavily oriented towards cultivated crops, as is the South. Livestock production is relatively more important in the East and central West.

\section{Trends In Agricultural Production}

Indexes of the quantity produced of the principal agricultural products, exclusive of coffee, together with data and population indexes to facilitate comparisons, are given Table 47. (Alternative population indexes are provided in the table in order to facilitate comparison with other data series which have different base periods. Over the period considered, agricultural production in the aggregate, exclusive of coffee, has grown faster than total population. From 1947 to 1963 the production of these products grew 132 percent, with an average annual variation of 5.5 percent. From 1950 to 1960 the increase in output was 51 percent and the average variation was 4.4 percent. (If coffee were included in the index, the increase for the total period would be 105 percent, and the average variation in the period from 1950 to 1960 would be 4 percent.) 
Production and Value of Manufactured Milk Products, 1958 and 1966

\begin{tabular}{lcccc}
\hline & $\begin{array}{c}\text { Produc- } \\
\text { tion } \\
\text { (metric } \\
\text { tons) }\end{array}$ & $\begin{array}{c}\text { Value } \\
\text { (thou- } \\
\text { sand } \\
\text { NCr\$) }\end{array}$ & $\begin{array}{c}\text { Produc- } \\
\text { tion } \\
\text { (metric } \\
\text { tons) }\end{array}$ & $\begin{array}{c}\text { Value } \\
\text { (thou- } \\
\text { sand } \\
\text { NCr\$) }\end{array}$ \\
\hline $\begin{array}{l}\text { Butter } \\
\text { Cheese }\end{array}$ & 30,378 & 2,408 & 25,016 & 46,411 \\
$\begin{array}{l}\text { Powdered } \\
\text { Milk }\end{array}$ & 40,767 & 1,995 & 44,794 & 71,146 \\
\hline
\end{tabular}

Source: Plano Diretor (Rio de Janeiro: ABCAR, 1960); Anuario Estatistico do Brasil 1967 (Rio de Janeiro: IBGE, 1968).

\section{TABLE 45}

Agricultural Revenue, by Product Groups, 1962-1964

\begin{tabular}{lcc}
\hline \multicolumn{3}{c}{$\begin{array}{c}\text { Average } \\
\text { Agricultural } \\
\text { Revenue } \\
1962-1964\end{array}$} \\
\hline Cultivated crops & (thousand NCr\$) & Percentage \\
Animal Products & $1,885,512$ & 63.5 \\
Extractive Products & $1,030,260$ & 34.7 \\
Total & $\frac{47,184}{2,962,956}$ & $\frac{1.6}{100.0}$ \\
\hline
\end{tabular}

Source: John Ginzel, "Importance and Characteristics of the Agricultural Sector in Brazil," (Purdue University). (Mimeographed.) Underlying data taken from Anuário Estatístico do Brasil (Rio de Janeiro: IBGE; various issues). 
Regional Distribution of Agricultural Revenue and Product Groups, 1962-1964

\begin{tabular}{lcccc}
\hline & Percent & \multicolumn{3}{c}{ Percentage of } \\
of Agri- & $\begin{array}{c}\text { Culti- } \\
\text { Regional }\end{array}$ & Animal & Extrac- \\
Regiona & Revenue & vated & Agri- & tive \\
Crops & culture & Crops \\
\hline North & 1.6 & 33.3 & 34.4 & 32.3 \\
Middle North & 3.3 & 54.6 & 29.2 & 16.2 \\
Northeast & 13.1 & 76.0 & 20.8 & 1.1 \\
East & 26.1 & 53.4 & 46.3 & .3 \\
South & 47.3 & 69.1 & 30.9 & -- \\
Central West & 8.6 & 54.5 & 45.3 & .1 \\
\hline
\end{tabular}

The regions are defined as follows:

1. North--Rondónia, Acre, Amazona, Roraima, Amapa, and Pará.

2. Middle North--Piauf and Maranhão.

3. Northeast--Ceaŕ, Rio Grande do Norte, Paralba, Pernambuco, and Alagoas.

4. East--Sergipe, Bahia, Minas Gerais, Espírito Santo, Rio de Janeiro, and Guanabara.

5. South--São Paulo, Paraná, Santa Catarina, and Rio Grande do Sul.

6. Central West--Mato Grosso, Goiás, and Distrito Federal.

Source: John Ginzel, "Importance and Characteristics of the Agricultural Sector in Brazil," (Purdue University). (Mimeographed.) Underlying data taken from Anuário Estatistico do Brasil (Rio de Janeiro: IBGE; various issues). 
TABLE 47

Index of Quantity Produced of Principal Agricultural Products,a Exclusive of Coffee, and Indexes of Population, 1947-1963/1967

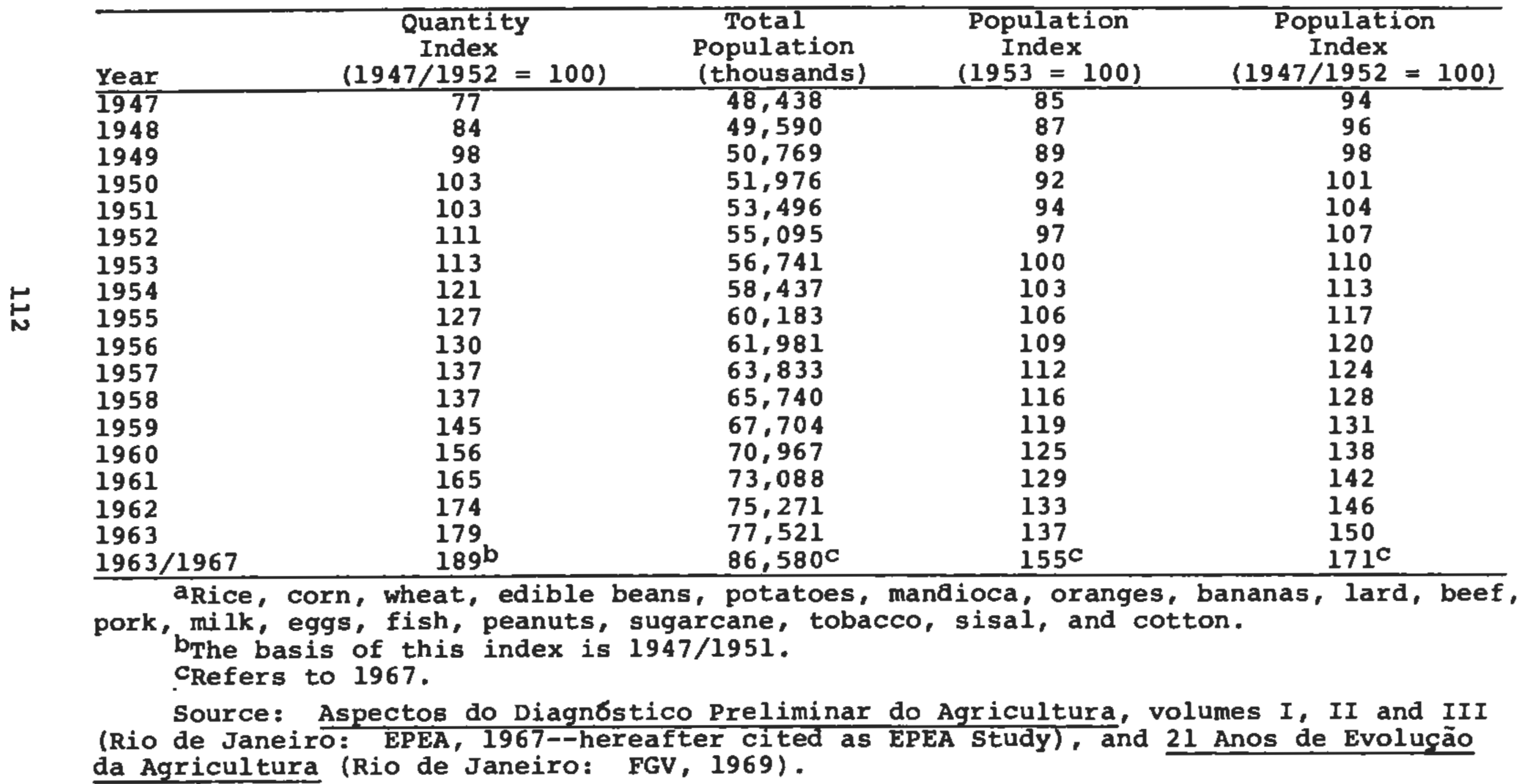


The demographic growth rate was approximately 3 percent during this period.

This does not indicate, however, that the supply of agricultural products grew more rapidly than the demand. If the relative price of food products in the aggregate did not change, the rate of increase in production is consistent with an income elasticity of demand of .6 for these products and a rise in per capita incomes of around 2 percent per year. Both of these are reasonable estimates, and suggest that total agricultural production did no more than keep up with the increases in demand. Approximately the same results apply to the 1963-1967 period, although per capita incomes probably did not grow as rapidiy in this period.

Data on the quantity of food products, broken down as to plant and animal origin are given in Table 48. These data indicate that production of animal origin expanded at approximately the same rate as production of plant origin over the entire period. This explains the shift in relative prices between these products that was shown in Table 38 . Products of animal origin tend to have a relatively higher income elasticity of demand, and production would need to have increased more rapidly than for products of plant origin if the relative prices were to have remained constant.

A breakdown on the production of food products of animal origin for the period 1950-1963 is given in Table 49. (More recent data on a disaggregated basis are not available.) Fish products had by far the largest percentage increase, 162 percent from 1953 to 1963 , but this is a relatively unimportant food item. Pork production increased by 67 percent in the same period, while beef production increased only 21 percent. The production of beef reached a peak in 1958-1959, tapered off in the following years, and held almost constant from 1960 to 1963. (These data are not necessarily inconsistent with the data on numbers above, since they refer to slaughter.) This was in the face of a 3 percent a year population growth and rising per capita incomes.

The breakdown of the production of food products of plant origin for the same period is given in Table 50. The following comments supplement the table and draw on data not presented therein. 
TABLE 48

Indexes of Quantity of Food Products, $1947 / 1951$ - 1963/1967

\begin{tabular}{llll}
\hline Year & $\begin{array}{l}\text { Plant } \\
\text { Origin }\end{array}$ & $\begin{array}{l}\text { Animal } \\
\text { Origin }\end{array}$ & Total \\
\hline $1947 / 1951$ & 100 & 100 & 100 \\
$1948 / 1952$ & 104 & 104 & 104 \\
$1949 / 1953$ & 107 & 109 & 108 \\
$1950 / 1954$ & 110 & 115 & 111 \\
$1951 / 1955$ & 114 & 121 & 116 \\
$1952 / 1956$ & 117 & 126 & 120 \\
$1953 / 1957$ & 123 & 134 & 126 \\
$1954 / 1958$ & 128 & 140 & 131 \\
$1955 / 1959$ & 136 & 147 & 139 \\
$1956 / 1960$ & 143 & 152 & 146 \\
$1957 / 1961$ & 155 & 156 & 155 \\
$1958 / 1962$ & 163 & 160 & 162 \\
$1959 / 1963$ & 171 & 162 & 168 \\
$1960 / 1964$ & 173 & 167 & 171 \\
$1961 / 1965$ & 183 & 174 & 180 \\
$1962 / 1966$ & 184 & 181 & 183 \\
$1963 / 1967$ & 189 & 187 & 189 \\
\hline
\end{tabular}

Source: 21 Anos de Evolugão da Agricultura (Rio de Janeiro: FGV, 1969). 
TABLE 49

Indexes of Quantity of Food Products of Animal Origin, 1950-1963

$(1953=100)$

\begin{tabular}{rcrr}
\hline Year & $\begin{array}{c}\text { Fish } \\
\text { Products }\end{array}$ & Pork & Beef \\
\hline 1950 & 95 & 91 & 97 \\
1951 & 19 & 102 & 102 \\
1952 & 109 & 97 & 99 \\
1953 & 100 & 100 & 100 \\
1954 & 107 & 106 & 102 \\
1955 & 118 & 110 & 101 \\
1956 & 130 & 117 & 109 \\
1957 & 135 & 128 & 117 \\
1958 & 134 & 132 & 131 \\
1959 & 158 & 124 & 128 \\
1960 & 175 & 125 & 122 \\
1961 & 205 & 144 & 121 \\
1962 & 258 & 169 & 120 \\
1963 & 262 & 167 & 121 \\
\hline
\end{tabular}

Source: EPEA Study. 
Indexes of Quantity of Food Products of Plant Origin, 1950-1963

$(1953=100)$

\begin{tabular}{lccccc}
\hline Year & Cereals $^{\mathbf{a}}$ & Legumes $^{\mathrm{b}}$ & $\begin{array}{l}\text { Tubers, } \\
\text { Roots }^{c}\end{array}$ & Fruits $^{\mathrm{d}}$ & Others $^{\text {e }}$ \\
\hline 1950 & 99 & 87 & 92 & 74 & 75 \\
1951 & 99 & 86 & 89 & 77 & 76 \\
1952 & 96 & 83 & 94 & 98 & 88 \\
1953 & 100 & 100 & 100 & 100 & 100 \\
1954 & 111 & 112 & 106 & 106 & 109 \\
1955 & 120 & 107 & 111 & 110 & 114 \\
1956 & 115 & 100 & 117 & 118 & 118 \\
1957 & 128 & 115 & 117 & 123 & 141 \\
1958 & 119 & 106 & 117 & 126 & 157 \\
1959 & 126 & 114 & 125 & 135 & 169 \\
1960 & 145 & 128 & 134 & 143 & 179 \\
1961 & 154 & 132 & 135 & 148 & 176 \\
1962 & 163 & 132 & 147 & 158 & 199 \\
1963 & 168 & 147 & 160 & 170 & 206 \\
\hline
\end{tabular}

acereals: rice, corn, wheat, oats, rye, barley.

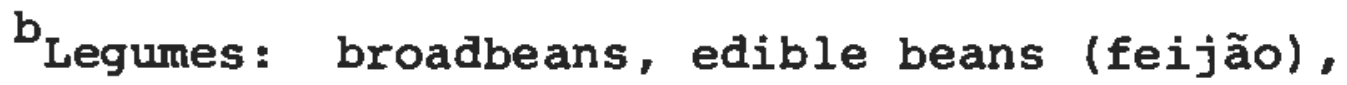
soybeans.

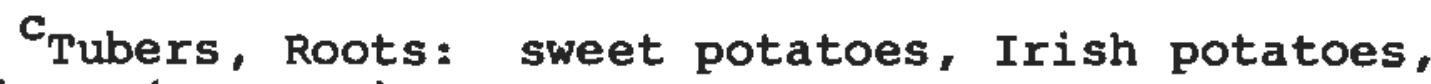
mandioca (cassava).

fruits: oranges, bananas, pineapples, avocados, coconuts, mangoes, peaches, tangerines, watermelons, lemons.

ethers: garlic, onions, tomatoes, European chestnuts, nuts, black pepper. 
Cereals

Rice, corn, and wheat are the principal products in this group and represent practically 99 percent of the quantity and value of production. The contribution, in volume, of corn in the group of cereals ranges from a minimum of 58 percent (1955) to a maximum of 63 percent (1963), varying between 60 and 62 percent in the other years.

In the same period, rice ranged from a minimum of 30 percent of the cereals produced (1954) to a maximum of 36 percent (1961). It is difficult to evaluate the role of wheat because of deficiencies in the data. However, estimates suggest a relative decline from 8 percent in 1953 to 2 percent in 1963.

With respect to the value of production, rice was in a position superior to corn in all of the period, with a minimum of 42 percent in 1955 and a maximum of 59 percent in 1963. In the remaining years it varied between 43 and 49 percent. In value terms, corn made up 35 percent of the total in 1963, 46 percent in 1959 and 1961 , and varied between 39 percent and 44 percent in the other years. The relative importance of corn among the cereals has tended to increase.

\section{Lequmeg}

Edible beans (feijão) are the most important product. in this category, both in quantity and in value. They make up more than 80 percent of the total in all of the years from 1953 to 1963. In value terms, edible beans varied from 39 percent to 95 percent of the total.

Soybeans have made up an increasingly larger part of the total, increasing from a low of 6 percent to a high of 14 percent in 1963 . In value terms they increased from 3 percent to 8 percent. The production of soybeans has increased rapidly since 1963 .

Roots, Tubers

Mandioca was responsible for 88-89 percent of the quantity of roots and tubers produced in the period from 1953 to 1963 . Sweet and Irish potatoes each contributed 5 to 6 percent of the volume. 
In value terms, mandioca participated with a minimum of 60 percent in 1955 and a maximum of 73 percent in 1962. Irish potatoes varied between a minimum of 20 percent and a maximum of 30 percent, and sweet potatoes varied between 7 and 10 percent.

Fruits

The two principal products in this group are bananas and oranges. The participation of bananas in the total production and value varied from 48 to 50 percent and from 37 to 45 percent, respectively. Oranges were in second place with 24-25 percent of the quantity and 19-27 percent of the value.

Others

The important products of plant origin are garlic, onions, and tomatoes.

of the five categories of food products of plant origin, cereals, legumes, and fruits expanded in about the same proportion. (See Table 50.) The specialty products, included in the "other" category, expanded more rapidly than the others; and legumes, an important source of plant protein, expanded less rapidly.

Price indexes for these several categories are presented in Table 51. Important changes in relative prices took place over the period considered. From 1953 to 1963 , the price of cereals increased least, with prices of tubers and roots and "others" increasing only slightly more. The prices of legumes increased substantially in relation to the others, as did the prices of fruits.

This suggests that even though the production of fruits expanded well in relation to the other products, it did not increase sufficiently to keep up with the increasing demand arising from the high income elasticity of demand for this product. On the other hand, the slower rate of expansion in the production of legumes has resulted in a higher relative price for this category. The rise in the relative price of this important protein source, as a result of the failure of production to expand, has important implications, especially in view of the simultaneous rise in the relative price of animal products. 
Price Indexes for Food Products of Plant Origin, 1950-1963

$(1953=100)$

\begin{tabular}{|c|c|c|c|c|c|}
\hline Year & Cereals & Legumes $^{b}$ & $\begin{array}{l}\text { Tubers, } \\
\text { Roots }\end{array}$ & Others $^{d}$ & Fruits ${ }^{e}$ \\
\hline 1950 & 47 & 43 & 62 & 56 & 52 \\
\hline 1951 & 48 & 54 & 72 & 55 & 60 \\
\hline 1952 & 66 & 75 & 79 & 75 & 86 \\
\hline 1953 & 100 & 100 & 100 & 100 & 100 \\
\hline 1954 & 106 & 79 & 107 & 125 & 127 \\
\hline 1955 & 125 & 140 & 117 & 125 & 151 \\
\hline 1956 & 150 & 215 & 143 & 131 & 188 \\
\hline 1957 & 165 & 212 & 176 & 171 & 217 \\
\hline 1958 & 192 & 200 & 207 & 249 & 265 \\
\hline 1959 & 254 & 385 & 267 & 311 & 346 \\
\hline 1960 & 298 & 559 & 320 & 323 & 422 \\
\hline 1961 & 378 & 529 & 460 & 595 & 584 \\
\hline 1962 & 787 & 1335 & 902 & 770 & 933 \\
\hline 1963 & 1180 & 1722 & 1219 & 1235 & 1556 \\
\hline
\end{tabular}

acereals: rice, corn, wheat, oats, rye, barley. soybeans.

begumes: broadbeans, edible beans (feijão).

C Tubers, Roots: sweet potatoes, Irish potatoes, mandioca (cassava).

dothers: garlic, onions, tomatoes, European chestnuts, nuts, black pepper.

eFruits: oranges, bananas, pineapples, avocados, coconuts, mangoes, peaches, tangerines, watermelons, lemons.

Source: EPEA Study. 
Brazilian agriculture has an important sector that produces primarily for further Industrialization. Data on the production trends of these producta are given in Table 52. Two producte stand out in terms of their relative increase in production. Peanuts, a relatively important product, expanded 312 percent in the perlod considered, whllo alat, of relatively loas importance, expanded 200 percent. The production of all componenta expanded rather well, however, with the poeatble exception of cautor beane, which rank with the legumed in their lag behind the other groupe.

The aggregate growth in the production of industrlable products between 1953 and 1963 was 80 peroent. This rapld growth colncides with a rather rapld expansion in the processing industry.

Detalled data on the princlpal agricultural exports are presented in Table 53. The predominant role of coftee $1 \mathrm{~s}$ eadily noted. Cotton tends to be gecond in Importance, ranking above cocoaj but the latter, and coffee, are produced principally for the export market.

A number of important polnts are to be noted from the table. The firat is the decilne of agricultural exports since the early 1950's. Thia reflects in large part a loss in the competitive position of both coffee and cocoa, but there 1 s not one product for which there lo a raplaly expanding export market. Th1s is in sharp contrast with the general Increase in world trade of agricultural producte during this pertod.

The second point 1 . the extent to which variationg in the exports of the various products have tended to be off-setting. Although the variation in the total remaine fairly large, it 18 nowhere near as large as the varlations in the Individual products.

\section{The Role of Coffee}

Additional detalis on the role that coffee plays In the Brazilian economy can be found in Table 54. In the postwar perlod it has produced as much as $B$ percent of national income, and as muoh as 74 percent of the exchange earnings. As a source of national 
TABLE 52

Indexes of Quantity of Principal Industriable Products, 1953-1963

$(1953=100)$

\begin{tabular}{ccccccccc}
\hline Year & Peanuts & $\begin{array}{c}\text { Castor } \\
\text { Beans }\end{array}$ & $\begin{array}{c}\text { Sugar- } \\
\text { cane }\end{array}$ & Cotton & Sisal & Tobacco & Grapes & Total \\
\hline 1953 & 100 & 100 & 100 & 100 & 100 & 100 & 100 & 100 \\
1954 & 115 & 106 & 105 & 105 & 99 & 111 & 107 & 106 \\
1955 & 127 & 102 & 107 & 115 & 135 & 112 & 105 & 109 \\
$\mathbf{N}$ & 123 & 100 & 115 & 108 & 153 & 109 & 126 & 112 \\
1956 & 131 & 125 & 124 & 106 & 154 & 106 & 140 & 116 \\
1957 & 210 & 108 & 130 & 103 & 158 & 109 & 141 & 120 \\
1958 & 244 & 112 & 140 & 126 & 213 & 115 & 144 & 136 \\
1959 & 279 & 140 & 148 & 145 & 247 & 122 & 151 & 150 \\
1960 & 399 & 129 & 155 & 165 & 257 & 127 & 159 & 166 \\
1961 & 442 & 140 & 163 & 171 & 262 & 142 & 141 & 173 \\
1962 & 412 & 149 & 166 & 176 & 300 & 157 & 179 & 180 \\
1963 & & & & & & & &
\end{tabular}

Source: EPRA Study. 
Brazilian agriculture has an important sector that produces primarily for further industrialization. Data on the production trends of these products are given in Table 52. Two products stand out in terms of their relative increase in production. Peanuts, a relatively important product, expanded 312 percent in the period considered, while sisal, of relatively less importance, expanded 200 percent. The production of all components expanded rather well, however, with the possible exception of castor beans, which rank with the legumes in their lag behind the other groups.

The aggregate growth in the production of industriable products between 1953 and 1963 was 80 percent. This rapid growth coincides with a rather rapid expansion in the processing industry.

Detailed data on the principal agricultural exports are presented in Table 53. The predominant role of coffee is easily noted. Cotton tends to be second in importance, ranking above cocoa; but the latter, and coffee, are produced principally for the export market.

A number of important points are to be noted from the table. The first is the decline of agricultural exports since the early $1950^{\prime} \mathrm{s}$. This reflects in large part a loss in the competitive position of both coffee and cocoa, but there is not one product for which there is a rapidly expanding export market. This is in sharp contrast with the general increase in world trade of agricultural products during this period.

The second point is the extent to which variations in the exports of the various products have tended to be off-setting. Although the variation in the total remains fairly large, it is nowhere near as large as the variations in the individual products.

\section{The Role of Coffee}

Additional details on the role that coffee plays in the Brazilian economy can be found in Table 54 . In the postwar period it has produced as much as 8 percent of national income, and as much as 74 percent of the exchange earnings. As a source of national 
TABLE 52

Indexes of Quantity of Principal Industriable Products, 1953-1963 $(1953=100)$

\begin{tabular}{ccccccccc}
\hline Year & Peanuts & $\begin{array}{l}\text { Castor } \\
\text { Beans }\end{array}$ & $\begin{array}{c}\text { Sugar- } \\
\text { cane }\end{array}$ & Cotton & Sisal & Tobacco & Grapes & Total \\
\hline 1953 & 100 & 100 & 100 & 100 & 100 & 100 & 100 & 100 \\
1954 & 115 & 106 & 105 & 105 & 99 & 111 & 107 & 106 \\
1955 & 127 & 102 & 107 & 115 & 135 & 112 & 105 & 109 \\
$\mathbf{N}$ & 123 & 100 & 115 & 108 & 153 & 109 & 126 & 112 \\
1956 & 131 & 125 & 124 & 106 & 154 & 106 & 140 & 116 \\
1957 & 210 & 108 & 130 & 103 & 158 & 109 & 141 & 120 \\
1958 & 244 & 112 & 140 & 126 & 213 & 115 & 144 & 136 \\
1959 & 279 & 140 & 148 & 145 & 247 & 122 & .151 & 150 \\
1960 & 399 & 129 & 155 & 165 & 257 & 127 & 159 & 166 \\
1961 & 442 & 140 & 163 & 171 & 262 & 142 & 141 & 173 \\
1962 & 412 & 149 & 166 & 176 & 300 & 157 & 179 & 180 \\
1963 & & & & & & & &
\end{tabular}

Source: EPEA Study. 
TABLE 53

Value of Exporta of Principal Agricultural Producte, 1949/1967

(m1lition U.S.\$)

\begin{tabular}{|c|c|c|c|c|c|c|c|c|c|c|}
\hline Year & $\begin{array}{l}\text { Total } \\
\text { (1) }\end{array}$ & $\begin{array}{l}\text { Coffee } \\
(2)\end{array}$ & $\begin{array}{c}\text { Cocoa, } \\
\text { Derivativesa } \\
\text { (3) }\end{array}$ & $\begin{array}{l}\text { Unginned } \\
\text { Cotton } \\
\text { (4) }\end{array}$ & $\begin{array}{c}\text { Tobacco } \\
\text { (5) }\end{array}$ & $\begin{array}{c}\text { S1gal } \\
(6)\end{array}$ & $\begin{array}{r}\text { Cane } \\
\text { Sugar } \\
(7)\end{array}$ & $\begin{array}{c}\text { Pine } \\
(8)\end{array}$ & $\begin{array}{l}\text { Others } \\
\text { (9) }\end{array}$ & $\begin{array}{l}\text { Total of } \\
\text { Cols } \\
\text { (2) to (8) }\end{array}$ \\
\hline $\begin{array}{l}1949 \\
1950 \\
1951 \\
1952 \\
1953 \\
1954 \\
1955 \\
1956 \\
1957 \\
1958 \\
1959 \\
1960 \\
1961 \\
1962 \\
1963 \\
1964 \\
1965 \\
1966 \\
1967\end{array}$ & $\begin{array}{l}1,096 \\
1,355 \\
1,769 \\
1,418 \\
1,540 \\
1,562 \\
1,423 \\
1,482 \\
1,392 \\
1,243 \\
1,282 \\
1,269 \\
1,403 \\
1,214 \\
1,407 \\
1,430 \\
1,595 \\
1,741 \\
1,654\end{array}$ & $\begin{array}{r}632 \\
866 \\
1,058 \\
1,045 \\
1,088 \\
948 \\
844 \\
1,030 \\
846 \\
688 \\
733 \\
713 \\
710 \\
643 \\
748 \\
760 \\
707 \\
764 \\
705\end{array}$ & $\begin{array}{r}58 \\
88 \\
78 \\
46 \\
87 \\
143 \\
100 \\
78 \\
89 \\
115 \\
85 \\
94 \\
61 \\
41 \\
51 \\
46 \\
41 \\
72 \\
82\end{array}$ & $\begin{array}{r}109 \\
105 \\
208 \\
35 \\
102 \\
223 \\
191 \\
86 \\
44 \\
25 \\
36 \\
46 \\
110 \\
112 \\
114 \\
108 \\
96 \\
111 \\
91\end{array}$ & $\begin{array}{l}15 \\
22 \\
19 \\
19 \\
17 \\
18 \\
19 \\
20 \\
18 \\
15 \\
16 \\
19 \\
27 \\
24 \\
24 \\
28 \\
26 \\
22 \\
20\end{array}$ & $\begin{array}{r}6 \\
13 \\
24 \\
14 \\
4 \\
9 \\
11 \\
15 \\
11 \\
11 \\
18 \\
21 \\
23 \\
23 \\
34 \\
38 \\
23 \\
22 \\
15\end{array}$ & $\begin{array}{r}4 \\
3 \\
4 \\
5 \\
22 \\
12 \\
47 \\
2 \\
46 \\
57 \\
43 \\
58 \\
66 \\
40 \\
72 \\
33 \\
57 \\
81 \\
80\end{array}$ & $\begin{array}{l}32 \\
33 \\
51 \\
32 \\
39 \\
38 \\
58 \\
34 \\
64 \\
52 \\
38 \\
43 \\
48 \\
39 \\
37 \\
46 \\
54 \\
56 \\
49\end{array}$ & $\begin{array}{l}240 \\
225 \\
328 \\
222 \\
181 \\
171 \\
213 \\
218 \\
274 \\
280 \\
314 \\
277 \\
359 \\
294 \\
326 \\
371 \\
252 \\
186 \\
253\end{array}$ & $\begin{array}{r}857 \\
1,130 \\
1,441 \\
1,196 \\
1,359 \\
1,392 \\
1,210 \\
1,264 \\
1,118 \\
963 \\
968 \\
992 \\
1,044 \\
921 \\
1,081 \\
1,059 \\
1,004 \\
1,128 \\
1,042\end{array}$ \\
\hline
\end{tabular}

acocoa in beans and butter.

brincipally pine slabs, simply prepared.

Source: Servico de Egtatfstica Econônica Financeira, Ministério da Fazenda; Anuário Estatistico do Brasil 1967 (Rio de Janeiro: IBGE, 1968); Relat6rio do Banco do Brasil I967. 
Role of coffee in Income Formation and Exchange Earnings,

1947-1964

\begin{tabular}{|c|c|c|c|c|}
\hline Year & $\begin{array}{l}\text { Income } \\
\text { Partici- } \\
\text { pation } \\
\text { (percent) }\end{array}$ & Index & $\begin{array}{l}\text { Exchange } \\
\text { Partici- } \\
\text { pation } \\
\text { (percent) }\end{array}$ & nings \\
\hline 1947 & 4 & 100 & 37 & 100 \\
\hline 1948 & 4 & 105 & 42 & 114 \\
\hline 1949 & 5 & 121 & 58 & 158 \\
\hline 1950 & 8 & 190 & 64 & 175 \\
\hline 1951 & 7 & 167 & 60 & 164 \\
\hline 1952 & 7 & 167 & 74 & 202 \\
\hline 1953 & 6 & 154 & 71 & 194 \\
\hline 1954 & 7 & 167 & 61 & 166 \\
\hline 1955 & 7 & 185 & 59 & 163 \\
\hline 1956 & 4 & 108 & 70 & 190 \\
\hline 1957 & 5 & 139 & 61 & 167 \\
\hline 1958 & 5 & 118 & 55 & 152 \\
\hline 1959 & 5 & 118 & 57 & 157 \\
\hline 1960 & 4 & 105 & 56 & 154 \\
\hline 1961 & 4 & 92 & 51 & 139 \\
\hline 1962 & 4 & 90 & 53 & 145 \\
\hline 1963 & 2 & 59 & 53 & 146 \\
\hline 1964 & 2 & 49 & 53 & 146 \\
\hline
\end{tabular}

Source: EPEA Study. 
income its role is declining, in large part because of the rapid expandion of the general economy during the 1950's. As a source of export earnings, its role has declined somewhat, although it still earns over 50 percent of the total. Both of these figures underestimate the full contribution of coffee to the total economy, since the coffee sector has played a major role in financing the industrialization that has taken place in Brazil. (See Chapter 3.) It is also an important source of employment.

The government policy of reducing the dependence on coffee could have a substantial impact on food production in the near future. Moreover, it could put Brazil in a more competitive position on the world market, since the newer plantings are of higheryield varieties. However, the surplus production is still considerable, and government stocks are quite large. Moreover, compliance with the World Coffee Agreement will reduce the degree of freedom of policy makers and will prevent Brazil from fully exploiting any comparative advantage she may have.

\section{LAND USE AND ORGANIZATION}

The total area of Brazil has been estimated at $851,000,000$ hectares by the National Council of Geography, and at $846,000,000$ hectares by the population census. According to the 1960 census, only 3.5 percent of the total area of the country was cultivated, and only some 30 percent of the total area of the country was counted as land in farms.

Table 55 provides perspective on the change in land in farms since 1940 on a regional basis. The North has the smallest fraction of its land in farms, while the South has the largest fraction. (A sizable fraction of the land not in farms is public land under state control.) Over the time period covered, all areas have had an increase in the fraction of the land in farms. This increase has not been uniform among the regions, however. In the decade of the $1940^{\prime} \mathrm{s}$, both the Northeast and the Central west had relatively large increases in the area in farms, while the North actually had a slight decrease. In the decade of the $1950^{\prime} \mathrm{s}$, the increases were more uniform, with the exception of the North, which had a larger increase in absolute terms. Since this 
TABLE 55

Area in Farms, by Region, 1940-1960

\begin{tabular}{|c|c|c|c|c|c|c|c|}
\hline Region & Hectares & $\begin{array}{l}940 \\
\text { Percent of } \\
\text { Total Area }\end{array}$ & $\begin{array}{l}\text { Area in } \\
\text { Hectares }\end{array}$ & $\begin{array}{l}\text { Farm Land } \\
950 \\
\text { Percent of } \\
\text { Total Area }\end{array}$ & Hectares & $\begin{array}{l}960 \\
\text { Percent of } \\
\text { Total Area }\end{array}$ & $\begin{array}{l}\text { Total } \\
\text { Area } \\
1960\end{array}$ \\
\hline North & 25.5 & 7 & 23.1 & 7 & 32.0 & 9 & 355 \\
\hline Northeast & 28.6 & 30 & 41.5 & 43 & 46.0 & 48 & 96 \\
\hline East & 53.2 & 42 & 59.6 & 47 & 65.6 & 51 & 126 \\
\hline South & 50.0 & 62 & 54.4 & 67 & 60.1 & 74 & 81 \\
\hline $\begin{array}{c}\text { Central } \\
\text { West }\end{array}$ & 40.3 & 21 & 53.6 & 29 & 61.4 & 33 & 188 \\
\hline Brazil & 197.6 & 23 & 232.2 & 27 & 265.1 & 31 & 846 \\
\hline
\end{tabular}

$a_{\text {Area in million hectares. }}$

Source: Anuário Estatistico do Brasil (Rio de Janeiro: IBGE, various issues). 
increase is on a relatively small base, the percent of land in farms was still relatively small in 1960.

It is important to recognize that two of the regions which cover a large portion of the geographic area of Brazil have relatively small fractions of their total area in farm land. The North, which involves 42 percent of the total area in farm land. The North, which involves 42 percent of the total area of the country, had only 9 percent of its area in farms in 1960. The Central West, which covers 22 percent of the total area, had only 33 percent of its area in farms.

It is argued that both of these regions have extensive areas that are cultivable. Data on this are quite limited, however, and very little is known about what is necessary to make them productive. They are tropical and semi-tropical zones, with soils about which very little is known. Moreover, the infrastructure in the form of penetration roads, railroads, and other public services is inadequate to bring these areas into the general economy in the short run. It should be pointed out, however, that rapid settlement and development is taking place in both areas, especially where the distances to market are relatively short.

For example, there is much agricultural development along the Belém-Brasilia highway. The southern part of Mato Grosso is being occupied rapidly, much of it by farmers from São Paulo, many of whom bring a rather high level of technical know-how with them. Improved roads and/or railroads are a necessity for the region, however. The paving of the roads connecting Belo Horizonte, Rio de Janeiro, and são Paulo to Brasilia is stimulating both the agriculture and the general economy of Goiás. The state of Maranhão, the largest in area of the Northeast, apparently has good conditions for agriculture. This area is currently receiving a migration stream from the more populated states of the region. It appears to have great potential over the longer run.

of the $8,500,000 \mathrm{sq} . \mathrm{km}$. of land area in the country, it is estimated that more than 75 percent is forested. Moreover, a large portion of the country is hilly-to-mountainous. Large sections of the country consist of soils that are unsuited or poorly suited for agriculture with present techniques of production. 
Soil reconnaissance studies have been made so far on only about $600,000 \mathrm{sq}$. $\mathrm{km}$., but it is generally known that

Brazil, in spite of its enormous
surface, is relatively poor with
regard to soil resources. As. most
of its surface is located in the
tropics, soil fertility, mainly in
the Amazon area, is rapidly ex-
hausted after deforestation.
There are, however, considerable
areas available of reasonably
high natural soil fertility and
favorable topography which, when
adequately managed, constitute an
appreciable resource for both plant
and animal production. other ex-
tensive regions, where the main
limiting factor is low fertility,
can be used for agricultural pro-
duction through adequate ferti-
lizing. 3

Despite the low fertility level of most Brazilian soils, many of them have a great of potential. The basic soil structure tends to be good; and with the exception of the Northeast, the rainfall is adequate. The addition of the three principal plant nutrients, plus some of the minor elements, turns the leached-out soils into highly productive soils. The development of a strong fertilizer industry is quite important, however, as is research which identifies nutrient limitations and estimates yield response.

Viewed in a regional context, the soils of the southern part of Brazil, particularly those in são Paulo, Parana, and the Minas Triangle, are some of the most fertile in the world. The terrain is levelto-gently rolling, and rainfall is adequate for a wide variety of crops. Minas Gerais, an important agricultural state, is not so well endowed with good soils, and the terrain tends to be more hilly. The large Northeast, with its heavy concentrations of population, has semi-arid climatic conditions with periodic droughts that are quite serious. 


\section{Regional Distribution of Farms}

Data on the percentage distribution of land in farms by region, number of farms, and relative farm size are given in Table 56. The bulk of the land in farms is in the East, South, and Central West.

There were some important regional shifts within the twenty-year period of 1940-1960, however. Between 1940 and 1950 there was a relative shift from the North, East, and South in favor of the Northeast and Central West. Between 1950 and 1960, the shift was from the Northeast, East, and South in favor of the North. It should be emphasized that these are relative shifts, since with the exception of the North, land in farms for each region expanded throughout the period. (See Table 55.)

The distribution of the number of farms among the regions is quite different from the distribution of land in farms. Over 90 percent of the farms are in the Northeast, East, and South. The North and especially the Central West have a much smaller fraction of the number of farms than they have land in farms. The Northeast has a relatively larger fraction of the number of farms than it has land in farms.

These discrepancies are reflected in the relative size of the farms. The Central West has a relative farm size that is much greater than that in the rest of the country, reflecting the rather extensive farm organization of that region. At the other extreme, the Northeast has the smallest farm size, reflecting in part a much denser rural population. The IBRA survey made in 1965 indicates the following average farm sizes, by region: North, 429 hectares; Northeast, 81; East, 69; South, 50; Central West, 523; Brazil, 92.. These data suggest a shift in relative farm size between 1960 and 1965, although the comparability of the data is not known. 4

A number of the regions have experienced substantial changes in relative farm size over the period covered. Area per farm in the East, for example, increased in relation to the national average between 1950 and 1960. Thisi appears to be the result of farm consolidation. Migration out of this region was relatively large in that decade, and there was a relative decline in the number of farm units. This was a relatively large resource adjustment. 


\section{TABLE 56}

Percentage Distribution of Land in Farms and Number of Farms, Region, and

Relative Farm Size, 1940-1960

\section{Central}

Year North Northeast East South West Total

\section{Land in Farms}

$\begin{array}{rrrrrrr}1940 & 12.90 & 14.47 & 26.89 & 25.36 & 20.39 & 100 \\ 1950 & 9.96 & 17.89 & 25.69 & 23.45 & 23.10 & 100 \\ 1960 & 12.18 & 17.33 & 24.71 & 22.63 & 23.09 & 100\end{array}$

Number of Farms

$\begin{array}{lllllll}1940 & 4.26 & 25.03 & 33.85 & 33.40 & 3.46 & 100 \\ 1950 & 3.77 & 26.31 & 32.04 & 34.02 & 3.86 & 100 \\ 1960 & 4.13 & 28.82 & 28.21 & 33.77 & 4.77 & 100\end{array}$

Area per Farm as

Percent of National Average

$\begin{array}{llllll}1940 & 303 & 58 & 79 & 76 & 589 \\ 1950 & 263 & 68 & 80 & 69 & 598 \\ 1960 & 295 & 60 & 87 & 67 & 485\end{array}$

Source: Anuário Estatístico do Brasil (Rio de Janeiro: IBGE, various issues). 
In the Central West, the adjustment was in the other direction. Area per farm declined in relation to the national average during the $1950^{\prime} \mathrm{s}$. This is a reflection of a relatively large in-migration, which is reflected in part in the increase in the relative share of the number of farms.

In the Northeast, which already had the smallest area per farm in relation to the national average, there was a further decline in a relative sense in the decade of the 1950's. Apparently, the relatively large out-migration from the Northeast was not sufficient to lead to substantial farm consolidation.

The remaining major shift occurred in the North. The reversal in relative farm size was apparently due in large part to the shift in land in farms.

\section{Land Use}

It has been pointed out that only 30 percent of the total area of Brazil was counted as land in farms in 1960. In the present section it will be shown that the land in farms is used rather extensively. The data are presented in Table 57.

As of 1960, approximately 40 percent of the land in farms was either forested, cultivable but not under cultivation, or not usable for agriculture. Another 41 percent of the land in farms was in natural pasture. This leaves about 20 percent as cultivated land, of which well over a third is in artificial pastures. Of the 11.5 percent of the land in farms which was in crops, over a third was in permanent crops.

Between 1950 and 1960 , however, there was a substantial intensification in land use. The percentage of land in crops increased from 8.2 to 11.5 , with a relative increase in both temporary and permanent crops. (Total land in farms increased substantially during this period also. See Table 55.) The relative share of land in artificial pasture also increased, so that total land cultivated increased from 14.6 percent of the total in 1950 to approximately 20 percent in 1960. The fraction of the land in. farms that was in natural pasture remained about 


\section{TABLE 57}

Percentage Distribution of Land in Farms by Major Land Use and by Region, 1950 and 1960

\begin{tabular}{|c|c|c|c|c|c|c|c|c|c|c|c|}
\hline Region & $\begin{array}{c}\text { Total Area } \\
\text { (million } \\
\text { hectares) }\end{array}$ & $\begin{array}{l}\text { Temp. } \\
\text { Crops }\end{array}$ & $\begin{array}{l}\text { Perm. } \\
\text { Crops }\end{array}$ & $\begin{array}{l}\text { Total } \\
\text { Crops }\end{array}$ & $\begin{array}{l}\text { Artif. } \\
\text { Past. }\end{array}$ & $\begin{array}{l}\text { Total } \\
\text { Cult. }\end{array}$ & $\begin{array}{l}\text { Nat. } \\
\text { Past. }\end{array}$ & Forest & $\begin{array}{l}\text { Usable } \\
\text { but } \\
\text { not } \\
\text { Used }\end{array}$ & Unprod. & Totala \\
\hline \multicolumn{12}{|l|}{1950} \\
\hline \multirow{3}{*}{$\begin{array}{l}\text { North } \\
\text { North- } \\
\text { east } \\
\text { East } \\
\text { South } \\
\text { Central } \\
\text { West } \\
\text { Brazil }\end{array}$} & 23.1 & .8 & .2 & 1.0 & .4 & 1.4 & 10.1 & 76.8 & 8.8 & 2.7 & 100.0 \\
\hline & $\begin{array}{l}41.5 \\
59.6 \\
54.4\end{array}$ & $\begin{array}{r}8.5 \\
6.5 \\
12.1\end{array}$ & $\begin{array}{l}.6 \\
3.1 \\
4.0\end{array}$ & $\begin{array}{r}9.1 \\
9.6 \\
16.1\end{array}$ & $\begin{array}{r}.9 \\
12.3 \\
8.0\end{array}$ & $\begin{array}{l}10.0 \\
21.9 \\
24.2\end{array}$ & $\begin{array}{l}27.9 \\
37.9 \\
42.2\end{array}$ & $\begin{array}{l}24.2 \\
17.1 \\
15.7\end{array}$ & $\begin{array}{l}27.9 \\
15.1 \\
13.5\end{array}$ & $\begin{array}{l}9.9 \\
8.1 \\
4.4\end{array}$ & $\begin{array}{l}100.0 \\
100.0 \\
100.0\end{array}$ \\
\hline & $\begin{array}{r}53.6 \\
232.0\end{array}$ & $\begin{array}{l}1.0 \\
6.3\end{array}$ & $\begin{array}{r}.1 \\
1.9\end{array}$ & $\begin{array}{l}1.1 \\
8.2\end{array}$ & $\begin{array}{l}5.2 \\
6.4\end{array}$ & $\begin{array}{r}6.3 \\
14.6\end{array}$ & $\begin{array}{l}61.9 \\
39.9\end{array}$ & $\begin{array}{l}17.7 \\
24.1\end{array}$ & $\begin{array}{r}8.0 \\
14.7\end{array}$ & $\begin{array}{l}6.1 \\
6.5\end{array}$ & $\begin{array}{l}100.0 \\
100.0\end{array}$ \\
\hline \multicolumn{12}{|l|}{1960} \\
\hline \multirow{3}{*}{$\begin{array}{l}\text { North } \\
\text { North- } \\
\text { east } \\
\text { East } \\
\text { South } \\
\text { Central } \\
\text { Heat } \\
\text { Brazil }\end{array}$} & 32.0 & 1.4 & .4 & 1.8 & .8 & 2.6 & 8.7 & 73.0 & 12.8 & 2.9 & 100.0 \\
\hline & $\begin{array}{l}46.0 \\
65.0 \\
60.0\end{array}$ & $\begin{array}{r}11.5 \\
7.9 \\
16.0\end{array}$ & $\begin{array}{l}3.1 \\
4.0 \\
6.2\end{array}$ & $\begin{array}{l}14.6 \\
11.8 \\
22.2\end{array}$ & $\begin{array}{r}1.7 \\
12.6 \\
10.6\end{array}$ & $\begin{array}{l}16.3 \\
24.5 \\
32.7\end{array}$ & $\begin{array}{l}31.7 \\
42.6 \\
37.6\end{array}$ & $\begin{array}{l}24.0 \\
15.6 \\
17.1\end{array}$ & $\begin{array}{r}20.4 \\
11.1 \\
9.0\end{array}$ & $\begin{array}{l}7.6 \\
6.2 \\
3.6\end{array}$ & $\begin{array}{l}100.0 \\
100.0 \\
100.0\end{array}$ \\
\hline & $\begin{array}{r}61.0 \\
264.0\end{array}$ & $\begin{array}{l}2.0 \\
8.4\end{array}$ & 3.1 & $\begin{array}{r}2.3 \\
11.5\end{array}$ & $\begin{array}{l}8.1 \\
8.0\end{array}$ & $\begin{array}{l}10.4 \\
19.5\end{array}$ & $\begin{array}{l}61.6 \\
40.9\end{array}$ & $\begin{array}{l}17.2 \\
23.2\end{array}$ & $\begin{array}{r}6.5 \\
11.3\end{array}$ & $\begin{array}{l}4.3 \\
5.1\end{array}$ & $\begin{array}{l}100.0 \\
100.0\end{array}$ \\
\hline
\end{tabular}

a Discrepancies due to rounding.

Source: Anuário Estatistico do Brasil (Rio de Janeiro: IBGE, selected issues). 
constant, but there were relative declines in the share of land in farms classified as forest, as usable but not used, and as unproductive.

Land use varies a great deal from one region to another. The south has by far the largest fraction of its land in crops or under cultivation. The Northeast was second in 1960 in percentage of land in crops, although the East was second in fraction of land under cultivation. This was a result of the East's having a much larger fraction of its farm land in artificial pastures.

Both the North and the Central West have relatively small fractions of the farm land in crops or under cultivation. These two regions differ substantially, however, in that the Central west had some 62 percent of its land in natural pastures in 1960, while in the North, 73 percent of the land in farms was in forest.

There were important shifts among the regions between 1950 and 1960. For example, relatively larger increases in the percent of land in crops took place in the Central west and the North--in that order--followed by the Northeast. Both the North and the Northeast had relatively large increases in the percent of farm land in artificial pasture, while the East had only a slight increase. The North had a decline in the percent of its land in natural pasture, while the central West held about steady. The other three regions had similar relative increases in the percent of farm land in natural pasture. In summary, the North, Northeast, and Central West had the relatively greater increase in intensification of land use between 1950 and 1960 , although both the North and the Central west were still quite extensively exploited in 1960.

An important aspect of land use in Brazil is the production of temporary crops in combination with other temporary or permanent crops. Examples are corn and beans, cotton and beans, or rice in combination with other crops. Such "crop associations" are in part a means for sharecroppers or small farmers to grow food products for their subsistence or for sale in connection with a product which the landlords raise for organized, commercial markets (cotton in the Northeast). The sharecroppers are permitted to grow subsistence food crops while the 
major commercial crop (coffee or cocoa) is being readied for production. More generally the use of crop associations is a way of effectively utilizing the effort spent on clearing the land and preparing the seedbed, and a means of spreading weather and price risks.

Tables 58 and 59 indicate the hectares of various temporary crops grown singly or in association in 1949 (the most recent year for which comprehensive data are available) and the number of farms on which these crops have been reported as grown singly or in association nationally by region. The proportion of hectares or farms where crops are grown together varied sharply by region. As a general rule the importance of "associated" cropping is positively related to the incidence of sharecropping as a method of exploiting the land. The proportion of the important crops which are grown "in association" declines as one moves from the North and Northeast to the south. Since sharecropping has given way to other forms of employment in many areas of the country, it is probable that the 1960 census will show a decline in the importance of "associated" cropping. Since both sharecropping and associated cropping are important means of spreading risk, the fact that the incidence of both is less in the south may reflect less risk from weather in that region. In addition, interplanting is less compatible with the use of animal or mechanical power, which is also more highly concentrated in the South.

It is important to recognize that the existence of this associated cropping affects other data in important and unknown ways. Yields of individual crops grown in association may be lower than when grown individually, although the combined yield of the two may be greater than either one grown singly. It also affects the reporting of acreage and leads to certain inconsistencies in the data on land use.

\section{The New Lands}

The data in Table 55 indicate a sizable increase in total land in farms (32.0 million hectares) between 1950 and 1960. Census data indicate that land in permanent and temporary crops increased by 10.6 miliion hectares in this same period.

About one-half of the increase in total farm land occurred in the sparsely settled Central West region and in the territories of the North. On a 
TABLE 58

Temporary Crops: Total Hectarega and Percent Grown in Association With Other Temporary Crops, by Region, 1950 (thousand hectares)

\begin{tabular}{|c|c|c|c|c|c|c|c|c|c|c|c|c|}
\hline \multirow{2}{*}{ Crop } & \multicolumn{2}{|c|}{$\begin{array}{l}\text { Brazil } \\
\text { Percent }\end{array}$} & \multicolumn{2}{|c|}{$\begin{array}{l}\text { North } \\
\text { Percent }\end{array}$} & \multicolumn{2}{|c|}{$\begin{array}{l}\text { Northeast } \\
\text { Percent }\end{array}$} & \multicolumn{2}{|c|}{$\begin{array}{l}\text { East } \\
\text { Percent }\end{array}$} & \multicolumn{2}{|c|}{$\begin{array}{l}\text { South } \\
\text { Percent }\end{array}$} & \multicolumn{2}{|c|}{$\begin{array}{r}\text { Central West } \\
\text { Percent }\end{array}$} \\
\hline & Ha. & Assoc. & Ha. & AssOC. & Ha. & Assoc. & Ha. & Assoc. & Ha. & Assoc. & Ha. & Assoc. \\
\hline $\begin{array}{l}\text { Plneapple } \\
\text { Agave } \\
\text { Cassava } \\
\text { Cotton } \\
\text { Peanuts } \\
\text { Rice }\end{array}$ & $\begin{array}{r}10.3 \\
48.8 \\
286.5 \\
2,037.4 \\
90.1 \\
2,163.6\end{array}$ & $\begin{array}{r}34.0 \\
14.4 \\
13.3 \\
30.8 \\
9.4 \\
24.0\end{array}$ & $\begin{array}{r}.6 \\
-. \\
4.4 \\
5.1 \\
65.1\end{array}$ & $\begin{array}{c}22.1 \\
\overline{37.2} \\
87.8 \\
90.2\end{array}$ & $\begin{array}{r}5.8 \\
46.8 \\
9.6 \\
1,166.3 \\
1.7 \\
334.7\end{array}$ & $\begin{array}{l}56.5 \\
15.0 \\
32.7 \\
42.5 \\
18.6 \\
73.8\end{array}$ & $\begin{array}{r}1.8 \\
2.0 \\
29.2 \\
108.5 \\
10.0 \\
587.4\end{array}$ & $\begin{array}{r}2.8 \\
.5 \\
5.4 \\
55.7 \\
3.4 \\
9.2\end{array}$ & $\begin{array}{c}1.9 \\
b \\
232.9 \\
747.0 \\
77.3 \\
958.7\end{array}$ & $\begin{array}{r}2.4 \\
-. \\
13.4 \\
8.3 \\
10.1 \\
12.0\end{array}$ & $\begin{array}{r}.2 \\
10.3 \\
10.4 \\
.9 \\
217.6\end{array}$ & $\begin{array}{r}6.8 \\
-- \\
5.1 \\
40.4 \\
2.7 \\
23.9\end{array}$ \\
\hline $\begin{array}{l}\text { Sweet } \\
\text { Potatoes } \\
\text { Irish }\end{array}$ & 130.2 & 6.1 & .3 & 21.7 & 18.7 & 31.6 & 11.7 & 10.7 & 98.9 & .7 & .5 & 23.0 \\
\hline $\begin{array}{l}\text { Potatoes } \\
\text { Sugarcane } \\
\text { Onions }\end{array}$ & $\begin{array}{r}94.6 \\
853.2 \\
25.2\end{array}$ & $\begin{array}{r}6.8 \\
.8 \\
3.7\end{array}$ & $\overrightarrow{7.2}$ & 10.9 & $\begin{array}{r}4.0 \\
305.3 \\
.9\end{array}$ & $\begin{array}{r}57.4 \\
.7 \\
11.7\end{array}$ & $\begin{array}{r}6.3 \\
320.4 \\
2.4\end{array}$ & $\begin{array}{r}11.3 \\
1.3 \\
14.2\end{array}$ & $\begin{array}{r}84.0 \\
207.3 \\
21.8\end{array}$ & $\begin{array}{r}4.1 \\
.2 \\
2.2\end{array}$ & $\begin{array}{c}.2 \\
b\end{array}$ & $\begin{array}{r}.5 \\
1.6 \\
2.7\end{array}$ \\
\hline $\begin{array}{l}\text { Rye } \\
\text { Barley }\end{array}$ & $\begin{array}{l}20.8 \\
21.6\end{array}$ & $b^{2}$ & $=$ & $\begin{array}{l}-- \\
--\end{array}$ & $=$ & - & b & $=$ & $\begin{array}{l}20.7 \\
21.6\end{array}$ & $\dot{b}^{2}$ & $=$ & $=$ \\
\hline $\begin{array}{l}\text { Lima Beans } \\
\text { Beans } \\
\text { Castor }\end{array}$ & $\begin{array}{r}44.1 \\
2,363.7\end{array}$ & $\begin{array}{l}97.5 \\
72.5\end{array}$ & 21.0 & $\begin{array}{l}60.0 \\
83.7\end{array}$ & $\begin{array}{r}34.4 \\
789.9\end{array}$ & $\begin{array}{l}98.9 \\
91.7\end{array}$ & $\begin{array}{r}9.0 \\
880.1\end{array}$ & $\begin{array}{l}93.1 \\
70.3\end{array}$ & 587.5 & $\begin{array}{r}2.5 \\
49.5\end{array}$ & $\begin{array}{r}.5 \\
85.0\end{array}$ & $\begin{array}{l}95.4 \\
72.9\end{array}$ \\
\hline $\begin{array}{l}\text { Beans } \\
\text { Yucca } \\
\text { Corn } \\
\text { Tomatoes } \\
\text { Wheat } \\
\text { Tobacco }\end{array}$ & $\begin{array}{r}99.1 \\
728.7 \\
5.311 .8 \\
9.7 \\
515.7 \\
95.7\end{array}$ & $\begin{array}{r}50.7 \\
28.2 \\
42.9 \\
16.1 \\
.2 \\
13.7\end{array}$ & $\begin{array}{c}.1 \\
75.4 \\
68.4 \\
b \\
-- \\
6.4\end{array}$ & $\begin{array}{c}95.2 \\
54.0 \\
88.5 \\
50.0 \\
=- \\
25.7\end{array}$ & $\begin{array}{r}48.0 \\
266.4 \\
991.4 \\
3.6 \\
b \\
8.9\end{array}$ & $\begin{array}{l}64.7 \\
47.5 \\
91.7 \\
26.4 \\
21.6 \\
26.7\end{array}$ & $\begin{array}{r}30.9 \\
258.7 \\
1,576.0 \\
1.7 \\
2.9 \\
52.3\end{array}$ & $\begin{array}{r}28.0 \\
7.9 \\
45.6 \\
15.7 \\
16.2\end{array}$ & $\begin{array}{r}19.8 \\
114.0 \\
2,508.0 \\
4.1 \\
512.4 \\
26.5\end{array}$ & $\begin{array}{r}52.2 \\
8.6 \\
20.3 \\
6.6 \\
.2 \\
.6\end{array}$ & $\begin{array}{r}.2 \\
13.9 \\
167.8 \\
b \\
.2 \\
1.4\end{array}$ & $\begin{array}{r}15.7 \\
58.6 \\
47.9 \\
9.4 \\
1.5 \\
33.2\end{array}$ \\
\hline
\end{tabular}

a Not including land in these crops grown in association with permanent crops. bInsignificant.

Source: Censo Agrícola de 1950. 
TABLE 59

Farms Growing Crops Singly or in Association, Farms Reporting Crop Grown by Resident Personnel, 1950

\begin{tabular}{|c|c|c|c|c|c|}
\hline Crop & $\begin{array}{l}\text { No. Farms } \\
\text { Reporting } \\
\text { the Crop } \\
\text { (thousands) }\end{array}$ & Pe: & $\begin{array}{l}\text { nt of Farms Repo } \\
\text { In Association } \\
\text { with Another } \\
\text { Temporary Crop }\end{array}$ & $\begin{array}{l}\text { rting Crops } \\
\text { In Association } \\
\text { with a } \\
\text { Permanent Crop }\end{array}$ & $\begin{array}{c}\text { No. of Farms Reporting } \\
\text { Crop Grown by Resident } \\
\text { Personnela } \\
\text { (thousands) }\end{array}$ \\
\hline $\begin{array}{l}\text { Pineapple } \\
\text { Agave } \\
\text { Cassava } \\
\text { Cotton } \\
\text { Peanutg } \\
\text { Rice } \\
\text { Sweet Potatoes } \\
\text { Irish Potatoes } \\
\text { Sugarcane } \\
\text { Onions } \\
\text { Rye } \\
\text { Barley } \\
\text { Lima Beans } \\
\text { Beans } \\
\text { Tobacco } \\
\text { Castor Beans } \\
\text { Yucca } \\
\text { Corn } \\
\text { Tomatoes } \\
\text { Wheat }\end{array}$ & $\begin{array}{r}6.7 \\
6.5 \\
288.1 \\
351.4 \\
94.0 \\
683.4 \\
247.8 \\
129.4 \\
213.1 \\
66.6 \\
25.4 \\
17.6 \\
27.2 \\
1,176.2 \\
105.5 \\
52.7 \\
510.1 \\
1,554.0 \\
6.0 \\
228.6\end{array}$ & $\begin{array}{l}67.6 \\
73.1 \\
91.8 \\
60.9 \\
95.3 \\
72.5 \\
95.9 \\
98.0 \\
97.7 \\
98.5 \\
99.9 \\
99.9 \\
4.3 \\
42.7 \\
95.7 \\
61.7 \\
77.9 \\
48.4 \\
90.2 \\
99.6\end{array}$ & $\begin{array}{r}23.1 \\
25.3 \\
7.2 \\
38.5 \\
2.8 \\
24.1 \\
3.6 \\
1.7 \\
1.2 \\
1.3 \\
.1 \\
6 \\
94.7 \\
52.3 \\
4.1 \\
37.3 \\
21.3 \\
47.1 \\
8.2 \\
.3\end{array}$ & $\begin{array}{r}9.3 \\
1.6 \\
1.0 \\
.6 \\
1.9 \\
3.4 \\
.5 \\
.3 \\
1.1 \\
.2 \\
b \\
b \\
1.0 \\
5.0 \\
.2 \\
1.0 \\
.8 \\
4.5 \\
1.6 \\
.1\end{array}$ & $\begin{array}{r}.2 \\
.22 \\
-.6 \\
2.7 \\
-. \\
28.5 \\
7.0 \\
-- \\
.8 \\
.3 \\
.3 \\
5.0 \\
141.7 \\
-.- \\
5.7 \\
53.7 \\
152.5 \\
.3 \\
4.7\end{array}$ \\
\hline
\end{tabular}

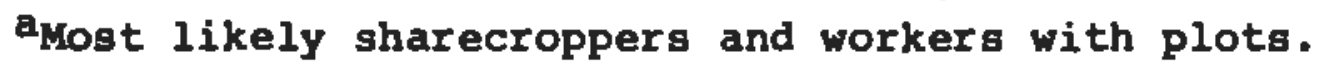

bInsignificant

Source: Censo Agrfcola da 1950. 
percentage basis, the expansion of land in farms was rather uniform anong regions, except for the very small increase in the North and the relatively large increase in the territories.

The expansion of crop land, however, varied a great deal among regions. A significant share (28 percent) of the added crop land is accounted for by. the Northeast, which has 17 percent of the total land in farms. The expansion is equally important in the south ( 23 percent of total farm land), which accounted for 42 percent of the new crop land. In the two regions, 67 percent and 79 percent, respectively, of this addition in total farm land is accounted for by new crop land.

Both the North and the Central West had relatively large percentage increases in crop land. However, in both cases these were relatively small in absolute terms, and on a very small base.

If, as in 1950, about 6.4 percent of the total new farm land ( $i . e$. , about $17 \mathrm{million}$ hectares) was set aside for artificial pasture, there remained in 1960 an estimated 219 million hectares, most of which is in natural pasture and forest. (This analysis is taken from the CIDA Report.) Much of this land is employed for livestock. The 1960 census reported 55.7 million head of cattle--46.9 million were reported in 1950--an increase of about 8.8 million head in 10 years. (The discrepancy between the census estimate and the SEP data reported in Table 41 should be noted. The SEP data (Servico de Estatistica da Producão, Ministry of Agriculture) are estimated at the municipio (county) level and are not obtained by sampling procedures. It is not clear, however, which of these data series is in error.) The bulk of these animals were in the East and South, but the sharpest increase took place in the sparsely settled Central West.

If one assumes as a rough approximation that, as in 1950, each head of cattle occupied 2.3 hectares in artificial and natural pasture, then the increased number of animals would need an additional 20.2 million hectares of pasture, which is just about the difference between the increase in total farm land and new land in crops (22.6 million hectares). Thus, about two-thirds of the expanded agricultural "plant" in this decade was devoted to 
TABLE 60

Changes in Land in Farms and in Crops, by Region, 1950-1960 (million hectares)

\begin{tabular}{|c|c|c|c|c|c|c|c|c|}
\hline Region & $\begin{array}{c}\text { Potal } \\
\text { in Far } \\
1950\end{array}$ & Total $\stackrel{(1)}{\text { Hectares }}$ & \multicolumn{2}{|c|}{$\begin{array}{c}\text { (2) } \\
\text { Total Hectares } \\
\text { in Crops }\end{array}$} & \multicolumn{2}{|c|}{$\begin{array}{c}\text { (3) } \\
\text { Percent } \\
(2) \text { of (1) } \\
1950 \quad 1960\end{array}$} & $\begin{array}{c}\text { (4) } \\
\text { Percent } \\
\text { Since } \\
\text { Total Land }\end{array}$ & $\begin{array}{c}\text { (5) } \\
\text { Increase } \\
1950 \\
\text { Crop Land }\end{array}$ \\
\hline $\begin{array}{l}\text { North } \\
\text { Northeast } \\
\text { East } \\
\text { South } \\
\text { Central West } \\
\text { All states }\end{array}$ & $\begin{array}{r}12.2 \\
41.5 \\
59.6 \\
54.4 \\
53.6 \\
221.3\end{array}$ & $\begin{array}{r}12.3 \\
46.0 \\
65.6 \\
60.1 \\
61.4 \\
245.4\end{array}$ & $\begin{array}{r}.2 \\
3.8 \\
5.7 \\
8.8 \\
.6 \\
19.1\end{array}$ & $\begin{array}{r}6.4 \\
7.8 \\
13.3 \\
1.4 \\
29.7\end{array}$ & $\begin{array}{r}2 \\
9 \\
10 \\
16 \\
1 \\
9\end{array}$ & $\begin{array}{r}3 \\
15 \\
12 \\
22 \\
2 \\
12\end{array}$ & $\begin{array}{l}1 \\
11 \\
10 \\
10 \\
15 \\
11\end{array}$ & $\begin{array}{r}94 \\
82 \\
37 \\
51 \\
133 \\
56\end{array}$ \\
\hline $\begin{array}{l}\text { Territories } \\
\text { Brazil }\end{array}$ & $\begin{array}{r}10.9 \\
232.2\end{array}$ & $\begin{array}{r}20.0 \\
265.1\end{array}$ & $\begin{array}{c}c \\
19.1\end{array}$ & $\begin{array}{c}c \\
29.7\end{array}$ & 8 & 11 & $\begin{array}{l}83 \\
14\end{array}$ & $\begin{array}{r}109 \\
56\end{array}$ \\
\hline
\end{tabular}

Note: Discrepancies due to rounding.

axcluding the territories Acre, Rio Branco, Amapa, Rond6nia, which are included under "Territories."

bAnnual and permanent crops only.

dabout 20,000 (1950) and 41,000 (1960).

Insignificant.

Source: Censo Agrícola Preliminar, 1960. 
TABLE 61

Distribution of Cattle $e^{a}$ by Region, 1950 and 1960

(millions)

\begin{tabular}{lrr}
\hline Region & 1950 & 1960 \\
\hline North & 1.0 & 1.2 \\
Northeast & 5.6 & 6.4 \\
East & 16.4 & 18.9 \\
South & 16.9 & 18.7 \\
Central West & 7.0 & 10.5 \\
Brazil & 46.9 & 55.7 \\
\hline
\end{tabular}

${ }^{a}$ Including draft animals.

Source: Censo Agrícola da 1950, Censo Agrícola Preliminar, 1960. 
livestock. The relative importance of livestock in Brazilian agriculture, especially from the standpoint of land use, is evident from the fact that in 1950,19 percent of the farm land was in "crop farms" (i.e., farms primarily devoted to crops), 36 percent in livestock farms, and another 36 percent in combined livestock and crop farms, where the livestock usually occupies most of the area. The production of livestock in Brazil is a very extensive operation, however, especially when compared with such important crops as coffee and sugarcane. Hence, although livestock is an important "land user," its relative importance as a source of revenue is considerably less. (See Table 45.)

\section{Size Distribution of Land Holdings}

The size distribution of land ownership in Brazil is highly skewed, although it is not clear that it is more highly skewed than in countries with a more modern agriculture. Data on the distribution of land holdings are given in Table 62 .

In $1960,44.8$ percent of the farm units were less than 10 hectares in size and accounted for 2.2 percent of all the land in farms. Conversely, 0.1 percent of the farms were larger than 10,000 hectares in size and accounted for 19.9 percent of the land in farms. In broad terms, close to 90 percent of the holdings were less than 100 hectares in size, but occupied only 20.2 percent of the land, while 1.6 percent of the farms were larger than 1,000 hectares in size and accounted for 47.3 percent of the farm land.

Between the censuses of 1950 and 1960 the proportions shifted somewhat. The percent of farm units of less than 10 hectares increased substantially during the decade, while the percent of larger units declined. In terms of total area, the percent of total land in the classes of under 10 and 10-100 hectares increased from 1950 to 1960 , while the percent of land in the 1,000-10,000-hectare class declined.

Data on the distribution of land holdings by regions is given in Table 63. There are very important differences among the regions. In the Northeast, for example, 66 percent of the farm units 
TABLE 62

Number and Area of Establishments, by Total Area, 1950 and 1960

\begin{tabular}{|c|c|c|c|c|c|c|c|c|}
\hline \multirow{3}{*}{$\begin{array}{c}\text { Size of } \\
\text { Farm } \\
\text { (hectares) }\end{array}$} & \multicolumn{4}{|c|}{ Establishments } & \multicolumn{4}{|c|}{ Total Area } \\
\hline & \multirow{2}{*}{\multicolumn{2}{|c|}{$\begin{array}{l}\text { Number } \\
\text { (thousands) } \\
1950 \quad 1960\end{array}$}} & \multicolumn{2}{|c|}{ Percent } & \multicolumn{2}{|c|}{$\begin{array}{c}\text { Hectares } \\
\text { (thousands) }\end{array}$} & \multicolumn{2}{|c|}{ Percent } \\
\hline & & & 1950 & 1960 & 1950 & 1960 & 1950 & 1960 \\
\hline Under 10 & 711 & 1,500 & 34.4 & 44.8 & 3,025 & 5,923 & 1.3 & 2.2 \\
\hline $10-100$ & 1,053 & 1,495 & 60.0 & 44.6 & 35,563 & 47,698 & 15.3 & 18.0 \\
\hline $100-1,000$ & 268 & 315 & 13.0 & 9.4 & 75,521 & 86,292 & 32.5 & 32.5 \\
\hline $1,000-10,000$ & 31 & 31 & 1.5 & .9 & 73,093 & 72,795 & 31.5 & 27.4 \\
\hline Over 10,000 & 1.6 & 1.7 & .1 & .1 & 45,009 & 52,743 & 19.4 & 19.9 \\
\hline Unclassified & .3 & 7.3 & -- & .2 & -- & -- & -- & -- \\
\hline Total & 2,065 & 3,349 & 100.0 & 100.0 & 232,211 & 265,451 & 100.0 & 100.0 \\
\hline
\end{tabular}

Source: Censo Agrícola da 1950; Censo Agrícola Preliminar, 1960. 
TABLB 63

Number and Areg of Establiohmente, by Regton, 1950 and 1960

\begin{tabular}{|c|c|c|c|c|c|c|c|c|c|c|c|c|c|c|c|c|c|c|c|c|}
\hline \multirow[b]{3}{*}{$\begin{array}{l}\text { Eatablich- } \\
\text { mente } \\
\text { (hectares) }\end{array}$} & \multicolumn{4}{|c|}{ North } & \multicolumn{4}{|c|}{ Northeast } & \multicolumn{4}{|c|}{ Eagt } & \multicolumn{4}{|c|}{ South } & \multicolumn{4}{|c|}{ Central west } \\
\hline & \multicolumn{2}{|c|}{1950} & \multicolumn{2}{|c|}{1960} & \multicolumn{2}{|c|}{1950} & \multicolumn{2}{|c|}{1960} & \multicolumn{2}{|c|}{1950} & \multicolumn{2}{|c|}{1960} & \multicolumn{2}{|c|}{1950} & \multicolumn{2}{|c|}{1960} & \multicolumn{2}{|c|}{1950} & \multicolumn{2}{|c|}{1960} \\
\hline & $\begin{array}{l}\text { No. } \\
\text { Bat. }\end{array}$ & Area & $\begin{array}{l}\text { No. } \\
\text { Bet. }\end{array}$ & Area & no. & area & no. & area & No. & Area & no. & Area & Mo. & Arod & No. & Area & 10. & area & no. & Area \\
\hline Under 10 & 38.3 & 0.5 & 51.9 & 0.8 & 56.8 & 2.6 & 66.0 & 4.0 & 32.5 & 1.6 & 39.0 & 2.5 & 21.1 & 1.5 & 34.4 & 3.4 & 11.3 & 0.1 & 18.6 & 0.2 \\
\hline $10-100$ & 49.3 & 5.2 & 40.8 & 4.9 & 31.1 & 14.0 & 25.4 & 17.7 & 51.4 & 20.6 & 40.5 & 24.4 & 67.5 & 27.4 & 50.0 & 31.6 & 39.0 & 2.6 & 46.7 & 4.8 \\
\hline $100-1,000$ & 9.2 & 9.6 & 5.8 & 6.8 & 11.0 & 41.0 & 7.4 & 42.5 & 15.0 & 43.1 & 11.8 & 43.9 & 10.3 & 35.5 & 7.0 & 34.3 & 38.3 & 21.1 & 28.0 & 24.7 \\
\hline $\begin{array}{l}1,000- \\
10,000\end{array}$ & 2.6 & 23.6 & 1.1 & 14.1 & 1.1 & 31.7 & 0.6 & 27.0 & 1.1 & 26.5 & 0.7 & 22.5 & 1.1 & 29.9 & 0.6 & 25.0 & 10.5 & 41.9 & 6.2 & 12.2 \\
\hline $\begin{array}{l}\text { Over } \\
10,000\end{array}$ & 0.4 & 60.9 & 0.3 & 73.4 & 0 & 10.7 & 0 & 0.0 & 0 & 6.2 & 0 & 6.7 & 0 & 5.8 & 0 & 5.7 & 0.9 & 34.4 & 0.5 & 28.0 \\
\hline
\end{tabular}

Eource: Censo Agrícola da 1950, Censo Agrícola Prellminar, 1960. 
were smaller than 10 hectares in 1960 . In the North also, the majority of farm units were less than 10 hectares. In the other three regions the most common class of farm was the 10-100-hectare size, with the percentage varying from 46.7 percent in the Central West to 58 percent in the South.

It should also be noted that the large--over10,000-hectare units--occur principally in the very sparsely settled regions of the North and Central West. Forty-five percent of the area of farms in this size group is located in the North, with a very heavy concentration in the territory of Acre, which has 69.5 percent of the land in this size group in the North, and 31.2 percent in relation to all of Brazil. The exceedingly heavy concentration of large farms in these two regions can be further seen by noting that in the North, 1.4 percent of the farms were over 1,000 hectares, but included 87.5 percent of the total area; in the Central West, 6.7 percent were over 1,000 hectares and included 70.2 percent of the total area; and that in each of the other three regions, less than 1 percent of the farms were of this size group and included between 29.2 percent and 35.8 percent of the total area $(1960$ data). Hence, the North and Central West carry a heavy weight in national averages on the distribution of size holdings--and they are both very sparsely settled, little-developed areas.

If one looks at the other end of the distribution, the Central West and North are again found to depart significantly from the other three regions. In the North, 92.7 percent of the farm units are 100 hectares or less, but they include only 5.7 percent of the land in farms (1960 data). In the Central West, 65.3 percent of the farms are 100 hectares or less, but include 5 percent of the land in farms. In the other three regions, the percent of farms 100 hectares or less ranges from 87.5 percent in the East to 92.4 percent in the South, including 26.9 percent and 35 .percent, respectively, of the land in farms. Hence, the Central West does not have the high concentration of very small farms that the other four regions have.

In considering the changes from 1950 to 1960 , it should be noted that the number of farms under 10 hectares increased in relative importance in all of 
the regions. All other categories decreased in each region except for the Central West, where the 10-100hectare size group also increased.

The mere consideration of land area is not a valid basis for comparison of farm size, however. Differences in fertility and climatic conditions operate to make a lo-hectare unit quite viable economically in one region, while a loo-hectare unit would not be viable in another region. The CIDA Report attempted to come to grips with this by classifying farms by the additional criterion of the number of people employed or employable. This approach assumes that there is a close relationship between physical conditions on the farms and the amount of labor which they can support:

The classifications (renamed here to avoid the emotion-laden concepts of minifúndio and latifúndio) which they developed were as follows: 5

1. Sub-familial farms--those of a size inadequate to give full, year-round employment, at present levels of technology and resources, to 2 people (Class I).

2. Family farms--those which give full employment to 2-4 people, with most of the farm work carried out by the members of the farm family (class II).

3. Multi-family, medium-sized farms--those large enough to give full employment to 4-12 people (Class III).

4. Multi-family, large farms--those which give full employment to over 12 people (Class IV).

"Full employment" is used here in the broad sense, to mean that the amount of full-time work would provide an income which would furnish the workers with adequate food, housing, and clothing and some savings.

Despite the crudeness by which such estimates are necessarily made, we reproduce them for the major regions in Table 64. The data indicate that for all Brazil, 38 percent of the farm units are family farms, and that in 1960 these included 8 percent of 
TABLE 64

Relative Importance of Classes of Farms, by Region, 1950 and $1960^{a}$

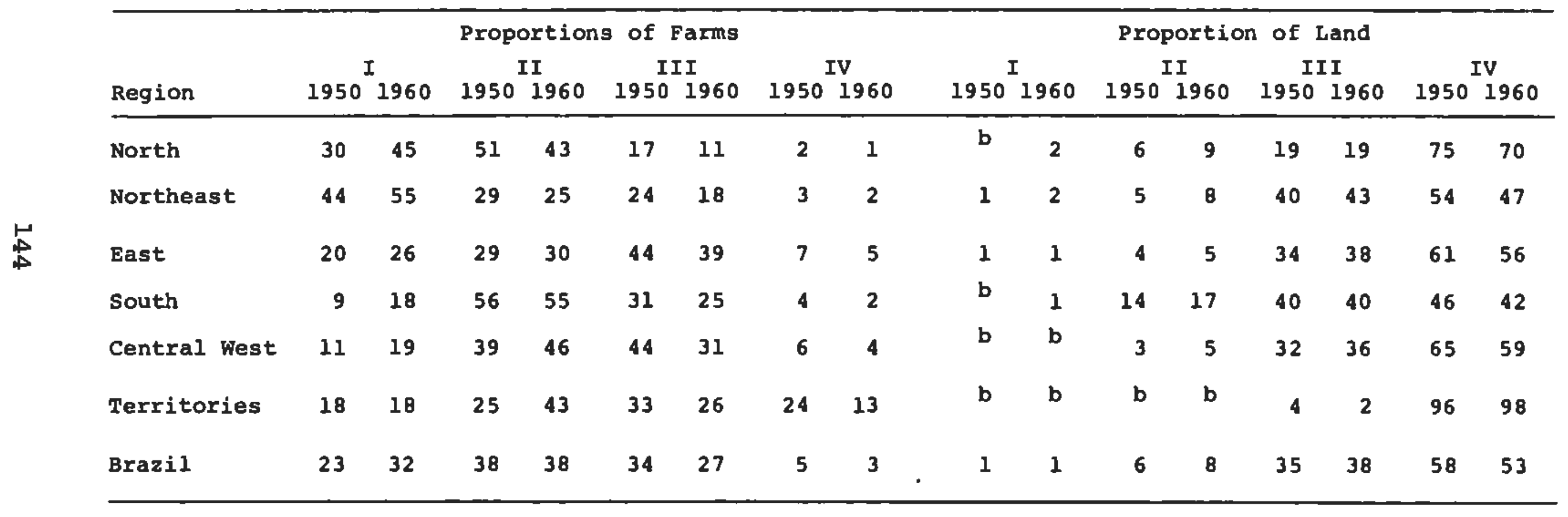

$a_{\text {The data for }} 1960$ are preliminary.

$b_{\text {Less than . } .58 \text {. }}$

Source: CIDA Report. 
the land in farms. Thirty-two percent of the units were sub-familial in 1960, and included only 1 percent of the land area. Three percent of the farms were multi-family large farms, and included 53 percent of the land area. From 1950 to 1960 the percentage of sub-familial units increased substantially, the proportion of family units remained constant, and the fraction of large unitg declined.

\section{The variations among regions are again very} great. It is clear that the very large farms tend to be concentrated in the sparsely populated, underdeveloped territories and in the North--also a very sparsely populated region. At the same time, however, a very large fraction of the farms in the North tend to be sub-familial.

In the south, where the bulk of the agricultural production of Brazil comes from, around 55 percent of the farms are family-size units, with only 2 percent being large and 18 percent being sub-familial units. There did appear to be a substantial increase in the percent of sub-familial farms in this region between 1950 and 1960, however. In the Northeast, with its very heavy concentrations of people, the percentage of sub-familial units is quite high.

In conclusion, these data support those presented previously, in that they indicate a very skewed distribution of land holdings. Comments on the goodness or badness of this situation have been purposely avoided because criteria as to the optimum distribution of land holdings are wanting. It does seem clear, however, that much of the writing on the latifundio problem in Brazil is quite misleading. The analyses typically put forward are usually based on aggregate data, and the regional breakdown presented above shows that the very large farm units occur in the North and in the territories, where the population is quite sparse and the level of economic activity is quite low.

This is not to argue that the labor market is functioning perfectly, or that no rural laborers are being exploited by their employers. However, to answer this question one has to turn to quite different data. A mere examination of the size distribution of land holdings and the productivity of land per size of farm is not helpful, given the quite diverse economic and climatic conditions in Brazil. 
The data above also suggest considerable change in the distribution of land holdings. On the surface they indicate a breaking down of the large units into smaller units. It is useful to delve into this in an attempt to understand more adequately the nature of the process. It will be shown that the increase in the proportion of small farms is a reflection of the colonization process taking place in two important parts of the country.

Data on the change in number of farms and area of farm land between 1950 and 1960 is given in Table 65. The very sharp increase in number of farms is clearly shown--an addition of nearly 1.3 million farms to the almost 2.1 million units in 1950. The bulk of these new farms--nearly 50 percent--are small units of less than 5 hectares, and over 60 percent of the new farms are less than 10 hectares. In contrast, less than 2 percent of the new farms are 200 hectares and over, although these of course span a proportionately larger land area. As a result of these developments, the average farm size declined very substantially from 1950 to 1960 --from 112.5 hectares to 79.4 hectares.

The largest proportion of all new farms was found in the Northeast and the South, although the East was not far behind. However, in all regions except the Central West, well over one-half of the new farms were less than 10 hectares. It is noteworthy that about 150,000 new farm units of less than 10 hectares are found in the state of Maranhão (Northeast) and about 79,000 in the state of Parand (South). Both of these are important areas of new settlement. Among the traditional agricultural states, a high proportion of the new small farms were found in São Paulo $(81,000)$, Pernambuco $(78,000)$, Rio Grande do Sul $(53,000)$, and Paralba $(39,000)$. In these latter areas the new farms tend to represent the breakdown of existing units into smaller units.

The size distribution of holdings of new farm land in the territories is quite different from the rest of Brazil, however. Between 1950 and 1960 there was an increase of over 9 million hectares in the three territories of Acre, Rio Branco, and Amapa (all in the North). Nearly all the additional land was accounted for by the increase in farm land in large farms of 1,000 hectares and over. This suggests that this land is being bought up for speculative purposes. 
TABLE 65

Change in Number of Farms and Area in Farm Land, by Size of Farm, 1950 and 1960

\begin{tabular}{|c|c|c|c|c|c|c|c|c|c|}
\hline \multirow{2}{*}{$\begin{array}{c}\text { Size of } \\
\text { Farm } \\
\text { (hectares) }\end{array}$} & \multirow{2}{*}{\multicolumn{3}{|c|}{$\begin{array}{c}\text { Number of Farms } \\
\text { (thousands) } \\
\text { Differ- } \\
1950 \quad 1960 \text { ence }\end{array}$}} & \multirow{2}{*}{\multicolumn{3}{|c|}{$\begin{array}{c}\text { Total Area } \\
\text { (thousand hectares) } \\
1950 \quad 1960 \quad \begin{array}{c}\text { Differ- } \\
\text { ence }\end{array}\end{array}$}} & \multirow{2}{*}{$\begin{array}{c}\text { Hectares } \\
\text { per Added } \\
\text { Farm }\end{array}$} & \multicolumn{2}{|c|}{$\begin{array}{c}\text { Average } \\
\text { Farm Size }\end{array}$} \\
\hline & & & & & & & & 1950 & 1960 \\
\hline $0-5$ & 459 & 1,034 & 575 & 1,171 & 2,517 & 1,346 & 2.3 & 2.6 & 2.4 \\
\hline $5-10$ & 252 & 466 & 214 & 1,855 & 3,406 & 1,551 & 7.3 & 7.4 & 7.3 \\
\hline $10-200$ & 1,184 & 1,652 & 468 & 53,900 & 69,505 & 15,605 & 33.3 & 45.5 & 42.1 \\
\hline $200+$ & 169 & 190 & 21 & 175,286 & 190,023 & 14,737 & 697.5 & $1,035.2$ & 997.1 \\
\hline All Farms & 2,064 & 3,342 & 1,278 & 232,212 & 265,451 & 33,239 & 26.0 & 112.5 & 79.4 \\
\hline $5000+$ & 4 & 4 & $(65)^{b}$ & 62,035 & 69,604 & 7,569 & $116,449.6$ & $15,115.7$ & $16,695.7$ \\
\hline
\end{tabular}

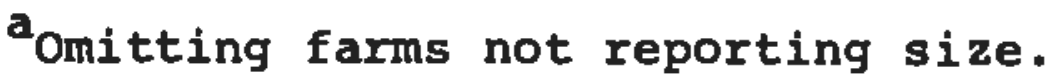

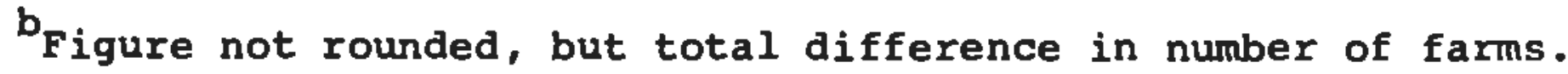

Source: Censo Agrícola 1950; Censo Agrícola Preliminar, 1960. 
TABLE 66

Distribution of New Farms, by Region, 1950-1960

\begin{tabular}{|c|c|c|c|c|c|}
\hline Region & $\begin{array}{c}\text { New } \\
\text { Number } \\
\text { (thousands) }\end{array}$ & Percent & $\begin{array}{c}\text { New Far } \\
10 \text { He } \\
\text { Number } \\
\text { (thousands) }\end{array}$ & $\begin{array}{l}\text { Dder } \\
\text { Percent }\end{array}$ & $\begin{array}{c}\text { Percent New } \\
\text { Farms Under } \\
10 \text { Hectares } \\
\text { of All } \\
\text { New Farms }\end{array}$ \\
\hline North & 60 & 5 & 42 & 5 & 70 \\
\hline Northeast & 422 & 33 & 327 & 41 & 78 \\
\hline East & 294 & 23 & 158 & 20 & 54 \\
\hline South & 429 & 33 & 241 & 31 & 56 \\
\hline $\begin{array}{l}\text { Central } \\
\text { West }\end{array}$ & 80 & 6 & 21 & 3 & 26 \\
\hline Brazil & 1,285 & 100 & 789 & 100 & 61 \\
\hline
\end{tabular}

Source: Censo Agrícola da 1950; Censo Agrícola Preliminar, 1960. 
In summary, then, the tendency to very small units reflects in good part the colonization in new areas such as Parań and Maranhăo. The traditional agricultural regions of the country have recorded relatively little change, although a trend toward the breakdown of large units is evident.

The very small units in the new areas reflect the limited amount of resources which the colonist brings to his endeavors. As some of these units grow and accumulate capital, there w111 undoubtedly be a sizable reorganization of holdings, with those not able to make a go of 1 t elther being forced out or being forced to work as hired men for the units that are growing in size. Some kind of Homestead Act which would bee to 1 t that these new unitg were of reasonable size in the first place, and which would provide credit for the organization of an optimumsize unit, would not only increase the productivity in these areas, but also reduce the adjustment problems to be faced in the future.

\section{Ownership Patterng}

One other aspect of the land input is important before closing this section. Land In Brazil tends to be owned by 1ndividuals. Although data for 1960 are not avallable, in $1950,78.7$ percent of the land in farms was owned by individuals, 12.5 percent by condominium and partnerships, 3.5 percent by corporations (cooperatives and others), .2 percent by char 1table and religlous institutions, and 5.1 percent by public entities. The corporations are owners princlpally of the large farms, with 11.4 percent of the farms of 10,000 hectares or more so owned.

\section{AGRICULTURAL IABOR FORCE}

Data on the agricultural labor force in relation to the total labor force, and crude estimates of relative income levels and their respective changes over time, have already been presented. (See Chapter 2.) One of the gertous lacunae in Brazilian data 1 s the very serlous lack of information concerning labor productivity, levels of income and wage rates, and sources of income. A study by Paiva and Nicholis6 provides valuable information on this, but their sample $1 \mathrm{~s}$ quite small and the study is not completed. 
In this section an attempt is made to provide information which complements that given previously. The major interest is in a brief quantitative analysis of standards of living, the composition of the labor force, and the employment of the farm labor force among product groups.

That labor incomes in rural areas are low goes without saying. (The Inter-American Development Bank has estimated that average real income per capita in 1961 was $\$ 375$, while the average real agricultural income per capita was $\$ 175 ., 7$ The large migration to urban areas, which has already been pointed out, is testimony to this.

That the low incomes in rural areas represent a situation of exploitation, as is so frequently argued, is not nearly so clear, however. Labor which works only with the simplest of tools is not highly productive. (In 1960 the man-land ratio in Brazil was one man per 2.5 hectares. The comparable ratio in Argentina was one man per 19 hectares, and in the United States, one man per 28 hectares. Given the relatively low yields in Brazil, the small amount of capital working with labor is obvious.) Hence, its real product (real wage) cannot be expected to be high. Moreover, a society which invests so little in its rural people in the form of education cannot expect these people to be highly productive.

The cost of living for food products is most likely much lower in rural areas than in urban areas. On the other hand, the product mix available to the rural worker is in general much more limited. A sizable fraction of the agricultural labor force does not participate in the market economy, and hence they do not have many products available to them that their urban brethren have. Moreover, the public services, such as electricity, schools, postal system, and telephone, are either not available or of much lower quality.

\section{Components of the Farm Labor Force}

Data on the distribution of the labor force are not available for 1960. However, the 1950 census indicated that 18.7 percent of the labor force were operators (responsáveis), 33.9 percent were hired labor remunerated in money, 35.9 percent were unpaid family labor, and 11.5 percent were sharecroppers. 
The data for sharecroppers are underestimated, since sharecroppers with administrative responsibilities are classified as operators.

The extent to which these data represent the fraction of labor input from each category is not known. Nor is it known to what extent the proportions have changed since that time. The relatively strong labor market during the decade of the 1950's, with the heavy out-migration from rural areas, may have forced some rather large changes.

The operators are divided into four groups: owners, renters (either through cash rent or sharing), administrators, and occupiers (those who exploit the land without title). In 1950, 66.8 percent of the land in farms was operated by owners, 23.4 percent by administrators, 5.6 percent by renters, and 4.2 percent by occupiers. These data overestimate the role of the owner, since the category includes some types of administrators and renters and, in addition, many owners are absentee landlords.

\section{Product Distribution of the Labor Force}

Data on the distribution of workers among the various major agricultural activities are presented in Table 67. The majority of agricultural workers (persons over 10 years of age employed in agriculture, but excluding the extractive industries in agriculture) were employed in the production of small grains. Next in importance in the absorption of manpower was coffee, followed by sugarcane, cotton, and livestock. Data for 1960 are not available, but it is not thought that these proportions have changed greatly. In recent years the relative employment in coffee may have declined somewhat, while the employment in livestock production may have increased somewhat.

\section{CAPITAL FORMATION}

Considered as a sector, it would appear that there has been considerable capital formation in Brazilian agriculture in recent years. As shown earlier, the land in farms increased 18 percent from 1950 to 1960. This has most likely continued at the same or 
TABLE 67

Distribution of Workers by Major Land Use, 1950

(thousands)

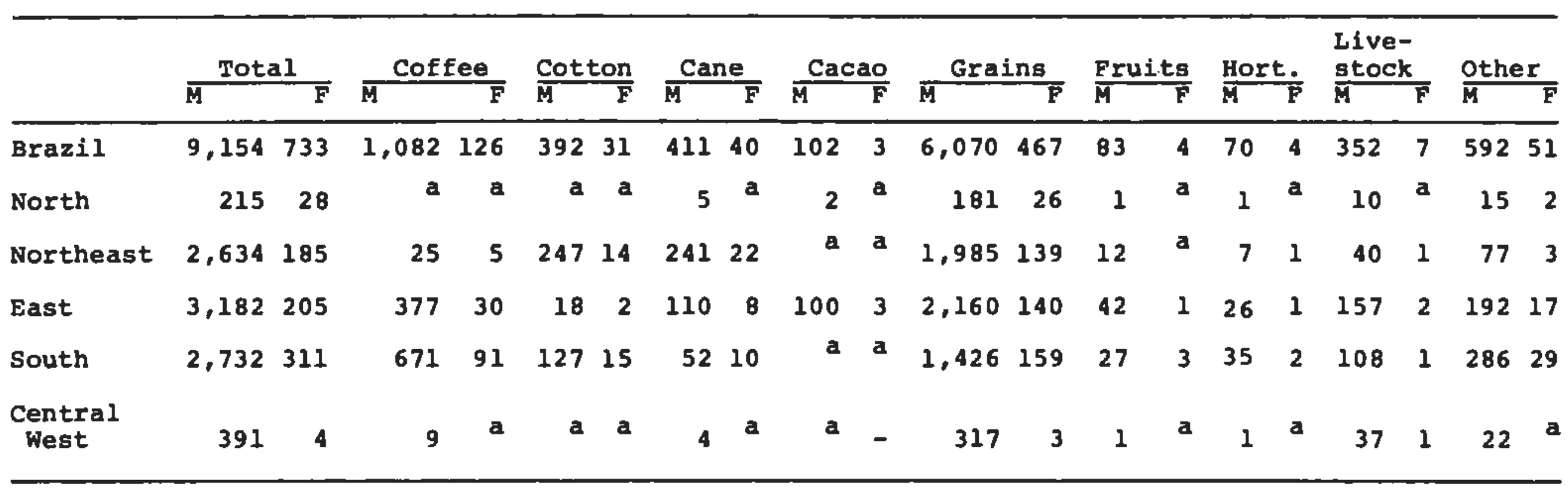

Note: $\mathbf{M}=$ Males; $\mathbf{F}=$ Femalea.

ansignificant.

Source: Censo Demográfico de 1950. 
even a higher rate since 1960 . The livestock herd appears to have increased considerably; and, in the period since 1950, a sizable investment has been made in the stock of coffee trees. This investment may have tapered off in recent years with the extensive eradication programs; but even with eradication, the replacement of old, degenerated plantings with new, more productive ones may represent some net capital formation.

Although the total stock of capital has been increasing, it is important to recognize that there has been very little deepening of capital in the agricultural sector. A more rapid expansion in land in farms than in the labor force has led to somewhat more capital per man, on the average. The slow rise in educational attainment in rural areas suggests that more is being invested in rural people. But in general, a rapid mechanization or capital-intensive form of agriculture has not developed.

A majority of Brazilian farmers still prepare, plant, cultivate, and harvest their crops with the most primitive of tools. Capital in the form of machinery and equipment is quite limited; and except for a few areas, the principal inputs are land and labor. Environmental conditions are such that large investments in animal shelters are not necessary, but even capital formation in machinery shelters and other fixed facilities is quite limited.

The principal forms of capital are therefore land, livestock heards, and, for the coffee sector, the investment in the tree stock and the coffee processing equipment. In large parts of Brazil the use of modern machines is rendered difficult by the topography, but this does not explain the lack of draft animals and the simple equipment drawn by animals. The answer more likely lies in the relative price of inputs and the failure to develop industries which supply the simple kinds of machines and equipment for the agricultural sector.

\section{Mechanization}

Census data fully reflect the extremely limited use of farm equipment. In 1950, 73 percent of all farms employed only human labor using the hoe and. other hand-operated tools, and almost 27 percent used animal labor. Of the farms using draft animals, 
about 82 percent were in the South. Most revealing is the fact that the steel or wood plow was unknown on three-fourths of the farms.

By 1960 the percentage of farms using only human power in agricultural activities had actually increased to 76 percent. The percent age of farms using draft animals had declined somewhat to 22 percent, but the fraction using mechanical power was still less than 1 percent. The fraction of farms using a combination of animal and mechanical power increased slightly. The percentage of farms using other than human power in on-the-farm processing activities was also exceedingly small.

Between 1950 and 1960 there was a sharp increase in the number of tractors and a more modest increase in the number of plows. The total number of tractors increased from about 8,400 in 1950 to 63,500 in 1960,8 and the number of plows--most of which are wooden frames with steel shovels--from 714,000 to $1 \mathrm{mill}$ ion. Despite these increases, the degree of mechanization actually decreased. Between 1950 and 1960 the increase in number of farms was nearly 1.3 million units.

Another important aspect of the increase in number of tractors and plows is that they were added in the southern part of the country, which had the bulk of these two types of equipment in 1950. For example, the data in Table 70 indicate that 39,000 of the 55,000 new tractors and 190,000 of the approximately 318,000 new plows were added in São Paulo and Rio Grande do Sul. A sharp increase was also noted in Santa Catarina and Parana. In the rest of Brazil, only about 11,000 tractors and 35,500 plows were added.

The limited use of machinery and equipment can be assessed by comparing the number of tractors or plows with the number of farms, with the hectares in total farm land, and with hectares in crops. In the four states where tractors and plows were most numerous, there was only one tractor for every 22 farms, for every 1,182 hectares in farm land, and for every 261 hectares in crop land in 1960 . In contrast, in the remainder of the country there were 175 farms, 16,207 hectares in farm land, or 1,303 hectares in crop land for each tractor. 
TABLE 68

Use of Machinery and Draft Animals, by Region, 1950

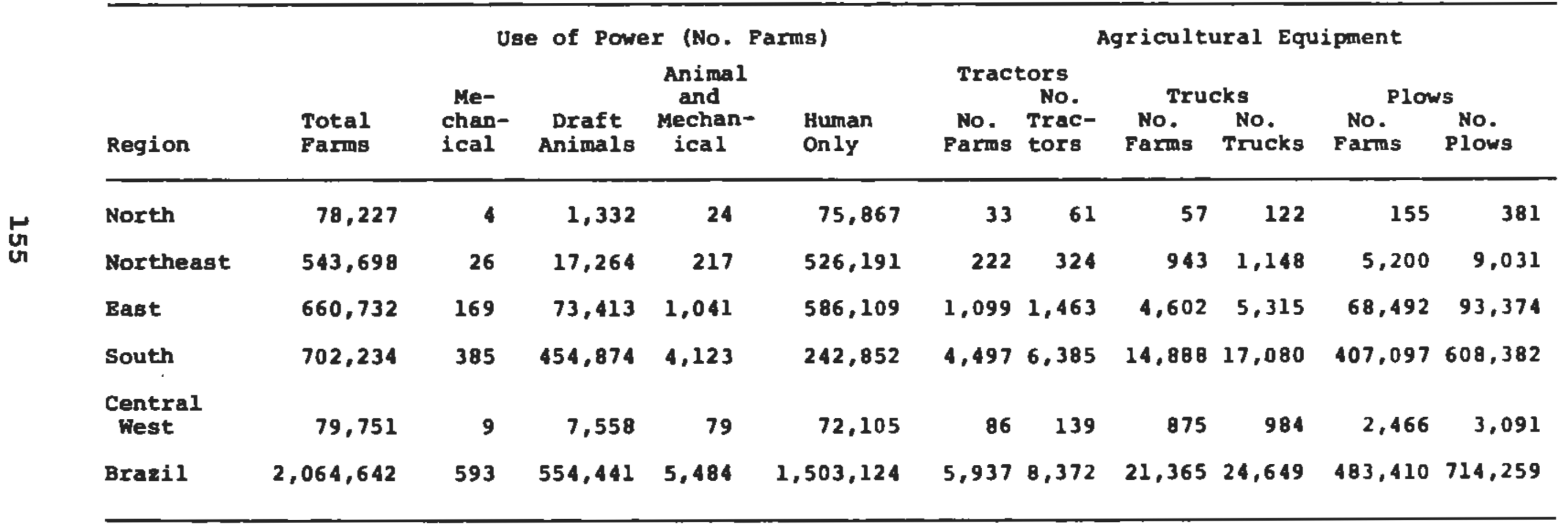

Source: Censo Agrícola da 1950. 
TABLE 69

Use of Machinery and Draft Anlmals, by Region, 1960

\begin{tabular}{|c|c|c|c|c|c|c|c|c|c|}
\hline \multirow[b]{3}{*}{ Region } & \multicolumn{9}{|c|}{ Number of Establighments, According to Kind of Power Used } \\
\hline & \multicolumn{5}{|c|}{ Agriculture } & \multicolumn{4}{|c|}{ Processing } \\
\hline & Total & $\begin{array}{l}\text { Mechan- } \\
\text { ical }\end{array}$ & $\begin{array}{l}\text { Draft } \\
\text { Animals }\end{array}$ & $\underset{\text { Mechanical }}{\text { Animal }}$ & $\begin{array}{l}\text { Human } \\
\text { Only }\end{array}$ & $\operatorname{Total}^{\mathbf{a}}$ & $\begin{array}{l}\text { Mechan- } \\
\text { ical }\end{array}$ & $\begin{array}{l}\text { Draft } \\
\text { Animals }\end{array}$ & $\underset{\text { Mechanical }}{\text { Animal + }}$ \\
\hline North & 138,241 & 253 & 206 & 34 & 137,748 & 93,442 & 1,528 & 1,039 & 340 \\
\hline Northeast & 961,627 & 887 & 34,267 & 945 & 925,528 & 246,733 & 5,713 & 11,868 & 1,891 \\
\hline Bast & 953,520 & 2,979 & 93,058 & 3,602 & 853,881 & 303,452 & 10,062 & 32,440 & 5,000 \\
\hline South & $1,124,989$ & 11,949 & 593,638 & 24,892 & 494,510 & 102,699 & 4,317 & 20,050 & 1,724 \\
\hline $\begin{array}{c}\text { Central } \\
\text { West }\end{array}$ & 159,392 & 877 & 12,941 & 1,004 & 144,570 & 37.573 & 625 & 2,132 & 504 \\
\hline Brazil & $3,337,769$ & 16,945 & 734,110 & 30,477 & $2,556,237$ & 783,879 & 22,245 & 67.529 & 9,459 \\
\hline
\end{tabular}

ancludes establishments that utilize only manual processes and those that made no declaration of source of power.

Source: Anuario Estatistico do Brasil 1967 (Rio de Janeiro: IBGE, 1968 ). 
TABLE 70

Number of Farms, Tractors, and Plows, by Specified Areas, 1950 and 1960

\begin{tabular}{|c|c|c|c|c|c|c|}
\hline \multirow[b]{2}{*}{ State or Area } & \multicolumn{2}{|c|}{$\begin{array}{l}\text { Total Farms } \\
\text { (thousands) }\end{array}$} & \multirow{2}{*}{\multicolumn{2}{|c|}{$\begin{array}{cr}\text { No. Tractors } \\
1950 & 1960\end{array}$}} & \multicolumn{2}{|c|}{ No. Plows } \\
\hline & 1950 & 1960 & & & 1950 & 1960 \\
\hline $\begin{array}{l}\text { Rio Grande } \\
\text { do Sul }\end{array}$ & 286.7 & 382.1 & 2,245 & 16.675 & 312,001 & 440,467 \\
\hline São Paulo & $221 \cdot 6$ & 318.8 & 3,819 & 28,101 & 224,947 & 286,580 \\
\hline Santa Catarina & 104.4 & 159.0 & 41 & 1,049 & 41,029 & 81,259 \\
\hline Paraná & 89.5 & 271.2 & 280 & 4,996 & 30,405 & 82,324 \\
\hline Subtotal & 702.2 & $1,131.1$ & 6,385 & 50,821 & 608,382 & 890,630 \\
\hline Remaining States & $1,359.3$ & $2,211.8$ & 1,969 & 12,624 & 105,788 & 141,228 \\
\hline Territories & 3.1 & 6.6 & 18 & 48 & $\begin{array}{r}.89 \\
\end{array}$ & 72 \\
\hline Subtotal & $1,362.4$ & $2,218.4$ & 1,987 & 12,672 & 105,877 & 141,300 \\
\hline Brazil & $2,064.6$ & $3,349.5$ & 8,372 & 63,493 & 714,259 & $1,031,930$ \\
\hline
\end{tabular}

Source: Censo Agrícola da 1950; Censo Agrícola Preliminar, 1960. 
It is worth noting that the increase in the number of plows has not kept up with the increase in the number of farms or in the number of hectares in crop land, although it has kept up with the amount of total land in farms. Hence the number of farms and of hectares in crop land per plow has increased over the 10-year period.

It is important that a proper perspective be kept on this process of mechanization. In a relative sense there was a high degree of mechanization during the decade. For example, the number of farms with mechanical power increased 28-fold and those with animal plus mechanical power increased nearly six-fold, while the number of farms using only human power increased only 68 percent and those using animal power only 32 percent.

However, the increase was on a small base; and with the rapid increase in crop land and in number of farms, the aggregate ratios tended to decline. In the aggregate, therefore, mechanization did not make much progress.

The regional dimension of the problem is also important. The southern part of the country has experienced a fairly rapid rate of mechanization. Other parts of the country, on the other hand, have been largely bypassed.

\section{Regional Aspects}

More comprehensive regional data on resource use are given in Table 72. Labor, tractors, and plows per farm and per hectare are expressed as a percentage of the national average.

It is interesting to note that labor per farm does not vary greatly from one region to another, although labor per hectare does. Labor per farm is lowest in the North, and highest in the East. Labor per hectare is highest in the Northeast, however, and lowest in the Central west. The relative difference is indeed great. Both the East and the South are well above the national average in labor per hectare, and the North is considerably below the average.

Some important regional shifts took place between 1950 and 1960. In the North, labor per farm 
Relation Between Number of Farms, Number of Hectares in Farm Land or in Crop Land, and Farm Equipment, by Specified Areas, 1950 and 1960

\begin{tabular}{llll} 
& Four- & & \\
State & Remainder & \\
Item & Areaa & of Brazil & Brazil \\
\hline
\end{tabular}

Tractors

No. Farms/Tractor

1950

1960

110

686

175

No. Hectares in Farm

Land/Tractor

1950

8,524

89,473

1,182

16,207

27,737

1960

No. Hectares in Crop

Land/Tractor

1950

1960

1,376

5,187

1,303

2,281

469

Plows

No. Farms/Plow

1950

1. 2

12.9

15.9

2.9

1.3

3.2

No. Hectares in Farm Land/Plow

1950

1960

$89.5 \quad 1,679.1$

325.1

$64.51,453.5$

257.2

No. Hectares in Crop

Land/Plow

$\begin{array}{lrrr}1950 & 14.4 & 97.3 & 26.7 \\ 1960 & 14.9 & 116.8 & 28.8\end{array}$

Parana.

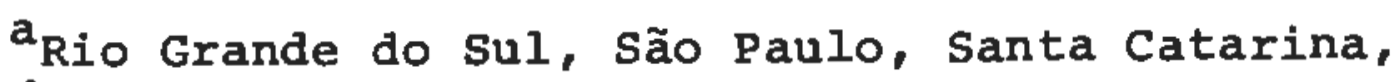

Source: Censo Agrícola da 1950, Censo Agrícola Preliminar, 1960 . 
Labor, Tractors, and Plows per Farm and per Hectare, as a Percent of the National Average, 1950 and 1960

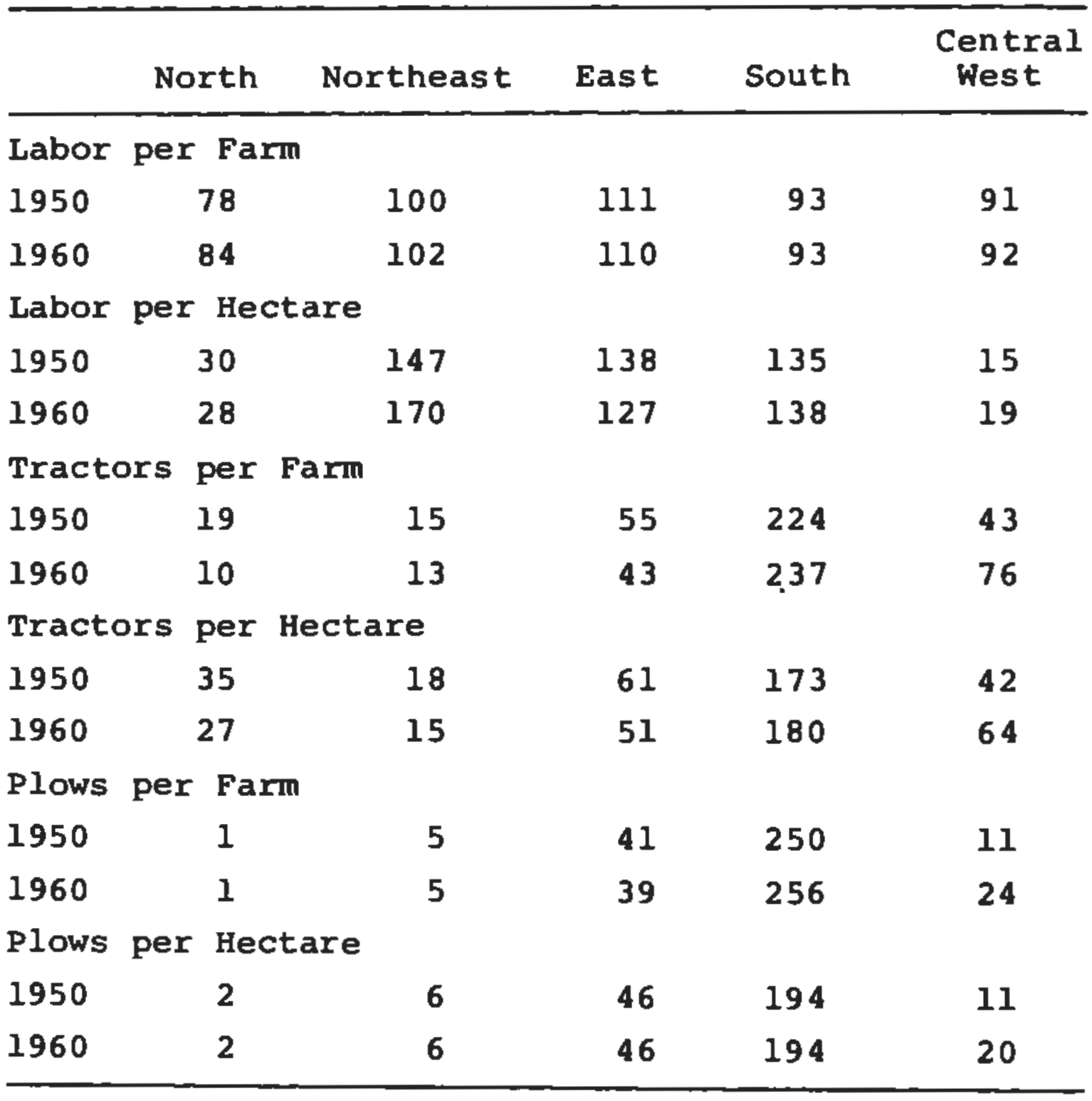

Source: Anuário Estatistico do Brasil (Rio de Janeiro; IBGE, various years). 
rose in relation to the national average, while labor per hectare declined. This appears to reflect the relatively large increase in land in farms in this area, as a result of the increased colonization.

In the Northeast, labor per hectare in farms increased in relation to the national average between 1950 and 1960 , as was the case in the Central West. In the East, however, labor per hectare declined in relation to the national average.

The very wide disparity in the degree of mechanization is seen in the rest of the table. The concentration of tractors and plows in the south is clearly demonstrated. Equally important, the regional disparity increased from 1950 to 1960 for all components except for plows per hectare. With the exception of the latter component, the south also increased in relation to the national average for all categories. There has also been a relatively high rate of mechanization in the Central West.

\section{The structure of Capital}

Data on the structure of capital in the agricultural sector, and its changes between 1940 and 1965 , are presented in Table 73. The data from 1940 are from the census for that year, while those for 1965 are taken from an enumeration of all farms made in that year by IBRA. Although these latter data have been criticized by some researchers, they are used in lieu of data from the 1960 census, which are not yet published. Hopefully, the data reflect in gross terms the structure of capital in this recent period.

In 1940,72 percent of the capital was in the form of land and buildings, and 23 percent in animals. Only a small fraction of the capital was in the form of machines and vehicles. Regional differences in the structure were not great, with the exception of the Central West, which had relatively less capital in the form of land and relatively more in the form of animals. At that time the central West was a very extensive cattle grazing area, and the land had a relatively low value.

The concepts used for the 1965 data are not directly comparable with those used for 1940. For example, the data show a substantial decline in the 


\section{TABLE 73}

Percentage Distribution of Capital, by Form and Region, 1940 and 1965

\begin{tabular}{|c|c|c|c|c|c|c|}
\hline & North & Northeast & East & South & $\begin{array}{l}\text { Central } \\
\text { West }\end{array}$ & Brazil \\
\hline & \multicolumn{6}{|c|}{1940} \\
\hline $\begin{array}{l}\text { Land } \\
\text { Buildings } \\
\text { Subtotal }\end{array}$ & $\begin{array}{l}46.23 \\
20.74 \\
66.97\end{array}$ & $\begin{array}{l}55.33 \\
18.31 \\
73.64\end{array}$ & $\begin{array}{l}57.10 \\
13.87 \\
70.97\end{array}$ & $\begin{array}{l}59.38 \\
15.56 \\
74.94\end{array}$ & $\begin{array}{r}42.90 \\
11.87 \\
54.77\end{array}$ & $\begin{array}{l}57.05 \\
15.24 \\
72.29\end{array}$ \\
\hline \multirow[t]{2}{*}{$\begin{array}{l}\text { Animals } \\
\text { Machines } \\
\text { Vehicles }\end{array}$} & $\begin{array}{r}28.19 \\
3.16 \\
1.69 \\
100.00\end{array}$ & $\begin{array}{r}22.67 \\
2.54 \\
1.15 \\
100.00\end{array}$ & $\begin{array}{r}25.13 \\
2.38 \\
1.52 \\
100.00\end{array}$ & $\begin{array}{r}19.70 \\
2.75 \\
2.61 \\
100.00\end{array}$ & $\begin{array}{r}42.71 \\
1.24 \\
1.27 \\
100.00\end{array}$ & $\begin{array}{r}23.21 \\
2.53 \\
1.98 \\
100.00\end{array}$ \\
\hline & \multicolumn{6}{|c|}{1965} \\
\hline $\begin{array}{l}\text { Land } \\
\text { Permanent }\end{array}$ & 48.79 & 39.89 & $43.30^{\circ}$ & 44.49 & 56.97 & 44.94 \\
\hline $\begin{array}{l}\text { Crops } \\
\text { Subtotal }\end{array}$ & $\begin{array}{r}8.38 \\
57.37\end{array}$ & $\frac{8.27}{48.16}$ & $\frac{7.25}{50.55}$ & $\frac{9.97}{54.46}$ & $\frac{2.24}{59.21}$ & $\begin{array}{r}8.40 \\
53.34\end{array}$ \\
\hline Buildings & 2.58 & 2.38 & 3.26 & 8.33 & 2.55 & 5.83 \\
\hline
\end{tabular}




\begin{tabular}{|c|c|c|c|c|c|c|}
\hline & North & Northeast & East & South & $\begin{array}{c}\text { Central } \\
\text { West }\end{array}$ & Brazil \\
\hline $\begin{array}{l}\text { Real estate } \\
\text { Animals } \\
\text { Equipment } \\
\text { Other }\end{array}$ & $\begin{array}{l}59.95 \\
17.32 \\
10.05 \\
12.68\end{array}$ & $\begin{array}{r}50.54 \\
16.56 \\
26.88 \\
7.01\end{array}$ & $\begin{array}{r}53.81 \\
21.26 \\
19.13 \\
5.79\end{array}$ & $\begin{array}{r}62.79 \\
14.16 \\
15.64 \\
7.40\end{array}$ & $\begin{array}{r}61.76 \\
21.47 \\
13.26 \\
3.52\end{array}$ & $\begin{array}{r}59.17 \\
16.81 \\
17.31 \\
6.72\end{array}$ \\
\hline
\end{tabular}

Source: 1940 census, as reported in Anuario Estatistico do Brasil 1965 (Rio de Janier̃o: $\bar{I} B G E, 1967)$.

A Estrutura Agraria Brasileria (Rio de Janeiro: IBRA, 1968 ). 
percent of capital in buildings between 1940 and 1965. However, it appears that much of what was classified as equipment in 1965 may have been buildings in 1940. This is especially likely to be the case for the sugar mill and the equipment used with coffee.

With this reservation in mind, it does appear that real estate was relatively less important in 1965 than in 1940, reflecting some increase in reproducible capital. Animals also appear to have declined in relative importance. On a regional basis, the relative importance of real estate in the Central West appears to have increased, while the relative importance of animals appears to have declined. This probably reflects an increase in the value of land in this area as a result of the construction of Brasilia and the roads connecting it to other urban centers, and the increased production of crops in the region.

The relatively large share of capital in the form of equipment in the Northeast probably reflects the importance of the sugar mill. These tend to be on-the-farm operations.

\section{Regional Distribution of Capital}

Data on the distribution of capital by regions are presented in Table 74. (These data come from the same two sources, and are subject to the same reservations as those in Table 73.$)$ The concentration of the stock of capital in the South and East is clearly evident. The South alone has almost 50 percent of the total. A comparison of these data with the regional distribution of the agricultural labor force presented earlier goes a long way in explaining the rather large difference in incomes between the Northeast and the South.

The relative stocks of capital tended to be highly correlated among the regions in 1940. Major exceptions were the relatively lower percentage of capital in vehicles in the Northeast, the relatively higher fraction of capital in vehicles in the South, and the relatively high fraction of capital in animals in the Central West. 
It is interesting to note that the share of the total stock of capital concentrated in the South actually increased by 1965. The percentage share went up from 48 to 54, and this on an already large base. The Central West also gained relatively, while the East and Northeast declined relatively. The decline in the East was especially large.

The correlations among the relative stocks of capital appear to be somewhat less in 1965 than they were in 1940, although this may be due in part to the difference in aggregation. This same difference in aggregation prevents a more systematic analysis of the relative changes by component.

\section{THE USE OF MODERN INPUTS}

Brazil has an agriculture that is a mixture of the old and the new. The producers in some areas, particularly in the south central, are progressive administrators who use modern practices of cultivation, fertilizers, and other advanced agricultural methods. In contrast, most other farmers still use primitive agricultural techniques. Rural people in general have only limited formal education, which limits their possibilities of accepting and assimilating modern technology.

With a few exceptions, modern inputs are not extensively used in Brazil. Insecticides, fungicides, fertilizers, medicines and preventives for livestock, and mineral supplements for livestock, for example, are used only in very restricted areas, and with a very limited number of products.

One of the paradoxes of Brazilian agriculture is, of course, the fact that there are exceptions to this general rule. Japanese producers of tomatoes in the state of São Paulo, for example, have one of the highest levels of technology anywhere in the world.9 They use large quantities of fertilizers, follow regular spray schedules for insect and disease control, and use the most modern practices in producing their product. This appears to have very little spillover to other producers or products, however.

A second example is the production of cotton in são Paulo. Through a state monopoly on seed, and 


\section{TABLE 74}

Percentage Distribution of Capital, by Region, 1940 and 1965

\begin{tabular}{|c|c|c|c|c|c|c|}
\hline & North & Northeast & East & South & $\begin{array}{c}\text { Central } \\
\text { West }\end{array}$ & Brazil \\
\hline & \multicolumn{6}{|c|}{1940} \\
\hline $\begin{array}{l}\text { Land } \\
\text { Buildings } \\
\text { Animals } \\
\text { Machines } \\
\text { Vehicles } \\
\text { Total }\end{array}$ & $\begin{array}{l}1.17 \\
1.95 \\
1.73 \\
1.79 \\
1.00 \\
1.43\end{array}$ & $\begin{array}{r}12.51 \\
15.49 \\
12.60 \\
12.98 \\
7.48 \\
12.90\end{array}$ & $\begin{array}{l}32.22 \\
29.29 \\
34.86 \\
30.32 . \\
24.68 \\
32.19\end{array}$ & $\begin{array}{l}50.00 \\
49.02 \\
40.77 \\
52.22 \\
63.34 \\
48.03\end{array}$ & $\begin{array}{r}4.10 \\
4.25 \\
10.04 \\
2.68 \\
3.50 \\
3.13\end{array}$ & $\begin{array}{l}100.00 \\
100.00 \\
100.00 \\
100.00 \\
100.00 \\
100.00\end{array}$ \\
\hline
\end{tabular}




$\begin{array}{lllllrl}\text { Land } & 1.94 & 10.44 & 21.84 & 53.74 & 12.04 & 100.00 \\ \text { Permanent } & 1.83 & 11.59 & 19.58 & 64.47 & 2.53 & 100.00 \\ \quad \text { Crops } & 0.79 & 4.80 & 12.67 & 77.59 & 4.16 & 100.00 \\ \text { Buildings } & 1.84 & 11.60 & 28.68 & 45.76 & 12.13 & 100.00 \\ \text { Animals } & 1.04 & 17.59 & 25.05 & 49.05 & 7.27 & 100.00 \\ \text { Equipment } & \frac{1.37}{1.79} & \frac{12.28}{11.77} & \frac{19.54}{22.66} & \frac{59.83}{54.29} & \frac{4.97}{9.50} & \frac{100.00}{100.00} \\ \text { Other } & \text { Total } & & & \end{array}$

Source: 1940 census, as reported in Anuário Estatístico do Brasil 1965 (Rio de

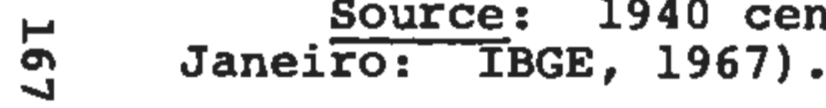

A Estrutura Agrária Brasileira (Rio de Janeiro: IBRA, 1968). 
perhaps one of the strongest experiment stations in Latin America, São Paulo has succeeded in substantially raising the yield of cotton. Only the recommended variety of cotton was sold to the farmers, and the seed was treated to control disease before it was distributed. In this case, the spillover into the state of Parana has been great.

In the North, the production of black pepper has brought a rather high level of technology, with the use of modern inputs. Under these conditions it has been possible to establish a permanent agriculture for the first time in that area.

In Rio Grande do Sul, Brazil's southernmost state, a rather extensive artificial insemination program has been carried out. High-quality semens have been imported from the United states and other parts of the world, and a considerable upgrading of the cattle herd has taken place.

Hybrid corn has been adopted rather extensively in many parts of Brazil. However, the average yield has increased only slightly, in part because the complementary inputs, such as commercial fertilizer, are not used to a sufficient extent to gain the maximum benefit from improved varieties.

These examples of the use of modern inputs are not generalized, however. Much crop production is carried out with a man, a hoe, and land, despite the fact that southern Brazil is developing a modern agriculture. Cattle are turned out to pasture to fend for themselves, with little or no disease or pest control, and little or no supplementation of rations. The weight loss during the dry season is great, as is the loss from parasites, disease, and insects.

Brazilian soils are inherently low in the major plant nutrients. This carries over into the grasses and plants; and as a consequence, cattle tend to suffer from phosphorus and calcium deficiencies, in addition to deficiencies of trace elements. Experiments have shown that the addition of phosphorus and calcium to cattle rations will increase the rate of gain and raise the fertility levels of breeding stock.

Data on the use of modern inputs is available only in bits and pieces. 10 The most extensive data 
available are on commercial fertilizers. We turn to these data as a means of documenting the low level of usage of modern inputs. 11

Except for the arid zone of the Northeast, the soils currently cultivated in Brazil are so acid that they limit the yields of the principal crops. It is estimated that of the 28.5 million hectares cultivated in 1963 , at least $10 \mathrm{million}$ needed lime. To increase the $\mathrm{pH}$ one unit--for example, from 4.5 to 5.5--on $4 \mathrm{milli}$ on hectares of acid soils, 30 million metric tons of lime would have been necessary over an eight-year period. That is, 3.75 million metric tons per year. This should be compared with the estimated production of lime for agriculture in 1963, which was on the order of 250,000 metric tons.

Many of the soils in Brazil have a natural fertility that is relatively low. Even the new areas that are being settled have a relatively high acidity and a low nutrient content. The nitrogen accumulation in the first couple of inches of topsoil is used up in two to three years after clearing; and then the soils become deficient in nitrogen, phosphorus, and potash, as well as in certain trace elements. The most serious deficiency appears to be in phosphorus.

Despite these inherent deficiencies, Brazil is one of the lowest fertilizer users in the world. For the period 1956-1958, only 8.5 kilograms of commercial fertilizer per hectare of arable land was used, compared with $30.9 \mathrm{kilos}$ for the United states and approximately $450 \mathrm{kilos}$ for Holland and New zealand. (The yields in the United States were, on the average, twice those in Brazil, and those in Holland and New Zealand were four times greater.)

More than 95 percent of the Brazilian producers did not use commercial fertilizer in the early 1960's. The quantities of fertilizer used were sufficient to fertilize adequately only 8 percent of the cultivated area of the country. Of the mineral elements taken from the soil, not more than 12 percent were being replaced. Moreover, in general no fertilizer is used on the immense areas in pasture that supply rations for approximately 60 million head of cattle and 20 million head of sheep. 
Despite these low levels of use, the consumption of fertilizers increased rapidly in the decade 19531963, especially in the intensely cultivated areas of São Paulo, Rio Grande do Sul, and other specialized areas. The consumption of phosphorus has been the greatest of the three major nutrients, followed by potash and then by nitrogen. Some 60 to 80 percent of the nutrients are used in the central states, which reflects primarily the influence of São Paulo and Parana. The South, especially Rio Grande do Sul, has been a relatively heavy user of phosphate fertilizers.

From 1953 to 1963, the consumption of nitrogen increased 221 percent, phosphate 133 percent, and potash 224 percent. Consumption has varied a great deal from year to year. The peak consumption of nitrogen occurred in 1960, dropped off after that, and by 1963 had not attained the previous high. The peak consumption of phosphorus occurred in 1958, and by 1963 it had not yet reattained that level. Most of this was due to the decline in consumption in the South. Potash consumption also reached its peak in 1960 and had not recovered by 1963.

In 1965 attempts were made to stimulate the use of fertilizer through a credit program and an improved distribution system. The impact of this program is shown in Table 76. Apparent consumption approximately doubled between the 1962/64 period and 1968 .

One other piece of information that documents the low level of use of modern inputs in Brazilian agriculture is presented in Table 76. Of the over 3 million agricultural establishments in 1960 , only some 116,000 used electrical power. of these, almost half provided the energy from their own sources of power. Moreover, the major fractions of the farms using electrical energy were concentrated in the East and South.

\section{PRODUCTIVITY}

A discussion of the level of productivity in the agricultural sector is presented in this final section. Although the analysis is not as comprehensive as would be desired, the limited data available indicate that the level of productivity is quite low, and in the aggregate has not changed very much over time. 
TABLE 75

Apparent Consumption of Fertilizer, by Region, 1953-1963

(tons)

\begin{tabular}{|c|c|c|c|c|c|c|c|c|c|c|c|c|}
\hline \multirow[b]{2}{*}{ Year } & \multicolumn{2}{|c|}{ Nitrogen (N) } & \multirow[b]{2}{*}{ south $^{3}$} & \multirow[b]{2}{*}{ Total } & \multicolumn{4}{|c|}{ Phosphate $\left(\mathrm{P}_{2} \mathrm{O}_{5}\right)$} & \multicolumn{4}{|c|}{ Potash $\left(k_{2} O\right)$} \\
\hline & Northl & Central ${ }^{2}$ & & & North & Central & South & Total & North & Central & South & Total \\
\hline 1953 & 3,449 & 15,366 & 1,766 & 20,581 & 5,402 & 35,273 & 18,542 & 59,217 & 4,789 & 23,770 & 2,667 & 31,226 \\
\hline 1954 & 2,329 & 13,004 & 2,432 & 17,765 & 5,670 & 40,311 & 24,242 & 70,223 & 2,773 & 22,329 & 3,247 & 28,349 \\
\hline 1955 & 3,642 & 16,808 & 2,500 & 22,950 & 7,666 & 55,594 & 17.710 & 80,970 & 4,683 & 38,064 & 5,976 & 49,523 \\
\hline 1956 & 2,631 & 22,212 & $5,39 \mathrm{~B}$ & 30,241 & 6,824 & 53,099 & 25,381 & 85,304 & 4,461 & 30,757 & 6,414 & 41,632 \\
\hline 1957 & 5,064 & 18,955 & 4,537 & 28,556 & 9,495 & 72,413 & 36,784 & 118,692 & 5,521 & 44,722 & 9,947 & 60,190 \\
\hline 1958 & 4,624 & 28,739 & 8,036 & 41,399 & 11,468 & $B 7,453$ & 44,427 & $143,34 \mathrm{~B}$ & $5,2 \mathrm{B2}$ & 45,134 & 14,606 & 65,022 \\
\hline 1959 & 3,392 & 35,020 & 6,371 & 44,783 & 13,640 & 70,703 & 39,661 & 124,004 & 4,634 & 43,918 & 8,874 & 57,426 \\
\hline 1960 & 4,943 & 55,333 & 6,483 & 66,759 & 13,159 & 77,644 & 40,789 & 131,592 & 5,725 & 87,315 & 13,056 & 106,096 \\
\hline 1961 & 3,008 & $45,76 \mathrm{~B}$ & 6,287 & 55,063 & 10,689 & 85,710 & 22,568 & 118,767 & 5,471 & 55,716 & 9,539 & 70,726 \\
\hline 1962 & 5,208 & 40,775 & 6,912 & 52,895 & 12,098 & 88,119 & 21,992 & 122,209 & 7,130 & 54,352 & $B, 846$ & $70,32 \mathrm{E}$ \\
\hline 1963 & 5,629 & 52,942 & 7,514 & 66,085 & 11,091 & 98,355 & 28,793 & 138,239 & 10,625 & 77,045 & 13,512 & $101,1 \mathrm{B2}$ \\
\hline
\end{tabular}

${ }^{1}$ Includes Bahia, Sergipe, Alagoas, Pernambuco, Parafba, Rio Grande do Norte, Ceará, Maranhão, northern Para, and the northern two-thirds of Goids.

${ }^{2}$ Includes Minas Gerias, Espirito Santo, Rio de Janeiro, Parand, São Paulo, and southern Goiás.

${ }^{3}$ Includes Rio Grande do Sul and Santa Catarina.

Source: Recommendations for Manufacture-Distribution of Agricultural Minerals in Brazil (Manhattan, Kan.: Agri Regearch, Inc.; and Wichita, Kan,: Litwin Engineering Co., Inc., 1964). 
TABLE 76

Establishments Using Electrical

Energy, 1960

\begin{tabular}{lrrrr}
\hline Region & Total & \multicolumn{1}{c}{$\begin{array}{c}\text { Own } \\
\text { Power }\end{array}$} & $\begin{array}{c}\text { Acquired } \\
\text { Power }\end{array}$ & $\begin{array}{c}\text { Own and } \\
\text { Acquired } \\
\text { Power }\end{array}$ \\
\hline North & 383 & 286 & 49 & 48 \\
Northeast & 3,171 & 1,921 & 908 & 342 \\
East & 36,406 & 23,651 & 11,061 & 1,694 \\
South & 74,192 & 28,253 & 41,500 & 4,439 \\
Central West & 1,644 & 1,220 & 302 & 122 \\
Brazil & 115,796 & 55,331 & 53,820 & 6,645 \\
\hline
\end{tabular}

Source: Anuario Estatistico do Brasil 1967 (Rio de Janeiro: IBGE, 1968).

\section{Crop Yields}

Data on the yields of the 16 most important crops are presented in Table 77 , with the trends summarized in Table 78. The picture is at best a very mixed one. Some crops have had rather substantial increases in yields, while others have had decreases in average yields over time.

In Table 78 two recent time periods are provided for comparison. The four crops for which significant increases in yields have been obtained are tomatoes, peanuts, cotton, and potatoes.* All of these except cotton are relatively unimportant economically.

The yield of coffee had increased by 1960-1962, but declined thereafter. Corn had increased in yields when compared with the base period, but a look at Table 77 indicates that comparable yields were being obtained in 1950 and 1951. Mandioca had an increase in yield in the 1964-1966 period, but

*Yields of cotton and peanuts were low in the 196466 period because of unfavorable weather conditions. 
TABLB 77

Ylelds of Selected Crops, 1950-1966 (kg. per hectare)

\begin{tabular}{|c|c|c|c|c|c|c|c|c|c|c|c|c|c|c|c|c|}
\hline \multirow{2}{*}{$\frac{\text { Year }}{1950}$} & \multicolumn{2}{|c|}{$\begin{array}{c}\text { Cocoa } \\
\text { Yield Index }\end{array}$} & \multicolumn{2}{|c|}{$\begin{array}{l}\text { Coffee } \\
\text { Yield Index }\end{array}$} & \multicolumn{2}{|c|}{$\begin{array}{l}\text { Oranges } \\
\text { Yleld Index }\end{array}$} & \multicolumn{2}{|c|}{$\begin{array}{c}\text { Bananas } \\
\text { Yield Index }\end{array}$} & \multicolumn{2}{|c|}{$\begin{array}{l}\text { Rice } \\
\text { Yield Index }\end{array}$} & \multicolumn{2}{|c|}{$\begin{array}{l}\text { Corn } \\
\text { Yield Index }\end{array}$} & \multicolumn{2}{|c|}{$\begin{array}{l}\text { Wheat } \\
\text { Yield Index }\end{array}$} & \multicolumn{2}{|c|}{$\begin{array}{c}\text { Feijāo } \\
\text { yield Index }\end{array}$} \\
\hline & 296 & 74 & 402 & 106 & 78,100 & 98 & 1,479 & 109 & 1,638 & 110 & 1,286 & 110 & 816 & 96 & 690 & 99 \\
\hline 1951 & 416 & 104 & 394 & 104 & 80,183 & 100 & 1,465 & 108 & 1,617 & 109 & 1,309 & 112 & 584 & 69 & 692 & 100 \\
\hline 1952 & 399 & 99 & 399 & 105 & 80,007 & 100 & 1,441 & 105 & 1,565 & 106 & 1,214 & 104 & 852 & 101 & 626 & 90 \\
\hline 1953 & 402 & 100 & 380 & 100 & 80,337 & 100 & 1,356 & 100 & 1,482 & 100 & 1,169 & 100 & 848 & 100 & 695 & 100 \\
\hline 1954 & 462 & 115 & 345 & 91 & 83,876 & 105 & 1,403 & 103 & 1,388 & 93 & 1,228 & 105 & 806 & 95 & 702 & 101 \\
\hline 1955 & 429 & 107 & 419 & 111 & 83,636 & 105 & 1,313 & 92 & 1,488 & 100 & 1,190 & 102 & 921 & 109 & 662 & 95 \\
\hline 1956 & 429 & 107 & 287 & 76 & 80,864 & 101 & 1,385 & 102 & 1,366 & 92 & 1,167 & 100 & 965 & 114 & 611 & 88 \\
\hline 1957 & 426 & 106 & 384 & 101 & 82,499 & 103 & 1,420 & 105 & 1,635 & 110 & 1,274 & 109 & 677 & 80 & 681 & 98 \\
\hline 1958 & 356 & 89 & 416 & 110 & 75,873 & 95 & 1,385 & 102 & 1,523 & 103 & 1,273 & 109 & 407. & $4 B$ & 684 & 98 \\
\hline 1959 & 381 & 94 & 503 & 133 & 75,125 & 94 & 1,400 & 103 & 1,529 & 103 & 1,258 & 108 & 515 & 61 & 651 & 94 \\
\hline 1960 & 347 & 86 & 464 & 122 & 74,481 & 93 & 1,389 & 102 & 1,617 & 109 & 1,298 & 111 & 625 & 74 & 676 & 97 \\
\hline 1961 & 329 & 82 & 500 & 132 & 74,180 & 93 & 1,401 & 103 & 1,699 & 115 & 1,312 & 112 & 533 & 63 & 676 & 97 \\
\hline 1962 & 302 & 75 & 483 & 127 & 73,552 & 92 & 1,441 & 106 & 1,659 & 112 & 1,305 & 112 & 949 & 112 & 620 & 89 \\
\hline 1963 & 306 & 76 & 379 & 100 & 75,916 & 95 & 1,415 & 104 & 1,542 & 104 & 1,315 & 113 & 494 & 58 & 651 & 94 \\
\hline 1964 & 315 & 76 & 277 & 73 & 71,455 & 89 & 1,485 & 107 & 1,522 & 103 & 1,160 & 99 & 877 & 103 & 623 & 90 \\
\hline 1965 & 333 & 03 & 499 & 131 & 76,054 & 95 & 1,463 & 108 & 1,641 & 111 & 1,381 & 118 & 764 & 90 & 700 & 101 \\
\hline 1966 & 374 & 93 & 376 & 99 & 71,157 & 89 & 1,424 & 105 & 1,449 & 98 & 1,307 & 112 & 857 & 101 & 646 & 93 \\
\hline
\end{tabular}




\begin{tabular}{|c|c|c|c|c|c|c|c|c|c|c|c|c|c|c|c|c|}
\hline Year & \multicolumn{2}{|c|}{$\begin{array}{l}\text { Potatoes } \\
\text { Yield Index }\end{array}$} & \multicolumn{2}{|c|}{$\begin{array}{l}\text { Mandioca } \\
\text { Yield Index }\end{array}$} & \multicolumn{2}{|c|}{$\begin{array}{l}\text { Cotton } \\
\text { Yield Index }\end{array}$} & \multicolumn{2}{|c|}{$\begin{array}{l}\text { Peanuts } \\
\text { Yield Index }\end{array}$} & \multicolumn{2}{|c|}{$\begin{array}{l}\text { Sugarcane } \\
\text { Yield Index }\end{array}$} & \multicolumn{2}{|c|}{$\begin{array}{l}\text { Tobacco } \\
\text { Yield Index }\end{array}$} & \multicolumn{2}{|c|}{$\begin{array}{l}\text { Ontons } \\
\text { Yield Index }\end{array}$} & \multicolumn{2}{|c|}{$\begin{array}{l}\text { Tomatoes } \\
\text { Yield Index }\end{array}$} \\
\hline 1950 & 4,786 & 96 & 13,089 & 103 & 443 & 103 & 927 & 87 & $39,44 \mathrm{~B}$ & 102 & 760 & 97 & 5,294 & 105 & 10,032 & 90 \\
\hline 1951 & 4,827 & 97 & 12,358 & 98 & 400 & 93 & 1,069 & 100 & 38,489 & 100 & 738 & 94 & 4,598 & 92 & 10,145 & 91 \\
\hline 1952 & 4,837 & 97 & 12,616 & 100 & 496 & 116 & 1,028 & 96 & 39,185 & 101 & 689 & 88 & 4,862 & 97 & 10,343 & 93 \\
\hline 1953 & 4,997 & 100 & 12,658 & 100 & 429 & 100 & 1,068 & 100 & 38,690 & 100 & 786 & 100 & 5,040 & 100 & 11,169 & 100 \\
\hline 1954 & 4,931 & 99 & 13,153 & 104 & 469 & 109 & 1,206 & 113 & 39,227 & 102 & 799 & 101 & 4,679 & 93 & 11,283 & 101 \\
\hline 1955 & 5,029 & 101 & 12,934 & 102 & 490 & 114 & 1,118 & 105 & 38,164 & 99 & 756 & 96 & 4,850 & 97 & 9,855 & 88 \\
\hline 1956 & 5,413 & 108 & 13,000 & 103 & 448 & 104 & 1,107 & 104 & 39,121 & 101 & 799 & 101 & 5,369 & 107 & 11,829 & 99 \\
\hline 1957 & $5 ; 269$ & 105 & 12,940 & 102 & 425 & 99 & 1,131 & 106 & 40,688 & 105 & 782 & 99 & 4,906 & 98 & 11,832 & 106 \\
\hline 1958 & 5,296 & 106 & 12,525 & 99 & 423 & 99 & 1,352 & 127 & 41,403 & 107 & 794 & 101 & 4,657 & 93 & 12,516 & 112 \\
\hline 1959 & 5,454 & 109 & 13,374 & 106 & 510 & 119 & 1,400 & 131 & 41,448 & 107 & 793 & 101 & 4,986 & 99 & 12,709 & 114 \\
\hline 1960 & 5,598 & 112 & 13,121 & 104 & 549 & $12 B$ & 1,403 & 131 & 42,485 & 110 & 757 & 96 & 5,100 & 101 & 13,747 & 123 \\
\hline 1961 & 5,649 & 113 & 13,073 & 103 & 565 & 132 & 1,339 & 125 & 43,448 & 113 & 737 & 94 & 4,713 & 94 & 13,332 & 119 \\
\hline 1962 & 5,779 & 116 & 13,442 & 106 & 550 & 128 & 1,282 & 120 & 42,639 & 110 & 805 & 102 & 5,225 & 104 & 14,059 & 126 \\
\hline 1963 & 5,845 & 117 & 13,752 & 109 & 551 & 128 & 1,428 & 134 & 42,228 & 109 & 825 & 105 & 4,762 & 95 & 13,706 & 123 \\
\hline 1964 & 6,056 & 121 & 14,194 & 112 & 472 & 110 & 1,093 & 102 & 43,698 & 113 & 840 & 107 & 5,085 & 101 & 14,368 & 129 \\
\hline 1965 & 6,160 & 123 & 14,282 & 113 & 496 & 116 & 1,374 & 129 & 44,486 & 115 & 906 & 115 & 4,825 & 96 & 14,625 & 131 \\
\hline 1966 & 6,667 & 133 & 13,884 & 110 & 479 & 112 & 1,391 & 130 & 46,339 & 120 & 862 & 110 & 4,503 & 89 & 17.518 & 157 \\
\hline
\end{tabular}

Source: Anuário Estatrstico do Brasil (Rio de Janeiro: IGBE, selected issues). 
TABLE 78

Yield Changes of Selected Crops, 1952-1954, 1960-1962, 1964-1966

\begin{tabular}{|c|c|c|c|c|}
\hline $\begin{array}{c}\text { Relative } \\
\text { Economic } \\
\text { Importance } \\
(1960-1962)\end{array}$ & Product & $1952-1954$ & $1960-1962$ & $1964-1966$ \\
\hline $\begin{array}{r}10 \\
1\end{array}$ & $\begin{array}{l}\text { Cocoa } \\
\text { Coffee }\end{array}$ & $\begin{array}{r}105 \\
99\end{array}$ & $\begin{array}{r}81 \\
127\end{array}$ & $\begin{array}{r}85 \\
100\end{array}$ \\
\hline 12 & Oranges & 102 & 93 & 92 \\
\hline 9 & Bananas & 103 & 104 & 107 \\
\hline 2 & Rice & 100 & 112 & 104 \\
\hline 3 & Corn & 103 & 112 & 110 \\
\hline 8 & Wheat & 99 & 83 & 100 \\
\hline \multirow[t]{2}{*}{5} & Edible beans & & & \\
\hline & (feijão) & 97 & 94 & 93 \\
\hline 11 & Potatoes & 99 & 114 & 126 \\
\hline 7 & Mandioca & 101 & 104 & 111 \\
\hline 4 & Cotton & 108 & 129 & 112 \\
\hline 16 & Peanuts & 103 & 125 & 120 \\
\hline 6 & Sugarcane & 101 & 111 & 116 \\
\hline 13 & Tobacco & 96 & 97 & 110 \\
\hline 14 & Onions & 97 & 100 & 102 \\
\hline 15 & Tomatoes & 98 & 123 & 134 \\
\hline
\end{tabular}

Source: Computed from Table 77. 
the increase seems to have been restricted to this period. Sugarcane also experienced an increase, as did tobacco. The latter crop also had the yield increases only in recent years.

The sources of these increases in yields vary a great deal from product to product. Cotton has benefited from new higher-yield varieties, developed by the Campinas Experiment Station, which increased basic yields some 74 percent in the period from 1948 to 1953 to the present. This improved seed was distributed through a state seed monopoly, which also treated the seed to control disease. As the seed was distributed, an intensive program to improve cultivation practices was also carried out. 12 The results have indeed been significant, and clearly show what an intensive program to raise the level of. technology can do.

A somewhat similar program was undertaken with coffee, through the introduction of Novo Mundo, an exceptionally high-yield variety. The implantation of new varieties of tree crops is more difficult, however, because of the fixed-asset nature of the original plantings and the length of time necessary to reap the benefits. The increase in yield of coffee was probably as much due to the relatively great shift in production from the lower-yield areas of Minas Gerais, Rio de Janeiro, and even São Paulo, to the higher-yield soils of Parana.

The reason for the decline in yields of coffee in recent years is not clear. It may be due to the natural decline in the fertility of the soils, as well as to the aging of the trees. Apparently, the introduction of the higher-yield Novo Mundo has not been sufficiently rapid to counterbalance these other factors.

The increases in yields for tomatoes, potatoes, and peanuts probably reflect a concentration of production on more fertile soils and the increased use of modern inputs such as fertilizer, pesticides, and insecticides. It is interesting to note that these three products are highly commercialized and have had relatively large increases in their demand. This appears to have affected the price ratios in such a way as to make the use of the modern inputs profitable. 
The increase in the yield of sugarcane has been due in large part to the shift in location of production, although there has been some breeding work done on sugarcane, and the use of fertilizer has increased over time. The major factor, however, is probably the shift in production to the fertile soils of São Paulo.

The remaining products, some of which are quite important economically, have experienced declines in yields or have had no change. The most serious decline has occurred with cocoa, at one time an important export earner. As time has passed, however, the plantings have grown old and have declined in productivity. Little or no effort was made until recently either to renovate the plantings or to modernize the technology of the region.

The yield of wheat also declined substantially, despite some fairly intensive efforts to develop disease-resistant varieties. It appears to have recuperated in recent years, however. The yield of edible beans has declined, as has the yield of oranges .

In summary, then, the average yield in the aggregate of the major agricultural products has not increased in the postwar period. Moreover, it is important to recognize that these aggregate data mask a very important characteristic of Brazilian agriculture. Although it is not documented here, it is generally the case that yields tend to decline in the old, traditional areas of production while new, higher-yield areas are coming into production. To a certain extent these tend to counterbalance each other.

The aggregate data also mask some other aspects of the yield situation. For example, it is interesting to note that fairly large differentials in yields among states have been maintained for fairly long periods of time. In addition, it is important to recognize that the geographic centers of production for a number of important crops have shifted greatly over time. This is a dynamic aspect of Brazilian agriculture that has not been brought out adequately in the previous analysis. 
As a final point, it should be noted that yields in Brazil for most crops are much lower than they are in other parts of the world. Data on a select group of crops are presented in Table 79, with comparisons with major producing countries of the world.

Such data should be interpreted with care. It is clear that a country with the abundant supply of land that Brazil has will not be obtaining the same yields as countries in which land is more scarce. The substitution of the relatively inexpensive land for other inputs would tend to make yields per unit of land low. However, the comparison does indicate the potential for raising yields and the role that Brazil could play as a major food supplier to the world. Moreover, increasing yields will help in raising labor productivity and, in turn, the real returns to labor.

\section{Livestock Productivity}

The situation with respect to the livestock sector is no better, and perhaps is worse than that in the crop sector. Neither the size of the cattle herd nor the productivity has kept up with the growing population and rising incomes. Over a long time period, 1939 to 1959, the production of beef increased in exactly the same proportion as the population. In 1948, there was approximately one cow per inhabitant. This ratio has since declined substantially.

One of the basic problems in the cattle sector is the very low slaughter-herd ratio. In the postwar period this has varied from a low of 9.5 percent in 1955 to a high of 12.3 percent in 1949. (The deficiencies in the data on the livestock sector should be recalled. The slaughter-herd ratio is especially sensitive to inaccuracies since it is a ratio of two variables, both of which may be measured with a sizable error.) This ratio is as high as 19 percent in Argentina and 28 percent in the United States.

Another important aspect of the problem is the low carcass yield per animal slaughtered. The average carcass weight was $164 \mathrm{~kg}$. in the period 19551959, wheras it was $207 \mathrm{~kg}$. in Argentina and $249 \mathrm{~kg}$. in the United States. 
TABLE 79

Comparative Yields of Selected Crops,

Brazil and other countries

(kg. per hectare)

\begin{tabular}{|c|c|c|c|c|c|}
\hline \multirow{3}{*}{$\begin{array}{l}\text { Product } \\
\text { Corn }\end{array}$} & \multirow{3}{*}{$\begin{array}{c}\text { São Paulo } \\
\text { Av. } \begin{array}{c}1960 / 1962 \\
1,488\end{array}\end{array}$} & \multicolumn{2}{|l|}{ Brazil } & \multicolumn{2}{|c|}{ Other Countries } \\
\hline & & Av. $1960 / 19$ & & & \\
\hline & & $\begin{array}{l}\text { Brazil } \\
\text { Rio G. do Sul } \\
\text { M. Gerais } \\
\text { Paraná }\end{array}$ & $\begin{array}{l}1,300 \\
1,340 \\
1,380 \\
1,530\end{array}$ & $\begin{array}{l}\text { Mexico } \\
\text { U.S.A. } \\
\text { Yugosiavia } \\
\text { Argentina } \\
\text { South Africa }\end{array}$ & $\begin{array}{r}900 \\
3,660 \\
2,100 \\
1,830 \\
1,370\end{array}$ \\
\hline $\begin{array}{l}\text { Rice } \\
\text { (unpolished) }\end{array}$ & 1,195 & $\begin{array}{l}\text { Brazil } \\
\text { Rio G. do sul } \\
\text { Goiás } \\
\text { M. Gerais }\end{array}$ & $\begin{array}{l}1,660 \\
2,830 \\
1,660 \\
1,570\end{array}$ & $\begin{array}{l}\text { U.S.A. } \\
\text { Italy } \\
\text { Japan } \\
\text { India }\end{array}$ & $\begin{array}{l}3,830 \\
5,250 \\
4,780 \\
1,520\end{array}$ \\
\hline Potatoes & 10,509 & $\begin{array}{l}\text { Brazil } \\
\text { Rio G. do sul } \\
\text { Paraná }\end{array}$ & $\begin{array}{l}5,620 \\
4,600 \\
5,000\end{array}$ & $\begin{array}{l}\text { U.S.A. } \\
\text { West Germany } \\
\text { Argentina }\end{array}$ & $\begin{array}{r}21,340 \\
22,800 \\
9,240\end{array}$ \\
\hline Tomatoes & 28,938 & $\begin{array}{l}\text { Brazil } \\
\text { Pernambuco } \\
\text { R. de Janeiro }\end{array}$ & $\begin{array}{r}13,540 \\
9,460 \\
15,850\end{array}$ & U.S.A. & $20,600^{\mathrm{a}}$ \\
\hline
\end{tabular}

(continued) 
TABLE 79 (continued)

\begin{tabular}{|c|c|c|c|c|c|}
\hline \multirow[b]{2}{*}{ Product } & são Paulo & \multicolumn{2}{|l|}{ Brazil } & \multirow[t]{2}{*}{ other } & \multirow[t]{2}{*}{ Countries } \\
\hline & Av. $1960 / 1962$ & Av. $1960 / 1$ & & & \\
\hline Peanuts (in hull) & 1,151 & & & $\begin{array}{l}\text { U.S.A. } \\
\text { India } \\
\text { Senegal }\end{array}$ & $\begin{array}{r}1,390 \\
730 \\
950\end{array}$ \\
\hline Sugarcane & 52,170 & $\begin{array}{l}\text { Brazil } \\
\text { Pernambuco } \\
\text { R. de Janeiro }\end{array}$ & $\begin{array}{l}42,970 \\
40,500 \\
41,940\end{array}$ & $\begin{array}{l}\text { U.S.A. } \\
\text { Cuba } \\
\text { Hawai i }\end{array}$ & $\begin{array}{r}50,400^{a} \\
40,320^{a} \\
188,200^{a}\end{array}$ \\
\hline cotton & 996 & $\begin{array}{l}\text { Brazil } \\
\text { Parana }\end{array}$ & $\begin{array}{r}620 \\
1,150\end{array}$ & $\begin{array}{l}\text { U.S.A. } \\
\text { Mexico } \\
\text { India }\end{array}$ & $\begin{array}{r}1,370 \\
1,440 \\
350\end{array}$ \\
\hline
\end{tabular}

average of 1959-1960.

Source: Agricultura em São Paulo, X, 5-6, (May-June, 1963); original data, SEP (Servíço de Estatística dà Prodüção) and publications of FAO and USDA. 


\section{Productivity in Four Important} Milksheds

\begin{tabular}{lccc}
\hline \multicolumn{1}{c}{ Milkshed } & $\begin{array}{c}\text { Production } \\
\text { per Cow } \\
(\mathbf{k g . )}\end{array}$ & $\begin{array}{c}\text { Period of } \\
\text { Lactation } \\
\text { (days) }\end{array}$ & $\begin{array}{c}\text { Daily } \\
\text { Average } \\
\text { per Cow } \\
(\mathrm{kg.})\end{array}$ \\
\hline Rio de Janeiro & 780 & 240 & 3.25 \\
São Paulo & 732 & 240 & 3.05 \\
Belo Horizonte & 446 & 190 & 3.35 \\
Niter6i & 594 & 220 & 2.70 \\
Average & 718 & 235 & 3.05 \\
\hline
\end{tabular}

Source: Rio de Janeiro, Cooperativa Central dos produtores de Leite (CCPL).

Other aspects of the low productivity of the Brazilian cattle industry are the long period of time before slaughter and the low fertility rates. The average age at slaughter varies from four years in the South to more than six years in the Northeast. In other countries the animals are typically slaughtered at 2.5 to 3.0 years of age.

Although fertility data are not available for the entire country, an estimate made in Minas Gerais, the principal cattle state, indicated a fertility rate of 50 percent, with a mortality rate of 20 percent up to the age of 18 months. Hence, from 100 cows, the farmer would, on the average, have only 40 calves reach that age.

The productivity in the dairy sector is also quite low. The results of a survey made in four important milksheds are summarized in Table 80. By almost any standards the production per day is quite low, reflecting the very extensive system of milk production and the low level of technology used in dairy production. The fertility rate is also low; and the mortality rate and disease and insect infestation rates are high.

The productivity in the hog sector is similar. The slaughter-herd ratio is 16.0 to 16.5 percent, 
with an average carcass yield of $61 \mathrm{~kg}$. The average age at slaughter is relatively high, in many states being around 15 months.

Hog production, with a few exceptions in the South, does not tend to be undertaken in large commercial operations. Rather, each farmer tends to have his own few hogs, and they are fed offal from other products and household excesses. The disease incidence is quite high, as is the infestation of parasites. Little or no attempt is made to control these, or to conduct a program of preventive medicine.

Poultry production is tending to become more highly commercialized, and in the process a higher level of technology is beginning to be used. The total impact of this is not yet great, although the changes are taking place rapidly.

\section{Some Aggregate Productivity Anaiyses}

Aggregate data on labor productivity and related factors are presented in Table 81 . Between 1940 and 1960 the production of the agricultural sector increased in constant value terms from $C r \$ 79.3$ billion to Cr\$146.3 billion, or 84 percent. During the same period the number of hectares utilized increased 40 percent, going from 107 million to 150 million. The people employed in agricultural activities increased 20 percent, going from 10.6 million to 12.7 million. (These data are not consistent with those appearing elsewhere because of different definitions of the labor force. However, they are consistent within the table.)

Much of the increase in total production from 1940 to 1950 came about as a result of the increase in hectares in production. Total production increased 20 percent, while hectares in production increased 18 percent. Production per hectare increased only 1 percent in this interval, but production per person increased 13 percent. This appears to be due in part to the increase in land.per capita (land increased 18 percent while persons employed increased only 7 percent), and to make some contribution to the increased output. 
TABLE 81

Production, Number of Hectares, Number of Persons Employed in Agriculture, and

Productivity, 1940, 1950, and 1960

\begin{tabular}{ccccccc}
\hline Year & $\begin{array}{c}\text { Total } \\
\text { Production } \\
\text { (NCr\$) }\end{array}$ & $\begin{array}{c}\text { Hectares } \\
\text { in } \\
\text { Production }\end{array}$ & $\begin{array}{c}\text { Persons } \\
\text { Employed }\end{array}$ & $\begin{array}{c}\text { Hectares } \\
\text { per } \\
\text { Person }\end{array}$ & $\begin{array}{c}\text { Production } \\
\text { per } \\
\text { Hectare } \\
\text { (NCr\$) }\end{array}$ & $\begin{array}{c}\text { Production } \\
\text { per } \\
\text { Person } \\
\text { (NCr\$) }\end{array}$ \\
\hline 1940 & 79.3 & 107.0 & 10.6 & 10.1 & .741 & .748 \\
1950 & 95.2 & 126.7 & 11.3 & 11.2 & .751 & .842 \\
1960 & 146.3 & 150.0 & $12.7^{\text {d }}$ & 11.8 & .975 & 1.152 \\
\hline
\end{tabular}

aillion NCr\$, 1953.

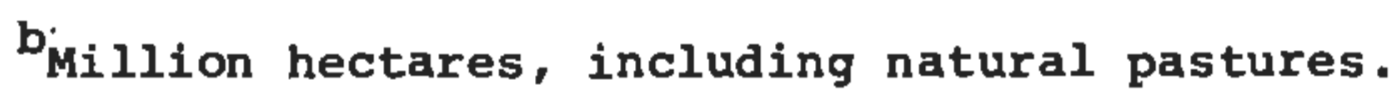

CMillions.

dPreliminary estimate.

Source: IBGE; FGV. 
During the decade from 1950 to 1960 , however, productivity in the agricultural sector appeared to increase somewhat more. Production per person increased 36.7 percent and production per hectare increased 30 percent. Total production increased 54 percent, but hectares in production increased only 18 percent and persons employed only 12 percent.

The source of this increased productivity is of interest. A very crude analysis suggests that the major fraction of it comes from a change in product mix, and not from an increase in yields or productivity for the same crop. In other words, it reflects the substitution of high-value crops for low-value crops, or of crops for livestock.

Our estimates suggest that of the 30 percent increase in production per hectare, 20 percent can be accounted for by the shift in relative value of products per hectare. of the remaining 10 percent, 9 percent comes from an increase in productivity, and 1 percent from the interaction of productivity and product-mix shifts. Of the 9 percent increase due to productivity, 6 percent reflects an increase in livestock production per hectare, and 3 percent an increase in crop production per hectare. Distributed over a 10-year period, these increases in productivity are, of course, quite low.

The increase in labor productivity probably is due in large part to the same considerations, although a similar analysis was not made. Land per person also increased, which can account for some of the increased labor productivity.

If a similar aggregative analysis were made, the results would vary a great deal from one region to another. For example, Ettoril3 has shown that changes in factor productivity in the state of são Paulo during the decade of the 1950's were broadly similar to those experienced in the United States in the same period. Changes such as these in this important agricultural state suggest that factor productivity may have actually declined in other areas, given the relatively small changes in the national aggregates. 
NOTES

1. For basic information on soils, climatic conditions, and the geographic distribution of agricultural production, see zoneamento Agrícola e Pecuário do Brasil, Especies Económicas nos Diferentes Regioes (Rio de Janeiro: Escritorio de Pesquisa Economica Aplicada (EPEA), Ministério do planejamento e Coordinacão Económica, 1966).

2. For details on the recent colonization of the central interior, see Paul Mandell, "Agricultural Development in the Southern Goiss Region" (Unpublished Ph.D. thesis, Columbia University, 1968).

3. Charles A. Krug, "Summary Appraisal of Potential Increases in Agricultural Production" (Exclusively based on technical factors) (unpublished special report prepared for the CIDA study).

4. See A. Estrutura Agrária Brasileira, (Rio de Janeiro; Instituto Brasileiro de Reforma Ágrária (IBRA), 1968).

5. See CIDA Report, p. 83, for the original nomenclature.

6. William H. Nicholls, and Ruy M. Paiva, Ninety-Nine Fazendas: The structure and Productivity of Brazilian Agriculture, 1963, prelim. ed. (Nashville, Tenn.). Four Chapters of a projected seven have been published to date.

7. See Montague Yudelman, Agricultural Development in Latin America: Current Status and Prospects, Twashington, D.C.: Inter-American Development Bank, 1966), p. 60 .

8. Brazil has been manufacturing tractors since 1960. Total output in the 1960-1968 period was 64,023 units, with an annual production in recent years of approximately 12,000 units. The total stock of tractors in Brazil in 1967 has been estimated at 82,000 units. See "Motomecanização da Agricultura" Escritório de Pesquisa Econômica Aplicada, Mínistry of Planning, 1967 (mimeographed), and "Notícias do Sindicato" (No. 116), Sindicato Naciónal da Indastria de Tratores, Caminhöes, Autombveis e Velculos Similares, São Paulo, 1969 (mimeographed). 
9. See, for example, Maria Ignez Angeli Schuh, "A Adocão de Nova Tecnologia na Agricultura, Município de Campinas, 1963-1964" (unpublished Master's thesis, Instituto de Economfa Rural, Rural University of Minas Gerais (UREMG), 1967).

10. The most extensive documentation of the low level of use of modern inputs is in Ruy $M$. Paiva and William H. Nicholls, "Estagio do Desenvolvimento Técnico do Agricultura Brasileira," Revista Brasileira de Economfa (September, 1965), 27-63.

11. The data below are taken from Estudo TecnicoEconômico sóbire a Exeqüibilidade de Aumento na Fabricacão e Uso de Fertilizantes, Calcário e Sáis Minerais no Brasil, report pregented to the Ministry of Agriculture and the. Division of Agriculture and Rural Development, USAID/Brazil, 1964.

12. For more details, see Maria Ignez Angeli Schuh, op. cit.

13. Oscar J. T. Ettori, "Productividade Flsica da Agricultura em. São Paulo," Agricultura em São Paulo, XI, 7 (JulY, 1964), 3-4 $\overline{8}$. 


$\begin{array}{ll}\text { CHAPTER } & \begin{array}{l}\text { THE EDUCATIONAL } \\ \text { AND RESEARCH } \\ \text { INFRASTRUCTURE } \\ \text { FOR AGRICULTURE }\end{array}\end{array}$

Empirical research has shown that education and research can be major factors in raising the level of productivity in the agricultural sector of a country's economy. I This has been shown most clearly in the case of the United States, where a major fraction of the increase in agricultural output in the postwar period is explained not by increases in the use of conventional inputs, but by changes in the quality of inputs (especially labor) and by expenditures on research, 2 The contribution of research has been shown most specifically by the high rates of return on successful innovations-over 700 percent on hybrid corn in the United States--and the high rates of return on investments in education. 3

For these reasons we assess the educational and research infrastructure that is available to service Brazilian agriculture. The analysis concentrates on education, research, extension, the integration of the three, and the availability of economic research institutions to provide a basis for rational economic policy.

THE EDUCATION SYSTEM

As a country, Brazil has not fully recognized the contribution that education or improvements in the quality of its people can make to attaining a more rapid rate of economio growth. Deficiencies exist both in the level of investment in its people and in the kind of education provided. Relatively greater emphasis has been given to law, medicine, and the letters, and relatively less to science and 
technology. The level of educational attainment has been quite low in the total society; but even more, there has been a serious imbalance between the rural and urban sectors, with rural people coming off much the worse.

General Aspects of the Educational Situation

Formal education in Brazil has been strongly influenced by European traditions. Historically it has had a heavy professional orientation, with little emphasis on technology, science, or the preparation of students for a modern industrial society. This emphasis has shifted a great deal in recent years, but the traditions of the past are quite strong even today.

The structure of the formal school system is as follows:

$\begin{array}{lll}\text { 1. Escola primário } & - & 5 \text { years } \\ \text { 2. Ginásio } & - & 4 \text { years } \\ \text { 3. Colégio } & - & 3 \text { years } \\ \text { 4. Superior school } & - & 4 \text { or } 5 \text { years }\end{array}$

This system is by no means uniform. In some areas, primary schools may cover either four or six years, with corresponding adjustments in the upper levels.

This structure of formal education has historically been the route for entering the universities. At the level of the colégio, however, there are vocational schools which have prepared students for work experience, rather than for the university. These vocational schools are basically of three types: commercial schools, normal schools, and agro-technico schools. Although at one time they offered only terminal programs, their graduates can now enter a university if they can pass the extrance examination.

Schooling is by no means universal in Brazil, although four years of primary school is obligatory by law, starting at seven years of age. Education is provided primarily through a public school system, 
although private and parochial schools exist at all levels. From the ginásio level on through the superior schools, admittance is gained through entrance examinations. Since the number of potential entrants is generally much greater than the number of vacancies, competition is generally very keen, and the vestibular is a traumatic experience in the lives of many Brazilian children. At the university level, many schools have one-year courses specifically to prepare students for writing the entrance examinations. In some cases these are repeated two and three times by the more persistent students.

The lack of qualified teachers at all levels is a serious problem in Brazil. The teachers for the primary level in general come from the normal schools - which are secondary schools in the level of training provided. Teachers for the ginásios and colégios are supposed to be trained by the philosophy faculties, but this in general is not the case. There have not been enough graduates to meet the need, nor have teachers' salaries been sufficiently high to attract graduates to the profession. As a result, it has been estimated that up to 90 percent of the teachers at this level are lawyers, doctors, and other professional people who have passed a licensing examination and teach part-time.

Primary schooling is provided free by the government in those areas where schools are available. Secondary schooling, however, is usually very expensive for the student, with the result that in general only the upper-income classes are able to continue their schooling. At the university level, however, education tends to be free. Tuition, housing, board, and books are provided free, or for only a small charge. However, attempts have been made in recent years to have university students bear more of their educational costs.

Brazil has been making progress in providing increased educational opportunities. However, much remains to be done, especially in rural areas. The rapid rate of growth of the population makes the magnitude of the educational problem especially great.

General school matriculation in the postwar period is presented in Table 82. Prior to 1965, enrollment gradually increased at all levels, with the exception of graduate training. 
TABLE 82

General School Matriculation, a 1947-1965

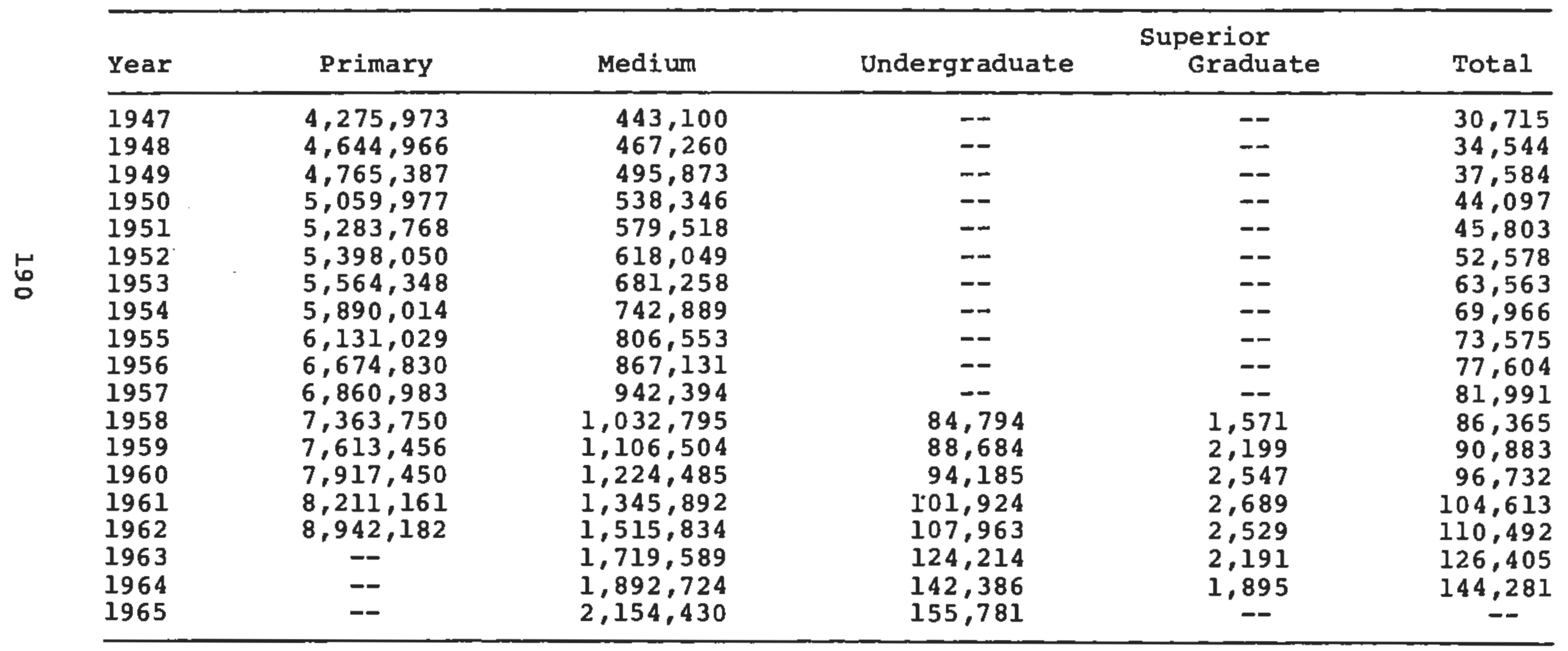

${ }^{a}$ General matriculation is that registered up to the end of the first semester. ção e cultura. 
Percent of Students Ages 7-14

Enrolled in School, a by Region, 1964

\begin{tabular}{|c|c|c|c|}
\hline Region & Total & Urban $^{b}$ & Rural $^{c}$ \\
\hline & \multicolumn{3}{|c|}{$\begin{array}{l}\text { Percent of Students } \\
\text { Ages } 7-11 \text { Enrolled in School }\end{array}$} \\
\hline Brazil & 66.2 & 81.3 & 51.5 \\
\hline \multirow[t]{2}{*}{$\begin{array}{l}\text { North } \\
\text { Northeast } \\
\text { East } \\
\text { South } \\
\text { Central West }\end{array}$} & $\begin{array}{l}69.7 \\
52.6 \\
65.6 \\
73.8 \\
71.5\end{array}$ & $\begin{array}{l}87.6 \\
78.5 \\
79.5 \\
83.4 \\
78.2\end{array}$ & $\begin{array}{l}54.1 \\
37.3 \\
48.1 \\
64.6 \\
51.1\end{array}$ \\
\hline & \multicolumn{3}{|c|}{$\begin{array}{l}\text { Percent of Students } \\
\text { Ages } 12-14 \text { Enrolled in School }\end{array}$} \\
\hline Brazil & 66.5 & 81.0 & 51.4 \\
\hline $\begin{array}{l}\text { North } \\
\text { Northeast } \\
\text { East } \\
\text { South } \\
\text { Central West }\end{array}$ & $\begin{array}{l}74.1 \\
57.7 \\
67.8 \\
69.3 \\
77.7\end{array}$ & $\begin{array}{l}90.6 \\
81.7 \\
80.6 \\
79.9 \\
83.6\end{array}$ & $\begin{array}{l}58.4 \\
42.3 \\
50.8 \\
58.1 \\
56.4\end{array}$ \\
\hline
\end{tabular}

${ }^{a}$ students enrolled in school are defined as those who study in primary or medium schools or courses, public or private, or receive at home education equivalent to that in the schools, given by a capable person, with continuity and observance of pre-established hours.

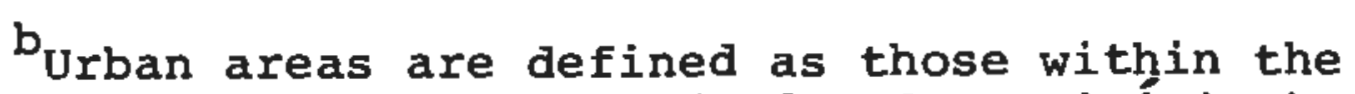
legal limits of the cities (sedes de municipios) and of the suburbs (sedes de outros distritos do municipio).

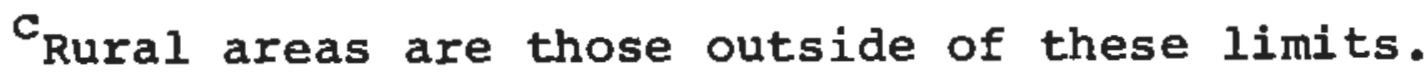
Source: Censo Escolar do Brasil, Resultados Preliminares, I, II. 
The macnitude of the task still remaining can be seen in Table 83 , which presents information on the percent of the age groups $7-11$ and 12-14 who were attending school in 1964. The data indicate that only two-thirds of the students of these age groups were enrolled in school at that time. (It seems rather implausible that the percent of students enrolled in the 12-14 age group would be greater than that in the 7-11 age group, for one would have thought that dropouts would have lowered this percentage. Two factors appear to explain the anomalies of the table. First, the data reflect the rather late age at which children start school in Brazil. Second, there is evidence that there was considerable short-counting of the population, with the missions concentrated among those not in school. This latter bias in the data causes the enrollment rates presented in the table to be on the high side. The points made in the text would therefore not be altered, although the problems may be even more serious than the data indicate. Moreover, there is a significant difference between the urban and rural population, with the rural population having a much lower rate of schooling than the urban population. The magnitude of the problem can be seen in the case of the Northeast, where only 37 percent of the rural age group 7-11 are enrolled in schools. The difference in the quality of schooling between rural and urban areas makes the discrepancy between the two sectors even greater.

The data also show a very sizable variation among regions in the rate of school enrollment. This regional variation tends to be greater for the rural population; and if data on a state basis were provided, the variation would be even greater.

Data with similar detail were not available for medium (secondary) schooling. However, Table 84 provides estimates of the index of medium schooling in 1950 and 1960. Although enrollment in medium schools more than doubled from 1950 to 1960 , this raised the percent of the age group in school from only 6.6 percent to 11.2 percent. And though data are not available to show it, it is generally recognized that the bulk of medium schooling is provided in urban areas. Rural people either do not have secondary schools available, or they have to travel to the urban centers to obtain it. 
TABLE 84

Index of Medium

Schooling, 1950 and 1960

\begin{tabular}{lrr}
\hline & \multicolumn{1}{c}{1950} & \multicolumn{1}{c}{1960} \\
\hline $\begin{array}{l}\text { Population Age } \\
\text { 12-18 }\end{array}$ & $8,166,155$ & $10,959,667$ \\
Enrolled in School & 538,346 & $1,224,485$ \\
Index of Schooling & 6.68 & 11.28 \\
\hline
\end{tabular}

Source: SEEC.

Table 85 shows that the index of schooling drops even further at the university level. In 1960 only a little over 1 percent of the population 19-25 years of age was attending college.

\section{TABLE 85}

Index of Superior

Schooling, 1950 and 1960

\begin{tabular}{lrr}
\hline & 1950 & \multicolumn{1}{c}{1960} \\
\hline $\begin{array}{l}\text { Population Age } \\
\text { 19-25 }\end{array}$ & $7,069,782$ & $8,667,792$ \\
School Population \\
(B.S. and beyond) & 44,097 & 96,732 \\
Index of Schooling & 0,528 & 1.118 \\
\hline
\end{tabular}

Source: SEEC.

In addition, only a very small fraction of the students were studying agriculture and veterinary medicine. 
Enrollment in Higher Educational Institutions, by Field, 1960

\begin{tabular}{|c|c|c|}
\hline Field & Enrollment & $\begin{array}{l}\text { Percent } \\
\text { of Total }\end{array}$ \\
\hline Agriculture & 2,738 & 2.9 \\
\hline Arts & 2,813 & 3.1 \\
\hline $\begin{array}{l}\text { Economic Sciences, } \\
\text { Administration }\end{array}$ & 8,838 & 9.5 \\
\hline $\begin{array}{l}\text { Engineering, Architecture, } \\
\text { Related Fields }\end{array}$ & 12,569 & 13.5 \\
\hline Law & 23,322 & 25.0 \\
\hline Medicine, Related Fields & 19.372 & 20.8 \\
\hline $\begin{array}{l}\text { Philosophy, Sciences, } \\
\text { Letters, Education }\end{array}$ & 21,533 & 23.1 \\
\hline $\begin{array}{l}\text { Statistics, Library Train- } \\
\text { ing, Museum Training, } \\
\text { Domestic Arts }\end{array}$ & 708 & 0.7 \\
\hline Total & 93,182 & 100.0 \\
\hline
\end{tabular}

Source: H. R. พ. Benjamin, Higher Education in the American Republics (New York: McGraw-Hill, 1965). 
The deficiency of trained people for the agricultural sector can be seen by recognizing that over 50 percent of the population are still working in agriculture, and that agriculture is a principal component of the gross national product. Although enrollment in superior schools of agriculture has increased significantly since 1960 , Brazil is still a long way from having the cadre of trained people necessary to develop a modern agriculture.

The rate of expenditures on education is as important as the number of people receiving schooling, since it indicates the rate at which the country is investing in its people. Although recent data are not available, Table 87 provides some information on the expenditures for the five-year period 19591963.

These data are corrected for changes in the price level, and hence show the expenditures in real terms. Perhaps the most striking point is the sizable increase from 1959 to $1961-20$ percent--and then the decline that had taken place by 1963. Despite the fact that expenditures in current terms were increasing rapidly, inflation was increasing still faster; and thus the expenditure in real terms declined.

When it is recognized that the population was increasing rapidly during this period, especially the population of school-age children, it becomes clear that the per capita expenditure on education during this period was declining significantly. This, of course, is a quite serious matter.

Although this expenditure in absolute terms is interesting in its own right, it gives little or no indication of the relative size of the effort being put forth. This can perhaps best be seen by relating educational expenditures to the internal national product. Such data are provided in Table 88. They tell a story similar to that provided by the expenditure data. Educational expenditures as a percent of national internal product increased from 1959 to 1961. However, from 1961 to 1963, they declined almost to their 1959 level, despite the sizable increase in current-value expenditures on education. 
TABLE 87

National Expenditures for Education,

by Level, 1959-1963

(1960 Cr\$)

\begin{tabular}{|c|c|c|c|c|c|c|c|c|}
\hline Year & Primary & $\begin{array}{l}\text { Billion } \\
\text { secondary }\end{array}$ & $\begin{array}{l}\text { Cr\$ } \\
\text { Higher }\end{array}$ & Total & Primary & $\begin{array}{l}\text { Percent of } \\
\text { Secondary }\end{array}$ & $\begin{array}{l}\text { Total } \\
\text { Higher }\end{array}$ & Total \\
\hline 1959 & 20.01 & 17.63 & 10.89 & 48.53 & 41.2 & 36.4 & 22.4 & 100.0 \\
\hline 1960 & 22.98 & 17.06 & 9.99 & 50.03 & 45.9 & 34.1 & 20.0 & 100.0 \\
\hline 1961 & 30.83 & 16.06 & 11.36 & 58.25 & 52.9 & 27.6 & 19.5 & 100.0 \\
\hline 1962 & 30.66 & 17.57 & 11.06 & 59.29 & 51.7 & 29.6 & 18.7 & 100.0 \\
\hline 1963 & 26.23 & 16.56 & 11.86 & 54.65 & 48.0 & 30.3 & 21.7 & 100.0 \\
\hline
\end{tabular}


TABLE 88

Education Expenditures as a Percentage

of the Internal National

Product, 1959-1963

(billion Cr\$)

\begin{tabular}{llcc}
\hline Year & $\begin{array}{l}\text { Internal } \\
\text { National } \\
\text { Product }\end{array}$ & $\begin{array}{c}\text { Education } \\
\text { Expenditures }\end{array}$ & Percentage \\
\hline 1959 & 1761.60 & 41.85 & 2.38 \\
1960 & 2363.60 & 63.90 & 2.70 \\
1961 & 3522.00 & 100.50 & 2.85 \\
1962 & 5586.80 & 147.90 & 2.83 \\
1963 & 9847.00 & 239.05 & 2.43 \\
\hline
\end{tabular}

This relatively low level of expenditure is cause for serious concern. At various international meetings, such as those at Punta del Este, Uruguay, Santiago, Chile, and Addis Ababa, Ethiopia, the recomnendation has been made that the Latin American and Afro-Asian countries make an effort to apply financial resources to education in an amount equivalent to 4 percent of the national product. As Table 88 indicates, Brazil was far from attaining this figure. Although precise data are not available, it is not likely that the situation changed in the period through 1968. The stringent containment policy of the period 1964-1968 led to cuts in federal expenditures in almost all activities. There is some evidence in early 1969, however, that the government is going to give more attention to education.

Further data on the problem are provided in Table 89, which shows the number of students per thousand inhabitants for selected South American countries in 1964. Of those countries shown, Brazil has the lowest rate in primary schooling and superior schooling, and the second lowest level in medium schooling. 
TABLE 89

Students per Thousand Inhabitants, Selected South American

Countries, 1964

\begin{tabular}{lccc}
\hline Country & $\begin{array}{c}\text { Primary } \\
\text { Schooling }\end{array}$ & $\begin{array}{c}\text { Medium } \\
\text { Schooling }\end{array}$ & $\begin{array}{c}\text { Superior } \\
\text { Schooling }\end{array}$ \\
\hline Brazil & 113 & 21 & 1.4 \\
Venezuela & 165 & 29 & 4.4 \\
Argentina & 137 & 30 & 9.0 \\
Colombia & 132 & 21 & 2.1 \\
Ecuador & 142 & 19 & 2.4 \\
\hline
\end{tabular}

Source: SEEC.

Although data are not available on per capita expenditures for the rural and urban populations, some insight into this relationship can be gained from the estimates of per capita expenditures by states. (See Table 90.) Since some states tend to be more agricultural than others, the information by states provides some notion of the relative expenditures on the rural and urban populace.

These data illustrate the tremendous variation, on a per capita basis, of the expenditures on education among the various states. One notes, of course, that the highly urbanized states of Guanabara and são Paulo are far above the other states, closely followed by Rio Grande do Sul, which is also relatively urbanized. The low-income, agricultural states are investing much less in their people. And it is most likely that if data were available on expenditures in rural and urban areas, the discrepancy would be greater than that suggested by the data presented.

Perhaps the most striking evidence of the difference in educational achievement between the rural and urban areas is an estimate by the organization of American States (OAS) that over two-thirds of the literate persons in Brazil live in urban areas. Given 
TABLE 90

Per Capita Expenditures on Education, by state, 1959-1961

\begin{tabular}{|c|c|c|c|}
\hline State & $\begin{array}{l}\text { Federal } \\
\text { Expendi- } \\
\text { tures per } \\
\text { Capita } \\
\text { (Cr\$) }\end{array}$ & $\begin{array}{l}\text { State and } \\
\text { Municipal } \\
\text { Expendi- } \\
\text { tures per } \\
\text { Capita } \\
\text { (Cr\$) }\end{array}$ & $\begin{array}{l}\text { Total } \\
\text { Expendi- } \\
\text { tures per } \\
\text { Capita } \\
\text { (Cr\$) }\end{array}$ \\
\hline Amazona & 101 & 442 & 543 \\
\hline Pará & 382 & 350 & 732 \\
\hline Maranhão & 43 & 71 & 114 \\
\hline Piauf & 52 & 110 & 162 \\
\hline Ceará & 280 & 236 & 516 \\
\hline $\begin{array}{l}\text { Rio Grande do } \\
\text { Norte }\end{array}$ & 190 & 214 & 404 \\
\hline Paraíba & 149 & 234 & 383 \\
\hline Pernambuco & 380 & 124 & 504 \\
\hline Alagoas & 156 & 242 & 398 \\
\hline Sergipe & 104 & 208 & 312 \\
\hline Bahia & 208 & 261 & 469 \\
\hline Minas Gerais & 202 & 604 & 806 \\
\hline Espírito Santo & 193 & 666 & 859 \\
\hline Rio de Janeiro & 111 & 673 & 784 \\
\hline Guanabara & 5,658 & 478 & 6,137 \\
\hline São Paulo & 28 & 2,481 & 2,508 \\
\hline Parana & 246 & 740 & 986 \\
\hline Santa Catarina & 89 & 652 & 740 \\
\hline Rio Grande do sul & 354 & 1,717 & 2,072 \\
\hline Mato Grosso & 56 & 370 & 426 \\
\hline Goiás & 112 & 427 & 538 \\
\hline
\end{tabular}

Source: Aspectos da Inflação Brasileira e Suas Perspectivas para 1965, "Estudos ANPES," No . 1 TRio de Janeiro: Associaçăo Nacional de Programação Econ6mica e Social (ANPES), 1965). 
the natural tendency of literate people to migrate to urban areas in search of better employment, this probably overstates the difference in educational opportunities available. The discrepancy is quite suggestive, however.

\section{Higher-Level Agricultural Training}

In 1968 Brazil had 16 agricultural colleges and 12 schools of veterinary medicine. Most of these colleges are located in the South Central region, and principally along the extensive coastal belt. They vary a great deal in their source of support and in their academic organization. Most of them depend on federal funds, with support until recently coming from either the Ministry of Agriculture or the Ministry of Education and Culture. (In 1967 all colleges of agriculture that were previously under the Ministry of Agriculture were transferred to the Ministry of Education.) Two of the colleges-The Rural University of Minas Gerais at Viçosa and the Superior School of Agriculture "Luiz" de Queiroz" at Piracicaba, São Paulo--receive the major fraction of their support from state funds, although the former is being transferred to federal support. And, until recently, the Superior School of Agriculture at Lavras, Minas Gerais, was supported by private funds. (Formerly supported by the Presbyterian Church, this school was transferred to federal support several years ago and was made a part of the Federal University of Minas Gerais, which is located in Belo Horizonte. The School of Agriculture remained in Lavras, however.) Organizationally, they vary from autonomous schools, with little or no relation to supporting schools or disciplines, to highly integrated schools in which basic disciplines are taken in other schools of a reasonably modern, well-integrated university.

In 1968 the agricultural colleges had more than 5,000 students enrolled and were graduating about 1,000 agronomos. Compared with 1964 , these figures represent an increase of more than 35 percent in enrollment and almost 100 percent in graduates.

With a couple of notable exceptions, Brazilian schools of agronomy and veterinary medicine have not kept up with modern educational trends. They have been plagued with a European-type catedratico (chair 
professor) system, part-time staff, part-time students, and a rigid curriculum that has not kept up with changing conditions and involves many courses and heavy classroom attendance. Little time is left for the student to pursue independent work.

Course work tends to be almost exclusively theoretical, with little or no practical content. This problem is compounded by the fact that the majority of the students come from the cities, and have little experience with the problems and needs of agriculture.

The teacher-student ratio is quite high $(1: 4)$ compared with most countries (United States 1:30; England, 1:12; Germany, 1:15). But the curricula offer little contact with the problems of contemporary rural Brazil, and the professors in general are not highly trained. The large fraction of parttime teaching reduces the incentive for teachers to develop their own skills and knowledge.

The development of an educational system consisting of part-time faculty, part-time students, and night schools is a response to economic conditions. The low value placed on education by the society leads to low faculty salaries. The opportunity costs of education for the student are quite high. The part-time system, on the part of both the faculty and the students, thus makes for effective use of resources, given the relevant costs and returns. It induces many trained people, who would not otherwise do so, to provide teaching services and facilitates the matriculation of many students who would not otherwise be able to attend school.

On the other hand, the multiple job holding in many cases results in a less than satisfactory job of teaching because of the divided effort. In addition, the dependence on part-time faculties severely limits the development of university-based research .

Data on the number of graduate engineeragronomos and veterinarians are presented in Table 91. In the early $1940^{\prime} \mathrm{s}$, graduates of these two types of schools made up as much as 7.8 percent of total university graduates. The percentage declined after that and has remained relatively low until the 
TABLE 91

Graduates of Schools of Agronomy and Veterinary Medicine, 1940-1964

\begin{tabular}{|c|c|c|c|c|}
\hline Year & $\begin{array}{c}\text { Schools of } \\
\text { Agronomy }\end{array}$ & $\begin{array}{c}\text { Schools of } \\
\text { Veterinary } \\
\text { Medicine }\end{array}$ & $\begin{array}{l}\text { Total } \\
\text { of (1) } \\
\text { and (2) }\end{array}$ & $\begin{array}{l}\text { Percent of } \\
\text { Total Higher- } \\
\text { Level Graduates }\end{array}$ \\
\hline $\begin{array}{l}1940 \\
1941 \\
1942 \\
1943 \\
1944 \\
1945 \\
1946 \\
1947 \\
1948 \\
1949 \\
1950 \\
1951 \\
1952 \\
1953 \\
1954 \\
1955 \\
1956 \\
1957 \\
1958 \\
1959\end{array}$ & $\begin{array}{l}260 \\
141 \\
143 \\
198 \\
188 \\
179 \\
194 \\
228 \\
267 \\
229 \\
171 \\
237 \\
266 \\
233 \\
190 \\
274 \\
250 \\
236 \\
325 \\
300\end{array}$ & $\begin{array}{r}89 \\
58 \\
78 \\
79 \\
38 \\
54 \\
36 \\
57 \\
92 \\
55 \\
61 \\
63 \\
85 \\
114 \\
119 \\
146 \\
128 \\
162 \\
163 \\
140\end{array}$ & $\begin{array}{l}349 \\
199 \\
221 \\
277 \\
226 \\
233 \\
230 \\
285 \\
359 \\
284 \\
232 \\
300 \\
351 \\
347 \\
309 \\
420 \\
378 \\
398 \\
488 \\
440\end{array}$ & $\begin{array}{l}7.80 \\
4.90 \\
5.71 \\
6.14 \\
4.16 \\
3.51 \\
3.66 \\
4.66 \\
4.10 \\
3.68 \\
2.78 \\
3.31 \\
3.64 \\
3.07 \\
2.65 \\
3.08 \\
2.65 \\
2.66 \\
3.24 \\
2.70\end{array}$ \\
\hline
\end{tabular}




\begin{tabular}{|c|c|c|c|c|}
\hline Year & $\begin{array}{l}\text { Schools of } \\
\text { Agronomy }\end{array}$ & $\begin{array}{l}\text { Schools of } \\
\text { Veterinary } \\
\text { Medicine }\end{array}$ & $\begin{array}{l}\text { Total } \\
\text { of (1) } \\
\text { and (2) }\end{array}$ & $\begin{array}{l}\text { Percent of } \\
\text { Total Higher- } \\
\text { Level Graduates }\end{array}$ \\
\hline $\begin{array}{l}1960 \\
1961 \\
1962 \\
1963 \\
1964\end{array}$ & $\begin{array}{l}335 \\
410 \\
394 \\
474 \\
548\end{array}$ & $\begin{array}{l}139 \\
176 \\
144 \\
160 \\
187\end{array}$ & $\begin{array}{l}474 \\
586 \\
538 \\
634 \\
735\end{array}$ & $\begin{array}{c}2.88 \\
3.21 \\
2.92 \\
3.35 \\
--\end{array}$ \\
\hline $\begin{array}{l}\text { Total } \\
\text { (1940- } \\
1963)\end{array}$ & 6,122 & 2,436 & 8,558 & 3.40 \\
\hline
\end{tabular}


present. In recent years the training of engineeragr6nomos has increased substantially, especially in the period since 1961. As a fraction of total university training, however, this has probably not increased, since total university enrollment has been increasing also.

Data on graduate-level training are extremely limited. However, the first graduate program in agriculture (aside from the European-style doctorates) was started at Viçosa in 1961. By the end of 1965 , a total of 56 master's degrees had been awarded, with 30 in agricultural economics, 21 in plant science, and five in animal science. As of April 30, 1966, a total of 265 students had received graduate training at the UREMG.

The program at Viçosa has tended to stabilize in size since 1966, and is turning out a good flow of M.S.-level trained technicians. By early 1969 there had been some 120 candidates awarded degrees, with approximately 70 of these in agricultural economics.

Other schools have recently established graduate programs. The school of agriculture at Piracicaba in São Paulo started an ambitious program in 1965. The Federal University in P6rto Alegre has had a small program since the early $1960^{\prime} \mathrm{s}$, with most emphasis being given to agricultural economics and soils. The National school of Agriculture at $\mathrm{Km}$. 47, Rio de Janeiro, is trying to start a graduate program, but lacks the resources to develop a quality program.

Although the program at Piracicaba has been large and ambitious, it has not been in effect long enough to make the same contribution to the provision of higher-level trained manpower as that at viçosa. The program at Pôrto Alegre has been considerably smaller in scope and size than either the vicosa or Piracicaba programs. It does appear to be well institutionalized, however.

Prior to the establishment of these programs, most advanced training was obtained either in the United States or Europe. (The European-type doctorate programs which most schools offered were largely independent-study programs and consisted for the most part of the preparation of a thesis. In general 
they involved little or no formal course work.) The number of students going abroad was extremely small, however, and under less than ideal conditions. The difficulty of obtaining leave for more than one year resulted in students' doing graduate work, but not obtaining the formal degree. The consequences of this were an extremely limited amount of research training and research experience on the part of the trainee, and a very small number of people with either the M.S. or Ph.D.

An overview of the 12 schools of agronomy that were in existence in 1961 is presented in Table 93. since that time, four new schools have been added: one in the state of Goiss, located at Goisnia; one in the state of Rio Grande do Sul, at Santa Maria; a second school in Bahia; and a second school in são Paulo. The schools at Goiania and Santa Maria are federal schools and are supported through the Ministry of Education and culture.

An important aspect of this table is the extent to which the schools operated with excess capacity. The situation was somewhat improved in 1961 , and since that time has improved still further. Both the capacity and the enroliment in most schools have grown substantially in the 1961-1966 period. (Compare with Table 92. )

\section{Agricultural Colleges}

In the North American summer of 1966, visits were made by the authors to the colleges of agriculture and veterinary medicine. On these visits data were collected on staffing, level of training, programs, and other factors which permit a brief description and evaluation of the schools. In the present section the highlights from that survey are presented. Although by no means a complete picture of the respective schools, the information presented does give some indication of the general quality of the schools and the scope of their programs.

\section{Escola de Agronomía da Amazônia (Belém, Pará)}

This is the only school of agronomy in the North, and it is located on the grounds of the Institute of Agricultural Research and Experimentation of the North (IPEAN), the federal research center. 
TABLE 92

Location, Year of Establishment, and Enrollment of Colleges of Agriculture, 1964-1967

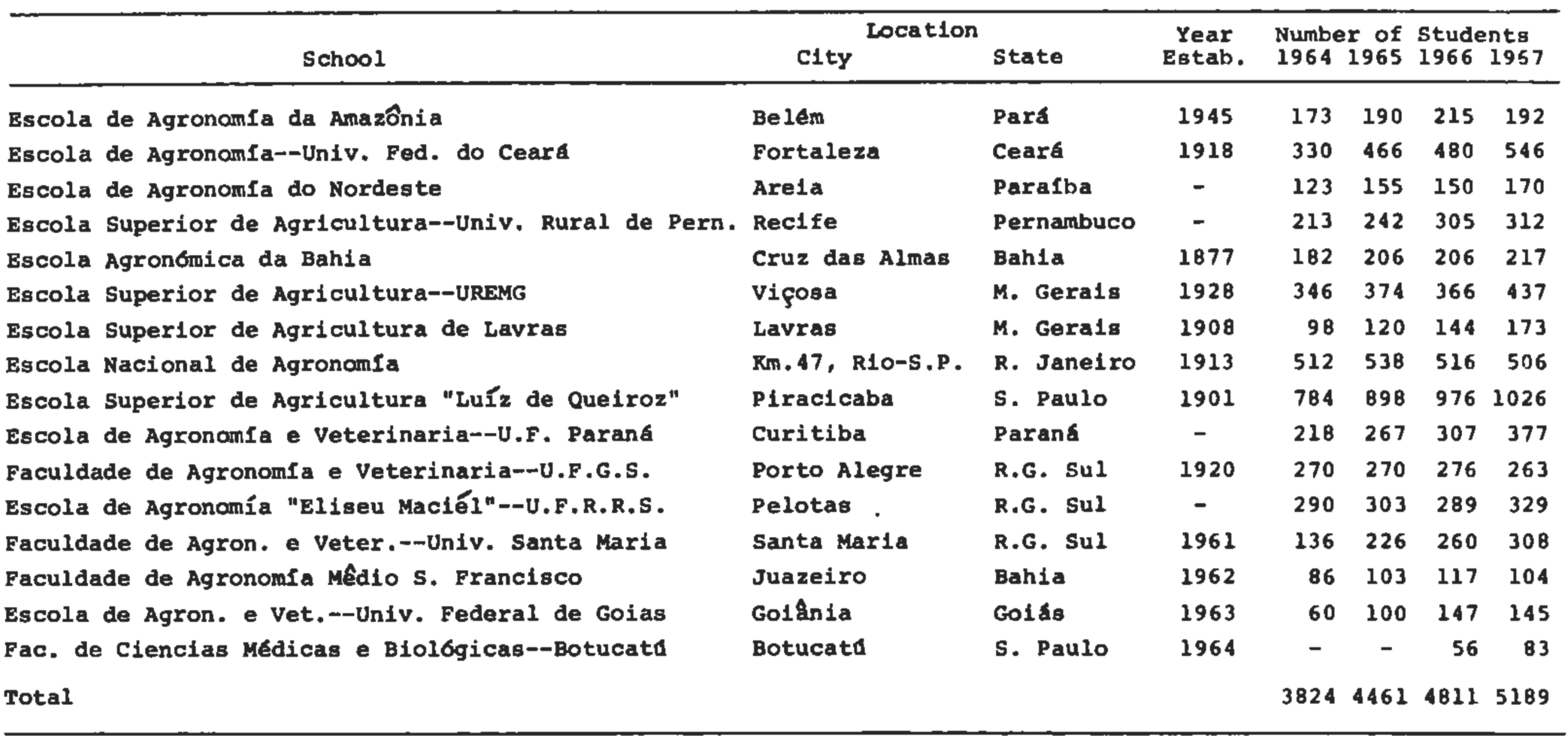

Source: Victor Pellegrini and Lawrence $w$. Witt, "Appraisal of Graduate Programg in Agricultural Econoinics and the Effectiveness of the Graduates, In the Institutional setting of Brazil, Mexico and Peru." (East Lansing, Mich.: Department of Agriculturai Economica, Michigan state University). (Mimeographed.) 
Schools of Agronomy, 1958 and 1961

\begin{tabular}{|c|c|c|c|c|c|c|}
\hline Location & $\begin{array}{l}\text { Adminis- } \\
\text { tration }\end{array}$ & $\begin{array}{c}\text { Full-time } \\
\text { Teachers and } \\
\text { Instructors } \\
1959\end{array}$ & $\begin{array}{l}\text { Total } \\
\text { Capacity }\end{array}$ & $\begin{array}{l}\text { Studentg } \\
\text { Number } \\
\text { Enrolled } \\
1958\end{array}$ & $\begin{array}{c}\text { Number } \\
\text { Enrolled } \\
1961\end{array}$ & $\begin{array}{c}\text { Proposed } \\
\text { Budget } 1959^{a} \\
\text { (thousand } \mathrm{Cr} \$)^{b}\end{array}$ \\
\hline $\begin{array}{l}\text { North } \\
\text { Belém }\end{array}$ & Federal & 20 & 200 & 52 & 94 & 21,000 \\
\hline $\begin{array}{l}\text { Northeast } \\
\text { Fortaleza } \\
\text { Areia } \\
\text { Recife }\end{array}$ & $\begin{array}{l}\text { Federal } \\
\text { Federal } \\
\text { Federal }\end{array}$ & $\begin{array}{l}43 \\
31 \\
42\end{array}$ & $\begin{array}{l}240 \\
160 \\
160\end{array}$ & $\begin{array}{r}157 \\
83 \\
124\end{array}$ & $\begin{array}{r}217 \\
78 \\
105\end{array}$ & $\begin{array}{l}76,242 \\
36,497 \\
15,949\end{array}$ \\
\hline $\begin{array}{l}\text { East } \\
\text { Cruz das Almas } \\
\text { Viçosa } \\
\text { Lavras } \\
\text { Km. } 47\end{array}$ & $\begin{array}{l}\text { State } \\
\text { State } \\
\text { Private } \\
\text { Federal }\end{array}$ & $\begin{array}{l}20 \\
42 \\
17 \\
56\end{array}$ & $\begin{array}{l}200 \\
308 \\
160 \\
200\end{array}$ & $\begin{array}{r}100 \\
208 \\
93 \\
225\end{array}$ & $\begin{array}{l}122 \\
400 \\
236\end{array}$ & $\begin{array}{r}21,844 \\
42,680 \\
3,215 \\
53,359\end{array}$ \\
\hline $\begin{array}{l}\text { South } \\
\text { Piracicaba } \\
\text { Curitiba } \\
\text { PGrto Alegre } \\
\text { Pelotas }\end{array}$ & $\begin{array}{l}\text { State } \\
\text { Federal } \\
\text { Federal } \\
\text { Federal }\end{array}$ & $\begin{array}{l}84 \\
58 \\
40 \\
32 \\
\end{array}$ & $\begin{array}{l}400 \\
200 \\
200 \\
160 \\
\end{array}$ & $\begin{array}{r}328 \\
105 \\
201 \\
91 \\
\end{array}$ & $\begin{array}{l}399 \\
127 \\
387\end{array}$ & $\begin{array}{l}91,798 \\
12,484 \\
15,765 \\
25,212 \\
\end{array}$ \\
\hline Total & & 485 & 2,588 & 1,767 & 2,165 & 416,045 \\
\hline
\end{tabular}

a obtained by an ABCAR questionnaire.

${ }^{b}$ Cr\$1 = US\$0.0049 (1959).

c Since federalized.

Source: CIDA, Inventory of Information Basic to the Planning of Agricultural Development in Latin America. 
A large building with facilities for 200 students was completed in 1958. Until recent years enrollment has been low, however.

The school was created in 1945 by IPEAN, with the idea that the IPEAN staff could teach in the school. It did not begin to function until 1951, however. In 1959 the school separated from IPEAN, although it remained connected with the Ministry of Agriculture until its recent transfer to the Ministry of Education. It is an autonomous school, and has no connection with a university.

Enrollment had grown from a total of 30 students in 1960 to 215 in 1966 . Most of the students come from the state of Amazonas.

The staff of 49 were all on part-time employment. Their salaries ranged from Cr\$225,000 per month for instructors to $\operatorname{Cr} \$ 405,000$ per month for catedraticos (minimum wage in the region was cr\$61,000 per month). Twenty of the staff were catedraticos, although not by concurso (examination). Of the remainder, 11 were assistant professors and 18 were instructors. Only two of the staff had studied abroad, and only one had an M.S.

The school itself did little research, although some of its staff worked part-time in IPEAN. It did little or no extension work, al though it recently had added two instructors in extension. In general, the contact with both research and extension organizations was quite limited. The school has had little or no impact on the region except as it trains engineer-agronomos.

Escola de Agronomía, Universidade Federal do Ceará (Fortaleza, Ceará)

This is one of three schools of agronomy in the Northeast. Its support comes from the Ministry of Education and culture, and it is well integrated into one of the more dynamic, modern universities in Brazil. Basic courses in the agricultural program are taken in the other schools of the university, uniform entrance examinations are held, and the student has to repeat only the course he fails--not the entire academic year--if he should not pass a given subject. These are significant departure's from the usual pattern in Brazil. 
of the total staff of 75,42 were employed fulltime. Salaries ranged from Cr\$284,000 per month (plus 75 percent for full-time) for teaching assistants to Cr\$405,000 per month (plus 100 percent for full-timel for catedraticos. None of the staff had either an M.S. Or a Ph.D. However, three were studying in the United States at the time of the visit, and one more was to leave soon. It was planned to send five to $s i x$ professors to the United states for additional training, with additional staff to be sent to the three Brazilian institutions offering graduate training.

The maximum number of students it could handle per class was 140 . At the time of the visit it had a total enrollment of 480. Enrollment was growing rapidly and had practically doubled since 1961.

The school maintained a great number of convenios, or contracts, with other agencies. Perhaps its largest was with USAID and the University of Arizona, which provided from 9 to 11 North American professors to work in the school on teaching and research. In addition, it had convenios with suDENE (the co-ordinating agency for development of the Northeast) and the Ministry of Agriculture for research on cotton, with the Banco do Nordeste for research on the economics of milk production, with sUDENE for scholarships and for equipment for providing training in mechanics, with SUDENE for research in food crops, and with ETA (a federal organization concerned with technical assistance programs) for the creation of a training center to provide short courses for the upgrading of technicians in the state.

The school was making a concerted effort to start a research program. It was providing some training in extension and was beginning to do some extension itself. Its relations with the state extension agency (ANCAR-Ceara) appeared to be quite good, and it recognized the need to gain more empirical knowledge of the state's agriculture and rural people. There appeared to be no strong research centers in the state, so there was little or no opportunity to establish contacts with such centers.

If this school continues to receive strong financial support and strong leadership, it can develop into a strong agricultural school for the Northeast. The university of. Which it is a part has 
a relatively modern structure. The good relations with the extension agency, the development of a research program, and the upgrading of its staff give it the potential for having considerable impact on the state and region.

Escola de Agronomía do Nordeste (Areia, Paraiba)

This is the second of the three schools of agronomy in the Northeast. It is an autonomous school and has no connections to a supporting university. Its financial support is federal; and until the recent transfer to the Ministry of Education, it was supported by the Ministry of Agriculture.

Only three of its staff of 37 were employed full-time. None of them had an M.S. or Ph.D., and only two had studied abroad. One of these did graduate work at Chapingo, Mexico, and the other studied extension at the IICA Center in uruguay. Of the remainder, 16 had served internships at other institutions in Brazil, with a heavy concentration of work at Piracicaba, são Paulo.

The school both maintained an agricultural colêgio and provided university-level training. Enrollment in both programs had grown rapidly since 1960 , with the university-level enrollment increasing from 78 in 1960 to 150 in 1966 . Even so, the enrollment was still not up to capacity, in large part because of the lack of qualified students.

The school did no research and no extension. It did hold some Farmers' Weeks for the training of rural leaders, however. An unusual part of the program was the maintenance of training centers in home economics in 17 municipios of the state. These were one-year courses involving training in sewing, cooking, small industries, agricultural practices, and hygiene and nursing. Enrollment in these training programs was approximately 400 per year, although it had been as high as 518 in 1961 .

Escola Superior de Agricultura, Universidade Rural de Pernambuco (Recife, Pernambuco)

This school is part of a rural university (combined with a school of veterinary medicine) and received its financial support from the Ministry of Agriculture until the recent transfer. 
None of its 51 professional staff was employed full-time. With a few rare exceptions, the staff had had no regular courses at the graduate level. some of them had served short internships (estágios) in other institutions, however.

Enrollment had tripled since 1960, going from 110 in that year to 305 in 1966. The school has good physical facilities and is located in a good-size city.

No research was conducted within the school, nor did it have an extension program. Its only objective was to train engineer-agrónomos. Its contact with both extension and research agencies was limited, although some of its staff worked part-time in other research institutions, such as the near-by Federal Institute (IPEANE). Its contact with rural people appeared to be practically non-existent.

Escola Agron8mica do Bahia

(Cruz das Almas, Bahia)

This school was established by the Emperor of Braxil, Dom Pedro II, in 1877, and is the oldest agricultural school in the country. It has been administered by the Bahia state government since 1904, and until recently was one of the three remaining state-supported schools of agronomy. (In 1968 it was federalized and made part of the Federal University of Bahia in Salvador.) It is located in a small, isolated community; and despite its capacity, enrollment has been low because of a lack of living accommodations.

Unfortunately, the state was not providing the necessary financial support for the school at the time of the visit. Both its program and its staff were deteriorating, and there was a real question as to how long it could continue to exist. suDENE had attempted to help the school, as had CEPLAC.

The staff of 36 were all part-time employees. Their salaries ranged from Cr\$317,000 per month for assistant professors to $\operatorname{Cr} \$ 328,000$ per month for catedraticos. Only a very few of them had studied abroad, and advanced training at other centers within the country was extremely limited. One staff member had an M.S., five had studied in the United states for eight-month periods some 20 years ago, and one 
had studied in Portugal. Around 14 of the staff were soon to retire, and the younger staff had received little or no advanced training.

The capacity at the time of the visit was for up to 400 students, although enrollment at the time was only 206. The graduating class in 1966 numbered 38 .

Escola Superior de Agricultura, Universidade Rural de Minas Gerais (Vicosa, Minas Gerais)

This school is supported by the state government of Minas Gerais. The university is made up of a School of Forestry, a School of Home Economics, and the School of Agriculture. It is unique in Brazil in that it is the only school which holds the U.S. land-grant college philosophy of combining teaching, research, and extension, and which makes a serious attempt to serve the people of the state in ways other than training engineer-agronomos.

The school has received an unusual amount of outside support, with convenios between the USAID and Purdue University and grants of over $\$ 1,000,000$ from the Ford Foundation. The contract with the USAID and Purdue has provided 17 North American professors since 1963 (10 for a five-year period prior to that), plus supporting resources. The Ford grants helped in raising faculty salaries, staff development, and the development of research and extension programs. As a result of the USAID-Purdue contract, a regular graduate program has been developed that grants $M . S$. degrees and generates substantial research.

The School of Agriculture had a faculty of 112 in mid-1966. Of these, there were only 11 catedraticos. The major fraction of the staff consisted of young instructors, who were 54 in number. A few additional, more experienced staff had been contracted as they retired.

Five of the faculty had Ph.D.'s in 1966, and 26 had M.S.'s. An additional six were close to terminating the $\mathrm{Ph} . \mathrm{D}$., and a relatively large number were working on the M.S. The training, especially at the advanced levels, was reasonably weli diversified among top U.S. universities. In addition to 
those who had obtained formal graduate degrees, a few had done graduate work in the United states without obtaining the degree.

The entire staff in the school of Agriculture was employed on a full-time basis. Base salaries ranged from Cr $\$ 570,000$ per month for instructors to Cr\$855,000 per month for catedraticos. Housing was provided for the catedraticos.

The university maintains a relatively large number of convenios in addition to those cited above. Among these are programs with the Rockefeller Foundation, the Ministry of Agriculture, the Agriculture Fund, the Brazilian Institute of coffee (IBC), the National Institute for Agricultural Development (INDA), and special research projects with USAID.

The 1966 graduating class was the largest in the history of the university. The 102 baccalaureate degrees represented about one-tenth of the total graduated since the school began in 1927. Of these, 82 were engineer-agrbnomos-an increase of 193 percent over the graduating class of 1958. The enroliment in the School of Agriculture was 366 .

The School of Home Economics (the first such school in Brazil) graduated 19 with a B.S. in 1966. The university has also established a school for Forestry, and has maintained an agricultural colegio for a number of years.

The undergraduate curriculum has been modernized in recent years, and has considerably less rigidity than that encountered in other schools. Specialization (diversification to the Brazilians) is permitted in the last two years. A viable research service has been developed within the school, although this is not as strong as it might be. Although some staff do research, a major fraction of it is done through graduate students, and an overall plan attempting to respond to the needs of the state is lacking.

An extension service has also been established within the school. It has been organized to complement the existing stage extension service. It consists essentially of a staff of specialists which develops programs for training the local municfpio agent. The school also has an ABCAR training center located on the campus, and plays an important role in training ABCAR staff. 
An extension of the university has been establisted in the Minas Triangle, one of the most productive agricultural regions of the state. Its objective is to conduct research on the problems of that region and to provide an extension program. The university is increasingly being called into consultation on problems of both state and national agricultural policy. Its impact on the nation economy can potentially be great, especially if it continues to develop its research capability.

A very serious problem that the university currently faces is the lack of support from the state government. In many respects the school has grown too fast, especially in view of the rather limited resources of the state government. If it is able to develop a more secure financial base, the university is in a position to play a leadership role among schools of agriculture, not only within Brazil, but in all of Latin America.

\section{Escola Superior de Agricultura de Lavras} (Lavras, Minas Gerais)

This school was founded in 1908 and prior to 1964, when it was federalized, it belonged to the Instituto Gammon, a private educational organization of North American origin affiliated with the Presbyterian Church. The school was federalized by law in 1964, but did not start to function as a federal school until 1965. It is affiliated with the Ministry of Education and culture, and was initially an isolated school. It has since been made part of the Federal University of Minas Gerais in Belo Horizonte.

As a private school it was not possible to develop the physical facilities necessary for an institution of this nature. For this reason the buildings, laboratories, etc. tend to be deficient. For the same reasons it was not possible to develop a strong professional staff consistent with its mission. since the federalization of the school, however, substantial sums have been appropriated for physical facilities. In addition, a strong program of staff development has been undertaken.

There were 33 staff members in 1966 , of whom 23 were employed on a full-time basis. Only one was a catedratico, in part reflecting the decline in the school that had taken place prior to federalization. 
Only one staff member had an M.S., although at least one other had studied abroad. Of the 33 total staff, eight were studying at either Viçosa or Piracicaba for an M.S. Two more being sent to Argentina.

The pay scale was the same as that for other schools belonging to the Ministry of Education. The associate professor rank, which is held by 18 , received Cr $\$ 410,000$ per month, plus 100 percent for full-time employment.

The school had a very interesting project called "Full Dedication." The student worked fulltime and received Cr\$40,000 per month. He could either present a research project--which, if approved, would be carried out under the direction of a professor-or he could work as an assistant on one of the research projects in the school. There were 62 students working in this program at the time of the visit. The capacity of the school was 150-200 students. There were plans to increase this to 1,000 .

The research program was not extensive, although it was being expanded by creation of a department of research. The integration with the state extension agency was reasonably good, although the direct contact of the school with rural areas was quite limited.

Escola Nacional de Agronomía, Universidade (Km. 47, Rio de Janeiro)

This is the national School of Agriculture and was supported by the Ministry of Agriculture until the recent transfer to the Ministry of Education. The other schools that make up the university are a School of Veterinary Medicine, a recently formed Graduate School, a School of Forestry, a School of Technical Education, a School of Industrial Chemistry, and a School of Family Education. The enrollment, as of 1966, was as follows:

1. Veterinary School 260

2. Agronony School 516

3. School of Forestry Engineering

4. School of Technical Education 12

5. School of Industrial Chemistry 100

6. School of Family Education $\frac{21}{910}$ 
7. Graduate School

8. Medium School (ginásio científico e agro-técnico)

The School of Agronomy had 19 chairs, of which five were vacant. Eight new professors had been added in recent years, all at the lower academic levels. These new staff were the only ones who had full-time employment, the remainder of the staff also working either in the nearby research institute (IPEACS) of the Ministry of Agriculture, or in nearby Rio de Janeiro. The remainder of the staff consisted of 38 teaching assistants, making a total of 60 professional staff.

The faculty is reasonably well trained, even though it has been difficult for them to leave the country. (Until recently they had to have permission of the president of the country to leave, because of the role of the school as the national school of Agriculture.) In 1966 they had one $P h . D$. and seven master's degrees from U.S. institutions. In addition, nine staff had studied abroad for a year or two. Five of these had studied in the United states, two in Germany, one in Japan, and one in Sweden. One of the M.S.'s was currently working on a Ph.D. at MIT, and another was ready to go to Davis. There were plans to send two more for M.S. training.

In addition to this training, ten of the staff had received, advanced training in an internal training program that was offered prior to 1961. This program was established specifically to provide training for Ministry personnel, but others were permitted to enter once the course was offered. The duration of the courses was 18 months, with a written report or study presented at the end. The courses were given by professors of the school and visiting professors, including some foreigners.

Enrollment had not grown as rapidly as at some other schools, although the school was operating at what was believed to be capacity. The recent entering class had 86 students accepted, plus nine foreign students. The 86 entrants were selected from among 344 candidates.

The Graduate school started to function in 1966, and is offering an M.S. The enrollment in the agronomy program was 17 , with an additional 20 doing 
graduate work in veterinary medicine. The Graduate School operates without a specific curriculum. The student's program to suit his interest, is developed with a counselor. A thesis is obligatory, as is a foreign language.

Until recently, very little research has been done at the school itself, although the staff have done research at the Ministry's nearby Institute and with other organizations. A little more research is beginning to be done, and the existence of the Graduate school will probably further promote this. The university will probably not do substantial research until the faculty are employed full-time, however.

The university had no extension program of its own, and its connections with existing extension agencies were quite tenuous. The effect of the university on the rural areas of the state appeared to be minimal, except indirectly as it trained agrbnomos.

Escola Superior de Agricultura "Luíz de Queiroz," Universidade de Sao Paulo (Piracicaba, Sao Paulo)

This is one of the two remaining state-supported schools, and makes up part of the University of São Paulo. Financial support of the school has been strong, in part because são paulo is the wealthiest state in the union. The principal program in the school is for training engineer-agronomos, although a graduate school was formed in 1964 and a home economics program was started in 1967.

Enrollment had more than doubled between 1961 and 1966. They had 976 students in the agr6nomo program in 1966. This was the only school of agronomy that went to a five-year program. The fifth year is for diversification, or what North Americans would call specialization, and there are six fields in which this can be done. Graduate work comes after this, although in the graduate school students who were graduated from four-year programs are accepted.

The failure of other colleges and universities of agriculture to go to five-year programs has created some difficulties with the graduate program. It is difficult to integrate students from four-year programs into their curriculum, as well as their own students into other programs. 
The school pays the highest salaries of any agricultural school in the country. All staff were employed full-time, and starting salaries ranged from Cr\$755,840 per month for an instructor to Cr\$1,008,200 per month for a catedratico. For each 10 years of experience there was an increase of 10 percent of the base salary.

There were 171 staff members, with 23 catedraticos. Only four chairs were vacant at the time of the visit. The major portion of the staff had received their undergraduate training at ESALQ. They had a few Ph.D.'s on the staff, and between 50 and 60 percent of the staff had M.S.'s from abroad. Seven additional staff were studying abroad at the time of the visit, with one of these working on a Ph.D.

The rather extensive graduate program offered degrees in eight fields of agriculture. Enrollment in the graduate school in 1966 was 193 . It was expected that 18 months would be required to complete the master's degree, and a thesis was required. Formal curricula were prescribed.

The graduate program was probably started on too ambitious a scale. Some programs were rather weak, although those in genetics and plant breeding and statistics and experimentation were quite strong. The school has a staff that is of high enough quality to develop a viable graduate program, given enough time to work out the problems.

For a long period of time this was the only school of agriculture in Brazil that was doing a substantial amount of research. Research facilities are good, and the staff does research as a basis for receiving their full-time pay. The development of the graduate program is likely to give further stimulus to the research effort.

The faculty and school did a little extension, but in general this was rather limited. They had little or no contact with the regional agronomo (the extension agent in são Paulo) and practically no contact with farm people. There is a discipline of extension and sociology associated with the chair of rural social sciences, but this is comparatively new. Graduate work can be done in this area. 
Two other means of communication were available for the school. One was the "Week of Luiz de Queiroz," held once a year. This was primarily an alumi meeting at which scientific papers were given, and provided one means of communicating research results to agronomos working in the state. In addition, they were developing a divulgation center in the school.

The school has a convenio with the USAID and Ohio State University which provides a staff of 14 visiting professors. In addition, it has convenios with IICA, FAO, the state Secretariat of Agriculture, IBC, the National Research Council, and private firms.

The school also collaborated on a small scale with the secondary schools in the state. They were considering the creation of a school to train professors for secondary agricultural schools.

To summarize, this is one of the top two schools of agriculture in the country, and one of the best in Latin America. Were it to develop an extension program, it would be close to having the land-grant college concept. It has made an important contribution to both the state and the nation, although its contribution could be greater were it more responsive to the needs of rural people.

The state recently created two additional superior schools of agronomy. These were created in very precarious conditions, and it was said that the classes were given at a very low level. Such fragmentation of effort poses a serious threat to an already existing, strong school, since it will undoubtedly siphon off needed resources.

Escola de Agronomía e Veterinaria do Paraná (Curitiba, Paraná)

The agricultural and veterinary courses are different courses within the same school. The school was incorporated into the Federal University of Parana in 1960, and receives its support from the Ministry of Education and Culture. Prior to this it was a private school until 1953, when it was federalized into the Ministry of Agriculture.

The school had 307 students enrolled in both programs in mid-1966. There were 85 professors in 
the school for both courses. Only a few of these had received graduate training, although eight had spent between four and eight months in the United states. They had two staff at Piracicaba working on the M.S. In general there was little incentive or opportunity to gain additional training because of the part-time employment. The other employment complicates leaving for additional training. The entire university has only 10 staff on full-time employment.

The school was doing a limited amount of research, and its staff also worked as researchers in other institutions. Although having only a restricted extension program, it did have good relations with the state extension service. The school also had a convênio with IBC, which was financing some research in the coffee areas of the state.

The university in total has had a philosophy of taking itself out to the people. Until recently this was done by the use of a "rolling university," in which groups of professors were.taken out to municípios to give one-week courses. Enrollment in this program had been quite good, but real difficulties existed because of large class size in some cases, and the tremendous diversity of backgrounds. This program was discontinued in 1965.

Faculdade de Agronomía e Veterinaria, Universidade Federal do Rio Grande do Sul (Pôrto Alegre, Rio Grande do Sul)

This school began in 1920 with a staff composed chiefly of Germans and Italians. Separate facilities exist for veterinary and agronomic work, although both are within the same school. The school is located practically within the city, and is part of the Federal University of Rio Grande do sul. There is little or no sharing of courses, however.

The school is reasonably well equipped in terms of physical facilities for both courses. A major problem is the lack of full-time employment. Of the 103 faculty, only 20 were employed full-time in 1966. The remainder work part-time in the state Secretariat of Agriculture or elsewhere. This has inhibited staff development of a strong program in the school.

The school receives no resources from the state. It has a research farm (experiment station), but it 
is an hour and a half away from the school. The research program is minimal; and what there is, is done largely in the Institute of Forage Research, which is connected with the school.

There were roughly 400 students in the combined school at the time of the visit. Of these, 280-300 were studying agriculture, and the remainder veterinary medicine. Eight students were foreigners.

One member of the staff had a Ph.D. and six had the M.S. Only one man was doing advanced work, although a large group of students was being prepared to go to the United states in 1967.

There was no formal integration with the state extension agency, although they did work together. The extension agency had done much to project the name of the school in rural areas, and there was much talk of making the integration stronger. The integration with the Secretariat of Agriculture was good, in large part because they shared the same staff.

The school had a convenio with the University of wisconsin and USAID. There were seven Americans in residence in mid-1966, and the contract called for 13. This program is planned to continue through 1972.

Graduate programs have been developed in the fields of soils and social sciences. There were nine students in the soils program, and four had finished the graduate program in agricultural economics. This latter program was administered through the Institute of Economic Studies and Research (IEPE).

Escola de Agronomía "Eliseu Maciél" (Pelotas, Rio Grande do SuI)

This is an autonomous school, connected with the Institute of Agricultural Research and Experimentation of the South, and was supported through the Ministry of Agriculture until the recent transfer to the Ministry of Education. Factual knowledge on this school is limited, since it was not possible to talk with anyone on the staff at the time of the visit. However, the faculty were employed only part-time, and most of them worked in the Ministry of Agriculture's Institute (IPEAS) the remainder of the time. Some research was done in the school, but most of the research effort was in the Institute. 
Only one of the staff had an M.S., although the staff that was shared with the Institute had some advanced training. As elsewhere, the problem of multiple job holding complicates the upgrading of staff.

There were approximately 300 students in the school. Since there is no housing on the campus, they have to be transported to and from the nearby city and the school each day.

\section{Other Schools}

Visits were not made to the recently founded schools, so comparable information will not be presented on them.

\section{Placement of Agrónomos}

Recent data are not available on the employment of the graduates from the schools of agronomy. However, most of them go into government employment, in the extension organizations, as'researchers at the research centers, or in the schools of agronomy. With the development of the graduate programs in Brazil, an increasing number are going into graduate work.

\section{Summary}

Brazil has the base for developing a strong system of schools of agriculture that will be capable of training the high-level manpower necessary for modernizing its agricultural sector. The major problems facing the schools are: (1) students who tend to come from the city rather than the farm, and hence know little about farming and do not identify with the rural people; (2) inadequately trained students and/or an entrance examination system which does not function well; (3) part-time staff, which inhibits the development of research within the schools and makes staff development difficult; (4) curricula that are still quite rigid, despite the flexibility now provided by law; (5) inadequte libraries and inadequate literature in Portuguese; (6) lack of a philosophy that the university should be an active agent of change in modern society and involve itself with current problems; and (7) lack of financial support. 
As has been indicated above, there is a tendency to create new schools of agriculture. It is hoped that such proliferation will be resisted. Any increments of resources to this sector should be applied towards strengthening the existing institutions so that they can perform their task better.

At the present time, Brazil has two very good colleges of agriculture--those located at Piracicaba and vicosa. It has four others that rank somewhat below these, but that are making serious efforts to strengthen their staff and programs. If a graduate program is instituted at Fortaleza in 1970, as is now planned, Brazil will have four centers of graduate work in agriculture that are well distributed on a regional basis, and one in veterinary medicine. Resources should be allocated to these schools so that they become centers of excellence, and so that they can serve as a basis for upgrading the staff of the remaining schools.

It is also important that more attention be given to the Central West. At least one strong agricultural college is needed to satisfy the demands of this rapidly growing, important agricultural region.

\section{Veterinary schools}

Less attention was given in our analysis to the veterinary schools. The reason for this was that most of them are primarily teaching institutions, and do little or no research or extension. Three of the veterinary schools are state-supported and nine are federally supported. Sumary data on the eight schools, as of 1958 and 1961 , are presented in Table 94.

Four of the schools are relatively new. One has been formed at the University of Ceard and will soon graduate its first class. The new schools at Santa Maria and Goilinia are combined with schools of agronomy. And veterinary training is also being provided in the Faculdade de Ciencias Medicas e Biologicas at Botucatu, in são Paulo, which is statesupported.

In general the schools of veterinary science are more hindered by lack of resources than are the 
TABLE 94

Schools of Veterinary science, 1958 and 1961

\begin{tabular}{|c|c|c|c|c|c|c|}
\hline \multirow[b]{2}{*}{$\begin{array}{c}\text { Northeast } \\
\text { Recife }\end{array}$} & \multirow{2}{*}{$\begin{array}{l}\text { Adminis- } \\
\text { tration }\end{array}$} & \multirow{2}{*}{$\begin{array}{c}\text { Total } \\
\text { Staff } \\
33\end{array}$} & \multirow{2}{*}{$\begin{array}{c}\begin{array}{l}\text { Student } \\
\text { Capacity }\end{array} \\
200\end{array}$} & \multicolumn{2}{|c|}{$\begin{array}{c}\text { No. } \\
\text { Students } \\
1958 \quad 19.61\end{array}$} & \multirow{2}{*}{$\begin{array}{c}\text { Proposed } \\
\begin{array}{c}\text { Budget, 1959 } \\
\text { (Thousand Cr\$) }\end{array} \\
9,298\end{array}$} \\
\hline & & & & 86 & 61 & \\
\hline $\begin{array}{l}\text { East } \\
\text { Salvador } \\
\text { Belo Horizonte } \\
\text { Km. } 47 \\
\text { Niter } 6 i\end{array}$ & $\begin{array}{l}\text { State } \\
\text { Statea } \\
\text { Federal } \\
\text { Federal }\end{array}$ & $\begin{array}{l}36 \\
33 \\
32 \\
38\end{array}$ & $\begin{array}{l}160 \\
160 \\
200 \\
200\end{array}$ & $\begin{array}{r}66 \\
111 \\
152 \\
137\end{array}$ & $\begin{array}{r}63 \\
121 \\
288\end{array}$ & $\begin{array}{l}19,081 \\
27,300 \\
18,000 \\
18,870\end{array}$ \\
\hline $\begin{array}{l}\text { South } \\
\text { são Paulo } \\
\text { Curitiba } \\
\text { Porto Alegre }\end{array}$ & $\begin{array}{l}\text { State } \\
\text { Federal } \\
\text { Federal }\end{array}$ & $\begin{array}{l}48 \\
-- \\
29 \\
\end{array}$ & $\begin{array}{l}120 \\
120 \\
200 \\
\end{array}$ & $\begin{array}{r}117 \\
43 \\
63 \\
\end{array}$ & $\begin{array}{r}111 \\
73 \\
115 \\
\end{array}$ & $\begin{array}{l}35,560 \\
12,484 \\
15,765 \\
\end{array}$ \\
\hline & & 249 & 1,360 & 775 & 833 & 156,358 \\
\hline
\end{tabular}

${ }^{\text {a }}$ since federalized.

Source: J. Pinto Lima et al., Técnicos para o Desenvolvimento da Agricultura (Rio de Janeiro: ABCAR, 1961). 
schools of agronomy. Research in this field is quite expensive, since it requires specialized equipment and large investments in animals. Moreover, the staff training requirements are high. For these reasons there has not been much research in veterinary medicine, and little attack has been made on the problems of tropical livestock production.

The best school of veterinary science in Brazil is the Escola de Veterinaria do Universidade Federal de Minas Gerais, located at Belo Horizonte. The school was originally part of the Rural University of Minas Gerais at Vicosa, but moved to Belo Horizonte and became part of the Federal University. Its support comes from the Ministry of Education and culture. It accepts 50 new students each year.

This school is quite strong, and some have said that it is the best of its kind in Latin America. Two of its staff had the Ph.D. and 16 had the M.S. in 1966. Additional staff were abroad doing graduate work, with some working on the Ph.D.

The faculty has recently instituted a graduate program. This program has considerable potential for upgrading the staffs of the other faculties of veterinary medicine, although the problem of obtaining research support will still remain.

The school at Belo Horizonte does some research, but its budget for this is quite small. It is attempting to develop an extension program of its own, and already works closely with the state extension agency. Although it did not have any convenios at the time of the visit, the school had received substantial support from the Rockefeller Foundation, both for equipment and for staff development.

\section{Schools of Home Economics}

Brazil has three schools of home economics. The demand for people trained in this profession is quite high, since home economists are used in extension programs. Given the present lack of professionally trained home economists, graduates of secondary schools are used for these positions. They are given intensive short courses to provide the necessary skils in home economics. 
The Escola Superior de Ciéncias Domésticas (Viçosa, Minas Gerais) was planned when the school was founded. A four-year courge was initiated in 1954 with the assistance of a specialist from Purdue University. Growth in enrollment was rapid, and there were about 100 students in 1962. Enrollment has remained pretty steady at this level since that time.

A second school of home economics was founded in Pelotas, Rio Grande do Sul, in 1961, with two graduates of the school at viçosa as teachers. A third school is the Faculdade de Ciéncias Domésticas in Rio de Janeiro. This school was private and provided a three-year course. It has had some difficulty obtaining adequate financial support.

Programs in home economics are being developed in at least two other schools--the Rural University at $\mathrm{Km} .47$ and the School of Agronomy at Piracicaba. Neither of these has a substantial program at the present time, however.

\section{Vocational Training in Agriculture}

Vocational agricultural training is given in large part through specialized secondary schools. In 1965 there were 26 agricultural ginasios and 37 agricultural colégios. The latter in many cases provide courses on both levels. The total enrollment in these schools in 1965 was 9,539 .

In general this is a much neglected link in the educational system. The schools have been sorely strapped financially, and little attempt has been made to upgrade the quality of their staff. Qualified teachers are scarce, and hence teachers have to be recruited from groups having only general knowledge of agriculture and little knowledge of teaching methods.

The role of vocational training in any country is at best a controversial issue. However, it would seem that such schools could be an effective device for upgrading the skill levels of the many who will be remaining on the farm.

It could be argued that vocational training should be provided only as one part of a more comprehensive school curriculum. However, it must be 
recognized that Brazil has opted for the present organization and has invested considerable resources in physical facilities and organization. The challenge is to upgrade these schools so that they make an effective contribution to the development process. This will require the upgrading of staff in technical agriculture, the strengthening of basic curricula so that students are given skills that do not have a high rate of obsolescence, and a careful evaluation of the role these schools might play in the overall development process.

Progress on these fronts will probably not be made until the university-level schools of agriculture assume a stronger leadership role in upgrading the staff and in curriculum development for the secondary schools. This is not likely to happen until these same agricultural schools become more directly concerned with the welfare of rural people in the states where they are located.

In recent years the schools of agronomy have become increasingly aware that they have a responsibility for lower-level agricultural education. The University of Parans negotiated a contract with the Ford Foundation and the University of Minnesota to develop teacher training programs for vocational agriculture. The Rural University at $\mathrm{Km} .47$ and the School of Agronomy at Piracicaba are also developing programs along these lines. It would seem that as a minimum the schools of agriculture should attempt to provide the intellectual leadership for the secondary schools, and concern themselves with providing capable staff for the lower-level teaching.

\section{AGRICULTURAL RESEARCH}

Brazil has a relatively large number of agricultural research stations that are rather widely distributed over its geographic area. The research that these stations are doing varies a great deal in both quantity and quality, however. Some stations are practically non-operational, while others have reasonably strong programs. This reflects, in part, historical developments in Brazil.

In the immediate postwar period, and perhaps even prior to this, a considerable amount of biological and agricultural research was undertaken. It 
was during this period that many of the present experiment stations were established, and biological research was probably at its peak around 1950 .

From that point on, however, such research began to taper off. The reasons for this are complex, but the primary reason is probably the strong emphasis given to industrialization during the decade of the 1950's. The agricultural sector was largely ignored by state and federal governments, and expanded budgets went for industrialization programs. The appropriations for agricultural research were eaten up by inflation, and the research capability was decimated. As an example, the Instituto Agronómico de Minas Gerais at Belo Horizonte, which at one time had approximately 100 engineer-agrónomos doing research, was reduced to two agrónomos by 1964. Similar declines occurred in other centers.

Since 1960 some attempt has been made to revitalize agricultural research. Additional resources have been made available for research, and there has been an effort to train capable researchers. However, the task is a very sizable one, and inflation continues to erode budget increases.

Agricultural research is undertaken by both the state and federal governments in Brazil. That supported by the state is usually undertaken in the state Secretariat of Agriculture, and that by the federal government is undertaken largely by the Ministry of Agriculture. In addition, there are some private agencies that perform experimental work.

In general, research institutions in Brazil are independent of both academic institutions and extension organizations. This independence has led to a certain lack of responsiveness of research programs to the needs of rural people.

To enumerate, evaluate, and appraise the existing research centers in Brazil would be a sizable undertaking. In this section the more limited objective is taken of attempting to characterize the existing research infrastructure, document to the extent possible the level of training of the researchers, and evaluate in a general way the character of the research programs. 
Research by the Federal Government

Prior to 1962 all research and experimental work under the Ministry of Agriculture was supervised by the Centro Nacional de Ensino e Pesquisas Agronbmicas (CNEPA), which included the Servico National de Pesquisas Agron6micas and the Rural University of Brazil. In the reorganization implemented in 1962, the research section became the Departamento de Pesquisas e Experimentação Agropecuárias (DPEA), which included the following sections:

1. Divisão de Pedologia e Fertilidade do Solo (soils)

2. Divisão do Fitotecnia (plant technology)

3. Divisão de zootecnia e Veterinaría (biological technology and veterinary medicine)

4. Instituto de Oleos (oil crops)

5. Instituto de Fermentação (alcohol)

In addition to these agencies, there were six regional agronomic institutes which combined work on crops and livestock problems. These were renamed as follows:

1. Instituto de Pesquisas e Experimentação Agropecuaria do Norte (IPEAN) at Belém, Para, with five experiment stations distributed over the North.

2. Instituto de Pesquisas e Experimentagão Agropecuaria do Nordeste (IPEANE) at Recife, Pernambuco, with eight experiment stations.

3. Instituto de Pesquisas e Experimentação Agropecuaria do Leste (IPEAL) at Cruz das Almas, Bahia, with four experiment stations.

4. Instituto de Pesquisas e Experimentação Agropecuária do Centro-Oeste (IPEACo) at Sete Lagoas, Minas Gerais, with seven experiment stations.

5. Instituto de Pesquisas e Experimentação Agropecuária do Centro-Sul (IPEACS) at $\mathrm{Km} .47$, Rio de Janeiro. 
6. Instituto de Pesquisas e Experimentação Agropecuaria do Sul (IPEAS) at Pelotas, Rio Grande do sul, with five experiment stations.

In 1968 the research organization of the Ministry of Agriculture was again reorganized and its name changed to the Department of Research and Experimentation. The basic divisions remained essentially the same, although two new institutes were formed: one in Mato Grosso and the other in Parana. These will strengthen the research effort in two rapidly growing agricultural areas, and also provide a much better geographic coverage for the nation as a whole.

The institutes have been seriously handicapped by inadequately trained staff, budget difficulties, the inability to employ their staff on a full-time basis, and the failure to concentrate their resources on important problems of their region. As a result, their contribution to creating a new technology, and to the modernization of Brazilian agriculture, has been small.

In 1966 the only one of the six institutes which had a reasonably well-trained staff was IPEAS, in Rio Grande do Sul. It had one Ph.D. and ten M.S.'s, most of these obtained from U.S. institutions.

IPEACO had only two MoS.'s among its staff in 1966, but it had 11 men working on the M.S. at either Viçosa or Piracicaba. IPEACs was the only other institute that had a reasonable number of staff with some advanced training.

Since 1966 a very substantial staff development program has been implemented. At the time of this writing there are some 50 people doing graduate work in U.S. institutions, in addition to a smaller number doing advanced study within Brazil.

The institutes have concentrated their work on crops, to the virtual neglect of animal agriculture. The only exception is IPEAS, which has been doing research in animal science for some 10 years.

Similarly, the research programs of the institutes have largely ignored the economic aspects of their technical research. The exception is again 
IPEAS, which has an agricultural economist who not only works with the state extension organization, but also conducts farm management research.

A list of 1,205 crop research projects, based on material obtained from the Ministry of Agriculture, was published by ABCAR in 1961. This list is summarized in Table 95. Of the 1,205 experiment station projects, 534 were concerned with the development or testing of crop varieties, and 423 were concerned with fertilizer. These two subjects of study together accounted for 80 percent of the total. They were followed by 74 experiments in the spacing of plants in the field, 63 experiments on date of planting, and from 20 to 30 each on (a) the use of insecticides or fungicides, (b) selection and treatment of seeds, and (c) various cultural practices.

Classified by crops, 289 experiments were concerned with sugarcane, 158 with corn, 103 with wheat, and 59 with coffee. Only one experiment was reported on bananas, and only one on cocoa. At the tiem of this survey, practically the only animal research was being done by IPEAS.

The character of the government research program has not changed greatly since that time. The livestock sector is now receiving more attention, although large programs have not yet been developed. Increased attention is also being given to forages for livestock production, and to soils. In addition, the government has plans to increase its economic research. It hopes to use economic analysis in establishing research priorities, and to study the farm management implications of the technical and biological research.

\section{Research by State Governments}

A number of states carry on agricultural research programs through the state Secretariat of Agriculture. The most effective of these are in Pernambuco, São Paulo, and Rio Grande do Sul.

In Pernambuco, the IPA (Instituto de Pesquisas Agron6micas), with headquarters at Recife, has a strong research program. The staff is highly trained, by Brazilian standards, and had $10 \mathrm{M}, \mathrm{S}$.'s and a couple of $\mathrm{Ph} . \mathrm{D} . \mathrm{I}^{\prime} \mathrm{s}$ in 1966. It has received 
TABLE 95

Agricultural Experiments, by Type, 1961

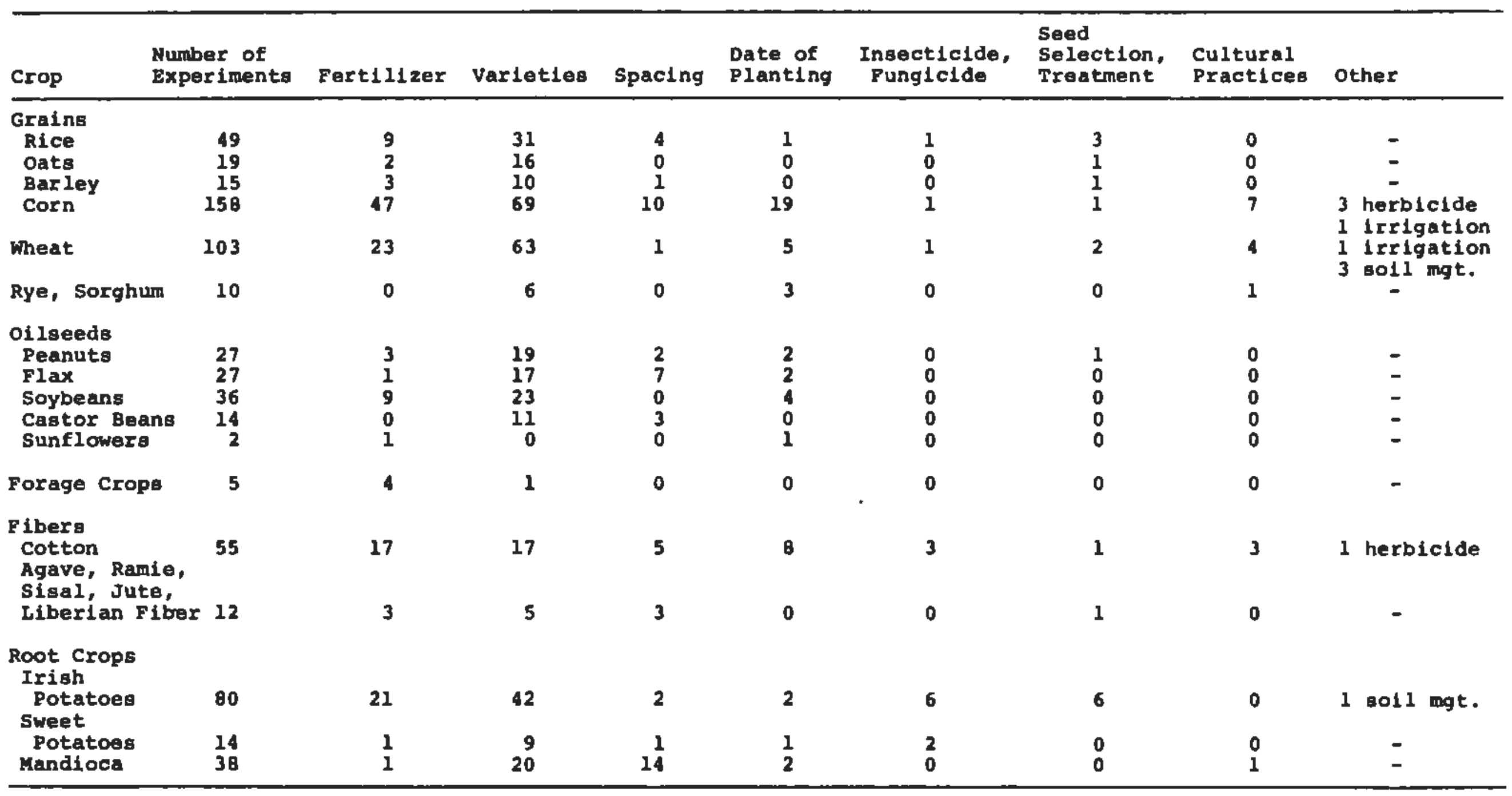




\begin{tabular}{|c|c|c|c|c|c|c|c|c|c|}
\hline Crop & $\begin{array}{l}\text { Number of } \\
\text { Experiments }\end{array}$ & Pertilizer & Varieties & Spacing & $\begin{array}{l}\text { Date of } \\
\text { Planting }\end{array}$ & $\begin{array}{l}\text { Insecticide, } \\
\text { Fungicide }\end{array}$ & $\begin{array}{l}\text { Seed } \\
\text { Selection, } \\
\text { Treatment }\end{array}$ & $\begin{array}{l}\text { Cultural } \\
\text { Practices }\end{array}$ & other \\
\hline \multicolumn{10}{|l|}{$\begin{array}{l}\text { Vegetable } \\
\text { Cropg }\end{array}$} \\
\hline Tomatoes & 23 & 5 & 11 & 2 & 0 & 0 & $\mathbf{0}$ & 5 & $=$ \\
\hline Others $\mathrm{a}$ & 45 & 20 & 15 & 1 & 3 & 0 & 1 & 0 & $\begin{array}{l}2 \text { herbigide } \\
2 \text { lunard } \\
1 \text { shading }\end{array}$ \\
\hline Fruitgb & 29 & 9 & 11 & 0 & 0 & 5 & $\mathbf{1}$ & 0 & 3 soll mgt. \\
\hline Coffee & 59 & 11 & 29 & 4 & 0 & 1 & 0 & 2 & $\begin{array}{l}3 \text { herbicide } \\
2 \text { irrigation } \\
3 \text { shading } \\
4 \text { soil mgt. }\end{array}$ \\
\hline Sugarcane & 289 & 199 & 74 & 5 & 0 & 2 & 3 & 4 & $\begin{array}{l}1 \text { herbicide } \\
1 \text { soll mgt. }\end{array}$ \\
\hline Coconuts & 10 & 9 & 0 & 0 & 0 & 0 & 0 & 0 & 1 irrigation \\
\hline Beans & 45 & 10 & 25 & 2 & 7 & 1 & 0 & 2 & - \\
\hline Tobacco & 22 & 15 & 2 & 2 & 1 & 1 & 0 & 0 & 1 shading \\
\hline Otherc & 19 & - & 10 & 5 & 2 & 2 & 0 & 0 & $=$ \\
\hline Total & 1,205 & 423 & 534 & 74 & 63 & 26 & 22 & 34 & \\
\hline
\end{tabular}

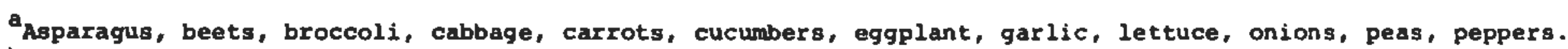

bApples, bananas, citrus, peaches, plums, pineapples, melong, watermelons, atrawberries.

cocoa, cowpeas, cashews, hibiscus, olives, rubber, velvet beans.

Influence of the phases of the moon.

Source: ABCAR; Minigtry of Agriculture; CNEPA. A complete 1igt, Indicador de Experimentos Agricolas (Rio de Janeiro: ABCAR, 1961) is kept at the SNPA office at $\mathrm{Km}$. 47. See also Ministry of Agriculture, "Indicador dos Trabalhos de Pesquisas e Experimentação" (R1o de Janeiro: Itagai, 1961). (Mineographed.) 
reasonably good support from the state over time, and hence has been able to maintain a good staff.

In Rio Grande do Sul, the state Secretariat of Agriculture maintains 11 experiment stations, plus the research program associated with the Rice Institute of the secretariat. The level of training of the staff is not high, however.

The strongest state research program and research infrastructure is in săo Paulo. The IAC (Instituto Agronómico de Campinas), is one of the best agricultural research centers in the country, and has worked effectively for improvement of agricultural practices in the state. It has 16 experiment stations scattered throughout the state.

The level of training of the staff in 1966 was as follows:

1. Degrees from abroad or working on them (M.S, Ph.D., or equivalent)

2. Degrees from Brazil or working on them (M.S., Ph.D., or doutoramento)

3. Non-degree graduate training abroad

4. Non-degree graduate training in Brazil

5. None of the above

Total

A serious problem in gaining additional training has been that the state government has not permitted a person to take leave for more than one year at a time. Because of this, it has been difficult to obtain even an $M . S$. and the valuable research training that it would have provided. The government has recently changed its policy on this, however.

Other research organizations within the state of São Paulo are as follows: 
1. Instituto Biolbgico (são Paulo). This institute was originally set up to do basic research. It had a technical staff of 237 in 1966, of whom 97 were agrónomos and 95 were veterinarians. At least 60 of the staff had spent some time abroad, although there had been no interest in obtaining advanced degrees. Five were studying abroad at the time of the visit.

\section{Divisão de Zootecnia e Nutricão Animal} (São Paulo). Of the 40 technicians in this division, two had the $\mathrm{M}_{0} \mathrm{~S}$. One was abroad working on the M.S., and four were at Piracicaba. In addition, three had studied abroad for periods of a year or more. A serious problem for this group is the lack of resources to finance animal research. The lack of animals prohibits research that required replications.

3. Departamento de Zoologia (São Paulo). This organization is devoted to basic research, and has an international name. The number of technicians was approximately 30 , with one of the staff having a $\mathrm{Ph} . \mathrm{D}$. from Harvard and another working on it. In addition, seven technicians had studied abroad for a year or more.

4. Tropical Research Center of Food Technology (Campinas). This is a new research center that has been functioning since 1963. Supported through a convenio with FAO, the arrangement was originally developed with the federal government and later transferred to the state of são Paulo. It is the only substantial research center on food technology in the country, although limited amounts of work are done elsewhere.

The plan is to work in the beginning only with products of plant origin, and expand at a later date to include work with animal products. The principal concern at the present time is with the processing of tropical fruits, especially bananas.

There were 30 technicians at the center in mid-1966, most of whom were agrónomos. Of these, four had an M.S. from Berkeley, and three others were abroad working on graduate degrees. Two others had studied abroad without obtaining a degree, and four were ready to go for degree work. 
The overall objective of the center is to improve the products currently being industrialized, and to develop new products. The primary mission is research. Teaching will be done only in collaboration with schools and universities.

Research by Non-Government Agencies

Three non-governmental agencies have made contributions to the research output in Brazil.

IRI, formerly known as the IBEC (International Basic Economy Corporation) Research Institute.

This agency was originally a non-profit organization founded by Nelson and David Rockefeller as part of the American International Association for Economic and Social Development. 4 The research program employed 12 technically trained persons in 1962. It has shown special interest in the use of fertilizers (including improvement of the campo cerrado soils) and animai nutrition.

In 1963 the name was changed to IRI and its principal support base changed to USAID. With a staff expanded to 40 technicians, it is carrying out a technical assistance program with the Ministry of Agriculture. In addition to its work in São Paulo, it now works nation-wide in carrying out its own research program and in providing assistance to the government's institutes.

\section{Anderson Clayton Company}

The principal interest of this company is in marketing coffee and cotton. However, the company has found it advantageous to help farmers improve their agricultural practices and obtain higher yields. It has an experiment station at Presidente Prudente, são Paulo (chiefly for fertilizer experiments), and also employs a number of agronomists to give advice and technical assistance to farmers from whom it purchases cotton or coffee.

\section{Agroceres}

This is a private seed company that was founded initially with partial funding from IBEC. Its primary product has been seed corn, and it has been a 
major contributor to the development of hybrid lines in Brazil. It now is starting work with edible beans and sorghum. The company has experiment stations in various parts of Brazil, and has made a major contribution to the total research effort.

\section{Other Research Institutions}

Two other research organizations are doing research that involves the technical aspects of agricultural production.

CEPLAC (Commissão Executiva, Plano de Recuperacão Economica Rural da Lavoura Cacaueira)

The zone of cocoa production in the state of Bahia has recently received research and extension support from a powerful, well-financed effort initiated by the federal government. Funds are derived from an export tax on cocoa ( 15 percent on beans and 5 percent on semi-processed materials). CEPLAC has responsibility and authority for all work with cocoa in Brazil.

Since its start in 1962 this organization has made considerable progress in building a structure under which much-needed research, extension, and credit programs can be developed in this very traditional area. It works primarily on problems of cocoa, but has also begun work on crop diversification and problems of the animal sector.

A technical staff of some 20 professional people was working on the research program in 1966. Only one of these, the director, had a Ph.D.; but they were sending staff to Viçosa and Piracicaba for graduate work. In 1966 five men had M.S.'s from Viçosa and Turrialba, and three were to complete the M.S. that year.

Centro Pan-Americano de Febre Oftosa (Pan American Foot-and-Mouth Digease Center)

This is a project of the Program of Technical Cooperation of the OAS and is administered by the Pan American Health Organization. The principal objective of the project is to assist in maintaining the freedom of those countries not affected with F-M-D and to assist those that are affected in 
achieving its control and eradication. The program of the center includes research, a service of virus diagnosis and identification, a training program, an advisory and consultative service, field studies, and the collection and dissemination of information. Twelve professionals and about 135 other persons were employed in 1966.

\section{Sumuary and Conclusions}

Although by no means an exhaustive coverage of all the research organizations that are working either directly or indirectly on agricultural problems, the above survey (together with that presented with the discussion of schools of agriculture) should give some flavor of the work that is being done, the source of support and organization, and the level of training of agricultural research workers in Brazil. Although there are numerous research centers and research stations, the lack of production research is one of the serious factors inhibiting the increase of productivity in the agricultural sector.

In broad terms, there are about five strong research centers or programs in Brazil. The strongest, most comprehensive program is in the state of São Paulo. The research infrastructure is reasonably well developed, has involved a comprehensive attack on the problems of the state, and has received sustained financial support. This research system has played an important role in the modernization of the agriculture of that state, as well as that of neighboring areas.

Other points of strength in the research structure are the federal institute in Rio Grande do Sul (IPEAS), the state experiment station at Recife in Pernambuco (IPA), CEPLAC in the cocoa zone, and the work on hybrid corn by Agroceres. Programs with considerable potential at the present time are the School of Agronomy at Piracicaba and the Rural University of Minas Gerais at Viçosa, as well as the general system in Rio Grande do Sul. If staff development efforts in the federal system are continued, and the funding becomes more dependable, this system could evolve into an effective development instrument. 
The research system has made some notable contributions to agricultural progress. Among these are the Novo Mundo variety of coffee; the sustained work on and improvements in cotton, especially in the South; the work with hybrid corn; and the fertilizer research and feeding trials in são Paulo. However; the potential of the physical infrastructure which is available has not been realized because of the low level of training of the research staff, the failure to establish priorities and mount concentrated research efforts, and the instability of funding.

The major problems that need to be faced in developing a more substantial research output are as follows :

1. The lack of stable financial support by both state and federal governments.

2. Low salaries for research workers, and a salary structure which does not compensate them for gaining additional training.

3. Lack of research training for experiment station personnel. Most of the technicians are trained at only the B.S. level, and have had little or no training in research.

4. Bureaucracy which prohibits the obtaining of advanced degrees by limiting the period of absence for advanced study.

5. Lack of contact with rural people on the part of researchers. As a result, they have little knowledge of the problems in the rural areas.

6. The repetition of a given set of experiments year after year, with little or no attempt to develop integrated attacks on problems being experienced by farmers.

7. Little or no attempt to relate research expenditures and effort to a priority scale based on the economic importance of the product.

8. Part-time employment, which divides the interest of the researcher and inhibits the development of depth studies. 
9. The lack of basic research, which potentially could make some breakthroughs having a substantial impact. Most of the research is highly applied, and involves nothing more than such things as variety trials and the evaluation of the response to fertilizer applications.

10. The institutional "setting," which involves research organizations set up as autonomous entities, with little or no underlying academic base.

Researchers in any country, or in any situation, almost always like to explore their own interests. They do this, however, at the risk of their financial support. The fact that most agronomos in Brazil come from urban backgrounds, plus the lack of communication with extension organizations, has made agricultural researchers in Brazil particularly insensitive to the needs of rural people.

Progress has been made in recent years in strengthening the research capability in Brazil, and considerable progress can be made in the future. The development of graduate training programs is providing systematic research training, and should facilitate the elevation of the research competency. The need for raising agricultural productivity is increasingly being recognized. And the research effort is being gradually shifted closer to a set of priorities consistent with economic importance. This is especially true in the case of expanded animal research. A great deal remains to be done, however, before Brazil can be said to have a research capability that will contribute to the modernization of the agricultural sector.

\section{EXTENSION SERVICES}

The predominant method of trying out and extending the results of research to farmers, and promoting increases in production in Brazil, has traditionally been fomento, which translates as "foment." Its basic idea is to stimulate production through the furnishing of technical services at no cost and inputs at a price below the market, with the government paying the difference. (Inputs provided range from seed distributed through state monopolies, to breeding stock, to tractor patrols for 
plowing and other activities.) Its principal concern is not to educate the farmer to produce more and better, but rather to furnish him with technical services and the inputs that he needs at cost or less. It is a crop- and animal-oriented program rather than, a people-oriented program. Under the system it is not important that the farmer learn techniques, since there are technicians to work for him, free.

For various reasons the fomento organizations have not worked well. They tend to be dominated by politicians, who use them as a political instrument, and by the larger farmers. The system is a heavy resource user, in both human and financial terms, which limits the impact that it can have. The resources made available for the purchase and sale of inputs are rapidly eaten up by inflation and soon become insignificant. There is little or no training of technicians. And the administration is highly centralized and slow-moving.

Because of these problems, the concept of fomento has become so discredited that various recent organizations, even though of the traditional fomento form, have refused to use the name explicitly in their title or in the description of their programs. For example, in the Ministry of Agriculture, the name was changed from Serviço de Fomento Federal to (Service of Federal Foment) to Serviço da Promogão Agropecuário (Service of Agricultural Promotion). Even so, the majority of technicians charged with taking modern techniques to farmers still belong to organizations that use fomento methods. The only thing that has happened has been a change in name.

The concept of rural extension as a peopleoriented or adult education program was introduced into Brazil only recently. Its introduction coincided with the creation of ACAR (Associação de Crécito e Extensão Rural) in Minas Gerais in 1948.5 Prior to this there was a pilot project in Santa Rita de Passo Quarto, in săo Paulo, but this never went beyond the pilot project stage.

However, ACAR was not created to do rural extension in the traditional way, but rather to develop in Minas Gerais a program of supervised credit along the lines of the Farmer's Home Administration in the United States. It was soon realized, however, that this was not the type of program that Brazil needed, 
and around 1953 the idea of an extension service along more traditional lines took form. By 1956 this idea essentially won out, and ACAR became the extension service of Minas Gerais. The supervised credit, and later the oriented credit which practically replaced it, became only one of its instruments for stimulating the adoption of new technology.

The new idea was to accelerate the adoption of new practices by furnishing credit to the innovation leaders. The credit was supposed to facilitate the adoption of the new practices more rapidly, since it reduced or eliminated any financial restrictions (capital rationing). The financial resources for the credit were furnished by the Caixa Econ6mica de Minas Gerais and the Bank of Brazil, with the former predominating.

ACAR attempted to avoid the errors of fomento. since a large part of the initial resources came from the American International Association (AIA), and thanks to the goodwill of the state-government, it was possible to disconnect ACAR from the political control of the state Secretariat of Agriculture. It remained subordinated to the government, however, through the constitution of a governing junta for administering it. Through this expedient, politics were essentially kept out of ACAR from the beginning.

In addition, much of the success of ACAR is due to its rather gradual development, in contrast with the overextended implantation associated with many such programs in Brazil. Only four local offices were created initially; and the idea expanded little by little, as experience was obtained and technicians for the direction of the organization were trained in Brazil and abroad. In addition, the external help to ACAR was gradually diminished as the contribution of the state increased; and in 1956 the AIA pulled out completely.

In the early days of ACAR the program was restricted essentially, to small farmers. If the goal of the program had been social welfare, this would have been a valid form of action. However, if the goal was to increase agricultural production, which could result in a broader base for the distribution of the gains from development, this approach had serious limitations. In recent years, the program has been extended to larger farmers, especially in 
its technical assistance aspects, with the credit programs left primarily to the small farmers--those most likely to be experiencing capital rationing.

By 1954, ACAR was already considered to be a strong institution--so much so that it influenced the creation of ANCAR, a similar organization for attending to the needs of the various states of the Northeast. ANCAR was in turn subdivided, and today each state of the Northeast has its own organization. At later dates similar organizations were created in Rio Grande do Sul (ASCAR), Santa Catarina (ACARESC), Parana (ACARPA), and Esplrito Santo (ACARES). Today 18 of the 22 states of Brazil have a rural extension service.

In 1956, ABCAR, the national organization, was created and from then on, the idea of extension as a training program has increasingly penetrated the federal sphere. Support has developed to the point where the federal government now provides at least 60 percent of the resources for the state organizations. When INDA, the National Institute for Agricultural Development, was created in 1964, ABCAR became the executive organ for its extension activities. Although now financed in large part by INDA, ABCAR has maintained its administrative autonomy.

Thus the extension service, which was born and developed outside of the Ministry of Agriculture, is today incorporated into it financially, although maintaining its fundamental characteristics. The current trend is towards closer and closer relations, since there is a general acceptance of extension methods by the Ministry of Agriculture. Even the latter's services of fomento are attempting to modernize themselves, and are rapidly adopting the techniques of extension. A typical case is PLAMAM, (Plano de Melhoramento da Alimentasão e do Manejo do Gado Leiteirol a hybrid of extension and fomento formed to serve the dairy farming sector.

It is still quite early to juage definitively the contribution of rural extension to increasing agricultural productivity in Brazil. Only a small part of the municipios are reached by this service, and the majority of the local offices have been operating for less than five years. But the following points are important: 
1. In a little over 15 years, the idea of extension has become accepted in Brazil.

2. In the formulation of agricultural policy, at both the state and federal level, the influence of the extension service is substantial.

3. The extension service has helped greatly in raising the prestige of the agronomo in public opinion.

4. The rural universities and schools of agriculture have accepted the idea and have introduced courses in rural extension into their curricula.

Two major problems are confronted in increasing agricultural productivity. One is the general lack of research relevant to Brazilian problems. One could say almost categorically that the extension capability is better developed than the research capability. The second problem is the high degree of illiteracy in rural areas, which makes the distribution of knowledge difficult and increases the cost of extension programs.

\section{Administrative Organization of ABCAR}

ABCAR is the coordinating organ of rural extension in Brazil. It centralizes the federal resources and distributes them to the state services in accord with criteria consistent with its internal policy. It does not have an executive function, however, Rather, it maintains a technical staff for establishing contacts with the federal government and for helping the state services. It is considered to be an institution of public utility, and has an administrative junta composed of representatives from the institutions that finance it.

In the several states there are state extension services, which are autonomous and are financed by the federal government through ABCAR, and by the state governments. (The federal government contributes at least 60 percent of the resources.) The state services are headed by an administrative junta, composed of representatives of ABCAR and of the state and federal governments. This junta elects the general secretary, who really directs the service. He is aided by a staff of the central office, and by 
regional offices, which form the administrative body of the service. The work is taken to the farmers by local offices, which in general work in only one municlpio. Basically, the local team is composed of an agronomo and a home economist, both of whom are specially trained in the techniques of rural extension through pre-service courses and by in-service training. (The courses last for 40 days, plus three months of visits and work in the field.)

The agronomos are typically graduates of the four-year, college-level schools of agronomy, although increasing use is being made of graudates of the secondary-level technical schools. The home economists may be graduates of the few college-level schools of home economics, although the bulk of them are graduates of normal schools. (Normal schools correspond to one to two years beyond U.S. secondary schools; and provide teacher training.)

The system of work is tempo integral, or fulltime employment. This is a considerable advantage, and one which has contributed significantly to building a strong program. The employees are subject to the workers' laws, and not to the statute of public funcionalismo. In general the ABCAR system has been able to pay higher salaries than other government organizations.

\section{Expansion of State Services}

Sumnary data on the 12 state agencies that have been in existence long enough to be well established are presented in Tables 96 and 97 . Six other states have created ABCAR organizations sibce 1960 .

The data indicate a number of important characteristics of the extension organization. First the organization is still quite limited in its scope. oniy a small fraction of the counties (municipios) in each state are being reached, the expenditure per rural inhabitant is extremely small, and the average rural population served by one technician is quite large. Expenditures per rural inhabitant are overestimated and rural population per technician is underestimated because population data for 1960 were used in comparison with expenditure and technicians data for either 1965 or 1966 . 
TABLE 96

State Extension Agencies: Budgets and Population Ratios

\begin{tabular}{|c|c|c|c|c|c|}
\hline state & Agency & $\begin{array}{c}\text { Year } \\
\text { Founded }\end{array}$ & $\begin{array}{l}\text { Total } \\
\text { Budget } \\
1966\end{array}$ & $\begin{array}{c}\text { Budget } \\
\text { per } \\
\text { Rural } \\
\text { Inhabitant }\end{array}$ & $\begin{array}{c}\text { Rural } \\
\text { Inhabitants } \\
\text { Per } \\
\text { Technician }\end{array}$ \\
\hline $\begin{array}{l}\text { Minas Gerais } \\
\text { Santa Catarina } \\
\text { Espirito Santo } \\
\text { Ceará } \\
\text { Parana } \\
\text { Rio Grande do Sul } \\
\text { Pernambuco } \\
\text { Bahia } \\
\text { Rio de Janeiro } \\
\text { Goias } \\
\text { Rio Grande do Norte } \\
\text { Paraiba }\end{array}$ & $\begin{array}{l}\text { ACAR } \\
\text { ACARESC } \\
\text { ACARES } \\
\text { ANCAR-CE } \\
\text { ACARPA } \\
\text { ASCAR } \\
\text { ANCAR-PE } \\
\text { ANCAR-BA } \\
\text { ACAR-RJ } \\
\text { ACAR-GO } \\
\text { ANCAR-RN } \\
\text { ANCAR-PB }\end{array}$ & $\begin{array}{l}1948 \\
1956 \\
1956 \\
1964^{\mathrm{C}} \\
1956 \\
1955 \\
1964^{\mathrm{C}} \\
1964^{\mathrm{d}} \\
1958 \\
1959 \\
1959 \\
1964^{\mathrm{d}}\end{array}$ & $\begin{array}{r}\$ 1,729,318 \\
672,363 \\
457,136 \\
642,500 \\
432,545 \\
804,136 \\
517,272 \\
253,636 \\
363,773 \\
339,682 \\
319,727 \\
430,818\end{array}$ & $\begin{array}{l}.29 \\
.43 \\
.52 \\
.28 \\
.11 \\
.26 \\
.22 \\
.06 \\
.26 \\
.22 \\
.44 \\
.32\end{array}$ & $\begin{array}{r}29,290 \\
22,672 \\
18,386 \\
67,061 \\
109,259 \\
35,750 \\
87,692 \\
195,350 \\
73,667 \\
90,400 \\
30,083 \\
48,518\end{array}$ \\
\hline
\end{tabular}

aconverted from cruzeiros at the average exchange rate for the year.

bopulation data are for 1960, since no state data were available for 1966 .

CFounded as a part of ANCAR, the original organization for the Northeast. In 1964

ANCAR was broken up into state units.

doriginally created in 1955, but separated from ANCAR in 1964. 
TABLE 97

Expansion of state Extension Organizations, 1960-1966

\begin{tabular}{|c|c|c|c|c|c|c|c|c|c|c|}
\hline State & $\begin{array}{l}\text { Number of } \\
\text { Municípios } \\
\text { (1965) }\end{array}$ & $\begin{array}{r}\text { LOC } \\
1960\end{array}$ & $\begin{array}{l}\text { cal } 0 \\
1966\end{array}$ & $\begin{array}{l}\text { ffices } \\
\text { Percent } \\
\text { Increase }\end{array}$ & $\begin{array}{l}\text { Munic } \\
1960\end{array}$ & $\begin{array}{l}\text { cipios } \\
1966\end{array}$ & $\begin{array}{l}\text { s Reached } \\
\text { Percent } \\
\text { Increase }\end{array}$ & 1960 & $\begin{array}{l}\text { chni } \\
\text { Emplo }\end{array}$ & $\begin{array}{l}\text { cians } \\
\text { yed } \\
\text { Percent } \\
\text { Increase }\end{array}$ \\
\hline $\begin{array}{l}\text { Minas Gerais } \\
\text { Santa Catarina } \\
\text { Espírito Santo } \\
\text { Ceará } \\
\text { Paraná } \\
\text { Rio Grande }\end{array}$ & $\begin{array}{r}722 \\
190 \\
53 \\
303 \\
273\end{array}$ & $\begin{array}{l}62 \\
25 \\
11 \\
10 \\
14\end{array}$ & $\begin{array}{r}140^{a} \\
71^{a} \\
41^{a} \\
49^{a} \\
44\end{array}$ & $\begin{array}{l}226 \\
284 \\
373 \\
490 \\
314\end{array}$ & $\begin{array}{l}95 \\
28 \\
12 \\
18 \\
14\end{array}$ & $\begin{array}{c}207^{a} \\
102^{a} \\
39^{a} \\
52^{a} \\
44\end{array}$ & $\begin{array}{l}218 \\
364 \\
325 \\
289 \\
314\end{array}$ & $\begin{array}{r}200 \\
64 \\
44 \\
33 \\
27\end{array}$ & $\begin{array}{r}313^{a} \\
115^{a} \\
72^{a} \\
104^{a} \\
55^{a}\end{array}$ & $\begin{array}{l}156 \\
180 \\
164 \\
315 \\
204\end{array}$ \\
\hline $\begin{array}{l}\quad \text { do Sul } \\
\text { Pernambuco } \\
\text { Bahia } \\
\text { Rio de Janeiro } \\
\text { Goiás } \\
\text { Rio Grande }\end{array}$ & $\begin{array}{r}194 \\
182 \\
336 \\
63 \\
221\end{array}$ & $\begin{array}{r}25 \\
9 \\
8 \\
6 \\
6\end{array}$ & $\begin{array}{l}42 \\
36 \\
25 \\
33 \\
23\end{array}$ & $\begin{array}{l}168 \\
400 \\
288 \\
550 \\
383\end{array}$ & $\begin{array}{r}25 \\
9 \\
14 \\
6 \\
10\end{array}$ & $\begin{array}{l}53 \\
68 \\
40 \\
38 \\
40\end{array}$ & $\begin{array}{l}212 \\
755 \\
285 \\
633 \\
400\end{array}$ & $\begin{array}{l}84 \\
26 \\
20 \\
18 \\
15\end{array}$ & $\begin{array}{r}109 \\
64 \\
45 \\
75 \\
47\end{array}$ & $\begin{array}{l}130 \\
246 \\
225 \\
417 \\
313\end{array}$ \\
\hline $\begin{array}{l}\text { do Norte } \\
\text { Paraíba }\end{array}$ & $\begin{array}{l}152 \\
168\end{array}$ & $\begin{array}{l}8 \\
9\end{array}$ & $\begin{array}{l}31 \\
40\end{array}$ & $\begin{array}{l}388 \\
444\end{array}$ & $\begin{array}{l}20 \\
21\end{array}$ & $\begin{array}{l}42 \\
64\end{array}$ & $\begin{array}{l}210 \\
305\end{array}$ & $\begin{array}{l}24 \\
27\end{array}$ & $\begin{array}{l}46 \\
59\end{array}$ & $\begin{array}{l}192 \\
218\end{array}$ \\
\hline
\end{tabular}

a1965 data. 
However, since 1960 all of the state organizations have expanded rapidly. The number of local offices has increased, the number of municípios reached has grown greatly, and the number of technicians employed has also increased. It should be noted in passing that further expansion of this system can provide a ready market for the rapidly expanding colleges of agriculture.

\section{Evaluations of ABCAR-Type Programs}

Because of the pioneering nature of the extension program when it was introduced in ACAR, the latter organization has been studied by a number of researchers both from within and from outside the organization. Ribeiro and Wharton have summarized these studies, as well as provided their own evaluation of the overall effectiveness of the organization. 6

The early detailed studies of the impact of the extension program on agricultural output and technical efficiency have given a rather mixed picture, but tend towards a favorable evaluation. They have shown that the ABCAR-type programs are capable of increasing yields for individual crops and of increasing total factor productivity in municípios which have ABCARtype programs, compared with municípios that do not have.

A more recent study, however, has shown a negative result. 7 In this most recent evaluation, it appears that the subsidized credit program, which has been used in a highly inflationary milieu, has led to more resource accumulation than increased agricultural output. The result is a lower level of technical efficiency for those farms working with ABCAR than for those not working with it. Although this study is by no means definitive, since it was based on a small sample, it does raise serious questions about the role of a subsidized credit program in raising technical efficiency.

\section{Other Extension-Type Organizations and Activities}

Two other major government agencies conducted some type of extension activities throughout the nation in 1966. These were the SIA (Servigo de In- 
formação Agrícola) and the DPA (Departmento de Promoção Agropeuario). This latter department united in a single agency the "extension" work of the divisions concerned with promoting the production of crops and livestock. In addition to the activities of these two organizations, the Information Service of the Ministry of Agriculture prepares and distributes bulletins and circulars, and conducts some radio and film programs of an extenston type.

The largest of the federal extension-type agencies in the past was the Division for Promotion of Crop Production (DFPV). Its duties are now performed by the DPA. In each state DFPV maintained an Inspectoria Regional de Fomento da Produção Vegetal (Inspector's office to Promote Crop Production). Each of these state offices had under its charge a number of circunscriçöes agrícolas) (agricultural areas) and postos agropecuarios (agricultural posts). There were 262 posts throughout the country in 1962 , as well as units to deal with seed production, farm machinery, and irrigation. In $1962 \mathrm{DFPV}$ was reported to employ 391 agrónomos, of whom about 20 had been loaned to work with other agencies, such as ABCAR and the state extension service.

Extension-type work on livestock problems was under the Division to Promote Animal Production (DFPA) until it became part of DPA in 1962. DFPA was a smaller agency than DFPV. It had nine Inspectorias Regionais de Fomento da Produção Animal (Inspector's Office to Foment Animal Production) in the field, plus another one for silkworm culture. Under these inspectorias were a number of cattle ranches, poultry demonstration plants, and demonstration fields for various crops. In 1962 DFPA had 18 veterinarians and 34 agronomos on its permanent staff, and 14 technicians on temporary assignments. The successor organization has expanded work in this area.

Both of these organizations were concerned primarily with fomento, and not with extension in the classic sense of informal education. The same applies to the DPA, which has replaced them.

In 1964 a new organization called INDA was formed. This is part of the federal agrarian reform program, and in concept takes a broad approach to rural development. (Its sister organization, created at the same time, is IBRA, the Instituto Brasileiro 
de Reforma Agraria, which has primary responsibility for agrarian reform programs.) It includes extension as part of its activities, and implements programs of this type through the ABCAR system. But the majority of its programs are action-oriented, including work with cooperatives and model communities, plus a great many fomento-type activities. It is too early to assess the contribution that this agency will make, but its financial support is quite strong.

Some states have extension-type services of their own. The most outstanding of these is found in São Paulo, which has not joined the ABCAR system. The extension agency in that state is the Departamento de Produção Vegetal (Department of Vegetable Production) for the state Secretariat of Agriculture.

In 1962 the são Paulo system had nearly 400 local extension offices (casas de lavouras). The four-year State Plan for 1959-1963 provided for demonstration farms for about 300 of these. More than 900 out of a total of some 1,100 agrónomos in the state Secretariat of Agriculture were employed in this service.

Although the São Paulo extension system is more fomento-oriented than extension-oriented, it is more closely integrated and closely related to research work than is the national extension service. Through the training center located in Campinas, the local agronomos are continually brought up to date on research results and provided with other upgrading courses and programs.

An additional extension-type organization is associated with CEPLAC, which works in the cocoa zone of Bahia. Besides its research activities, it is also developing a substantial extension service, involving fomento, supervised credit, and extension in the ABCAR sense. In 1966 it had about 70 agrónomos either engaged actively in extension and credit work or in training for extension and credit supervision work. It had 21 local offices located in the municipios for this work.

\section{Conclusions}

The tradition of fomento remains strong in Brazil, with a major portion of extension-type resources going for such activities. However, the concept of extension is spreading rapidly, and the 
ABCAR extension services are tending to develop quality programs. Financial support, especially at the state level, is a continuing problem, as is the tendency to work with the small farmer. If an adequate base of biological and technical research could be developed, a shift towards more work with larger farms would be facilitated. The number of farmers actually reached by extension activities is still quite small, and the impact on total agricultural production is also probably quite small.

On the other hand, ABCAR has made some outstanding studies of agricultural problems in Brazil, and has held training courses for extension workers and technical personnel in related fields. Its attention to the upgrading of its own professional staff is admirable.

In recent years there has been considerable activity in the organization of 4-5 clubs for rural youth that are similar to the 4-H clubs in the United states. In most cases ABCAR includes $4-5$ work in its programs. In the state of Rio Grande do sul there are two groups concerned entirely with youth programs.

\section{INTEGRATION OF TEACHING, RESEARCH, AND EXTENSION}

Teaching, research, and extension tend to be carried out by separate institutions in Brazil. The major exceptions are the rural university at Viçosa, which is unique in conducting all three activities; Piracicaba (ESALQ), which conducts both teaching and research; and CEPLAC, which conducts both research and extension.

In general, the communication among the three functions is quite weak. Researchers tend to work in a vacuum, with little or no dialogue with the extension agent as a basis for knowing what problems rural people are facing. Extension people are not always well informed about the latest reserach findings. The teaching tends to have little contact with current research.

There are important exceptions to each weakness, and there is a growing awareness of the importance of communication. However, there is 
considerable room for progress in this important aspect of integration. The maximum payoff from expenditures in teaching, research, and extension will not be had until this communication process is improved.

The integration can occur without placing all three functions under the same administrative organization. However, a conscious effort has to be made to increase the exchange of ideas and information.

\section{CAPABILITY FOR ECONOMIC POLICY ANALYSIS}

The govermment sector plays a very active role in the Brazilian economy. Its impact is felt throughout the economy, and intervention takes place in a very direct way. Despite this, the capability for economic analysis and evaluation of alternative policies is rather limited. There are two reasons for this. In the first place, technocrats or technicians have had very little influence on policy matters until recently. Any contribution they could have made would most likely have been ignored, in deference to more immediate political exigencies.

Equally important, however, is the shortage of competent analytical economists in the country. Enrollment in economic faculties has been relatively high compared with other disciplines. However, the lack of rigor in these programs, plus the failure to emphasize theory and analytical economics, in contrast with institutionalism and an overriding concern with problems of equity or how to divide the economic pie, have inhibited the development of an analytical competence.

The problem is even more serious in regard to agricultural economics. until recently the number of qualified agricultural economists in Brazil was extremely small. In the schools of agronomy the chair of agricultural economics was just one of many, and usually had the least prestige. Little or no specialization took place at the undergraduate level. In addition, the economics faculties have largely ignored agricultural economics as a specialty field.

This picture is rapidly changing. The graduate program at Viçosa has produced some $70 \mathrm{M.S}$.'s in agricultural economics since 1960. Compared with the 
5-10 people with such degrees at that time, this represents a significant increase. In addition, some 10 students are in various stages of completion of Ph.D. programs, and should be returning to Brazil soon.

The basic analytical competence for policy analysis is in five institutions.8

1. Banco do Nordeste (Bank of the Northeast)

Two groups of economists concerned with agricultural economics have been formed within this large development bank. Two of the staff have M.S.'s from Vicosa, and others have studied for limited periods of time abroad, including a couple who have M.A.'s. The remainder, however, are primarily graduates of economics faculties, with post-graduate training provided by ECLA (Economic Commission for Latin America). The OAS has provided one man for technical assistance.

The two groups have made a significant contribution to the research literature on the Northeast, and have a great deal of potential. However, their level of training needs to be upgraded, and their research effort needs to be concentrated more on the diagnosis of the problems of the Northeast, and less on the short-term policy needs of the bank.

2. Divisão de Economîa Rural (Division of Rural Economics) Secretariat of Agriculture, são Paulo

For a long time this was the only group doing significant economic research on agricultural problems in Brazil. It may still be the leader in analyses which directly affect and influence agricultural policy.

The divisão collects a wide variety of economic data on markets, on prices, and on trends at the farm level. In addition, it does studies which evaluate current economic developments in the agricultural sector, evaluates both state and national agricultural policy, and undertakes research of a more basic nature, such as farm management, marketing, supply and demand for farm products, and so forth.

It has a reasonably well trained staff. of a professional staff of 36 in 1966; four had M.S."s 
from U.S. universities, three had M.S.'s from Viçosa, two were working on degree programs abroad, and others were pursuing degree programs at viçosa and Piraçicaba. A large fraction of the staff have had post-graduate training either in Brazil or abroad. In addition, strong internal programs of staff development have been carried out over a period of time, and in recent years some technical assistance has been received from the USAID-Ohio state project at Piracicaba.

The national impact of this group has been limited by its being a state organization. However, são Paulo is an important state, and is pivotal in many matters. The group has not hesitated to analyze national policy issues and, particularly on coffee policy, has historically made an important contribution. The director of the divisão is usually respected by the state government, and is called upon for advice and analysis in many matters. The key role of this state in the nation enables this advice to be channeled into national policy-making discussions.

The staff could effectively utilize additional formal training, and a relatively low pay scale has made recruiting difficult. But this group has played, and can continue to play, an important role in attaining a more rational economic policy for agriculture.

\section{Instituto de Economía Rural (Institute of Rural Economics) UREMG (Viçosa)}

UREMG is the leading training center for agricultural economists in Brazil, and perhaps in Latin America. It carries on a substantial research program through its graduate training. Each student must do a thesis, which is published as a research bulletin.

It has a relatively large (13), well-trained staff. Four of the men either have the Ph.D. or are nearing completion, and eight have the M.S. Additional people are being sent abroad for doctoral work.

This group has multiple objectives, however. They carry a heavy teaching load, both in the undergraduate specialization program and in the graduate program. The research has a very broad base, ranging 
from farm management and production economics, to marketing, to rural development and macro-economic studies. It has not given the attention that it might have to analyses of current economic policy, although it is increasingly being called on for this kind of work. The geographic isolation of the institute inhibits somewhat the involvement in day-today policy evaluation, although given a decision on their part to do more policy work, this geographic isolation may be an advantage.

As part of UREMG, the institute has shared in the USAID-Purdue University contract. Starting in 1958, it had one Purdue professor; in 1962 this was increased to two; and since 1963 it has had three. These professors have helped teach the graduatelevel courses and have provided assistance in the research program.

The Ford Foundation has contributed substantially, with financial resources for the construction of a new building, salary supplements for maintaining quality staff, scholarships, and research support. USAID has also contributed in financing research, scholarships, and equipment.

4. Departamento de Estudos Rurais (Department of Rural studies), Secretariat of Agriculture, Minas Gerais (Belo Horizonte).

This group was established in 1963 on the basis of a grant from the Ford Foundation. starting with nothing in 1964, it has developed a reasonably strong data collection service for the state of Minas Gerais, and the basis for a strong economic analysis group.

Patterned in many respects after the Divisão de Economia Rural in São Paulo, the group will carry out essentially the same functions. So far the major fraction of its energies has gone into growing, since it needed to develop a complete administrative organization and provide substantial on-the-job training. It has made a major contribution, however, in setting up a data collection service for the state, in collecting and publishing market and price information, and in building a base for crop forecasting and outlook work. Few organizations could have grown as rapidly and done as much in such a short period of time. 
of a total staff of 62 at the end of 1966, six were agricultural economists and seven were agrónomos. The agricultural economists all had the M.S. from Viçosa and one had completed prelims for the Ph.D. in the United states. Additional staff were working on graduate degrees at Vicosa, and one was working on a Ph.D. in the United States. Two additional staff will be sent to the United states in the near future for $\mathrm{Ph} . \mathrm{D}$. work.

This group has not yet made a significant contribution to the analysis of agricultural policy because of its correct decision to develop its data base and concentrate on staff development. However, its short-term studies and evaluations have made a contribution to both state and national discussions, and the market information generated contributes to improved performance of the decentralized economy. This group has the potential to make a significant contribution in the future. The major problem will be in obtaining continued support from the state government.

\section{Fundação Getulio Vargas (FGV).}

The FGV is a major economic research and teaching center in Brazil. It is responsible for the national accounts, and collects and publishes great deal of current economic information on the general economy. Its staff is competent and welltrained, although small.

Within IBRE, its research arm, there is a section of agricultural economics. The professional staff of agricultural economists is small, consisting of the current director of IBRE, who did advanced work at the Sorbonne; the former director of the Divisão de Economía Rural of São Paulo, who has done graduate work in the United States; and the current director of the agricultural sector.

Despite the small professional staff, the FGV has produced a number of depth studies. One was an evaluation of the food processing industry in Brazil. $A$ second was a set of demand and supply projections for agricultural products in 1975. Another was a depth study of agricultural productivity, carried out in conjunction with Vanderbilt University. These are important studies for long-run planning and 
development policy. The FGV has done less work in evaluating and suggesting short-run policy alternatives.

Given the strong staff in general economics which this institution has, and its growing competency in empirical research, it could well strengthen its capability for policy work in agricultural economics. It is strategically located geographically, and is part of the general policy-making milieu.

\section{Other Organizations.}

In addition to these five institutions, two other groups are in key positions in the decisionmaking process. The economic group of the Ministry of Agriculture has coordinated the developing market information services and the crop forecasting service. However, the small professional staff which it has (three Vicosa M.S.'B in agricultural economics in $1966)$ and governmental bureaucracy prevent it from playing a greater role.

The Ministry of planning has an economic research group and is showing an increasing interest in policy research. However, it does not have the capability (one Viçosa M.S.) as yet to carry out a significant program, and has been forced to contract out most of its work.

\section{Conclusion}

The capability for research in agricultural economics is growing rapidly. In addition, the political power of the technocrats is growing, although it is still limited. Competent economic analysis of current policy issues would, however, at least obtain a good hearing. The major problem is the lack of a single organization that is putting major resources into policy analysis.

\section{SUMMARY AND CONCLUSIONS}

Brazil has the base for a viable research and education infrastructure that will serve the agricultural sector. It is a long way, however, from having a system which can effectively bring the tools 
of science and technology to bear on the problems of modernizing Brazilian agriculture. Perphas the most serious lacks are lower-level education for rural people, good production and economic research, and highly trained manpower. Higher-level education and the extension service both have some strong bases to build on, although much remains to be done in each.

It is important to recognize that strengthening the total education and research structure in Brazil can help the agricultural sector. The strengthening of basic scientific and technological work can have significant spillovers into the agricultural sector, as can the strengthening of social sciences, such as sociology and economics.

\section{NOTES}

1. See Zvi Griliches, "The Sources of Measured Productivity Growth: United States Agriculture, 1940-1960," The Journal of Political Economy, LXXI, 4 (August, 1963), 331-362; "Research Expenditures, Education and the Aggregate Agricultural Production Function," American Economic Review, LIV (December, 1964), 967-978.

\section{Ibid.}

3. Griliches, "Research Expenditures .. - ," provides estimates of the social rates of return to education and research. T. W. Schultz has summarized our current knowledge on social rates of return to investments in research in The Allocation of Resources to Research, "University of Chicago, Agricultural Economics Papers," No. 68:16 (December, 1968). Earlier work on the economics of education can be found in T. W. Schultz, The Economic Value of Education (New York: Columbia University Press, 1963); Gary Becker, Human Capital (New York:Columbia University Press, 1964).

4. For a history of the American International Association, see Martha Dalrymple, The AIA Story, Two Decades of International Cooperation (New York: AIA, 1968). 
5. For an excellent description and evaluation of the ACAR program, see Jose P. Ribeiro and Clifton R. Wharton, Jr., "The ACAR Program in Minas Gerais, Brazil," in Clifton R. Wharton, Jr., ed., Subsistence Agriculture and Economic Development (Chicago: Aldine Publishing Co., 1969).

\section{Ibid.}

7. Eliseu R. A. Alves and G. Edward Schuh, "An Economic Evaluation of the Impact of an Extension Program: ACAR, Minas Gerais, Brazil" (Purdue University). (Mimeograph.)

8. For a more detailed analysis of the profession of agricultural economics in Brazil, plus an evaluation of the research completed in the last 10 years, see G. Edward Schuh, Research on Agricultural Development in Brazil (New York: Agricultural Development Council, forthcoming). 


$\begin{array}{ll}\text { CHAPTER } & \begin{array}{l}\text { OTHER ASPECTS OF THE } \\ \text { INFRASTRUCTURE AND } \\ \text { SUPPORT FOR AGRICULTURE }\end{array}\end{array}$

The research and education system is only one aspect of the infrastructure that provides services to the agricultural sector. This chapter is devoted to a discussion of other public institutions and organizations which operate at the national level, the regional development agencies, the budget support for agriculture from national and extranational sources, agricultural policy, and the public attitude toward and support of agriculture.

\section{PUBLIC INSTITUTIONS AND ORGANIZATIONS}

In this section a brief description of the major public institutions servicing agriculture is presented. The organizations discussed are either national in scope or are similar in the various states. The section terminates with a discussion of general administrative problems within Brazil.

\section{Federal Ministry and State Secretariats of Agriculture}

The traditional public organizations servicing the agricultural sector have been the Ministry of Agriculture and the parallel state secretariats of Agriculture. In the postwar period the Ministry of Agriculture has not been a strong sector of the government. It has been continually strapped for financial support, plagued with part-time employment, unable to recruit and retain high-quality staff, and demoralized by periodically having functions stripped from it and given to other institutions. This attrition has been going on for a considerable period of time. 
The ministry is organized in such a way that it has direct contact at the local level. Its various departments and services have sections and stations at the state level. The plan has been for all sections to be represented in each state, although this has been accomplished only in part.

Brazil is currently attempting to implement an administrative reform at the federal level. Because of this, the organization of the ministry is in a state of flux, and a more detailed discussion of its programs and organizations will not be provided. The following list of its major sections, before the reform started, provides some notion of the scope of activities covered:

1. Section of National Insurance.

2. Council of the Federal Fund for Agriculture.

3. National Advisory Council for Agriculture.

4. Commission for Planning Agricultural Policy.

5. Commission for the Interchange and coordination of International Technical Assistance. Credit.

6. Coordinating Commission for Agricultural

7. Department of Agricultural Research and Experimentation.

8. Department of Agricultural Promotion.

9. Department of Economics.

10. Department of Agricultural Inspection and Control.

11. Department of Renewable National Resources.

12. Superintendency of Agricultural and Veterinary Education.

13. Department of Indian Welfare.

14. Agricultural Information Service.

15. Meteorological Service. 
other entities directed by the ministry included the National Bank for Cooperative Credit and the Superintendency for Fisheries Development.

The state Secretariats of Agriculture are generally organized somewhat along the lines of the federal ministry. In most cases they are responsible for the research supported by the state governments, conduct programs of fomento, and provide other services to agriculture. Their organization varies by state, and ranges from rather large organizations, such as in são Paulo, to small organizations, such as in Mato Grosso.

In general the powers of the secretariats are declining. The process of attrition which took place at the national level has taken place at the state level. New entities have been formed, and successive functions transferred to them. The strongest state secretariat by far is in são paulo. which generally has a larger budget than the federal ministry.

\section{INDA and IBRA}

These two organs were created after the revolution of 1964 , in part to replace the demoralized agrarian reform agency and in part to provide more assistance to agriculture. They receive substantial resources from the federal government--channeled to them as a fixed percentage of the national budget.

The National Institute of Agricultural Development (INDA) has the responsibility for fostering development in rural areas. Part of its activities are of an extension nature; and to implement these activities, it provides resources to ABCAR, the federal extension agency. In addition to these activities, it plans to do a great deal of work with cooperatives.

The Brazilian Institute of Agrarian Reform (IBRA) replaced the former agrarian reform agency. Its program is nation-wide in scope. It has conducted a cadastral survey, re-appraised land and collected land taxes, and delineated certain priority areas for agrarian reform. This reform will deal with both the minifindio problem and the latiflindio problem. The large land holders will be compensated in money and government bonds. 
Both of these organizations are comparatively new, and it is difficult to evaluate the programs they are carrying out. INDA involves considerable duplication of the work of other organizations, although it appears to be delegating its work where possible. IBRA suffers the political difficulties of any agrarian reform agency.

\section{CNPq (The National Research Council)}

CNPq is an independent statutory body directly responsible to the president of the republic. It was founded in 1951, and in $1965 / 1966$ had a regular budget of $\$ 3,350,000$. In addition, some $\$ 6,000,000$ was made available for staffing and other administrative costs. The Ford and Rockefeller foundations have provided assistance over time, and an IDB loan of U.S.\$4 million has been received for equipment.

CNPq was created to stimulate and promote the development of scientific and technological research in all fields. It carries out its program by awarding financial grants-in-aid, by fellowships, and by the creation of research institutes in the areas needed. It also advises on the formulation and execution of scientific policy.

Public Law no. 4533 revitalized CNPq and gave it much broader authority. It brought representatives of two more federal agencies into the council (Ministry of Health and BNDE) and authorized the council to set up those special-purpose committees and commissions which it deems necessary without having to submit recommendations for presidential action, as was the case in the past. It authorized CNPq to create new research institutes and scientific centers as needed.

The breakdown of the 1965-1966 budget was as follows :

U.S. Dollars

Agronomical Research Biological Research Physics Research Geological Research Mathematics Research Chemical Research
218,850

750,000

687,500

300,000

143,750

375,000 
Technological Research

Technical sector

Supplement to the Biennium Plan

Specialized Institutes
406,250

86,250

100,000

$\frac{1,083,125}{4,169,375}$

As can be seen, only some 5 percent of the total budget goes for agronomical research. This is in part a reflection of the fact that agriculture has other sources of research funds.

Recently, CNPq has been given responsibility for bringing back to Brazil those technicians with advanced training who are working abroad. For this purpose it has been given funds to pay salary supplements and to provide the resources necessary to conduct effective resource programs.

CNPg is also attempting to stimulate research in the agricultural colleges and universities. This program can make a significant contribution to strengthening the colleges of agriculture and to broadening the research base within the country.

\section{CAPES (Council for Advanced Training of University-Level Personnel)}

This organization is under the Ministry of Education. It was founded in 1951, and in 1964 its budget was $\$ 1,500,000$. This was increased to $\$ 2,723,000$ in 1965 .

In 1964, the functions of the Supervisory Commission for Plans of Institutes and the original CAPES (National Campaign for the Advanced Training of University-Level Technicians) were combined into one organization, the present CAPES. The objectives of the new CAPES are: (1) to improve the qualifications of personnel engaged in teaching at university and college levels, under a priority system based on the requirements of the country's economic and social development; (2) to collaborate with the universities and colleges throughout the country; (3) to support centers of advanced research and training; (4) to coordinate national plans for the expansion of enrollments in areas of greater demand, without infringing upon the autonomy of the universities; (5) to conduct surveys, studies, and research 
on problems within the scope of the agency; (6) to administer grants offered by the Brazilian government to foreign students in graduate and postgraduate courses in Brazil.

CAPES disburses loans from the IDB and has received support from the Ford Foundation. The administration of the scholarship programs of CAPEs cooperates with governmental and private institutions for the selection of candidates. The section of documentation and statistics maintains records of advanced training and qualified professional personnel in Brazil.

Since its inception CAPES has done a creditable job of promoting scientific and technical postgraduate education in Brazil. It has sent a good number of qualified young Brazilian scientists abroad for specialized training in a variety of scientific and technical fields. Even though the primary responsibility of CAPES is the training of teachers, it has provided assistance for many persons who have been trained for basically scientific careers.

\section{Other Governmental Entities}

There are a number of important commodity organizations in Brazil, as well as entities with specific agricultural objectives. Among the more important of these are the following.

\section{Brazilian Institute of Coffee (IBC)}

This organization is under the Ministry of Finance and its administrative board contains representatives of coffee growers, traders, and state governments. The organization has substantial resources and presently is directing considerable effort to improving the quality of coffee. It also has underway a comprehensive plan for the diversification of farm operations by coffee producers. The emphasis is on improving varieties in the bestsuited production areas and on developing the necessary marketing facilities and services, through cooperatives, to support the diversification program. In recent years the IBC has financed a considerable amount of research. 
Institute of Sugar and Alcohol (IAA)

This organization is responsible to the president, and its administrative board includes representatives of the Bank of Brazil, the Ministries of Agriculture, Finance, Labor, and Public Works, and the sugar industry. Its basic function is to serve the industry. The program is substantially smaller than that of the IBC.

National Superintendency for Food Supply (SUNAB)

This organization is also under the president and is responsible for the coordination of national food supplies. In the past it has set retail food prices, sometimes under the misguided belief that it can control inflation. It has from time to time created considerable chaos in local markets. Through attempts to "help" consumers by lowering food prices, it quite frequently succeeds in driving practically all of some products from the market and in discouraging agricultural production:

In times of shortage SUNAB mobilizes resources to bring supplies from other areas. It has periodically attempted to force producers and middlemen to supply more produce to the market, sometimes by outright requisition.

\section{CEPLAC}

Although discussed earlier, this organization bears mentioning again because of the rather broad programs it carries out. It conducts research and extension, but also facilitates the marketing of cocoa. Budget and support have been strong so far, and the agency is dealing with a part of the Brazilian rural sector that has been largely bypassed by other agencies.

Executive Group for the Rationalization of Coffee Production (GERCA)

This is an important action agency in Brazil at the present time. It is subordinate to the Ministry of Trade and Industry, with its headquarters located in the Brazilian Institute of Coffee. Plans call for the removal of 2 billion old and low-yield coffee trees, with the release of a total area of 2.42 million hectares. It is hoped that a small 
part of the area can be replanted with 500 million coffee trees of high-yield varieties, thereby releasing the remaining area for production of corn, grasses, castor beans, peanuts, sesame, soybeans, and forest and fruit trees.

Substantial progress is being made in this program, and large areas of coffee have been released for food production. The impact of this program could be great. In addition to the activities described above, the agency also finances considerable research by other institutions.

\section{Support for Colonization}

Although spontaneous settlement is extensive and probably increasing rapidly, planned colonization in Brazil has been minimal. There has been a national organization with the responsibility for colonization, the National Institute of Immigration and Colonization, but it has had neither the funds nor the organization to carry out an effective program.

The original idea was that agricultural colonies would be established by federal decree throughout the country. However, most of those that were established have not been successful, in large part because the colonists were often left without guidance and financial assistance. Furthermore, many colonies were established on land unsuitable for agriculture; and areas allocated per settler were frequently too small to support a family, or to develop an economically viable farm.

In 1954 credit for colonization was provided by law through the Carteira de colonização of the Bank of Brazil. Since this branch did not function prior to 1961, its obligations during 1954-1961 were assumed by CREAI of the Bank of Brazil. Loans were granted on a small scale and only for the purpose of obtaining land.

Most state governments have their own departments of colonization. Some of these departments have been functioning for several decades, particularly in the states along the coast. The area of land granted each colonist has usually been between 20 and 30 hectares. 
A colonization program on the largest scale since projects began is under way in western Maranhão, where SUDENE intends to settle 25,000 families. An elaborate scheme groups 50-hectare lots around centers of supply and rural industry. It is reported that this program is having difficulties, however.

Most of the public lands in Brazil are held by the states, although some is still in the hands of the federal government. States owning appreciable amounts of land have been promoting land sales by their colonization agencies, partly to stimulate settlement and partly to obtain revenue. Large areas of these new lands have been bought by persons whose prime interests are speculation and protection against inflation.

The greatest amount of new settlement in Brazil has been accomplished spontaneously. Year by year, thousands of settlers have been moving onto the unused lands, clearing the natural vegetation, and establishing farms.

Only limited study of this spontaneous settlement has been made. However, as has been pointed out, it appears that many of these new units are quite small. This suggests the possibility of a very serious adjustment problem in the future, since the units will most likely have to be recombined into larger, more viable units, and the excess labor will have to find employment elsewhere.

As a minimum, it would seem that some plan should be developed so that the original land holdings are of a viable economic size, at least within the near future. Colonization programs that go beyond this tend to be quite expensive. However, some attempt at alleviating the future adjustment problems would appear to be important.

\section{THE GENERAL CHARACTER OF ADMINISTRATION}

A serious problem in Brazil is the general administrative organization in governmental agencies. This has a number of aspects. First, part-time employment was instituted in government entities as a means of spreading the work and providing job opportunities. This arrangement is a serious obstacle 
to making government institutions effective. It has led to multiple job holding on the part of most qualified people.

The problem of part-time employment has been compounded by the fragmentation of institutions working in a given area. From time to time autonomous agencies are set up to circumvent the problems of the established ministries , secretariats, and other institutions. This fragmentation has created much administrative confusion, spread the scarce administrative and technical talent even thinner, and resulted in much duplication of effort. The number of units making up the total governmental service sector is great, and only recently has an attempt been made to identify them and indicate how they fit together. This proliferation is complicated still further by the large number of agencies which have to report directly to the president.

\section{REGIONAL DEVELOPMENT AGENCIES}

In the last 20 years a number of agencies have been created to promote economic development in specific regions. These are:

1. Commission of the Valley of the São Francisco (CVSF).

2. Superintendency of the Plan of Economic valuation of the Amazon (SPVEA).

3. Superintendency of the Plan of Valuation of the southwest Frontier (SPVF).

4. Superintendency for the Development of the Northeast (SUDENE).

5. Service of the Valley of the Paraíba.

These agencies vary in the attention they give to the agricultural sector. A brief description is provided of the major organizations in the recent past in order to provide some notion of the scope of their efforts. 
Commission of the Valley of the são Francisco (CVSF)

The commission was established in 1948, with headquarters in Rio de Janeiro. The São Francisco River rises in Minas Gerais, in the region of Belo Horizonte, flows north through Bahia, then east to the Atlantic, forming part of the boundaries of Pernambuco, Alagoas, and Sergipe. Some of its tributaries reach into a small part of Goiss, in the vicinity of Brazília.

The total area administered by CVSF is 620,000 sq. $\mathrm{km}$. Its program includes regulation of stream flow, flood control, development of hydro-power potentialities, large-scale irrigation, improvement of transportation and communications by both river and road, and improvement of production and social services.

CVSF has received 1 percent of federal revenues. In 1960 this amounted to U.S.\$10,000,000. Expenditures for 1956-1960 were as follows:

\section{Project $\quad$ Percent of Budget}

Canals

Improved Electricity Supply

Transportation

Improved Production Methods

Health

Irrigation, Drainage

Study, Research

Education
34.7

16.8

16.3

13.0

11.7

4.0

1.8

$\frac{1.7}{100.0}$

Plans for 1961-1965 provided for construction of an additional dam, large irrigation systems in the central portion of the valley, and reclamation of flooded land in the lower delta. The organization was recently renamed as a superintendency, but its basic objectives remain the same. 
The agricultural technical staff of CVsF recently included 45 agronomos, 23 veterinarians, and 14 agricultural technicians. Objectives have included the improvement and increased production of rice, onions, grapes, figs, cotton, and oil crops. A pilot project for rural electrification is functioning in Itacuruba-Rodelas, the result of an agreement between CVSF and the,OAS. The total impact of the CVSF on the agriculture of the region has not been great, however.

Superintendency of the Plan of Economic Valuation of the Amazon (SPVEA)

This superintendency was established in 1953 and began work in 1955. Its headquarters are at Belem. The region under its administration is called "Legal Amazonica." It comprises all the North, the part of Mato Grosso north of $16^{\circ} \mathrm{s}$. latitude, the part of Goiss north of $13^{\circ} \mathrm{s}$. and the part of Maranhão west of $44^{\circ} \mathrm{W}$. longitude.

The duties of SPVEA were to stimulate production of agricultural and extractive products; to encourage cattle breeding, industrial development, and mining; and to improve market conditions. It has been allotted 3 percent of the revenues from federal taxes; 3 percent of the revenue of the states, territories, and municípios within its sphere; and the income it generates for itself from its own operations and extension of credit. The full allotment generally has not been paid, however. The federal contribution, for example, has usually been less than 2 percent.

SPVEA was originally set up for a 20-year period, 1953 to 1973. By 1962 the agency should have been in its second five-year plan. However, the first five-year plan was never approved by the federal government, and political changes in recent years delayed the development of a strong program even more.

Separate, but also under the supervision of SPVEA, was the organization Rodobras, which was formed to build the road from Belem to Brasilia. Some 65 percent of the funds for building this road was withdrawn from functioning Amazon projects. 
starting in 1953 there was a mission from FAO to advise SPVEA on problems pertaining to forestry and agricultural production. Programs have included training Brazilian personnel in a model sawmill and in logging and silviculture, a survey of about 20 million hectares of Amazon forests, a study of forest policy, and outlines for a forest research center. Other projects have included soil surveys, a study of animal diseases, studies of crop production and the rural economy, and an examination of fisheries.

Geologists from UNESCO also provided SPVEA with technical assistance for several years. The Escritorio Técnico de Agricultura (ETA), a joint Brazilian and U.S. technical agency, supervised training and extension work in rubber cultivation and distribution of improved hevea plants.

In early 1967, SPVEA was reorganized and given a new name and, supposedly, increased resources. The objective was to make development in the region proceed at a rate of around 9 percent per year. A complementary policy was to declare the port of Manaus a free port, exempting it from duties and tariffs.

Superintendency for Economic Valuation of the Southwest Frontier (SPVF)

Although created in 1956, the general directives of this superintendency were not drawn up until 1961. Its headquarters are in Pôrto Alegre. The zone administered by SPVF includes some munícipios in Mato Grosso and Parana, but the majority are in santa Catarina and Rio Grande do Sul. SPVF has outlined priorities for projects in each state:

\section{Mato Grosso}

1. Electrification

2. Transport, Communications

3. Health

4. Agriculture
Santa Catarina and Parans

1. Electrification

2. Health

3. Agriculture

4. Transport, Communications
Rio Grande do Sul

1. Agriculture

2. Health

3. Electrification

4. Transport, Communications 
The proposed budget for 1964 was U.S.\$26,700,000. It was to be allocated as follows:

Project 8 of Budget state 8 of Budget

Land

Improvement

Social

Improvement

Administrative Improvement

Reserve
45

33

Mato

Grosso

Parank

Santa

16 Catarina

Rio Grande

do Sul
24

20

16

40

So far the activities of this superintendency have been rather limited.

Superintendency for the Development of the Northeast (SUDENE)

SUDENE was established in 1959, and its headquarters are in Recife. This superintendency represents the third step in government planning for the Northeast, and succeeds the Development Council of the Northeast. The area in which suDENE operates includes the Northeast as defined by the IBGE, plus Sergipe, Bahia, and a small part of Minas Gerais. It includes the Poligano das Secas (the "Dry Polygon").

The region administered by sUDENE has an area of $1.6 \mathrm{milition} \mathrm{sq.} \mathrm{km}$. and a population of about 25 million persons. Mean annual income per capita in the region is barely U.S.\$100. Population is concentrated in the humid coastal area, where agriculture is specialized in sugarcane production. Production of foodstuffs is insufficient and there are chronic shortages. Droughts are a serious problem in the region. As population has increased, the consequences of the droughts have become increasingly serious.

Because of the importance of this region as a critical poverty area, 1 and because of the fact that SUDENE has been one of the most intensive development 
efforts in Brazil, its program will be examined in more detail than those of the other development agencies. SUDENE has been quite controversial within Brazil, and the subject of considerable scrutiny from without. Its prograns have had some measure of success, since in recent years per capita incomes in the region have been rising relative to the rest of the country. jectives :

SUDENE'S plans incorporate four principal ob-

1. To intensify industrial investment, aiming at the creation of centers for manufacturing.

2. To transform the agrarian structure of the humid coastal area by stimulating a more intensive utilization of land for sugarcane, thus making land available for food production.

3. To institute a progressive change in the economy of the semi-arid zones.

4. To provide room for the population increase by developing the humid regions of Maranhão and south Bahia.

SUDENE has concentrated on expanding the basic social capital, on the assumption that this would provide a basis for attracting external private and social capital. As a result of this program, the traditional exit of savings from the region has stopped and capital from other regions of the country is being attracted. A major factor behind the flow of capital to the Northeast has been legislation which permits companies in the South to invest some part of what would be their federal income taxes in industrial projects in the Northeast. These projects have to be approved by SUDENE and are evaluated in terms of their contribution to the region. The impact of this program appears to be very sizable.

Resources mobilized by SUDENE for development have come from three sources: (1) the private sector, through deductions on income taxes and bank financing; (2) the public sector, through the national treasury; and ( 3 ) external grants or donations. SUDENE is supposed to receive from the national treasury a minimum of 2 percent of the federal tax revenue. Data on the resources mobilized from the 
various sources for investment during the first five years are presented in Table 98.

Data on the sectoral application of resources from the national treasury are given in Table 99. The total contribution from the treasury fell off somewhat in 1964 , but increased substantially in 1965. This increase in 1965 was possible partly because of a basic shift in policy by the organization. From being a strong action agency it shifted to an increasing delegation of activities to other entities. The goal now is to remove the execution of projects from SUDENE's hands, and depend more on the contracting of services with local agencies. In 1965, 74 percent of the activities were contracted out, and it is expected that this can be increased to 85 percent in the near future.

Further insights into the nature of the sUDENE program can be found in Table 100, which provides indexes of the public investment realized in the area, broken down on a different classification. The average rate of increase in the period covered was 9.7 percent per year--approximately double that in the rest of the country. This represents a considerable effort to eliminate the regional disparity and disequilibrium which exists.

The largest increase in investments was for electrical energy. There was also a significant increase in the direct participation of government in industrial activity. The increase in education went in large part to higher education, since SUDENE has placed a great deal of emphasis on developing a technical cadre.

Low priority has been given to agriculture and railroads. The reason given for this is that investments in these sectors have a low productivity.

The five-year plan for 1961-1965 contained the following directives for the agrarian sector:

1. To open large settlement areas. The first project for the settlement of 25,000 families in Maranhăo began in 1963. A similar plan was considered for coastal land of southern Bahia.

2. To change the agrarian structure of the humid area of the Zone da Mata. SuDENE proposed to 


\section{TABLE 98}

Capital-Formation Resources Mobilized

by SUDENE, 1960-1965

(milion NCr\$, 1965)

\begin{tabular}{|c|c|c|c|c|c|}
\hline Year & $\begin{array}{l}\text { Private } \\
\text { Sector }\end{array}$ & $\begin{array}{c}\text { Origin of Resources } \\
\text { National } \\
\text { Treasury }\end{array}$ & External & Total & $\begin{array}{l}\text { Percentage } \\
\text { Variation }\end{array}$ \\
\hline 1960 & 99.4 & - & - & 99.4 & - \\
\hline 1961 & 85.7 & - & 21.3 & 107.0 & +7.6 \\
\hline 1962 & 90.6 & 31.2 & 33.0 & 154.8 & +44.7 \\
\hline 1963 & 122.4 & 51.7 & 144.4 & 318.5 & +105.7 \\
\hline 1964 & 213.8 & 49.2 & 153.8 & 416.8 & +30.9 \\
\hline 1965 & 143.3 & 74.4 & $69: 0$ & 286.7 & -31.2 \\
\hline Total & 755.2 & 206.5 & 421.5 & $1,383.2$ & - \\
\hline
\end{tabular}

Deflator: General Index of Prices, FGV.

Source: SUDENE, Relatório das Atividades. da SUDENE em 1965 (Recife, 1966). 
TABLE 99

Sectoral Distribution by SUDENE

of Resources from National

Treasury, 1962-1965

(million NCr\$; 1965)

\begin{tabular}{lrrrrr}
\hline \multicolumn{1}{c}{ Sector } & 1962 & 1963 & 1964 & 1965 & \multicolumn{1}{c}{$\begin{array}{l}1962 / \\
1965\end{array}$} \\
\hline Infrastructure & 23.8 & 34.7 & 31.0 & 49.7 & 139.2 \\
$\quad$ Energy & 10.7 & 20.1 & 18.4 & 24.3 & 73.5 \\
\multicolumn{1}{c}{ Transport } & 12.4 & 8.5 & 6.2 & 15.0 & 42.1 \\
$\quad$ Basic Sanitation & 0.7 & 6.1 & 6.4 & 10.4 & 23.6 \\
Natural Resources & 1.5 & 3.7 & 6.6 & 9.0 & 20.8 \\
Human Resources & 0.2 & 2.4 & 2.7 & 4.4 & 9.7 \\
Agriculture, supply & 3.5 & 8.0 & 6.0 & 5.0 & 22.5 \\
Fishing & -- & -- & -- & 1.9 & 1.9 \\
Colonization & 1.7 & 2.4 & 1.5 & 2.5 & 8.1 \\
Industry & 0.5 & 0.5 & 1.4 & 1.9 & 4.3 \\
\hline Total & 31.2 & 51.7 & 49.2 & 74.4 & 206.5 \\
\hline
\end{tabular}

Source: SUDENE, Relatório Das Atividades da SUDENE em I965. 
TABLE 100

Indexes of Public Investment Realized

in the Northeast, 1960-1964

\begin{tabular}{|c|c|c|c|c|c|}
\hline & 1960 & 1961 & $\begin{array}{l}\text { Year } \\
1962\end{array}$ & 1963 & 1964 \\
\hline \multicolumn{6}{|l|}{ Activity } \\
\hline $\begin{array}{l}\text { Agriculture, Fishing } \\
\text { Industry, Mining } \\
\text { Electrical Energy } \\
\text { Water Supply, Sanitation } \\
\text { Transport, Communication, } \\
\text { Storage } \\
\text { Roads } \\
\text { Railroads, Ports } \\
\text { General Administration } \\
\text { Education } \\
\text { Health }\end{array}$ & $\begin{array}{l}100.0 \\
100 \cdot 0 \\
100 \cdot 0 \\
100 \cdot 0 \\
100 \cdot 0 \\
100 \cdot 0 \\
100 \cdot 0 \\
100 \cdot 0 \\
100.0 \\
100 \cdot 0\end{array}$ & $\begin{array}{r}88.5 \\
130.5 \\
165.8 \\
74.3 \\
63.4 \\
137.1 \\
83.5 \\
105.6 \\
153.0 \\
83.9\end{array}$ & $\begin{array}{r}51.8 \\
146 \cdot 3 \\
419.5 \\
74.0 \\
106.2 \\
147.8 \\
72.8 \\
135.6 \\
189.3 \\
72.2\end{array}$ & $\begin{array}{r}124.2 \\
173.7 \\
269.7 \\
75.5 \\
71.4 \\
110.0 \\
50.7 \\
126.9 \\
213.5 \\
44.1\end{array}$ & $\begin{array}{r}100.2 \\
174.7 \\
601.2 \\
98.0 \\
66.5 \\
106.6 \\
20.8 \\
147.2 \\
212.4 \\
46.9\end{array}$ \\
\hline \multicolumn{6}{|l|}{ Organism } \\
\hline $\begin{array}{l}\text { Firma } \\
\text { Autarquias } \\
\text { Central Government }\end{array}$ & $\begin{array}{l}100.0 \\
100.0 \\
100.0\end{array}$ & $\begin{array}{l}118 \cdot 1 \\
102 \cdot 6 \\
101.2\end{array}$ & $\begin{array}{l}157.1 \\
121 \cdot 8 \\
120.2\end{array}$ & $\begin{array}{l}165.1 \\
107.4 \\
121.0\end{array}$ & $\begin{array}{r}192.8 \\
99.0 \\
147.1\end{array}$ \\
\hline General Total & 100.0 & 108.4 & 135.2 & 132.2 & 132.4 \\
\hline
\end{tabular}

apublic firms such as Petrobras.

Source: SUDENE, Relatório dag Atividades da suDENE em 1965. 
promote irrigation and partial mechanization of sugarcane growing in this area. It was expected that this would release land for food production. The proposed project involved the irrigation of 100,000 hectares of canefields, and the settlement of 50,000 families on land previously cultivated for cane.

3. To irrigate some parts of the semi-arid zone and establish a type of farming unaffected by drought. This project involved irrigation of 89,000 hectares with water supplies already dammed but unused.

4. The integrated development of the main valleys in the region. A series of integrated studies of water resources, soil, subsoil, vegetation, and agricultural potential were begun. Such a project for the lower-middle são Francisco region was being carried out with the assistance of the U.N. Special Fund, which granted U.S.\$974,200 for a five-year survey program. The Parafba and Jaguaribe valleys were to be covered by similar systematic studies. In the case of the Jaguaribe, SUDENE was to obtain broad technical cooperation from the government of France.

In addition to these programs, considerable attention has been given to the problem of marketing, on the premise that the principal reason for the high cost of food is the distribution system.

External aid to the region has been rather broad-based. The U.S. government has taken considerable interest in the Northeast, as have other countries. Data on the amounts of external funds supplied to SUDENE during its first five years of existence are given in Table 101. The largest contributor was the United States, although there was considerable fluctuation from year to year.

The biggest source of outside help in 1965 was West Germany. Of the total, DM43 million went to promote small industries and develop the fishing industry, DM40 million went for hydroelectric power, and DMI.l million went to the state of Alagoas.

In the second place was the United States, through USAID, which gave U.S. $\$ 8,900$ thous and and $N C r \$ 2,300$ thousand in the form of loans and U.S. U.S. $\$ 1,855$ thousand and NCr\$4,196 thous and in the 
TABLE 101

External Funds Supplied to SUDENE, 1961-1964

(million NCr\$, 1965)

\begin{tabular}{lcccr}
\hline Year & USAID & BID & $\begin{array}{c}\text { Origin of Funds } \\
\text { Fundo Alemão }\end{array}$ & Total \\
\hline 1961 & -- & 21.3 & -- & 21.3 \\
1962 & 33.0 & -- & -- & 33.0 \\
1963 & 82.7 & 61.7 & -- & 144.4 \\
1964 & 153.8 & -- & -- & 153.8 \\
1965 & 25.9 & 5.2 & 37.9 & 69.0 \\
\hline Total & 295.4 & $\mathbf{8 8 . 2}$ & 37.9 & 421.5 \\
\hline
\end{tabular}

Deflated by General Index of Prices, FGV.

Source: SUDENE, Relatório das Atividades da SUDENE em 1965. 
form of grants. Inter-American Development Bank

(IDB) gave U.S.\$2.9 miliion, of which U.S.\$2.7 million was destined to agricultural cooperatives. The remaining U.S. $\$ 200,000$ was given to the mining company of Bahia.

The USAID monies were spent as follows:

$$
\begin{gathered}
\text { (thousand } \\
\text { NCr\$) }
\end{gathered} \begin{gathered}
\text { (thousand } \\
\text { U.S.\$) }
\end{gathered}
$$

Agricultural Teaching,

Univ. of Ceard

200

400

Federation of Rural

Workerg

Electrification of

Rural Communities

Training of Industrial

Labor

Elementary Education,

R.G. do Norte 1,000

Adult Education,

Agricultural Colleges $\quad 500$

Training Center of

the Northeast

$$
\operatorname{Cr} \$ \frac{200}{3,446}
$$

$\overline{400}$

The remainder went for various industrialization and infrastructure programs.

The sectoral allocation of all external resources in 1965 is presented in Table 102.

Specific technical assistance programs in 1965 were as follows:

1. French government--20 technicians, a study of the integrated development of the Jaguaribe Valley.

2. FAO--technical and financial, study of the viability of large-scale irrigation in the lowermiddle São Francisco region. 
TABLE 102

Sectoral Allocation of External Resources, $1965^{a}$

\begin{tabular}{lrc}
\hline \multicolumn{1}{c}{ Sector } & $\mathrm{NCr} \$ 1,000^{\mathrm{b}}$ & U.S.\$1,000 \\
\hline Education & 8,792 & -- \\
Housing & 259 & -- \\
Water Supply & 179 & 3,060 \\
Energy & 408 & 2,802 \\
Transport & 400 & 38 \\
Agriculture, Supply & 288 & -- \\
Natural Resources & 246 & -- \\
Industry & 2,000 & -- \\
Public Administration & 274 & -- \\
\multicolumn{1}{c}{ Total } & 12,846 & 5,900 \\
\hline
\end{tabular}

amoney actually spent in the region.

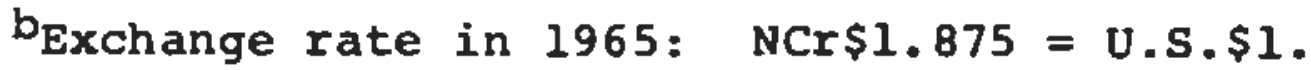

Source: SUDENE, Relatório das Atividades da SUDENE em 1965. 
3. Israe 1--production of selected hybrid seed corn and the development of sorghum.

4. Japan--training of textile technicians.

5. USAID--various areas, including energy, transport, and basic sanitation.

6. U.N.--5 technicians, cotton genetics and control of cotton diseases, soil survey, analysis of economic planning, weather forecasting.

Next to SUDENE, the most important institution in the region is the Banco do Nordeste do Brasil, headquartered at Fortaleza, Ceark. This is the regional development bank.

Service of the Valley of the Parafba (SVP)

SVP is administered by the Department of water and Electric Energy of são Paulo. Although the Parafba Valley extends from são Paulo into Rio de Janeiro and Minas Gerais, the SVP has so far been concerned only with the state of são Paulo.

Most of the studies made so far have been of natural resources. One irrigation project has been carried out, and an area of 50,000 hectares in the Una River basin was selected for a pilot project, where detailed studies are made of natural resources and of the economic activities of the population. An effort is being made to raise the standard of living by educational and sanitary improvements and instruction in agricultural practices.

\section{BUDGET SUPPORT FOR AGRICULTURE}

Budget support for agriculture at the federal level has been provided through numerous agencies. A small amount of resources have been provided through the National Development Bank, and a substantial sum has come from foreign sources.

\section{Federal Government}

Budget support through the Ministry of Agriculture has been relatively small in the postwar period. Data on the flve-year period 1960-1964 are provided in Table 103. These data.include both the 
capital and current account budgets. The fraction for investment, however, is relatively small.

TABLE 103

Budget Resources of the Ministry of Agriculture, 1960-1964

\begin{tabular}{lccc}
\hline Year & $\begin{array}{c}\text { Budget of } \\
\text { Budget } \\
\text { (billion Cr\$) }\end{array}$ & $\begin{array}{c}\text { Agriculture } \\
\text { Ministry of } \\
\text { (bilion Cr\$) }\end{array}$ & $\begin{array}{c}\text { Percent } \\
\text { of Total }\end{array}$ \\
\hline 1960 & 194 & 12 & 5.9 \\
1961 & 302 & 15 & 4.8 \\
1962 & 572 & 22 & 3.9 \\
1963 & 1,023 & 45 & 4.4 \\
1964 & 2,110 & 122 & 5.7 \\
\hline
\end{tabular}

Source: Anuário Estatístico do Brasil (Rio de Janeiro: IBGE, various issues).

The operating expenses of the Ministry of Agriculture, compared with the total operating expenses of the government, are presented for the postwar period in Table 104. These expenditures increased somewhat in the immediate postwar period, held relatively constant in percentage terms through 1957 (with variations), and then declined thlough 1961. They increased through 1964 , and dipped off again in 1965. In any case, they have remained a fairly small part of the total budget.

These data are somewhat misleading, however. Support to agriculture comes from many other agencies of the government. This is in part a natural phenomenon, but in large part reflects the tendency to create new governmental organs in order to circumvent either vested interests in existing organizations and institutions, or legislative restrictions imposed by previous laws. 
TABLE 104

Expenses Realized by the Ministry of Agricul ture, 1944-1965

(thousand NCr\$)

\begin{tabular}{lcc}
\hline Year & Realized Expense & $\begin{array}{c}\text { Percent of } \\
\text { Total Expenses }\end{array}$ \\
\hline 1944 & 216 & 2.57 \\
1945 & 298 & 2.75 \\
1946 & 444 & 3.13 \\
1947 & 554 & 4.13 \\
1948 & 659 & 4.19 \\
1949 & 942 & 4.55 \\
1950 & 1,066 & 4.51 \\
1951 & 1,001 & 4.07 \\
1952 & 1,276 & 4.48 \\
1953 & 1,971 & 4.93 \\
1954 & 2,356 & 4.78 \\
1955 & 3,159 & 4.99 \\
1956 & 3,263 & 3.05 \\
1957 & 5,371 & 4.52 \\
1958 & 6,173 & 4.16 \\
1959 & 7,491 & 4.07 \\
1960 & 10,273 & 3.88 \\
1961 & 9,501 & 2.26 \\
1962 & 18,050 & 2.48 \\
1963 & 35,462 & 2.77 \\
1964 & 87,088 & 3.15 \\
1965 & 124,134 & 2.81 \\
\hline
\end{tabular}

Source: Anuario Estatístico do Brasil (Rio de Janeiro: IBGE, various issues). 
Some insight into the magnitude and source of funds from other sources can be obtained from Table 105, which indicates the various sources of federal funds and their proposed application for the year 1966. Data in the last column indicates that only 52 percent of the budget for agriculture comes from the Ministry of Agriculture. Other major sources are the Ministry of Transportation and Public Works and the presidential budget. Presumably, the budget allocation from the former represents an attempt to allocate the transportation budget among sectors.

It is interesting to note that the largest single item is promotion and extension. The second largest item is agrarian reform, although it is doubtful whether these funds were actually expended; and the next (ignoring administrative expenses) is agricultural engineering.

An important component of the budget for agriculture appears to be left out in this budget breakdown. Most of the colleges of agriculture are financed through the Ministry of Education and Culture, yet the amounts indicated in this table do not reflect the resources that would be involved in these operations. Similarly, the budget for the Ministry of Agriculture does not appear to reflect the resources used in supporting the schools of agriculture that were operated by this ministry.

The Development Bank

The low priority given to agriculture in the postwar industrialization period is indicated in part by the small proportion of funds allocated to agriculture in the activities of the National Development Bank (BNDE). Summary data on the allocation of funds during the first 10 years of the bank's existence are presented in Table 106. In the years 1952 to 1962 only 4 percent of the bank's local currency loans went to the agricultural sector, and 1.7 percent of its foreign exchange loans were made available to agriculture.

Foreign Aid and Loans

Substantial support for the agricultural sector has come from external sources in recent years. Although an accurate estimate of these funds is difficult, data are presented here which provide a 
TABLE 105

Federal Budget for Mgriculture, 1966

(thougand NCr\$)

\begin{tabular}{|c|c|c|c|c|c|c|c|c|c|c|c|c|c|c|}
\hline $\begin{array}{l}\text { Covt. } \\
\text { Organ }\end{array}$ & Admin. & $\begin{array}{l}\text { Regearch, } \\
\text { Technologi- } \\
\text { cal Exper- } \\
\text { lmentation }\end{array}$ & $\begin{array}{l}\text { Promo- } \\
\text { tion, Ag. } \\
\text { Bxtension }\end{array}$ & Ag. & $\begin{array}{l}\text { Mechant- } \\
\text { zation }\end{array}$ & $\begin{array}{l}\text { Disenge, } \\
\text { Pests }\end{array}$ & $\begin{array}{l}\text { Ag. In- } \\
\text { spection }\end{array}$ & $\begin{array}{l}\text { Renew- } \\
\text { able } \\
\text { Nat. Re- } \\
\text { oources }\end{array}$ & $\begin{array}{l}\text { Meteo- } \\
\text { rology, } \\
\text { climi- } \\
\text { tology }\end{array}$ & $\begin{array}{l}\text { Agrar- } \\
\text { lan Re- } \\
\text { form }\end{array}$ & Tratning & $\begin{array}{l}\text { Stud- } \\
\text { les. } \\
\text { Re- } \\
\text { Bearch }\end{array}$ & Tota 1 & Percent \\
\hline President & .02 & $=$ & .01 & - & - & .01 & $=$ & .21 & - & 51.53 & - & - & 51.58 & 19.0 \\
\hline $\begin{array}{l}\text { Coordination } \\
\text { of Regional } \\
\text { Organs }\end{array}$ & 1.47 & 1.54 & 12.14 & .64 & 2.17 & .48 & - & - & - & - & .01 & .60 & 19.15 & 6.8 \\
\hline $\begin{array}{l}\text { Min. of } \\
\text { Aeronautics }\end{array}$ & - & - & .04 & - & .04 & - & - & - & - & - & - & - & .08 & - \\
\hline $\begin{array}{l}\text { Min: of } \\
\text { Agricul ture }\end{array}$ & 32.50 & 21.73 & 58.07 & 4.00 & - & 5.91 & 5.18 & 14.0 & 1.64 & - & - & 3.97 & 147.00 & 52.0 \\
\hline $\begin{array}{l}\text { Min, of } \\
\text { Education, } \\
\text { culture }\end{array}$ & - & .22 & .18 & - & - & $=$ & $=$ & .01 & .06 & - & .21 & .08 & .76 & - \\
\hline Min, of War & - & - & .15 & - & - & - & - & $=$ & - & - & - & - & .15 & - \\
\hline $\begin{array}{l}\text { Hin. of Mines } \\
\text { and Energy }\end{array}$ & - & - & - & - & - & - & - & - & - & - & - & .05 & .05 & $=$ \\
\hline $\begin{array}{l}\text { Min. of } \\
\text { Trangporta- } \\
\text { tion and } \\
\text { Public Norks }\end{array}$ & 11.04 & - & 11.00 & 35.62 & - & - & - & 3.12 & - & - & .13 & 2.38 & 63.30 & 22.4 \\
\hline Total & 45.03 & 23.49 & 81.59 & 40.26 & 2.21 & 6.40 & 5.18 & $17 \cdot 34$ & 1.70 & 51.53 & .35 & 7.08 & 282.07 & 100.0 \\
\hline Percentage & 16.0 & 8.3 & 28.9 & 14.3 & .08 & 2.3 & 1.8 & 6.1 & 0.6 & 18.3 & 0.0 & 2.5 & - & - \\
\hline
\end{tabular}

Source: Ministry of Planning and General Coordination, orcamento Programa (1965). 
Percentage Allocation of Loans, by Sector, of the National Development Bank, $1952-1962$

\section{Local Currency Loans}

Transport

Electric Energy

Basic Industry

Agriculture

Foreign Exchange Loans

Transport

Electric Energy

Basic Industry 48.1

Agriculture

Source: Adapted from Werner Baer, Industrialization and Economic Development in Brazil (Homewood, I11.: Richard D. Irwin, Inc., 1965), P. 108 . 
TABLE 107

Distribution of Funds by Organization and Field, 1962-1965 (thousand 0.5.\$)

\begin{tabular}{|c|c|c|c|c|c|c|c|c|c|c|c|c|c|c|}
\hline & IDB & $\begin{array}{l}\text { World } \\
\text { Bank }\end{array}$ & Un: & ans & $\begin{array}{l}\text { US } \\
\text { AID }\end{array}$ & $\begin{array}{l}\text { US } \\
\text { NEC }\end{array}$ & $\begin{array}{l}\text { Matl. } \\
\text { Inst. } \\
\text { Bealth }\end{array}$ & $\begin{array}{l}\text { Natl. } \\
\text { sci. } \\
\text { Pound. }\end{array}$ & $\begin{array}{l}\text { Mili- } \\
\text { tary }\end{array}$ & USDA & Pord & $\begin{array}{l}\text { Kel- } \\
\text { logg }\end{array}$ & $\begin{array}{l}\text { Rocke- } \\
\text { feller }\end{array}$ & Total \\
\hline Agt. & 13,750 & & 3,323 & 191 & 11,808 & & & 411 & & 726 & 3.500 & & 337 & 34,072 \\
\hline oceanog. & & & 835 & & 90 & & & & & & 2 & & 548 & 1,475 \\
\hline Med. Biol. Sci. & & & 1,089 & & & 142 & 1,111 & 19 & 208 & & & 509 & 685 & 3,762 \\
\hline Dental Set. & & & 11 & & & & & & & & & 128 & & 135 \\
\hline Nath. & & & & & & & & 91 & 20 & & & & & 111 \\
\hline ches. & & & 4 & & & & & & 48 & & 490 & & 24 & 566 \\
\hline Bng. & & & 721 & & 1,760 & & & & & & 160 & & & 2,641 \\
\hline Phyaics & & & 22 & & 16 & 122 & & 101 & 213 & & 100 & & 1 & 575 \\
\hline Meteorology & & & 170 & & 38 & & & & & & & & & 200 \\
\hline Cecphys. & & & & & & & & & 20 & & & & & 20 \\
\hline Mat. Res. & & & 716 & & 76,622 & & & 155 & & & & & & 77,494 \\
\hline Ind. + Manpower & 2,650 & & 163 & & 244 & & & & & & . & & & 3.057 \\
\hline Porer & 41,900 & 79.500 & 2,571 & & 31.575 & & & & & & & & & 155,536 \\
\hline trang. & & & 34 & & 12,044 & & & & & & & & & 12,078 \\
\hline Boo. + Plan. & 340 & & 314 & 237 & 1,188 & & & & & & 1,172 & & 14 & 3.264 \\
\hline Pub. + Bus. Mdain. & & & $\mathbf{5}$ & & 5,852 & & & & & & 905 & & & 6.762 \\
\hline Ed. & 4,000 & & 1,519 & 4 & 3,761 & & & & & & 4.562 & & & 13,043 \\
\hline Sociology & & & 17 & 4 & 445 & & & & & & & & & 466 \\
\hline rotal & 62,640 & 79.500 & 11,514 & 436 & 145.443 & 264 & 1,111 & 777 & 509 & 726 & 10,891 & 637 & 1,609 & 313.974 \\
\hline
\end{tabular}

aloans and grants cobined.

Sore arounts include rears before 1962 or after 1965.

Due to rounding, coluing and rors may not add up to total.

Source: -science and Bratilian Developent, Part $I$ of a Repart of a workghop on Contributions of science and rechnólogy to Developent, Mpril 11-16, 1966, Itatifia, Braxil. Workshop vas under the auspices of the Matical pesearch council of Brasil and the 0.S. Bational ncadery of Sciences in cooperation uith usin. 
TABLE 108

Breakdown of Loans and Grants for Agriculture and Plant Sciences, 1962-1965 (thous and U.S.\$)

\begin{tabular}{|c|c|c|c|c|c|c|c|c|c|}
\hline & IDB & OAS & UN & USAID & USDA & NSF & Ford & $\begin{array}{l}\text { Rocke- } \\
\text { feller }\end{array}$ & Total \\
\hline $\begin{array}{l}\text { Land Reform, } \\
\text { Colonization }\end{array}$ & 2,000 & 6 & 277 & 194 & & & & & 2,427 \\
\hline $\begin{array}{l}\text { Machinery, } \\
\text { Equipment }\end{array}$ & 9,000 & & & & & & & & 9,000 \\
\hline $\begin{array}{l}\text { Development } \\
\text { Programs, } \\
\text { Productivity }\end{array}$ & 2,750 & & 63 & 1,910 & & & & & 4,723 \\
\hline $\begin{array}{l}\text { Extension, } \\
\text { Education, } \\
\text { Curriculum } \\
\text { Planning, } \\
\text { Related } \\
\text { Institutional } \\
\text { Development }\end{array}$ & & 186 & 2,844 & 9,210 & & & 2,795 & 41 & 15,076 \\
\hline
\end{tabular}




\begin{tabular}{|c|c|c|c|c|c|c|c|c|c|}
\hline & IDB & OAS & UN & USAID & USDA & NSF & Ford & $\begin{array}{l}\text { Rocke- } \\
\text { feller }\end{array}$ & Total \\
\hline $\begin{array}{l}\text { Research, } \\
\text { including } \\
\text { Materials } \\
\text { \& Equipment }\end{array}$ & & & 42 & & 726 & 411 & & 297 & 1,476 \\
\hline Tota1 & 13,750 & 192 & 3,323 & 11,808 & 726 & 411 & 3,500 & 338 & 31,978 \\
\hline
\end{tabular}

$a_{\text {Approximately. }}$

Source: "Science and Brazilian Development," Part I of a Report of a Workshop on Contributions of Science and Technology to Development, April 11-16, 1966, Itatiaia, Brazil. 
perspective on the share of outside funds received by agriculture, and the source and distribution of funds applied within the agricultural sector. 2

Only projects of the three major foundations-Kellogg, Ford, and Rockefeller--are included. The data refer to the period 1962-1965, although it was not always possible to determine the exact amounts of money spent during this specific period on the projects. In some cases the amount indicated includes years prior to 1962 , while in other cases it refers to years after 1965. However, the data should indicate fairly accurately where the emphasis lies in foreign aid. (Fellowship figures are not included for Fulbright, Rockefeller Foundation, some U.N. agencies, and the OAS. The latter organization spent $\$ 176,000$ in fellowships during 1963-1964.)

Table 107 shows the distribution of each organization's funds by field. The largest single recipient of outside funds was the power sector, which received more than twice as much as the secondplace sector, natural resources. Agriculture was in third place, but at a level only about one-fifth that of the power sector.

USAID has been the largest donor, contributing almost 50 percent of the total. Other major contributors have been the World Bank and the Inter-American Development Bank.

A further breakdown within the agriculture and plant sciences field is presented in Table 108 . Within this sector, IDB has provided the largest amount of resources, followed closely by USAID. The largest component of the funds--almost half--has gone for institutional development.

\section{AGRICULTURAL POLICY ${ }^{3}$}

Many aspects of agricultural policy have been implicit in previous discussions. These include the research and educational activities, the public investment programs, and the activities of the regional development agencies. In this section, attention is focused on those activities which are more explicitly considered to be agricultural policies. 
Brazilian agricultural policy has been of a rather fluid, shifting nature, and composed of numerous elements. Although it has probably had some positive effect on the agricultural sector, it has most likely had less effect than the set of general economic development policies followed, which had other primary objectives. Most notable anong these were the overvaluation of the currency and the prohibition or limitation of exports. The principal policy objective of the government prior to 1964 was rapid industrialization. The set of policies used to attain this, involving principally import-substitution industrialization, discriminated rather heavily against the agricultural sector. 4

In general the agricultural sector was sorely neglected prior to 1964. Such policy measures as were taken were in response to short-term supply crises, and were generally of a very short-run nature. They tended to rely on market incentives, although they exhibited an overriding concern that final prices to consumers not be raised.

Inefficiencies in the marketing system have long been considered one of the chief factors retarding the development of Brazilian agriculture. Arguments are made that a large fraction of the production is lost between the farmer and the consumer (estimates range as high as 33 percent), and that both the producer and consumer are exploited by the middleman. It is argued in the latter case that this exploitation prevents the price system from reflecting consumer demand to the producer.

This line of thought is still strong in Brazil, although it has (rightly) declined in prevalence in recent years. However, in the decade of the $1950^{\prime} \mathrm{s}$ it was the predominant interpretation of the agricultural problem. Hence, when a geries of food shortages, with rising food prices, occurred in the years 1951-1954, the government implemented measures to increase the construction of warehouses and storages, through both the formation of mixed companies (with public and private funds) and the granting of credit through the Development Bank for warehouse construction. Coincidentally, a massive road construction policy was being carried out. Total road mileage increased from $302,147 \mathrm{kilometers}$ in 1952 to 803,068 in 1965.5 
It is difficult to evaluate the impact of these programs on the agricultural sector. It seems clear that deficiencies in both the communication system and the transportation syatem could lead to aizable imperfections in the marketing system. This being the case, the increased road construction, and the corollary development of the trucking industry, surely led to improvements in the marketing system.

The degree to which middlemen were able to exploit monopoly positions for any length of time is much more questionable. The roving fleets of trucks were certainly able to reduce price differentials rather rapidly, and there seemed to be no obvious barriers to entry into the food distribution sector.

Smith has made one of the few in-depth atudies of the performance of the marketing system in Brazil.6 He gives special attention to the frontier area, where the case for monopoly exploitation geems especially likely. He concludes that although there were probably monopoly profits earned in the early years, these were rapidiy eliminated as new firms entered the industry. Moreover, he calculates marketing margins for rice, corn, and beans at several locations in the Central south, and finds them to be quite reagonable.

It is interesting to note that so little attention has been given in Brazil to improvements in market information, given the importance attached to exploitation by middlemen. This may have been a recognition of the basic inadequacy of the communication system. In any case, it wasn't until 19631964 that a reasonable sembiance of a market-information system was installed. This system tied together the market centers of Recife, Belo Horizonte, Säo Paulo, PBrto Alegre, and Rio de Janeiro. Prices of major agricultural products are now communicated among regions and published in each region on a daily basis.

In addition to the efforts to strengthen the marketing system, a second important policy instrument in the postwar period has been the subsidiza$t$ ion of the use of modern inputs. This policy was applied primarily to fertilizer and farm machinery. and couple of approaches have been used. In the $1950^{\prime} \mathrm{g}$, the policy measures took the form of exchange subsidies (preferential import exchange rates) and 
tax exemptions, while in the 1960's, subsidized credit has been the principal means of lowering their cost. The exchange subsidies were especially favorable to fertilizers.

The otrongly favorable exchange rate granted for fertilizer imports, together with tariff exemptions, state and federal tax exemptions, and highly preferential rail freight rates and port fees, undoubtedly stimulated the use of fertilizers. However, the fact that these policies did not have a major lmpact is clearly shown by the level of fertilizer consumption, which 1 s still extremely low.

Moreover, the policy most $11 k e l y$ had a deleterious effect in the long run. The tariff exemption and preferential exchange rate probable Inhibited the development of a viable domestic fertilizer induetry. Had the subsidy taken a different form, there might have been a greater investment in the local fertilizer industry, and the real price of fertilizer in Brazil today might well be much lower. It should be noted in passing that this was one of the deficiencies of the import-substitution industrialization program. since fertilizers had not been a major import, this industry did not benefit from the policies that were followed. Hence, an industry which could have contributed substantially to raising production in agriculture was largely neglected.

The policy followed since 1966 has been more rational in this regard. Direct subsidies were reintroduced with the creation of the Fund for Financial Incentives to the Uee of Fertilizers and Mineral Supplements. The program operates primarily through interegt rebates on bank loans for the purchase of fertilizers. In the presence of an infiation rate of 30 percent per year, this amounte to a negative real rate of interest of about 25 percent. Th1s acts to shift the demand curve for fertilizer to the right, and hould encourage investments in the fertilizer industry. In addition to this, the government is taking stepe to Increase the capacity of the fertilizer industry by more direct measures.

The third policy measure ueed in the postwar period was to increase agricultural credit for cult1vation expenses. This policy was given impetus by 
a food supply crisis in 1959, and was an important policy measure between 1960 and 1965 , although the extension of credit at negative rates of interest goes back as far as 1950 .

Between 1953 and 1964 the total value of loans to agriculture from official banks almost doubled in real terms. 7 Those to non-coffee growers increased even more. In addition, the percentage of agricultural units receiving Bank of Brazil loans increased from 1 percent in 1950 to 14 percent in 1964.8

It is also difficult to evaluate the impact of this program. It appears that there have been rather large distributional effects, with the larger farmers having more access to official credit sources than the small farmers. In addition, the credit supplied may have replaced that from other sources. To the extent that it replaced merchant-money lender credit, there was probably an increase in well-being from the policy. It is not clear that the increase in credit has led to substantial increases in output or in productivity.

A fourth policy instrument used in the period has been the use of minimum prices. 9 This price program was created in 1951, although it was largely ineffective until 1963. The prices set were almost always made ineffective by the rapid rate of inflation, with the result that market prices at the time of harvest were usually well above the price support. As a result, the only significant purchases prior to 1963 were of cotton during the 1952-1953 harvest.

The rise in farm prices in the period 19611963, and particularly the food supply crises of 1962, resulted in attempts to make the minimum-price policy more effective. Minimum prices were fixed before the planting season in an effort to influence production decisions. An effort was made to guarantee the price at the farm level, and not at some central marketing point, as had previously been done. And an attempt was made to adjust for inflation.

Even with these changes, however, the minimumprice policy has been effective only occasionally, and for individual products. Moreover, price supports appear to have been perverse in the recent period, in which they were closer to being effective. The support level appears to have been increased 
when prices were high, and decreased when they were 10w. If anything, then, they have tended to accentuate fluctuations in both production and prices, rather than to smooth out the cycles.

These farm policy instruments have been the major components of the explicit agricultural policy. Although a comprehensive evaluation of the policies goes beyond our present purposes, it appears that their effect in strengthening the agricultural sector has not been large and, moreover, that they have all had substantial distributional effects. Producers in the Central south have most likely benefited most from the policies, as have the larger producers in relation to the smaller. Both of these aspects accentuate distortions that already exist.

Agricultural policy has also involved a number of commodity programs. The most important of these has been for coffee. The major aspect of this policy was an attempt to exploit an inelastic demand curve by restricting marketings. The major portion of the gains from this policy were probably siphoned off into the industrial sector, and were an important source of development capital. Moreover, Brazil stuck to this policy long after its "monopoly" position had been eroded by the production stimulus given in other countries. Once production had been stimulated in other countries, the demand for Brazilian coffee was most likely no longer inelastic, and the marketing policy should have been quite different.

A similar policy was followed with cocoa, although the relative importance of the product was not as great, and its contribution to total development was much less. However, Brazil restricted its marketings in an attempt to support world prices for a longer period than did its competitors.

The sugar industry has been the recipient of a commodity program of a quite different kind. The predominant production zone was originally in the Northeast. However, its richer soils give the south an apparent comparative advantage. The shift to the South was creating serious income and employment problems in the Northeast, so the government undertook measures to protect the producers in that area. Although this was a means of cushioning the adjustment problem, no complementary policies were undertaken either to improve the competitive position of 
the Northeast producer or to create viable alternatives for him.

In addition to these policies that were designed to favor either the agricultural sector or groups of producers, there was another set of policies which had frankly harmful effects in the agricultural sector. One of these, and perhaps the more important, was the price-control policies of SUNAB. Although for the most part ineffective in attaining its avowed objectives, this organization has created considerable short-run instability in the market through periodic price rollbacks. The consequence is usually a disappearance from the market of the products affected, and the development of black markets. Although this usually forces a retreat from the original policy, both producers and consumers are affected in the short run, and ultimately in the long run.

The periodic discussion of land reform also appears to have had rather negative long-run effects. Although land reform has not been carried out on anything but a very minor scale, the public discussion at times reaches a rather intense level. This was especially the case in 1963 and early 1964. The uncertainty created by this public dialogue probably leads to an underinvestment in the agricultural sector, and a flight of capital to other sectors.

\section{PUBLIC ATTITUDE AND SUPPORT}

The public attitude toward agriculture in the past has tended to be one of neglect. The reasons for this are complex, but include: (1) basic cultural values, (2) ideological arguments that insist that to be agricultural is to be dependent on developed countries, (3) a rational desire to industrialize so as not to be dependent on world markets, and (4) a mistaken belief that industrialization in itself is the magic key to development.

The failure of Brazil to sustain its previous rapid rate of growth into the 1960 's is explained by many as due to the failure to develop its agricultural sector. This would appear to be an oversimplification of the problem. However, in part because of this diagnosis, a significant switch in both attitude and policy has taken place in recent years. 
Positive steps have been taken to strengthen the agricultural sector, although it could be argued that not enough is being done even yet.

Among the more important measures taken are the following: (1) A gradual reduction in the frequency of price rollbacks to benefit the consumer. (2) The elimination of controls on the export of agricultural products, thereby giving the farmer a larger market. This has been especially significant in the export of meat and meat products and of corn. (3) A reduction in the overvaluation of the cruzeiro, so that it currently is at about equilibrium, and the implementation of periodic devaluations. (4) The elimination of import subsidies on wheat, which not only helped the wheat producers, but also increased the demand for other cereals. (5) Increased programs of fomento, including the mass distribution of seeds, subsidization of fertilizer use, and an increase in agricultural credit. (6) The fixing of minimum prices before the planting season, so that they may serve as a guide to the producer, and the internalization of these prices to the rural areas, so that the producer--and not the middleman--receives the benefits. As a consequence of these measures, there has probably been a net transfer of income from the urban to the rural sector in the period since 1965 .

Although many of these policy measures are quite helpful in strengthening the agricultural sector, there remains a tendency to neglect the technological and educational problems of the industry. As has been shown, education in the rural areas is seriously deficient at all levels, and greatly behind that in the urban areas. Budgets for agricultural colleges and universities are still inadequate, and a tremendous amount of effort on the part of deans and rectors goes into obtaining and managing their resources. The importance of research is not generally recognized, and resources for this still tend to be minimal.

Hence, although the attitude and policy toward agriculture has grown more favorable, much room for improvement remains. This is especially important with respect to providing equal educational opportunities for rural people, and in providing adequate support for agricultural research. 
NOTES

1. Two valuable references on the Northeast are Albert 0 . Hirschman, Journeys Toward Progress: Studies of Economic Policy Making in Latin America (New York: Twentieth Century Fund, 1963), chapter 1; Stefan H. Robock, Brazil's Developing Northeast: A Study of Regional planning and Foreign Aid Washington, D.C.: Brookings Institution, 1963).

2. These data are taken from a compilation made by the office of the Foreign secretary, U.S. National Academy of Sciences, Washington, D.C. The material was originally presented in Part III of "Background Information," prepared for a workshop on the Contributions of Science and Technology to Development.

3. For a more detailed review and evaluation of agricultural policy in the postwar period, see Gordon W. Smith, "Brazilian Agricultural Policy: 1950-1967," in Howard S. Ellis, ed., Essays on the Economy of Brazil (Berkeley and Los Angeles: University of California Press, 1969).

4. See G. Edward Schuh, "Effect on Some Economic Development Policies on Agricultural Development," American Journal of Agricultural Economics, L, 5 (December, 1968), 1283-1293.

5. See Alan Abouchar, Diagnosis of the Transport Situation in Brazil (Rio de Janeiro: EPEA, 1967).

6. Gordon W. Smith, "Agricultural Marketing and Economic Development: A Brazilian Case Study" (unpublished Ph.D. thesis, Harvard University, 1965).

7. See Relatörio do Banco do Brasil 1965.

8. Crédito Agrfcola no Brasil (Rio de Janeiro: EPEA, $196 \overline{6})$.

9. For a brief history of the minimum-price policy in Brazil, and an evaluation of the social and treasury costs of alternative means of implementing it, see Euter Paniago, "An Evaluation of Agricultural Price Policies for selected Food Products: Brazil" (unpublished Ph.D. thesis, Purdue University, 1969). 
CHAPTER $\quad \begin{aligned} & \text { MARKETS AND THE } \\ & \text { SUPPLY INDUSTRIES }\end{aligned}$

This chapter is organized in three parts. The first part presents a qualitative description and analysis of the market institutions that service the agricultural sector. The second part discusses the transportation and communication systems, and the third part examines the nature of the several industries which supply inputs to agriculture, including irrigation.

\section{MARKET INSTITUTIONS SERVICING THE AGRICULTURAL SECTOR}

A considerable amount of resources has to be invested by an economy in order to carry out the marketing process, whether it be on the input side or on the product side. As soon as specialization in production takes place, exchanges of both resources and products must take place, and these exchanges require resources. 1 This is necessary regardless of whether the exchange is carried out through markets of free exchange or through a highly centralized, government-directed allocation.

In this section an assessment is made of the extent to which institutions have developed to handle this exchange function. Attention is focused on the market institutions per se, and not on the respective industries or the adequacy of market demand.

It should be remembered that a market system does more than transmit the product or resource that it is organized to handle. Marketcs are also important transmitters of information. 2 This important point should not be lost sight of when market systems are being developed. An important aspect of the 
efficiency of a market is the extent to which it does communicate information, and efforts should be made to see that this capacity is installed and maintained in the system.

Markets for Agricultural Inputs

The Labor Market 2

Little exists by way of a formalized system to facilitate the functioning of the agricultural labor market. This is the case both within the agricultural sector and between agriculture and the nonfarm sector. There are only limited governmental. institutions for providing job information, employment opportunities, skills needed, and such other information as would be required to facilitate the matching up of employment and people. Job information is generally passed from person. to person, with some information communicated through newspapers. In general, the cost of information search is relatively high.

In an economy that is changing as rapidly as the Brazilian economy, and with a labor force that tends to be rather mobile, such a service could make a very sizable contribution to a more efficient utilization of manpower. However, to be effective, the data collection in labor markets will have to be substantially expanded, and some effort will have to be made to analyze future job trends and to identify skills and skill needs among industries.

It is interesting to note that a rather specialized industry has arisen for hauling workers from one region to another. This has become most highly developed for transporting the workers from the Northeast to the South, although it also exists within and between other regions. Trucks are used in large numbers for this service, and until recently there was little or no safety inspection or regulation of this system. The system itself does, however, fill a real need, especially in view of the limited North-South public transportation systems, and undoubtedly serves as a means of communicating a great deal of information. 
A common argument among students of rural Brazil is that the agricultural labor force is exploited by large land holders.3 Although the evidence on this is not at all clear, 4 it should be recognized that such exploitation, if it exists, could be reduced in part by providing the labor market infrastructure that would at least eliminate the lack of information. Hence, government employment services to help match people and jobs, and labor market information services, could not only make for a more efficient allocation of resources, but could also reduce exploitation where it exists.

\section{The Credit and Capital Markets}

The credit and capital markets for agriculture have serious limitations. A reasonably strong banking system exists in Brazil. However, the system most likely works much more effectively in collecting and channeling savings out of agriculture than it does in reallocating them within the agricultural sector or from the non-farm to the farm sector.

The high rates of inflation place considerable stress on Brazilian capital markets. The risk is quite high, only a limited number of capital and credit instruments have been developed, and a highly integrated market has not developed except in some parts of the south.

Government intervention in credit markets has been great. Banks and loan agencies have been forced to limit their interest charges to 6-8 percent a year, in an environment in which the rate of inflation runs between 25 and 50 percent a year, and at times has been as high as 80 percent. Although this in principle represents a relatively large subsidy to the agricultural sector, the legislation has probably inhibited the development of credit programs for agriculture and prevented the credit from being allocated to its most socially productive uses.

As a result of the interest rate limitations, the allocation of funds has been largely independent of market forces. The demand schedule for credit in alternative uses is almost completely ignored, and the credit made available to agriculture at this rate tends to be allocated on the basis of personal friendship and influence. It is not at all clear 
that the use of these criteria results in channeling the limited resources into their highest use, or where they can contribute the most to increasing output.

A rather sizable informal credit market has developed in Brazil that is independent of the institutional structure. Little is known in a systematic way about this market, but it is very possible that at least as much credit is channeled into agriculture through this market as through the more formal, institutional market. Although information is extremely limited within the informal market, it most likely leads to a more rational use of resources than takes place through the formal, institutional sector.

\section{The Land Market}

A well-organized market for exchanging the property rights to land is not available in Brazil. Few firms specialize in providing this service. The problem is further complicated by an inadequate cadastral survey, recording systems that are complicated and inefficient, and a general lack of regulation and fiscalization. Given the rather large number of land transactions that take place in Brazil, a great deal could be gained from efforts and resources directed towards providing an infrastructure that would enable this market to perform more efficiently.

\section{Markets for New, Modern Inputs}

A marketing system or structure for handling the exchange of modern inputs has developed only in the southern part of Brazil. This is in large part because in other areas the modern inputs either are not available or are too high in price to be used. A system of agricultural production that depends in large part on a man, a hoe, and a plot of land, which is what characterizes large parts of Brazil, does not stimulate the development of a marketing system that will handle fertilizer, machinery and equipment, tractors, and fungicides and insecticides.

As the supply industries for these new inputs develop, considerable resources will be involved in providing the market system to distribute them to the farmers. This will be the case regardless of whether the distribution is made through free markets or by the government. 
In the more developed parts of Brazil, where these inputs are now in use, a market system for their distribution has developed. These markets are at best imperfect, however. Even when a farmer wants to use these inputs, he has difficulty in getting them where he wants them, when he wants them, and of the kind he wants. In many cases he will have to spend considerable time and effort to obtain such inputs.

\section{Product Markets}

The marketing system for agricultural products tends to be much more developed than that for agricultural inputs. Although its deficiencies are probably not as great as commonly believed, there are still rather important defects in the degree to which it handles its allocatory function. The food sector is frequently subjected to gluts and shortages, both geographicaliy and over time. Produce may rot in one location, at the same time that it is not available in another. Large harvests either have to be sold immediately on the market at whatever price they will bring, or placed on the international market, to be, in effect, bought back the following year when production declines.

This section is organized in three parts. The first part treats the domestic marketing system. The second part examines the system for international trade. And the third part considers the rapidly growing food processing industry.

The Domestic Marketing system

The most serious deficiencies of the marketing system arise from the lack of market information and the inadequacy of the transportation system. A market information system is beginning to be developed, largely at the instigation of the Ministry of Agriculture and the state Secretariats of Agriculture of Minas Gerais and São Paulo (with support from USAIDPASA). * The system integrates the major market centers of Recife, Belo Horizonte, são paulo, porto Alegre, and Rio de Janeiro. However, a system for

*PASA stands for Participating Agency Service Agreement. 
distributing the information so obtained and making it widely available is just now beginning to be developed.

Free markets cannot handle their exchange function efficiently unless information is freely available. In the present situation, decisions tend to be made in a vacuum, and the market has difficulty in responding to changing economic conditions. The provision of this market information is a legitimate governmental function; and until it is provided, considerable economic waste will continue to be incurred.

The inadequacy of the transportation system is a second major factor contributing to deficiencies in the marketing system. The mileage of paved roads is still relatively small for a country the size of Brazil, the railroad system is terribly inadequate, and water transportation is not well developed, despite the extensive coastline. A major problem is the inefficiency of the ports.

One very strong component of the marketing system is the large private fleet of trucks, many of them individually owned, that ply the roads of Brazil, buying produce and hauling it from one place to another. The owners of these trucks, entrepreneurs in themselves, must indeed be making a great contribution to more effective markets, al though their contribution tends to be little recognized by contemporary society.

The lack of adequate storage facilities is frequently given as a major cause of deficiencies in the marketing system. Although this may have been valid at an earlier date, it does not seem to be of major importance at the present time. The construction programs of the $1950^{\prime} \mathrm{s}$ appear to have resulted in a reasonably adequate system, especially in the areas of highly commercialized agriculture. On-thefarm storage is not great, but this is probably as much a result of the lack of suitable credit instruments as of anything else.

The lack of an effective system of standards and grades is a defect of the marketing sytem. This makes the exchange function a risky venture, inhibits the handing of transactions at a distance, and makes the collection and dissemination of market information at best difficult. 
With one or two important exceptions, cooperatives have not played a major role in the marketing of products or inputs. Until recently they received no fiscal advantage, and the entrepreneurial talent appeared to be lacking. The major exception to this has been the Japanese cooperative, COTIA, in São Paulo, which is a large, powerful cooperative for th the marketing of both agricultural products and agricultural inputs. This cooperative also provides strong technical assistance services to its members and publishes an excellent farm magazine.

To conclude this section, it should be pointed out that the degree of development of the marketing system varies a great deal from one part of Brazil to another. In São Paulo, for example, a wholesalerretailer system is well developed, with adequate marketing facilities, terminal markets, and a retail system that works quite well. In other parts of Brazil, the marketing system is quite deficient, and the integration of producers and consumers through the exchange system is at best tenuous.

\section{The Marketing System for Foreign Trade}

Some of the deficiencies of the internal market are also important in the foreign trade market. Bottlenecks in the transportation system, especially in the ports, lead to costly delays and high marketing charges. The system of market information is inadequate; and the lack of standards and grades, especially for non-traditional exports, increases the risks associated with Brazilian products.

The negative approach which Brazil has taken towards exports in the postwar period has had a serious effect on the development of an adequate infrastructure. Discrimination against this sector has been especially severe, and has not only discouraged private investment, but has also inhibited the development of entrepreneurial talent to exploit foreign trade opportunities.

\section{Food Processing Industry}

The bulk of agricultural production is marketed with very little processing or packaging. The "free fair" is still an important point of retailer-toconsumer exchanges, and much of what passes through these markets is unprocessed and unpackaged. Even 
in the larger cities these markets remain an important retail outlet.

However, the processing and packaging industries are beginning to develop; and in the larger cities, modern supermarkets are increasing in number. The meat-packing industry is growing rapidly, as is the system for processing milk and distributing it. Both sectors, however, remain at a relatively low level of development. The processing and packaging of fruits and vegetables is even more limited, although it also is growing.

\section{THE TRANSPORTATION AND COMMUNICATION SYSTEM}

The transportation of agricultural products to market is a serious problem in Brazil, but has received relatively little attention until recently. Transportation services are a critical input in the effective distribution and use of agricultural resources and in the welfare of rural people. The fact that agricultural production is concentrated in the southern states, while large concentrations of people live in the Northeast, gives added importance to this problem.

Some of the pertinent data are summarized in Table 109 and 110. An extensive program of road construction has been carried out since 1960, and there has been a rapid increase in the kilometers of paved roads. The large increase in road construction between 1960 and 1965 was in county roads, an important aspect of the local farm-to-market complex.

Data on the volume of shipping by the alternative systems is shown in Table 110. Between 1960 and 1965 the volume transported by railroads increased approximately a third, while coastal shipping virtually stagnated. The ton-kilometers transported by highways, however, increased by 68 percent. By 1965 some 68 percent of the commodities were transported by highways.

Transportation facilities differ among the various parts of the country. The Northeast depends mainly on roads and coastal shipping. The East has 
TABLE 109

Development of Federal, state, and

County Road Network

\begin{tabular}{|c|c|c|c|c|c|c|}
\hline \multirow[b]{2}{*}{ Year } & \multicolumn{3}{|c|}{ Federal } & \multicolumn{2}{|c|}{ state } & \multirow[b]{2}{*}{ County } \\
\hline & Total & Total & Paved & Total & Paved & \\
\hline & \multicolumn{6}{|c|}{ (kilometers) } \\
\hline 1952 & 302,147 & 12,315 & $\mathrm{n} \cdot \mathrm{a}$ & 51,032 & n.a. & 238,800 \\
\hline 1956 & 465,868 & 22,859 & 2,900 & 59,593 & 1,234 & 383,416 \\
\hline 1960 & 468,048 & 32,402 & 8,675 & 75,875 & 4,028 & 359,771 \\
\hline 1965 & 803,068 & 36,170 & 13,039 & 99,568 & 13,507 & 667,330 \\
\hline
\end{tabular}

Source: Alan Abouchar, Diagnosis of the Transport Situation in Brazil (Rio de Janeiro: EPEA, 1967), p. 47 
TABLE 110

Commodities Transported by Rail, Highway, and Coastal shipping

(million ton-km.)

\begin{tabular}{|c|c|c|c|c|c|c|}
\hline Year & Railroads & Index & Highways & Index & $\begin{array}{l}\text { Coastal } \\
\text { Shipping }\end{array}$ & Index \\
\hline 1950 & 8,828 & 100 & 10,817 & 100 & 9,237 & 100 \\
\hline 1955 & 9,337 & 106 & 23,100 & 214 & 11,320 & 123 \\
\hline 1960 & 12,078 & 137 & 42,556 & 393 & 14,546 & 158 \\
\hline 1963 & 15,342 & 174 & 62,056 & 574 & 15,445 & 167 \\
\hline 1965 & 18,800 & 213 & 71,600 & 662 & 14,000 & 152 \\
\hline
\end{tabular}

Source: Alan Abouchar, Diagnosis of the Transport Situation in Brazil (Rio de Janeiro: EPEA, 1967), p. 4 . 
good, though insufficient, facilities for road, railroad, and river transport. The Central West depends on road and river transport, since only a few rail lines penetrate deeply into the region. In the South, the road and railroad systems are relatively good.

In all regions other than the South the transportation of agricultural produce is irregular and costly. Harbor installations are inadequate and out of date, roads are bad, shipments are delayed, and losses from deterioration are high.

The serious nature of the transportation problem in Brazil has been highlighted in a number of studies. Some of the important aspects of the situation are as follows:

1. Of the nation's 500,000-mile road system in 1962 , only about 3 percent were paved inter-city roads. Consequently truck transport costs are high, and many communities are difficult, and at times impossible, to service.

Total road mileage has expanded since that time, as has the amount of paved highways. The current government is investing heavily in the transportation system, but the magnitude of the task is indeed great.

2. Brazil's pattern of settlement has affected the pattern of its road system. The distribution of the population along the long seacoast, with relatively slow penetration to the interior, has resulted in a road system that tends to connect the interior to the coastal cities, but does not integrate the cities within the interior.

3. The present railroad system is ill-suited to the needs of modern Brazil. One complication is the fact that three separate gauges are in use, thus making effective interchange of freight costly and difficult. Railroads also were originally built to tap the interior regions and move products to port for export. Thus, no coordinated intra-national transportation system has been developed. In addition, neither the system nor the equipment has been modernized.

The public subsidy to railroads has been high, especially to that part which is nationalized. The 
need for the subsidy has come about because of the inefficiency in operation and the tendency to hold transportation rates down in the guise of controlling inflation. This has been self-defeating, since it is necessary to print money to pay the deficit, and this is the source of added inflation.

4. Water transportation is relatively slow, and the ports are terribly inefficient. Labor costs are quite high, and at times ships have had to wait as much as a month to be unloaded. Moreover, many ships in the Brazilian maritime fleet are old and poorly maintained. It was reported in 1966 that as high as 25 percent of all cargo ships were out of commission at any given time, and that 20 percent of the remainder were in the process of repair.

Two examples will indicate the inefficiencies in the port and water transportation systems. It has been estimated that the cost of taking cocoa beans from the dock at Ilheus in Bahia and loading it on the ship is greater than the combined cost of hauling it to New York and unloading it. Within Brazil, it has been estimated that it is cheaper to haul fertilizer from the Northeast to the South by truck than to place it on ships and take it along the coast by water. This is a serious distortion of what ought to be the relative real costs of transporting a heavy, bulky commodity such as fertilizer.

Brazil has recognized the problems in its transportation system, and is concentrating on improving it. Current plans include:

1. A 50 percent increase in railroad mileage. About one-fourth of this is now under construction, and emphasis is on coordinating the present rail system and developing additional lines to help open up frontier areas.

2. A port plan calling for further development of all ports, supported by necessary improvements in ships and storage facilities.

3. A road system plan calling for the development of numerous transcontinental roads and construction and surfacing of a large number of connecting and feeder highways. 
Unfortunately, not enough attention appears to be given to improving the operating efficiency of either the railroads or the ports.

The greatest progress is taking place in the road system. The construction of Brasflia, although done at a very high cost, has provided a focal point in the interior for integrating the country. Modern, paved highways now connect São Paulo, Rio de Janeiro, Belo Horizonte, and Brasilia. This has given a strong stimulus to this part of the country, both in the agricultural sector and in the industrial sector.

In addition, a paved highway (the Rio-Bahia) was completed in 1964 that connected the Northeast to the South. An unpaved road has been constructed from Brasilia north to Belem. Both of these roads are stimulating considerable development along their extension, and contributing substantially to the integration of the respective regional economies.

A road is under construction that will connect Belo Horizonte with the east coast and, on the west, to the agriculturally rich Triangulo Mineiro. In the Northeast, roads are under construction connecting Recife to Fortaleza and, in turn, to Belem. Both of these can make a substantial contribution to their respective regions.

Finally, although air transportation is not important for hauling agricultural produce, it is important to recognize that Brazil has a reasonably good air system. The commercial flights provide an important function in connecting the major cities; and, in addition, Brazil has a well-developed system of air taxis. Although both were heavily subsidized in the past, this subsidy has been reduced in recent years.

The system of communications is as deficient as the transportation system. Inter-city telephone calls are at best difficult, and the number of telephones in relation to the total population is small. Telegrams can take days to reach their destination, although the telegraph system is relatively extensive. Mail can take as much as one to two weeks just to go from one part of Brazil to another.

Improvement in this sector is imperative. The cost to the economy of such an inadequate communication system is indeed great. It is a major factor 
inhibiting the development of an efficient marketing system.

\section{SUPPLY INDUSTRIES}

By supply industries, we mean the industries that produce inputs for use in the agricultural sector. We include in this discussion the quantitative aspects of the agricultural credit market, even though it is not properly an industry in the sense of the others to be considered. It does provide a potentially important input, and for that reason we include it here. Similar comments apply to irrigation, which is also discussed in this section.

Industries that supply modern inputs for the agricultural sector are not well developed. There appear to be at least two reasons for this. One is the rather low level of technology. used in most of the agricultural sector. Without knowledge on the part of the farmer, he cannot demand the inputs; and without the demand, the industry does not develop.

Equally, if not more, important, however, has been the character of the development process pursued as a national policy. Brazil's industrialization has been oriented toward import-substitution. As a consequence, it has ignored production for mass markets and production of inputs that might be used in modernizing the agricultural sector.

The discussion which followg considers the major inputs needed for the modernization of agriculture.

Machinery, Equipment, and Tractors

An important component of Brazil'a industrialization has been the development of a strong automobile indugtry. A liberal dose of foreign capital has led to the development of a number of strong companies, and the country probably has the strongest automotive industry in Latin America.5

An important component of this industry is the manufacture of trucks. This sector has developed so well that Brazil is practically self-sufficient, 
and in the near future could produce substantial amounts for export. 6

However, a strong machinery and equipment and tractor industry has not been developed. Up unt11 1960, all of the tractors in the country were $1 \mathrm{~m}$ ported. In 1961 , the national industry started to produce, and in 1965 the total production had attained a level of only 8,121 units. Of these, 2,066 were of the heavy type, 5,814 were medium-size, and 241 were small or light tractors.

A almilar story applies to machinery and equipment. Some of the mall tools are produced in Brazil, but the major fraction of the machinery and equipment is imported. Much of this is done through direct purchases by large farmers or alrectly by the government, which either puts them in tractor patrols for fomento work or selis them at cost.

\section{Fert $111 z e r \theta$}

The domestic fertilizer industry is also quite IImited, despite the fact that Brazil appears to have an adequate raw matertal endowment for the manufacture of most fertilizers. The following presents a nutrient-by-nutrient evaluation.7

\section{Nitrogen}

Only a little more than one-fifth of the total supply in 1963 was produced in Braz1l. In 1964 it was only 10 percent. of this, the principal product was calcium nitrate, which $1 \mathrm{~g}$ produced only by Petrobras, the national petroleum company. The $1 \mathrm{~m}$ port cost in 1963 was $\$ 11.9$ million, with the major fraction being imported from Europe. West Germany supplied 48 percent of the total in 1962 , with Chile supplying 15 percent, the United States 5.6 percent, and Ruseia 3 percent.

It 18 estimated that Brazil currently 18 using 40 percent of 1 to nitrogen fertilizer for alrect application, all in soltd forms-princlpally ammontum sulphate. The liquid forms, such as anhydrous ammonta, are not used because they are not available and because of an erroneous bellef that the technology necessary for their use 18 too advanced for the current condition of Brazilian agriculture. 
Brazil could rather easily become self-sufficient in the production of nitrogen fertilizer. In fact, if all existing plans for its production were realized, production would be three times the estimated minimal needs for 1970. Each of the various alternatives for becoming self-sufficient involves the utilization of the by-products of the steel and petroleum industries and of natural gas available in Bahia.

\section{Phosphorus}

Brazil has been increasing its production of phosphate fertilizers, but in 1963 was still producing only about 30 percent of the total used. Brazil could become self-sufficient by the early 1970's, since there are large and adequate deposits of phosphate in the North, Central and South regions which guarantee a sufficient supply for the areas currently cultivated and that will be cultivated in the near future.

In the Northeast, the principal deposit is that controlled by Fosforita de olinda, near Recife. Latest information indicates a reserve of 30-50 million metric tons. Of this total, only 3-4 million tons can be taken by the currently used method of open excavation, with the existing equipment, because of the large quantities of impurities. It is estimated that the equipment necessary for subterranean excavation would cost $\$ 1-1.5$ million, and the major part would have to be imported.

Although there is currently a well-established and maintained factory in operation, with a capacity of at least 200,000 tons per year, the high cost of transportation and the limitations of the market provoked a drop in production, from 165,000 tons in 1959 to 50,000 tons in 1963. This resulted in financial difficulties for the owners, since the minimal level of economic production is between 80,000 and 100,000 tons per year. In the past, the high cost of freight was due more to high port rates and the mandatory use of Brazilian ships than to limitations of equipment or technique. In addition, the imported product was benefited by a low exchange rate, while that of olinda had to be moved at the free exchange rate. This situation has been corrected. 
Another problem is that the production of this factory is divided equally between two standards. The product with 33 to 34 percent $\mathrm{P}_{2} \mathrm{O}_{5}$ is reasonably good for acidification and is sold dry, not ground, for the manufacture of simple phosphate. The other is a fine portion, of which 24 percent has a high silica content and 23 percent has a high content of iron and aluminum. This produat is not adequate for acidulation into simple phosphate, and it would be relatively expensive and difficult for the manufacture of $\mathrm{H}_{3} \mathrm{PO}_{4}$. The current practice is to $\mathrm{mix}$ the two materials and sell a product of 28 to 30 percent $\mathrm{P}_{2} \mathrm{O}_{5}$, ground and sacked, for direct application to the soil. There apparently does not exist a practical method for the concentration of the inferior product.

About half of the production in 1963 was used in the surrounding region and in the production of sugarcane. The remainder was exported to the South or used for acidulation. Installations and supplies are more than adequate for the near future.

The largest known deposit of phosphate in Brazil is in the Central region. With a viable plan for the production of thermophosphate from a product that is of low quality, it appears that the central region can shortly become self-sufficient in $\mathrm{P}_{2} \mathrm{O}_{5}$, both for direct application and for soluble forms. The deposit in Araxa, Minas Gerais, which is controlled by CAMIG, is said to contain 90 million tons of phosphate mineral, with a high content of iron and not appropriate for acidulation. The concentrate of this operation, which contains 28 to 30 percent of $\mathrm{P}_{2} \mathrm{O}_{5}$, is currently ground and utilized for direct application to the soil. The current rate of use is about 30,000 tons per year.

A well-developed plan for obtaining a material that results from the fusion of magnesium silicate and tricalcium phosphate was under study for approval by AID. The plan foresaw the production of 50,000 tons of thermophosphate with 20 percent $\mathrm{P}_{2} \mathrm{O}_{5}$ per year in each one of three entities, to be constructed in successive years, according to the development of the market. The total capacity' would be 150,000 tons per year. In addition to this, CAMIG plans to continue the production of the material for direct application and will increase production to 40,000 tons per year. 
At the rate of 40,000 and 150,000 tons per year, the deposit at Araxa would last 300 years. Hence, the supply is adequate. Although thermophosphate has practically no $\mathrm{P}_{2} \mathrm{O}_{5}$ soluble in water, it is highly available and could constitute an excellent source of $\mathrm{P}_{2} \mathrm{O}_{5}$ in the acid soils that are so abundant in Brazil.

The principal deposit in the South is in Jacapiranga. Plans have been developed for a factory in this area. It is proposed to use a new method of processing which will utilize deposits of low quality.

In the near future, however, even though Brazil should become self-sufficient in the production of phosphorus fertilizer, the bulk of that used in the South will have to come from the Central and Northeast regions. It should be remembered that almost 90 percent of the consumption of fertilizer and 55 percent of the value of agricultural production is in the four southern states of são Paulo, Paraná, Santa Catarina, and Rio Grande do.Sul. Hence, transportation facilities for handling this intra-country transfer will have to be developed.

Potassium

No deposits of potassium minerals are known to exist in Brazil. For the immediate future, dependence on the external market will be necessary.

Iime

Brazil now is producing practically all of the lime that it is consuming. The estimated production of 250,000 metric tons in 1963 was far below the needs, however, given the high acidity of Brazilian soils.

Deposits of lime, both dolomitic and calcitic, are well distributed through the East and Central regions of the country, as well as in the southern part of Goils and Mato Grosso. Brazil could become self-sufficient in the production of lime.

Essential Minerals

The essential minerals are salt, phosphorus, and calcium, together with other minor elements. of these, salt is almost universally deficient, although serious deficiencies in the others also exist. 
Although present capacity for these minerals is limited, there should be no difficulty in supplying them domestically if the respective industries are developed. Salt comes from the evaporation of the sea--and this can easily be increased. In addition, there are large rock salt deposits in the Amazon Basin. Calcium and phosphorus can be obtained in sufficient quantities from bone meal and defluorinated tricalcium phosphate, which is produced from simple superphosphate.

\section{Summary}

In the past, Brazil has depended heavily on imports as a source of fertilizers. With the exception of potash, a limited industrial structure exists for the production of all of these materials. However, a raw material base is available that would enable Brazil to become self-sufficient in all except potash.

The lack of an adequate and efficient system of transport has been one of the principal limiting factors for the fertilizer industry. The rates for sea transport, plus the port fees for minerals, have been so high that in 1964 it was cheaper to transport phosphate minerals from the United States or Africa to Santos, são Paulo, than from Recife in the Northeast to santos. The congestion in the ports and the high charges for handling the cargo, especially in santos, make this problem even more serious. Moreover, the lack of an adequate railroad system restricts the transport of fertilizers among the various regions and makes the development of regional sources of supply very important.

\section{Agricultural credit}

There are a number of sources of agricultural credit in Brazil. The oldest and perhaps most widespread is the middleman. At the beginning of the season the farmer receives a credit to cover his purchases, the hire of extra labor, and living expenses. He guarantees to repay this loan with his crop at the end of the crop year. The actual amount of credit extended to agriculture in this form is unknown, but it is a common practice. 
The principal source of credit from the government to agriculture is through the Carteira de credito Agricola e Industrial (CREAI) of the Banco do Brasil. The fraction of total funds extended by the Banco do Brasil which has gone for agriculture has been extremely small, especially in light of the relative importance of agriculture in the economy.

Although previous attempts had been made, official credit assistance began in 1937 with CREAI. The number of loan contracts increased slowly until the $1950^{\prime} \mathrm{s}$. Only after 1958 was the increase rapid, and by 1961 a significant increase had been obtained.

Even so, credits extended by the bank to agriculture in 1961 were reported to number only 225,000 --as compared with a total of about 2 million farmers. The amount loaned was NCr $\$ 68,384$ thousand, exclusive of that which went to rural industries and cooperatives. This was approximately U.S.\$230 million, or slightly over $\$ 1,000$ per loan.

Most of the loans were for crop production, with about 40 percent of the total going for the production of rice, coffee, cotton, and corn. of these four, rice received the greatest amount of credit in 1961. Coffee used to receive the greatest amount, but has more recently dropped to second place. (In 1957 these four crops were granted 70 percent of the total credit for agricultural credit. In that same year, coffee received 50 percent of the total credits for these four crops.)

More recent data on the credit extended by the CREAI are given in Table 111. (It is reported that a large part of the credit extended to farmers by middlemen comes originally from the Banco do Brasil; and is represented by loans and discounts of CREGE (Carteira de Credito Geral). The loans of CREGE might have been added to those of CREAI for a more complete picture of agricultural credit, although it is not known what fraction of the CREGE agricultural credit is for merchant stocks and what fraction is for direct agricultural purposes.) The data show the relatively small fraction of credit going for livestock production, and the relatively large fraction going for current crop production. They also show the sizable increase in credit activity in 1964, and then the return to a lower level in 1965, when restrictive monetary policies were being followed. The 
total of U.S.\$287 million extended in 1965 is some 25 percent greater than it was in 1961, thus reflecting the conscious policy of extending more credit to agriculture.

Most agricultural loans are for one crop season and must be repaid within a year. Such loans are to be used for the period between sowing and harvest, and for transportation and storage. A two-year loan may be granted to purchase fertilizers, seeds, insecticides, fungicides, and tools. Four-year loans may be granted for agricultural machinery, motor and animal traction, and construction. Medium- and longterm projects may sometimes be financed with loans for up to eight years. One-year loans are granted for fattening cattle, and three-year loans for cattle breeding.

On all loans a borrower pays 7 percent interest plus a 1 percent service charge. Given the rate of inflation, this of course represents a sizable subsidy. In practice, the supply of loan funds is limited because lenders do not wish to risk the effects of inflation.

Despite the efforts of CREAI to increase the number of loans to small farmers, it is estimated that about 90 percent of the credit available is supplied to larger land holders.

other sources of credit for agriculture are provided by the state banks and by several public or mixed enterprises. The state of são Paulo has the best network of credit agencies. Both the Banco do Brasil and the Banco do Estado de são Paulo have some 200 agencies distributed throughout the state. The state bank allows the regional agronomists to make arrangements for credit applications where no agency exists.

The major public or mixed enterprises extending credit to agriculture are:

National Bank of Cooperative Credit

Bank of the Northeast of Brazil

Amazon Bank of Credit

Caixas Economicos

Commission of Production Finance 
TABLE 111

Loans Granted by CREAI, 1963-1965

\begin{tabular}{|c|c|c|c|c|c|c|}
\hline & $1963^{\text {Num }}$ & $\begin{array}{l}\text { ber of Lo } \\
1964\end{array}$ & $\begin{array}{l}\text { ans } \\
1965\end{array}$ & $\begin{array}{l}\text { Value } \\
1963\end{array}$ & $\begin{array}{l}\text { (thousand } \\
1964\end{array}$ & $\begin{array}{l}\text { NCr\$) } \\
1965\end{array}$ \\
\hline \multicolumn{7}{|l|}{ Crops } \\
\hline $\begin{array}{l}\text { General Crop Expense } \\
\text { Cotton } \\
\text { Rice } \\
\text { Coffee } \\
\text { Sugarcane } \\
\text { Beans } \\
\text { Tobacco } \\
\text { Mandioca. } \\
\text { Corn } \\
\text { Wheat } \\
\text { Other }\end{array}$ & $\begin{array}{r}284,964 \\
55,922 \\
66,039 \\
9,677 \\
3,400 \\
18,014 \\
10,201 \\
34,044 \\
58,119 \\
7,666 \\
21,882\end{array}$ & $\begin{array}{r}360,543 \\
74,046 \\
81,917 \\
19,998 \\
7,083 \\
24,520 \\
12,521 \\
27,840 \\
71,798 \\
6,922 \\
33,898\end{array}$ & $\begin{array}{r}297,963 \\
66,609 \\
47,412 \\
17,772 \\
4,571 \\
14,265 \\
7,897 \\
18,243 \\
77,321 \\
6,652 \\
37,221\end{array}$ & $\begin{array}{r}119,179 \\
17,098 \\
43,299 \\
9,590 \\
3,582 \\
4,873 \\
1,274 \\
4,722 \\
19,579 \\
4,944 \\
10,218\end{array}$ & $\begin{array}{r}307,577 \\
42,161 \\
109,776 \\
40,301 \\
17,645 \\
9,097 \\
2,813 \\
6,213 \\
46,087 \\
7,998 \\
25,486\end{array}$ & $\begin{array}{r}367,920 \\
74,075 \\
82,766 \\
37,490 \\
23,820 \\
13,102 \\
3,018 \\
6,384 \\
66,617 \\
17,335 \\
43,313\end{array}$ \\
\hline $\begin{array}{l}\text { General Crop Expense, } \\
\text { Extractive Crops }\end{array}$ & 1,009 & 1,641 & 1,381 & 595 & 1,667 & 2,497 \\
\hline $\begin{array}{l}\text { Storage and Marketing } \\
\text { (Cotton rice, corn, etc.) }\end{array}$ & 2,868 & 9,438 & 497 & 2,916 & 14,613 & 1,663 \\
\hline Formation of Permanent Crops & 3,410 & 6,836 & 3,906 & 1,623 & 3,978 & 4,339 \\
\hline $\begin{array}{l}\text { Improvements of Crop } \\
\text { Explorations }\end{array}$ & 16,214 & 27,299 & 23,369 & 8,703 & 20,865 & 25,314 \\
\hline
\end{tabular}




\begin{tabular}{|c|c|c|c|c|c|c|}
\hline & \multicolumn{3}{|c|}{ Number of Loans } & $\begin{array}{l}\text { Value } \\
1963\end{array}$ & $\begin{array}{l}\text { (thous and } \\
1964\end{array}$ & $\begin{array}{l}\text { NCr\$) } \\
1965\end{array}$ \\
\hline $\begin{array}{l}\text { Machinery and Equipment } \\
\text { Purchase }\end{array}$ & 9,453 & 11,250 & 9,888 & 21,343 & 48,553 & 56,483 \\
\hline $\begin{array}{l}\text { Vehicle and Work Animal } \\
\text { Purchage }\end{array}$ & 14,410 & 20,876 & 16,025 & 7,567 & 13,736 & 12,018 \\
\hline Other & 32,939 & 23,750 & 12,330 & 6,343 & 7,282 & 4,955 \\
\hline Total & 365,267 & 461,633 & 365,359 & 168,269 & 418,271 & 475,189 \\
\hline Total (U.S.\$) & & & & & $\$ 345 \mathrm{mil}$. & $\$ 253 \mathrm{mil}$. \\
\hline \multicolumn{7}{|l|}{ Lives tock } \\
\hline Acquisition of Animals & 13,553 & 23,993 & 13,796 & 12,480 & 29,332 & 15,597 \\
\hline Rasture Expenses & 6,185 & 8,303 & 7,505 & 2,777 & 7,007 & 8,662 \\
\hline Pasture Improvements & 9,282 & 14,011 & 16,686 & 7,047 & 15,971 & 25,795 \\
\hline $\begin{array}{l}\text { Machinery, Equipment } \\
\text { Purchase }\end{array}$ & 1,422 & 2,862 & 3,635 & 1,774 & 5,176 & 10,257 \\
\hline Vehicle, Animal Purchase & 1,908 & 3,218 & 2,308 & 1,711 & 3,853 & 3,823 \\
\hline other & 744 & 2,265 & 1,130 & 140 & 672 & 556 \\
\hline Total & 33,094 & 54,652 & 45,060 & 25,929 & 62,011 & 64,690 \\
\hline Total (U.S.\$) & & & & & $\$ 51 \mathrm{mil}$. & $\$ 34 \mathrm{mil}$. \\
\hline
\end{tabular}

Source: Anuario Estatistico do Brasil 1965 (Rio de Janeiro: IBGE, 1966). 
Autonomous institutions such as the Commission of the São Francisco Valley and IBC also extend credit, as do some private banks and credit cooperatives. Data are not available on the amount of credit extended by these agencies to the rural sector, however.

Cooperatives are able to obtain short-term loans for agriculture and livestock, 10-year loans for construction and stationary machinery, and 15year loans for the purchase of land. Credit to cooperatives is gradually increasing in importance. Both CREAI and the National Bank of Cooperative Credit extend such credit. As an example of the magnitude of these programs, the National Bank in 1965 extended NCr\$47.560 million (U.5.\$25.3 million) to cooperatives. Most of this went to agricultural cooperatives.

A number of banks provide supervised rural credit at the request of the regional extension services. This type of credit began with the establishment of ACAR in Minas Gerais, in 1948. Supervised loans are granted on a short-term basis, from one to three years, to carefully selected farmers who receive advice on how to apply their credit properly. These loans are also extended at 8 percent per year, and the total amount is not great.

Conclusion

Comprehensive data on the amount of credit extended to agriculture are sorely lacking. Numerous governmental agencies and official establishments extend credit to farmers. However, the fraction of their loans going to agriculture is generally small. It should be remembered, however, that the total amount of credit granted to producers by merchants, machinery sales organizations, and private individuals is most likely substantially greater than that extended through "official" organizations.

Three major factors limit the supply of funds available. The first is the obvious one of inflation. Without monetary correction, loans in an inflationary situation are bad business. This is compounded by the legislation, which fixes the rate of interest at such low levels when the inflation is so high. The interest rates could compensate for the inflation if they were permitted to do so. The 
final factor inhibiting the extension of credit to agriculture is the instability in this sector. Both relative prices and yields fluctuate a great deal from year to year. Credit instruments have not been developed to handle this uncertainty.

One of the more serious problems with the credit that is extended is the lack of longer-term loans. This too is a reflection of the above factors. But the provision of long-term loans would facilitate land transfers and encourage a more rational exploration of soil resources, in place of the present "mining" which takes place in order to pay a farm off in two to three years. More intermediate-term credit would facilitate the acquisition of farm machinery, the upgrading of livestock herds, and the purchase of other inputs required for modernizing agricultural production.

An additional problem is the extension of credit by official organizations primarily to large producers. This is probably a rational response to the costs of servicing the loans, especially in view of the interest ceilings. On the other hand, the small producers are usually the ones most subject to internal credit rationing.

A final problem in the credit system is the lack of persons trained in the application of credit. This applies both to rural people and to bank employees. Little or no attempt has been made by banks to employ agrónomos. Moreover, agrónomos working in extension or other organizations have little specialized knowledge about credit and its use. This in part reflects their general lack of economic training.

On the positive side, many measures have been taken in recent years to promote an increase in the flow of credit to agriculture. The bulk of the short-term bank credit for agriculture is still supplied by the Bank of Brazil; but commercial banks have been encouraged, since November 1963, to be more active in this field. This has been done in part by allowing the inclusion of certain types of agricultural loans in required reserves. The scope of this provision was further expanded in July 1964.

In addition, the National Agency for the Coordination of Rural credit was created to permit the 
development of a coherent agricultural credit policy and the channeling of external financing to agriculture. A special fund (National Fund for Rural Refinancing) receives foreign aid counterpart funds to supplement domestic resources. In this framework, steps have been taken to increase not only the availability of short-term credit to agriculture, but also to offer medium-term credit to finance the purchase of fertilizers and to facilitate the acquisition of agricultural machinery and tractors.

\section{Chemical-Based Industries}

Agricultural inputs that are based on chemical products, such as insecticides, fungicides, and other pesticides are being used in increasing quantities. This is especially the case in the southern part of Brazil, and particularly são Paulo. Most of these products, however, are imported.

Many of these imports could be produced domestically, since Brazil is developing a modern chemical industry. This should provide a basis for producing these chemical products when sufficient demand for them from the rural sector arises. Alternatively, development of these industries would most likely result in a reduction in the price of these imports and stimulate an increase in their use.

\section{Seeds}

A specialized seed industry does not exist-with a couple of important exceptions. In general the farmer uses seed saved from the previous year's production, or obtains it from a neighboring farmer. In large areas of Brazil, little or no attention is given to using selected or high-quality seeds.

An important exception is hybrid seed corn. number of strong companies are producing and distributing hybrid seed. One of their problems, however, is the lack of a supporting base--the universities or research institutions to generate new inbred lines and new crosses.

Another important exception is the production of cotton seed in São Paulo. This is carried out by the state Secretariat of Agriculture with some 
contracting-out to farmers; and a strong effort is made to distribute high-quality seeds of the highyield varieties developed in that state. (The Secretariat also distributes other improved seeds.)

A few other companies are involved in distributing high-quality seeds. In general, however, this industry is not now adequate to provide the seeds for a modern agriculture.

\section{Power and Fuel}

An important factor inhibiting the total development of Brazil has been the lack of organic fuels. Coal deposits are small and of relatively low quality. Moreover, they are not located near the large iron ore deposits that Brazil has.

Oil supplies have been extremely limited, with most of the wells located in Bahia. The bulk of Brazil's petroleum supplies are imported, and will likely continue to be in the near future. Some geologists argue that large oil fields should exist in Brazil, but the final answer will depend on further exploration. The national government formed a state monopoly, Petrobras, one of the largest companies in the world, to import petroleum, handle the processing, and handle part of the distribution.

At one time the subsidy on gasoline and oil products was guite large. This has been eliminated. Barring serious balance of payment problems, the supply of gasoline and oil products will probably be adequate in the near future. It should pose no restrictions to the mechanization of agriculture, although the distribution system in the interior is not all that it might be.

Because of the lack of organic fuels, the country has depended heavily on wood as a fuel and source of energy. This wood is converted into charcoal close to the sources of supply, and is hauled long distances by truck to the steel mills and other users. This dependence on wood provides an important source of supplementary farm income in some parts of Brazil, and has led to a specialization in the growing of eucalyptus specifically for this purpose. Some of the steel mills have huge plantings in order to assure a stable supply. 
Brazil has tremendous potential for hydroelectric power which, until recently, was not fully exploited. In the last 10 years, however, an intensive program of dam and power plant construction has taken place. Even so, the supply is no more than keeping up with the demand. Seasonal droughts and floods result in power crises. As late as 1964, industry in São Paulo and Rio de Janeiro was working at less than full capacity because of power shortages. In addition, power was rationed to city dwellers and commerce.

Rural electrification is extremely limited, except in São Paulo. Larger farms buy their own power plants, which are generally powered by internal combustion engines. Smaller farmers use simple waterwheels as sources of power or use some form of animal power.

\section{Irrigation}

Very little has been done in the field of irrigation in Brazil, despite the rather large hydroelectric projects and the existence of large areas that could benefit from irrigation. As far as is known, no study or survey has been made of existing irrigation projects, nor of the capital invested in them. A number of plans exist for irrigation projects in the South, East, and Northeast, however.

Probably the most extensive areas under irrigation in Brazil are in the state of Rio Grande do sul, and this is primarily for rice production. For the 1959-1960 rice crop, a total of 293,753 hectares was irrigated. Of these, 200,458 hectares was by mechancial irrigation, 69,650 hectares by gravity irrigation, and 23,644 hectares by a combination of the two systems.

Some irrigation is used in São Paulo, and this is also primarily for rice and vegetable crops. Most of this is concentrated in the Paraiba Valley.

A number of regions have been selected for irrigation along the São Francisco River. The first project was to be a gravity irrigation project on the southern border of the Rio Grande and was to comprise 300,000 hectares when finished. The initial works, to irrigate 2,000 hectares, were progressing slowly. 
A more recent project is directly on the são Francisco River, near Petrolina. Rather large areas along the river which have irrigation potential, have been identified, and the water is to be pumped directly from the river. This project is being developed as a cooperative venture with the U.N. An experiment station has been installed for the study of production conditions, and a limited number of canals have been constructed. Land distribution on an experimental basis has only recently begun.

This project has a great deal of potential for improving the food situation in the Northeast. It is located close to the three main population centers of the Northeast, and roads are being constructed linking the irrigation area to these centers. The experimental results indicate that the region has tremendous production potential for a wide variety of products.

\section{NOTES}

1. See Vernon w. Ruttan, "Notes on Agricultural Product and Factor Markets in Southeast Asia," in Kurt R. Anschel et. al., eds., Agricultural Cooperatives and Markets (New York: Frederick A. praeger, 1969).

2. This aspect of markets was given special attention in a large research project on agricultural markets in Northeast Brazil conducted by Michigan state University. (For a summary report, see Charles slater, et. al., Market Processes in the Recife Area of Northeast Brazil, Research Report No. 2 (East Lansing, Mich.: Latin American studies Center, Michigan state University).

3. See CIDA, Land Tenure Conditions and SocioEconomic Development of the Agricultural Sector, Brazil (Washington, D.C.: Pan American Union, 1966).

4. For a contrasting view, see william $H$. Nicholls, and Ruy M. Paiva, Ninety-Nine Fazendos: The structure and Productivity of Brazilian Agriculture, 1963, prelim. (Nashville, Tenn.) 
5. For a recent study of the Latin American automotive industry see Bernard Munk, "The Welfare Costs of Content Protection: The Automotive Industry in Latin America," Journal of Political Economy, LXXVII, 1 (January/February, 1969), 85-98.

\section{Ibid.}

7. This material is drawn from Agri Research, Inc., Recommendations for Manufacture-Distribution of Agricultural Minerals in Brazil Manhattan, Kans.: (Agri Research, Inc.; Wichita, Kans.: Litwin Engineering Company, Inc., 1964). This publication is a valuable source of information on the fertilizer situation in Brazil. 


\section{CHAPTER \\ SOME OF THE MAJOR FACTOR'S AFEECTING AGRICULTURAL PROGRESS}

This chapter is divided into two parts. The first discusses the factors that are contributing to agricultural progress. The second discusses the factors inhibiting agricultural progress.

FACTORS CONTRIBUTING

TO AGRICULTURAL PROGRESS

The conditions and/or factors that are building points for the improvement of the agricultural sector are discussed in this section. Our vantage point is the present, with a look to the future. The objective is to identify those factors upon which Brazil can capitalize in modernizing its agricultural sector. The emphasis is on modernization and on raising factor productivity, not just increasing agricultural output. The latter can be done by expanding the area under cultivation. If the agricultural sector is to play the role that it can and should play in furthering the economic development of the country, however, productivity will have to be increased.

\section{A New, Favorable Attitude} Towards Agriculture

An important asset at this point in time is the improved attitude towards the agricultural sector. Both lay people and political leaders are beginning to recognize that agriculture is an important industry, that it will have to be modernized in order for Brazil to continue to grow, and that a policy which concentrates only on industrialization will not lead to self-sustaining growth. 
The most important policy steps have been the freeing up of agricultural prices, so that the farm sector is no longer discriminated against; the relaxation of export controls, so that a broader market is available; and the increase in credit extended to agriculture. Of a longer-run nature are the support for increased training of agronomos and the serious attempts which are being made to strengthen the colleges of agriculture through technical assistance programs. The enrollment in schools of agronomy has grown substantially from 1960 to the present, and this has required increased financial support.

We hasten to add, however, that the situation is far from being ideal on this point. The contribution that agriculture can make to economic development is not well understood, nor is the role that this sector has played in the past development of Brazil. The importance of raising productivity is not generally appreciated, nor is, the importance of research in doing so.

However, the changed attitude, which is really only a start in the right direction, can be utilized as a building block for further shifts in this direction. If utilized properly by political leaders, it can be a strong foundation stone in building a revitalized agriculture.

Greater Appreciation of Science and Technology

Brazil, with its rich Latin traditions, has not in the past had a strong scientific and technologi-. cal orientation. Although its architects are worldfamous, its engineers are much fewer in number and much less well-known.

This is changing. Increased interest is being shown in science and technology by university students. Attempts are being made to improve and expand technical training, and to strengthen scientific training. Science is playing a much more important role in primary and secondary education.

In addition, there is a growing recognition of the role of science and technology in economic development. This is apparently a trend throughout Latin 
America, and was perhaps epitomized at the 1967 meeting in Punta del Este, where the Latin American countries were almost unanimous in stressing the role of these two factors in further development efforts. This bodes well for obtaining future support for the agricultural research which is so badly needed.

\section{A More Rational General Economic Policy}

In addition to the shift in policy within the agricultural sector, the rationalization of general economic policy which has taken place can contribute to agricultural progress. Subsidies have been reduced and in many cases eliminated, inflation is being reduced, and the exchange rate has been brought closer to a true reflection of the value of the country's currency. This has reduced the distortions in the agricultural sector and the need for government interventions. A serious attempt is being made to collect taxes so that the budget can be balanced and taxation by inflation will no longer be needed.

These policies, although going much beyond the agricultural sector, have an important impact on it. The reduction of inflation will make for a more viable capital market, which agriculture badly needs. Subsidies of the past have in many cases worked against agriculture, and this discrimination is now reduced. The successive increases in the exchange rate, together with the elimination of prohibitions against exports, enable the agricultural sector to compete more effectively in world markets.

\section{More Well-Trained Technicians}

Enrollment in schools of agriculture has risen substantially, and the increased supply of agrónomos is already entering the economy. If the improved attitude towards agriculture can be translated into increased financial support for research, for extension, and for other technical assistance programs to the rural sector, this skilled manpower can make a significant contribution to the further development of agriculture. 
Equally important is the increased supply of technicians with graduate training. The development of graduate programs within Brazil has contributed greatly to this increased supply. The granting of $70 \mathrm{M} . \mathrm{S}$.'s in agricultural economics at Viçosa alone has substantially increased the number of people who can help in attaining more rational economic policy. The impact is equally great in the other agricultural disciplines.

The number of people working on $\mathrm{Ph} . \mathrm{D}$. programs has also increased, although these are only beginning to feed back into the economic stream. Once a critical mass has been assembled, domestic doctoral programs can be developed, and at least the human resources will be available for high-level research. It is imperative that these men be given the resources and environment in which they can effectively contribute to Brazil's economic development.

\section{The Beginning of a}

Research Infrastructure

We will argue below that the lack of agricultural research is a factor inhibiting agricultural progress. However, the fact that Brazil has a couple of reasonably strong research institutions, and a rather extensive system of experiment stations, is a positive factor in facilitating agricultural progress.

Given the system that is available, the upgrading of staff and the orientation of research programs along more relevant lines could lead fairly rapidly. to an increased stock of knowledge. The fact that many of the participants in the Brazilian graduate programs come from existing research institutions means that these men are already in positions where they can influence the course of events.

In addition, the output from these existing institutions shows what research can do. The new coffee varieties and cotton varieties in são Paulo have had a significant impact not only in são Paulo, but in other states as well. A new tomato variety developed at vicosa is being widely adopted by farmers. 
Hence, the development of a strong research infrastructure does not have to start at zero. The system is already in place, and in some cases the output has been significant. This should facilitate the strengthening of this sector.

\section{A Growing Industrial Sector}

The rapidly growing industrial sector can play two roles in fostering agricultural progress. First, it can absorb the labor that will be released from the agricultural sector as productivity in the latter sector rises. Although the record during the decade of the 1950's was not good, with improved manpower programs and perhaps a shift in the industrial mix to industries utilizing more unskilled labor, the performance could be improved.

Perhaps the more important role that the industrial sector can play is in supplying the new modern inputs that are necessary for a modern agriculture. Considerable know-how has been developed in Brazil's industrial sector. This could be applied to make the automobile industry a producer of tractors, machinery, and equipment. The chemical industry can expand into the production of fungicides and other pesticides. The development of a strong fertilizer industry should not be too difficult, given the availability of raw materials and the by-products of the existing petroleum and steel industries.

Developments in these directions would provide at least two positive contributions to the general economy, in addition to the direct contributions to the agricultural sector. They would eliminate the need to import these products, which places a strain on the balance of payments. Brazil's repayment problem is likely to be great in the future and will place considerable stress on the balance of payments.

In addition, these developments will provide an expanding market for the industrial sector. The past orientation towards import-substitution has led to an industrial sector with a very narrow market. This will need to be broadened if the industrial sector is to grow, and the production of inputs for the agricultural sector can be a very broadly based market. 
A Rich Endowment

of Natural Resources

Brazil has an abundant endowment of good soils. Although generally lacking in nutrients, large areas of level land with basically good structure are available. These lend themselves to a modern mechanized agriculture. In addition, adequate supplies of water are available in most of the country. Hence, the basis for a modern productive agriculture is at hand.

In addition to these factors, Brazil has a rich endowment of minerals of almost all kinds. It has one of the richest iron ore deposits in the world. Minerals for the manufacture of fertilizer and other chemical products are readily available, with the possible exception of potassium. Hence, there is no reason, from this standpoint, for Brazil to be hindered in the modernization of its agriculture.

\section{Examples within the country}

The demonstration effect is valuable in any learning situation. Brazil has some important examples of what a modern agriculture can be, and of what is necessary to attain it.

The state of São Paulo has a relatively modern agricultural sector. Modern practices are being used, and a recent studyl showed that total factor productivity in this state increased during the decade of the 1950 's at practically the same rate as. that in the United states.

In addition to the general conditions of this state, there are small isolated examples of modern agriculture. The production of tomatoes in são Paulo is carried out with a very high level of technology. Artificial insemination is being used in Rio Grande do Sul to upgrade beef herds. Broiler farms with high levels of technology are functioning near the larger cities.

In addition to these cases, there are demonstration effects from the institutions serving agriculture. Although the ABCAR extension system is rela- 
tively small, it has gained the support of rural people and rural leaders. The Instituto Agronbmico at Campinas has shown what a strong research institution can do. And UREMG at Viçosa has shown that graduate programs can be developed, and is in a position to show the advantages of integrating teaching, research, and extension.

\section{Conclusion}

Most of the factors cited here as fostering the modernization of agriculture are far from ideal in themselves. Each has serious limitations, and the situation could be much better. However, what one sees is that a start towards modernization has taken place. This start is a very valuable base upon which to build further improvement.

\section{FACTORS INHIBITING AGRICULTURAL PROGRESS}

The factors inhibiting agricultural progress are numerous. The ones discussed here are those thought to be the most important. No attempt is made to establish relative importance, although the strategies proposed later indicate indirectly the factors that we consider to be the most important. (See chapter 10.)

The elimination of no one of the factors discussed below would result in a modern agriculture. A broad-based approach which attempted to reduce the restrictions imposed by each could have a considerable impact.

\section{An Abundant supply of Land}

The specification of this as a factor inhibiting agricultural progress may take many by surprise. Most would probably argue that it is a factor facilitating progress.

If the objective were only one of increasing agricultural production, we would agree. But the point remains that agricultural progress involves the modernization of agriculture, with a rise in 
factor productivity. And modernization of agriculture will require large investments both in rural people and in research.

Such investments will be difficult to attain as long as Brazil has an abundant supply of land. As long as agricultural production can increase at about the same rate as the increase in demand by the mere occupation of more land, there will not be much incentive to invest in research and technology in the rural sector. Even though production moves farther from the consumption center, improvements in the transportation system can prevent the relative price of food products from rising significantly. And it requires a pretty sophisticated view to recognize that increasing productivity, which tends to lower food prices, can play a positive role in development.

It is interesting to note that the land grant colleges and the investments in agricultural research in the United States did not start until several years after the frontier had closed and relative food prices had begun to rise. It appears most likely that it will be difficult to obtain the public commitment for agricultural research in Brazil until a similar situation arises. The demands for developmental resources are great, and will continue to be so. The channeling of resources to research, which takes time to have an impact, will be difficult until some stress signals arise.

Such stress signals could come from a scarcity of labor, if the non-farm sector should aucceed in developing rapidly enough. The resulting rise in the price of labor would probably lead to the oubstitution of land for labor, however, with an increase in mechanization. It is not clear that this would raise total factor productivity.

\section{The Lack of Production Technology}

A few higher-yield varieties have been developed in Brazil, and the adoption of modern techniques of production has taken place in some areas. However, the lack of production technology is great.

Very little is known about tropical soils and how best to manage them. Very little is known about the response of these soils to fertilizer. The cap- 
ablitty for generating and developing new, higheryield varieties is limited. Little research has been done on ways of carrying cattle through the dry season. Little is known about the response of cattle to increased feeding rates, or about what optimum rations are. Little 18 known about what combinations of enterprises are most profltable. And little research has been done on troplcal diseases of either livestock or crops.

This list could go on. The point is that the research on agricultural problems in Brazil is quite limited, and the capability for a rapid expansion is not there.

An important point to recognize in this respect is that there are tremendous regional disparities in the research capability. The South is in a much better situation relative to the North. But even in the south, the research capabllity is not as large as it should be to sustain a modern agriculture.

The Northeast has an important portion of the Brazilian population. The level of technology in this region is quite low, and reflects the general lack of knowledge about tropical agriculture. However, the soll and climatic conditions in this region need not be a barrier if the production know-how can be generated.

Vast areas of Brazil's interior consists of cerrado solls. Little is known about them. Preliminary research suggests that they can be highly productive if soll deficiencies are corrected. But further development will depend on substantial investments in research.

An important resource in Brazil is the large herd of cattle. Yet the productivity in this eector is one of the lowest in the world. Despite the fact that livestock numbers appear to be increasing, production $1 \mathrm{~s}$ not increasing at the same pace as demand. Relative prices of meat products are rising, in a country which already consumes a low protein diet and in which protein deficiencies are serious among important groups of the populace. 


\section{A Low Rate of Human Investment}

Despite the strong efforts at raising educational achievement, the rate of human investment is still quite low, especially in rural areas. The prevalence of illiteracy among rural people is a serious impediment to modernizing the agricultural sector. And the educational attainment of the rural population, even at the lower levels, is much behind that of the urban population.

Secondary schooling is extremely limited, and higher education is still a rarity for most people in the society. Only recently have attempts been made to provide graduate training, and this is still on an extremely small scale.

The social returns to investments in education are well documented. These returns are especially high for the lower levels of eduçation. Until Brazil invests more heavily in her people, development will be a slow process.

\section{A Limited Extension Service}

Brazil has the beginning of an excellent extension service. However, the number of farmers reached with true extension services is still small, and in some states practically nil. An excessive amount of resources still goes into fomento, rather than into the training and education of rural people. The distribution of seeds, breeding stock, and tractor patrols, free, cannot be expected to have much of an impact until the farmer has an increase in knowledge, and perhaps a change of values.

An important factor inhibiting the further development of the extension service is the lack of production knowledge. In fact, it makes little sense further to strengthen the extension service until an expanded stock of new knowledge is available to extend. But enough knowledge is available in some areas that expanded extension programs can be effective. 
The Lack of Integration of Teaching, Research, and Extension

There is a high degree of complementarity in having these three functions integrated, although they don't necessarily have to be in the same administrative organization. Their lack of integration is reducing the payoff from expenditures on each of them.

Much of the past research has not been relevant because most researchers had little appreciation of the problems of farm people. Extension people have not always been apprised of the latest developments on the research front. And teaching has tended to be isolated from the other two functions. Substantial efforts will have to be made to integrate these three functions in order that maximum payoff can be obtained from the investments in this sector.

\section{Inadequate Input Markets}

The lack of an adequate infrastructure imposes serious limitations on the markets for agricultural inputs. For labor, there is little semblance of an employment service available. Hence, information on employment opportunities and supplies of labor are passed on in large part by word of mouth. The. consequences of this are sizable discrepancies among wage rates and income levels, and poor utilization of labor, both within the agricultural sector and between the agricultural and non-farm sectors.

The market for land is not well organized. Perhaps the most serious problem here is the prevalence of internal and external credit rationing, which prevents land from being utilized by those who might be most able to do so and leads to soil exploitation in an attempt to meet repayment terms.

A market system for handling new, modern inputs has begun to develop in the southern part of the country. If profitable new technology is developed, and farm people begin to adopt it, the input market system will have to be expanded significantly. 
The differences in relative prices are approximately the same for the other plant nutrients. Hence, an important reason for the failure to adopt fertilizer is that it is a relatively expensive input. This is further reflected in the fact that fertilizer is used for some products, and not for others. A common response of the farmer who fertilizes one crop and not another, when queried as to why he doesn't fertilize both, is "näo compensa"-"it doesn't pay."

An important problem related to this situation is the inappropriate policy followed by many extension services. Recognizing that fertilizer is an important aspect of increasing productivity, they quite frequently undertake intensive campaigns to encourage the use of fertilizers by farmers in their state. If this is not a profitable undertaking, such campaigns are seriously misguided, and can lead to a discrediting of the extension organization. An important point here is that very little is known about the response of crops to fertilizer under Brazilian conditions, or about the complementarities that exist among fertilizer nutrients and between fertilizer and plant varieties.

Fertilizer is not the only modern input which has a high relative price. A medium-size tractor in Brazil in 1965 cost the equivalent of approximately 150 months' wages of a "minimum wage" worker. In the United States a similar tractor cost the equivalent of approximately 18 months' wages of a farm worker, even though the cost of labor is much higher in the latter case. Little wonder that so little mechanization takes place in Brazil. There is little incentive to mechanize when the price of labor is so cheap relative to capital items.

An unfortunate aspect of the "liberalization" of the external market in the period after 1964 was a rise in the price of such inputs. This came about because most of the modern inputs are imported; and the exchange rate was permitted to rise during this period, making the price of imported products more expensive. As an example of the impact, from 1964 to 1965 , the prices of fertilizers increased 3.4 times (in current values), the prices of insecticides and fungicides 2.2 times, and the price of the prin- 
cipal inputs used in agriculture lexcluding land and labor) 2.2 times. In the same interval, the price of agricultural products increased only 1.5 times.

This rationalization of the external market was a necessary step in putting the economic house in order. On the other hand, it stresses the importance of developing supply industries in Brazil, especially in those cases where the raw materials and the industrial base are available.

\section{A Deficient Credit Policy}

Although the question of whether an adequate supply of credit has been made available to agriculture is at least debatable, it appears that the credit policy has been deficient in a number of respects. The restrictions on interest rates lead to non-economic allocation of the limited supply of credit, and hence it does not in general go to those who are most able to make use of it. In addition, the bulk of the credit is of a ghort-term nature. This provides little incentive to upgrade livestock herds, undertake soil development practices, and make other investments of a longer-term nature. These are the kinds of investments necessary for increasing productivity.

In addition, an adequate market for long-term credit could facilitate the acquisition of land by small producers and help in obtaining a less skewed distribution of land holdings. For the development of such a market, however, it will be necessary either to stop inflation or to develop credit instruments that take account of the depreciation in the currency.

\section{An Inadequate Transportation System}

Although considerable progress is being made in developing an intra-national system of trunk highways, much remains to be done. Adequate farm-tomarket roads are still a serious problem in large parts of Brazil, and large areas still do not have adequate penetration roads.

What is perhaps more serious, however, is the lack of an adequate rail system to haul bulk commodities long distances, the very inefficient water 
transportation system, especially along Brazil's long coastline, and the inadequate and inefficient ports. until these deficiencies are reduced, Brazil will not be able effectively to exploit the external market which can be so valuable to it, nor will it be able effectively to integrate the southern and northern parts of the country and thereby eliminate the large regional disparity in income levels.

\section{Inflation}

Inflation has been reduced substantially from the rate of over 100 percent per year in the early part of 1964. The rate of inflation stabilized at about 25 percent in 1967 and 1968. Serious attempts are being made to bring it down still further in 1969. But inflation remains a serious problem in modernizing the rural sector.

The impact of inflation is manifold. It leads to disorganized capital markets and inhibits the development of the multiplicity of instruments necessary to have an adequate capital market. It leads to a confused pricing structure, especially in view of the very uneven rates of inflation. Production decisions almost always turn out to be wrong ex poste. And finally, it leads to serious distortions in the investment mix. Asset holdings are oriented towards protecting the purchasing power of the resources, and not necessarily towards those investments with the highest rates of social return.

\section{The Lack of Economic Policy Research}

Government intervention in the market is quite extensive in Brazil. Yet little attempt has been made to develop a research base that could make these interventions more rational and more helpful in attaining a rapid rate of economic growth. The result has been the pursuit of some very unwise economic policies, with little recognition of the serious consequences which they have.

An important corollary of this situation is the lack of adequate data upon which to base policy analyses. The national data service installed some time ago was probably too ambitious for the human and fi- 
nancial resources available in the country. The result has been a gradual deterioration in the quality of the data, especially as inflation eroded the salary scale of technicians employed in this sector.

A rational economic policy will be dependent in part on obtaining improved economic data. This will require a considerable reorganization of the existing system, with increased dependence on modern sampling theory rather than the present attempt to obtain complete enumeration.

\section{Fragmentation and Proliferation of Support Institutions}

Many pub'lic organizations and institutions exist for the provision of services to agriculture. In the state of Ceará alone, it has been estimated that there are 77 different agencies working with agriculture.

This proliferation and fragmentation of government agencies leads to ineffective use of the already scarce talent and developmental resources, and dilutes the rather substantial efforts to "help" the agricultural sector. A streamlining and reform of the governmental system will make for a much more effective utilization of the scarce technical and administrative talent which Brazil has.

\section{Discrimination Against Agriculture}

Considerable progress has been made in recent years in attaining a more favorable attitude towards agriculture. However, discrimination against this sector has been an important factor holding it back in the past. Only limited efforts were made to invest in developing agriculture or in making it a productive part of the economy. Rather, the approach was more one of exploiting it and taking from it in order to develop a strong industrial sector.

It is hoped that the new attitudes will continue, and that major steps will be taken to modernize this important sector of the economy. Unless this is done, its potential will not be realized. 
348

THE AGRICULTURAL DEVELOPMENT OF BRAZIL

NOTES

1. Oscar J. T. Ettori, "Productividade Física da Agricultura em são Paulo," Agricultura em São Paulo, XI, 7 (July, 1964), 3-4.

2. Ruy M. Paiva, "Reflexos SBbbre as Tendências da Producão, da Produtividade e dos Preços do Setor Agricola do Brasil," Revista Brasileira de Economia (September, 1966). Also available in English. 
CHAPTER

PROJECTIONS FOR

AGRICULTURE, 1960-1975

This chapter presents projections of the demand and supply of agricultural products for the years 1970 and 1975 . They include estimates of domestic demand and supply, as well as estimates of exports and imports. In order to make these projections, it was necessary to make projections concerning input use and, at least in the case of labor, some projection of changes in labor productivity. These assumptions will be made explicit at the appropriate places.

Projections into the future for a country as large and diverse as Brazil are at best tenuous. Moreover, in a very real sense such projections are made in order to be wrong. Their basic objective is to provide insights into what is possible, or into what will happen if events continue to unfold as they have in the past, or as they are expected to unfold. If the projections should identify serious problems that are likely to occur in the future, both public and private decisions may well alter what actually happens and make the projections wrong. In addition, the projections are useful for showing potential, and in a sense serve as a bench mark against which the consequences of policy measures can be evaluated.

The material presented in this chapter is drawn directly from a study made by FGV. 1 The study was the result of a contract with the U.S. Department of Agriculture, and had as its objective the preparation of projections of demand and supply for 18 of the principal agricultural products.

The projections attempt to account for substitution possibilities on both the demand side and the supply side. Demand projections are based on a rather large family budget survey which provided rather detailed starting points for the analysis. Income elasticities and projections of income, 
population, and population shifts were used in making the projections. A macro-economic model was developed in order to project income.

On the supply side, technical production functions were estimated by product and by state for the principal products. The production functions, plus projections of resource use, were used to make the projections, although in some cases the question was reversed and the change in input needed (capital) and the change in productivity necessary (labor) were evaluated.

The import and export projections evolve from the basic demand and supply analyses. An attempt was made to asess the role that government policy would play in restricting. both exports and imports of agricultural products.

At each step in this chapter an attempt is made to explain the methodology used in sufficient detail that the reader can evaluate the projections obtained. More detail on the procedures and the underlying data can be obtained from the original document.

\section{POPULATION GROWTH}

Since there are no official projections of population for Brazil, the Vargas group had to develop their own. Only one set of projections was made, but this set has a reasonable degree of detail. Estimates were made of both the urban and the rural populations by age groups, which permitted the maximum use of information obtained from the family budget studies.

Projections by age group were made for 1965 , 1970, and 1975. (The estimates were based on 10year survival rates and a constant gross birth rate of 43 per 1,000. The birth rate was found to have been reasonably stable between 1872 and 1950 , and hence was projected as unchanging.) The total of these gave estimates of the total population. The distribution between the rural and urban sectors was done in two steps. Since rural population grew at a rate of 1.6 percent a year for the decades of 
TABLE 113

Population Projections, by Sector and Age Group, 1965, 1970 and 1975 (in thousands)

\begin{tabular}{|c|c|c|c|c|c|c|c|c|c|c|c|}
\hline Age & \multicolumn{2}{|c|}{ Group } & \multicolumn{2}{|r|}{$\begin{array}{l}\text { Total } \\
1970\end{array}$} & 1975 & \multicolumn{2}{|r|}{$\begin{array}{r}\text { Urban } \\
1970\end{array}$} & 1975 & 1965 & $\begin{array}{r}\text { Rural } \\
1970\end{array}$ & 1975 \\
\hline $\begin{array}{r}0 \\
5 \\
10 \\
15 \\
20 \\
25 \\
30 \\
40 \\
50 \\
60 \\
70 \\
80\end{array}$ & $\begin{array}{l}\text { to } 4 \\
\text { to } 9 \\
\text { to } 14 \\
\text { to } 19 \\
\text { to } 24 \\
\text { to } 29 \\
\text { to } 39 \\
\text { to } 49 \\
\text { to } 59 \\
\text { to } 69 \\
\text { to } 79 \\
\text { years }\end{array}$ & $\begin{array}{l}\text { years } \\
\text { years } \\
\text { years } \\
\text { years } \\
\text { years } \\
\text { years } \\
\text { years } \\
\text { years } \\
\text { years } \\
\text { years } \\
\text { years } \\
\text { and over }\end{array}$ & $\begin{array}{r}13,650 \\
12,611 \\
9,316 \\
8,445 \\
6,984 \\
6,062 \\
10,136 \\
6,905 \\
4,116 \\
2,140 \\
917 \\
364\end{array}$ & $\begin{array}{r}15,930 \\
14,732 \\
11,000 \\
10,465 \\
7,803 \\
6,740 \\
11,469 \\
8,243 \\
4,731 \\
2,484 \\
1,032 \\
444\end{array}$ & $\begin{array}{r}18,600 \\
17,216 \\
12,995 \\
12,976 \\
8,721 \\
7,498 \\
12,984 \\
9,845 \\
5,440 \\
2,883 \\
1,161 \\
542\end{array}$ & $\begin{array}{r}6,301 \\
5,771 \\
4,395 \\
4,089 \\
3,608 \\
3,252 \\
5,488 \\
3,765 \\
2,266 \\
1,197 \\
517 \\
204\end{array}$ & $\begin{array}{r}7,970 \\
7,316 \\
5,606 \\
5,455 \\
4,302 \\
3,840 \\
6,589 \\
4,770 \\
2,757 \\
1,468 \\
613 \\
264\end{array}$ & $\begin{array}{r}9,444 \\
9,145 \\
7,060 \\
7,189 \\
5,076 \\
4,494 \\
7,837 \\
5,981 \\
3,325 \\
1,785 \\
723 \\
336\end{array}$ & $\begin{array}{r}7,349 \\
6,840 \\
4,921 \\
4,356 \\
3,376 \\
2,810 \\
4,648 \\
3,140 \\
1,850 \\
943 \\
400 \\
160\end{array}$ & $\begin{array}{r}7,960 \\
7,416 \\
5,394 \\
5,010 \\
3,501 \\
2,900 \\
4,880 \\
3,473 \\
1,974 \\
1,016 \\
419 \\
180\end{array}$ & $\begin{array}{r}8,656 \\
8,071 \\
5,935 \\
5,787 \\
3,645 \\
3,004 \\
5,147 \\
3,864 \\
2,115 \\
1,098 \\
438 \\
206\end{array}$ \\
\hline Tot & tal & & 81,646 & 95,073 & 110,861 & 40,853 & 50,950 & 62,895 & 40,703 & 44,123 & 47,996 \\
\hline
\end{tabular}

Source: Projections of Supply and Demand for Agricultural Products of Brazil Through 1975 (Rio de Janeiro: IBRE, FGV, 1968). (Hereafter cited as Projections of Supply and Demand.) 
1940-1950 and 1950-1960, this rate was projected through the period of analysis. This led to the following percentages of rural population of the total: 1960, 53.7 percent; $1965,49.9$ percent; 1970, 46.4 percent; and 1975, 43.1 percent.

With this as the basic data, the breakdown by age group was modified by known information about the rate of migration of specific age groups. This resulted in age-group projections for the total population and the rural population. The projections for the urban population were then computed by subtracting the rural population, by age group, from the total--also by age group.

The results of these projections are presented in Table 113. They indicate a somewhat smaller growth rate in the total population between 1970 and 1975 than has been experienced in the recent past (about 2.8, compared with 3.0). Rural population is assumed to continue increasing at the same rate as it has in the past, and the shift to urban areas is assumed to continue.

\section{DOMESTIC PRODUCT AND \\ PERSONAL DISPOSABLE INCOME}

Projections of real income were made from a Harrod-Domar-Ichimura-type model. Alternative projections were made on the basis of minimum and maximum values for the parameters of the model, with these minima and maxima chosen to be consistent with past rates attained. The result was four separate projections of the rates of growth in real product. A geometric average of these was taken and the result, a growth rate of 6.3 percent in gross real income, was used as the basis of the demand projections. This projected rate of growth was checked by making an alternative estimate based on the projection of labor force by sectors and the projection of trends in productivity by sector. The result from this alternative approach was very close to the above projection ( 6.2 percent), and gives some confidence in it.

The national income was then allocated among sectors based on the proportions existing in 1960. Disposable income was estimated from a regression 
equation relating disposable income and gross national income for the period 1947-1960. The distribution of disposable income among sectors was based on the assumption that direct taxes would fall only on urban incomes. The resulting projected rates of growth of real disposable income are presented in Table 114 .

\section{TABLE 114}

Projected Rates of Growth in Real

Disposable Income, to 1975

(average annual geometric rate)

Specification

Rate

Disposable Income, Private Sector

6.48

Disposable Income, Rural Sector

3.58

Disposable Income, Urban Sector

7.28

Source: Projections of Supply and Demand. 


\section{DEMAND}

\section{Consumption Levels}

The estimates of consumption levels are based on two studies made by the FGV in 1962-1963. One of these dealt with the rural population and the other with the urban population.

For the urban group, estimates of the consumption of the principal products are in per capita terms. For the rural group, the estimates are based on adult units of consumption, which permits projections on the basis of age groups in the pyramid. For the rural population, corrections were also made for meals consumed outside the household and for meals consumed within the household by outsiders.

In both cases adjustments were made to the year 1960, since this was chosen as a starting point for the projections. Per capita consumption was adjusted by the estimated income elasticities and the observed changes in per capita disposable income.

In order to facilitate comparisons between the rural and urban areas, and with other countries, these data were converted to per capita terms for both sectors and measured in terms of primary products. Substantial differences can be seen between the urban and rural consumption patterns. First, products that are imported or that require considerable processing are consumed at much lower rates among the rural population. Thus, the per capita consumption of wheat in rural areas is only half that in urban areas. The consumption of processed meats is almost unknown in rural areas, and the consumption of vegetable oils is comparatively low. Products such as potatoes, which are produced primarily in the southern part of the country, are consumed at a higher rate among the urban population, as are oranges. 
TABLE 115

Annual Per Capita Consumption of

Primary Products in Urban and

Rural Sectors, 1960

\begin{tabular}{|c|c|c|c|}
\hline Specification & Urban & Rural & General \\
\hline Rice & 38.4 & 40.3 & 39.4 \\
\hline Corn ${ }^{a}$ & 4.0 & 29.6 & 17.6 \\
\hline Wheat $^{a}$ & 57.5 & 31.3 & 43.6 \\
\hline Edible Beans (f́eijão) & 19.6 & 34.8 & 28.0 \\
\hline Potatoes & 14.8 & 7.9 & 11.0 \\
\hline Mandioca ${ }^{\mathbf{a}}$ & 40.0 & 199.6 & 124.6 \\
\hline Beef & 30.9 & 15.5 & 23.0 \\
\hline Pork & 1.9 & 11.1 & 6.8 \\
\hline Mutton, Goat & 0.3 & 4.0 & 2.3 \\
\hline Milk & 91.5 & 97.0 & 94.1 \\
\hline Poultry & 2.8 & 5.4 & 4.0 \\
\hline Eggs & 4.5 & 3.3 & 3.9 \\
\hline Fish & 5.8 & 3.6 & 4.6 \\
\hline Processed Meats & 2.1 & -- & 1.0 \\
\hline Bananas $^{a}$ & 22.1 & 28.3 & 25.4 \\
\hline Oranges & 37.1 & 20.5 & 28.3 \\
\hline Lard & 3.8 & 5.3 & 4.6 \\
\hline Bacon & 3.5 & 4.3 & 3.9 \\
\hline Vegetable Oils & 5.7 & 1.0 & 3.3 \\
\hline Coffee & 7.4 & 7.4 & 7.4 \\
\hline Sugar & 30.8 & 40.0 & 35.7 \\
\hline
\end{tabular}

${ }^{\text {a }}$ Data on apparent consumption were used in the projections instead of those here indicated. The former can be found in Table 116 under "Food Balance."

Source: Projections of Supply and Demand. 
The difference in source of protein is also substantially different between the rural and urban populations. The rural population is much more dependent on edible beans (feijăo), a vegetable sourc of protein. Even within the animal categories, the mix is substantially different. The urban population, with its higher income levels, consumes relatively more beef. The rural population consumes relatively more pork, mutton, goat, and poultry.

Not all of the data presented in Table 115 were used as the basis of the projections which follow. Serious discrepancies arose between these data and those from other sources. For example, the consumption of bananas and sugar is greatly different from that in a food balance analysis, which provides estimates of apparent consumption. The latter data were used for projection purposes, on the assumption that a substantial portion of these products goes for the industrial manufacture of sweets, which were not picked up in the family budget studies.

Similar considerations apply in the estimation of corn and mandioca consumption. The differences in this case were attributed to the use of these products for animal production. (Corn consumption appears to be underestimated by the family budget studies, and mandioca appears to be overestimated.) Once again, consumption rates were taken from estimates of apparent consumption, computed from food balance analyses.

And finally, apparent consumption estimates were used for wheat. The difficulty here comes from the indirect ways in which wheat flour is utilized, which makes the family budget estimates unreliable. Since 80 percent of the wheat is imported, and import-export data tend to be more reliable than others. the estimates used in projections were based on the apparent consumption.

The per capita consumption data estimated from the family budget estimates are felt to be more reliable and, in addition, facilitate the breakdown to urban and rural populations.

\section{Income Elasticity of Demand}

The Engel coefficients, calculated from the family budget studies, are presented in Tables 117 
TABLE 116

\section{Alternative Estimates of Food} Consumption, by Product, (Kg. per capita per year)

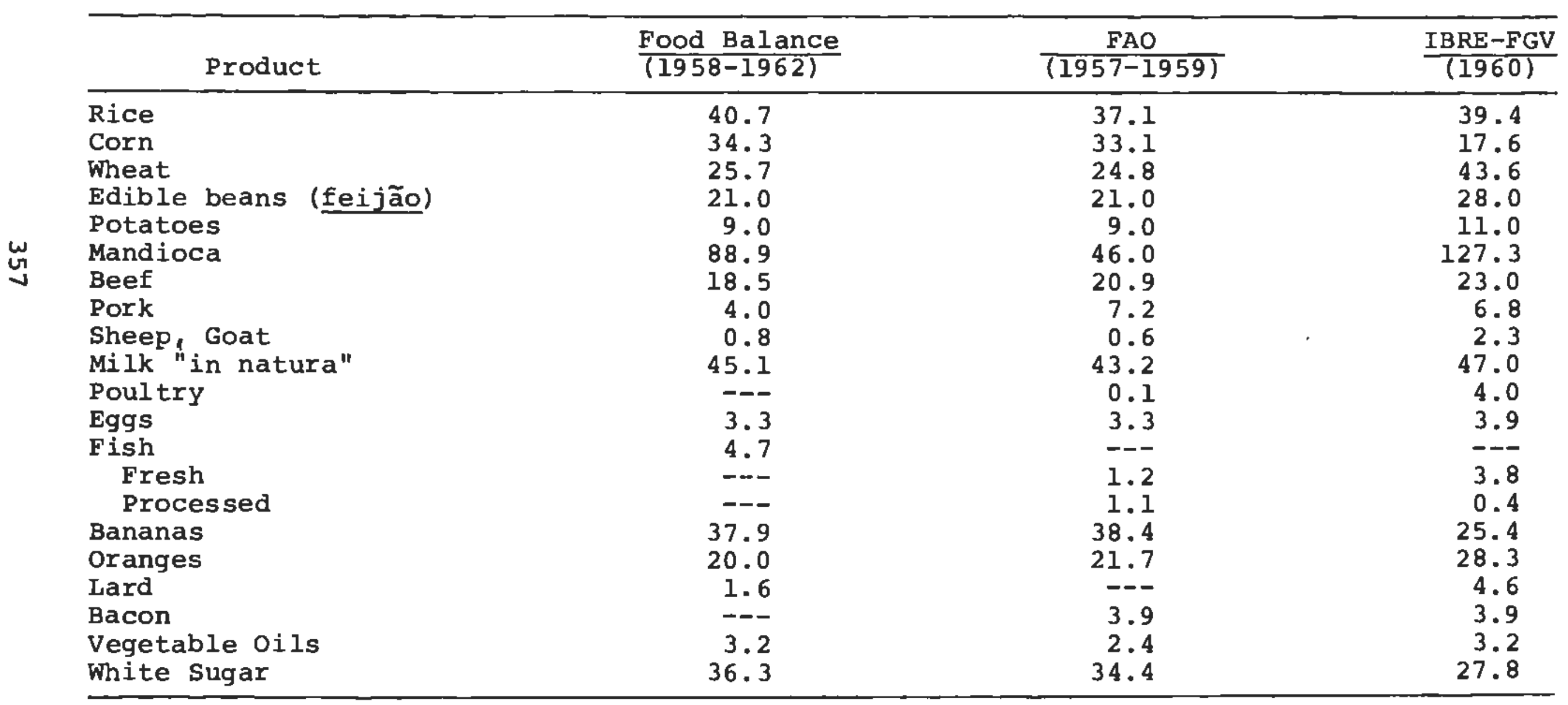

Source: Projections of Supply and Demand. 
TABLE 117

Engel Coefficients and Income per Capita,

urban Population

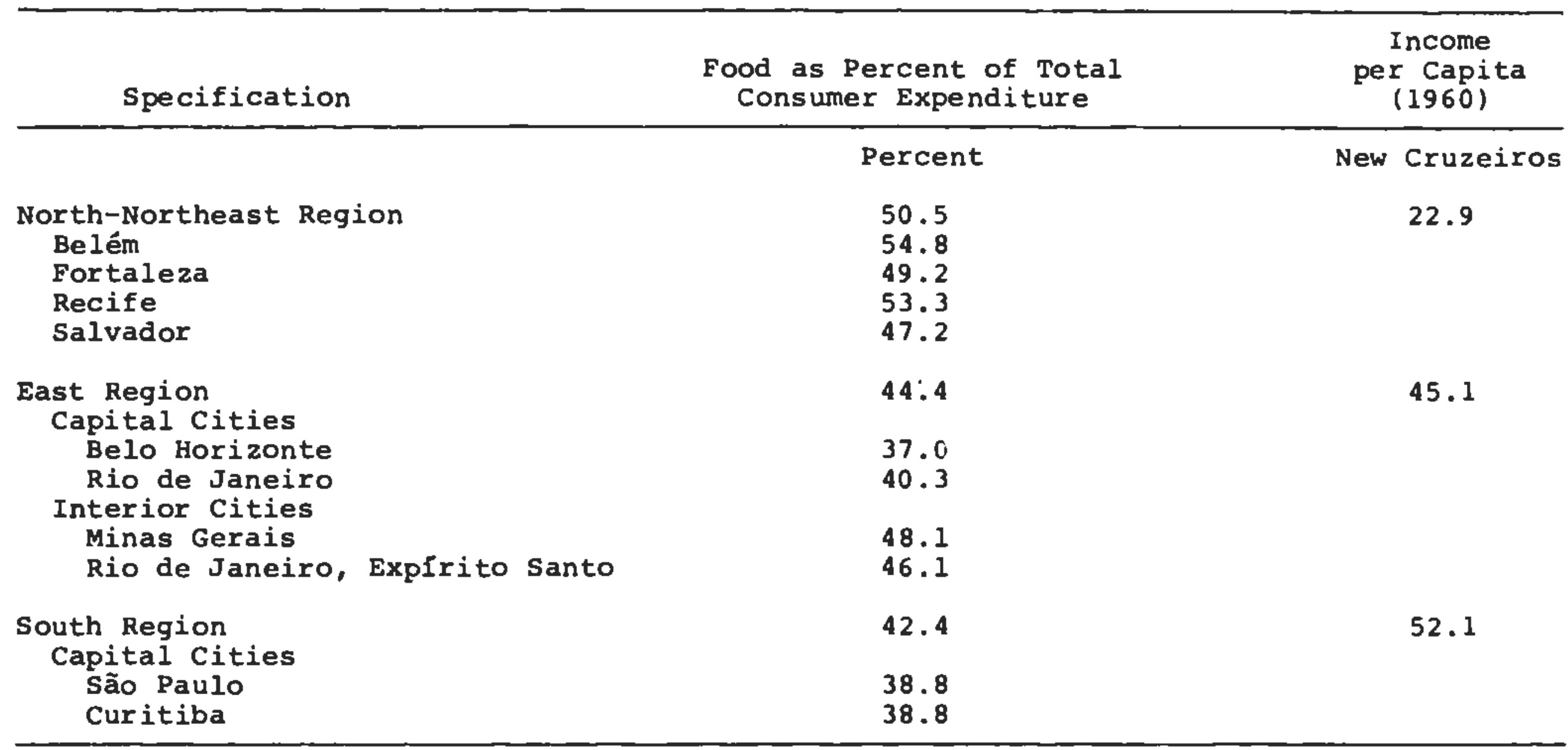




\begin{tabular}{|c|c|c|}
\hline Specification & $\begin{array}{c}\text { Food as Percent of Total } \\
\text { Consumer Expenditure }\end{array}$ & $\begin{array}{l}\text { Income } \\
\text { per Capita } \\
(1960)\end{array}$ \\
\hline & Percent & New Cruzeiros \\
\hline $\begin{array}{l}\text { Interior Cities } \\
\text { são Paulo } \\
\text { Paraná, Santa Catarina }\end{array}$ & $\begin{array}{l}44.5 \\
44.0\end{array}$ & \\
\hline Brazil & 45.2 & 40.3 \\
\hline
\end{tabular}

Source: Projections of Supply and Demand. 
TABLE 118

Engel Coefficients and Income per Capita Rural Population

\begin{tabular}{lcc}
\hline Specification & $\begin{array}{c}\text { Food as Percent of Total } \\
\text { Consumer Expenditure }\end{array}$ & $\begin{array}{c}\text { Income } \\
\text { per Capita } \\
(1960)\end{array}$ \\
\hline Northeast Region & Percent & New Cruzeiros \\
Ceará & 64.5 & 9.5 \\
Pernambuco & 62.4 & \\
East Region & 64.8 & 15.6 \\
Minas Gerais & 60.4 & \\
Espírito Santo & 59.3 & 26.4 \\
South Region & 61.4 & \\
São Paulo & 56.1 & 16.8 \\
Santa Catarina & 56.1 & \\
Rio Grande do Sul & 55.3 & \\
Brazil & 56.9 & 58.8 \\
\hline
\end{tabular}

Source: Projections of Supply and Demand. 


\section{TABLE 119}

Aggregate Potential Demand for Agricultural Products, 1960-1975

\begin{tabular}{lcc}
\hline Year & Million NCr\$ & Index \\
\hline 1960 & 1,526 & 100.0 \\
1965 & 1,842 & 120.7 \\
1970 & 2,241 & 146.9 \\
1975 & 2,763 & 181.1 \\
\hline
\end{tabular}

\section{a 1962 prices.}

Source: Projections of Supply and Demand. 
TABLE 120

Potential Demand, Urban Population, 1960-1975

(thousand metric tons)

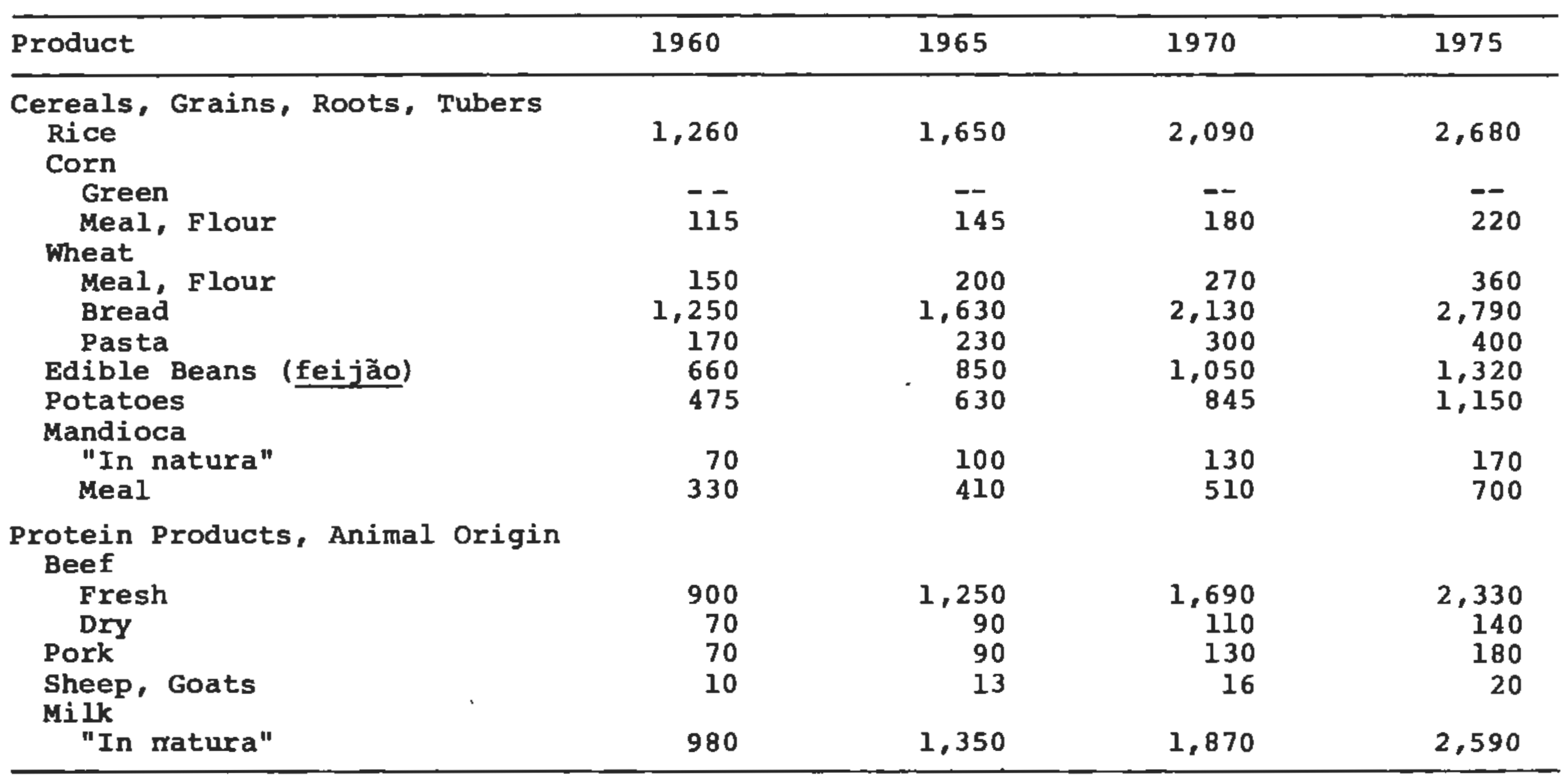




\begin{tabular}{|c|c|c|c|c|}
\hline Product & 1960 & 1965 & 1970 & 1975 \\
\hline \multicolumn{5}{|l|}{ Milk } \\
\hline Powdered & 45 & 60 & 80 & 100 \\
\hline Cheese & 60 & 85 & 125 & 185 \\
\hline Butter & 55 & 80 & 120 & 170 \\
\hline Poultry & 80 & 115 & 180 & 260 \\
\hline $\begin{array}{l}\text { Eggs } \\
\text { Fish }\end{array}$ & 270 & 200 & 280 & 375 \\
\hline Fresh & 135 & 190 & 260 & 355 \\
\hline Processed & 30 & 45 & 60 & 85 \\
\hline \multicolumn{5}{|l|}{ Fruits } \\
\hline Bananas & 860 & 1,150 & 1,495 & 2,010 \\
\hline Oranges & 1,200 & 1,680 & 2,320 & 3,204 \\
\hline \multicolumn{5}{|l|}{ Fats, Oils } \\
\hline Lard & 120 & 150 & 185 & 225 \\
\hline Bacon & 110 & 140 & 180 & 225 \\
\hline Vegetable & 200 & 275 & 372 & 499 \\
\hline \multicolumn{5}{|l|}{ Other } \\
\hline \multicolumn{5}{|l|}{ Sugar } \\
\hline White & 1,000 & 1,300 & 1,690 & 2,200 \\
\hline Raw Brown & -2 & - & -- & -- \\
\hline Molasses & -- & -- & -- & -- \\
\hline Coffee & 500 & 650 & 850 & 1,080 \\
\hline
\end{tabular}

Source: Projections of Supply and Demand. 
TABLE 121

Potential Demand, Rural Population, 1960-1975

(thousand metric tons)

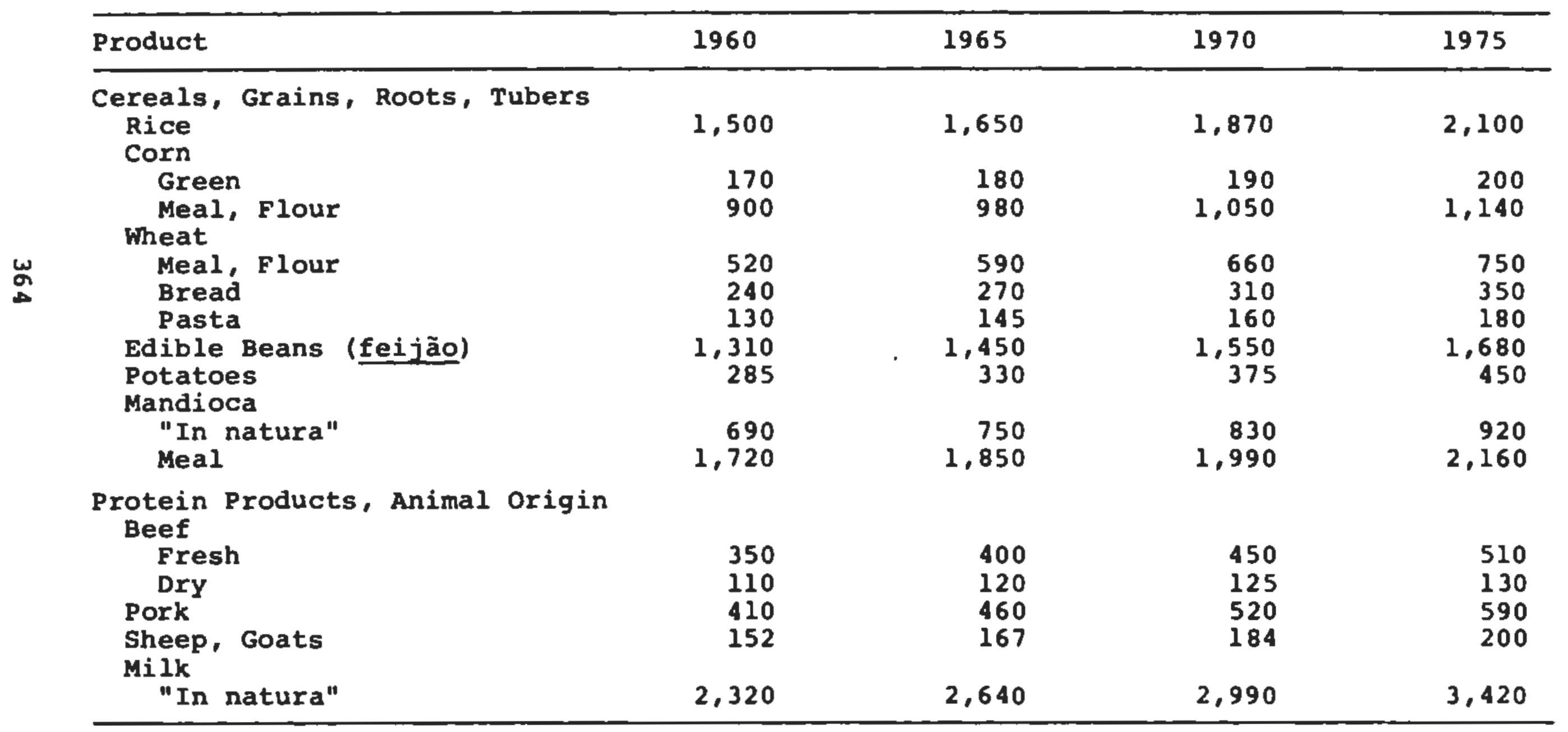




\begin{tabular}{|c|c|c|c|c|}
\hline Product & 1960 & 1965 & 1970 & 1975 \\
\hline \multicolumn{5}{|l|}{ Milk } \\
\hline Powdered & 17 & 18 & 19 & 21 \\
\hline Cheese & 75 & 87 & 100 & 117 \\
\hline Butter & 23 & 28 & 33 & 40 \\
\hline Poultry & 200 & 225 & 250 & 280 \\
\hline Eggs & 125 & 140 & 160 & 185 \\
\hline \multicolumn{5}{|l|}{ Fish } \\
\hline Fresh & 130 & 140 & 155 & 170 \\
\hline Processed & - & -- & -- & -- \\
\hline \multicolumn{5}{|l|}{ Fruits } \\
\hline Bananas & 920 & 1,000 & 1,120 & 1,230 \\
\hline Oranges & 750 & 860 & 970 & 1,110 \\
\hline \multicolumn{5}{|l|}{$\begin{array}{c}\text { Fats, Oils } \\
\text { Animal }\end{array}$} \\
\hline Lard & 200 & 220 & 245 & 275 \\
\hline Bacon & 160 & 175 & 190 & 215 \\
\hline Vegetable & 40 & 45 & 50 & 55 \\
\hline \multirow{2}{*}{\multicolumn{5}{|c|}{$\begin{array}{l}\text { Other } \\
\text { Sugar }\end{array}$}} \\
\hline & & & & \\
\hline White & 950 & 1,050 & 1,160 & 1,300 \\
\hline Raw Brown & 425 & 460 & 500 & 540 \\
\hline Molasses & 130 & 115 & 95 & 70 \\
\hline Coffee & 550 & 600 & 650 & 720 \\
\hline
\end{tabular}

Source: Projections of Supply and Demand. 
TABLE 122

Potential Demand, Total Population, 1960-1975

(thousand metric tons)

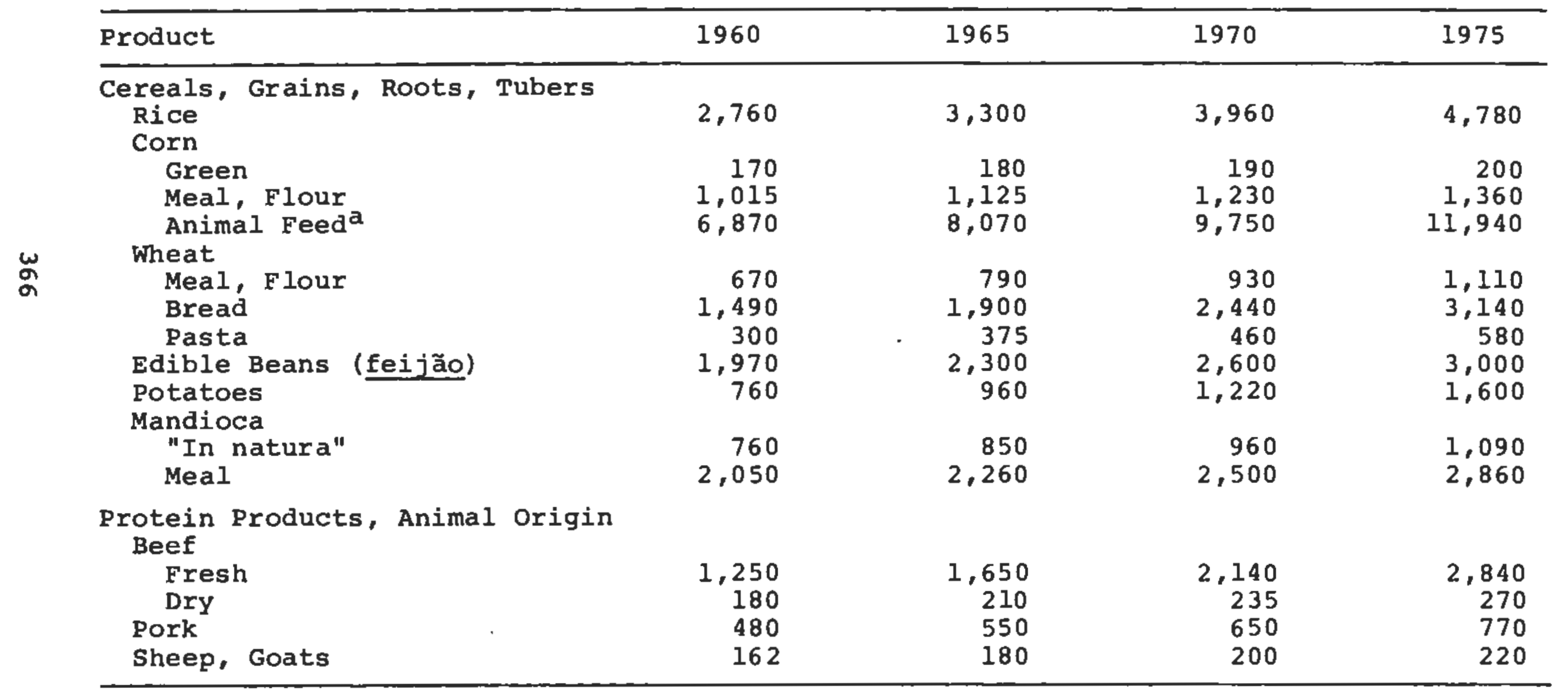




\begin{tabular}{|c|c|c|c|c|}
\hline Product & 1960 & 1965 & 1970 & 1975 \\
\hline \multicolumn{5}{|l|}{ Milk } \\
\hline "In natura" & 3,300 & 3,990 & 4,860 & 6,010 \\
\hline Powdered & & & 99 & 121 \\
\hline Cheese & 135 & 172 & 225 & 302 \\
\hline Butter & 78 & 108 & 153 & 210 \\
\hline Poultry & 280 & 340 & 430 & 540 \\
\hline Eggs & 270 & 340 & 440 & 560 \\
\hline \multicolumn{5}{|l|}{ Fish } \\
\hline Fresh & 265 & 330 & 415 & 525 \\
\hline Processed & 30 & 45 & 60 & 85 \\
\hline \multicolumn{5}{|l|}{ Fruits } \\
\hline Bananas & 1,780 & 2,150 & 2,615 & 3,240 \\
\hline For Production of Sweets ${ }^{a}$ & 880 & 1,190 & 1,625 & 2,260 \\
\hline Oranges & 1,980 & 2,540 & 3,290 & \\
\hline \multicolumn{5}{|l|}{ Fats, Oils } \\
\hline \multicolumn{5}{|l|}{ Animal } \\
\hline Lard & 320 & 370 & 430 & 500 \\
\hline Bacon & 270 & 315 & 370 & 440 \\
\hline Vegetable & 244 & 320 & 422 & 554 \\
\hline \multicolumn{5}{|l|}{ Other } \\
\hline \multicolumn{5}{|l|}{ Sugar } \\
\hline White & 1,950 & 2,350 & 2,850 & 3,500 \\
\hline Raw Brown & -- & -- & -- & -- \\
\hline Molasses & -- & -- & -- & -- \\
\hline Coffee & 1,050 & 1,250 & 1,500 & 1,800 \\
\hline
\end{tabular}

${ }^{a}$ Calculated as a residual of the total demand.

Source: Projections of Supply and Demand. 
and 118. As is to be expected, the Engel coefficients are related to the level of income, with higher-income regions spending a smaller fraction of their budget on food items.

The estimates of income elasticities used in making the projections proceeded by steps. First, the cross-sectional sample data were used to estimate income elasticities by products from rural and urban samples. Weighted regression procedures were used in this to account for the different sampling rates among income strata. The demand projections were then made on the basis of these coefficients, with separate elasticities used for the rural and urban populations.

Then, a new function was fitted to these data which permitted a variable elasticity and in which the annual per capita consumption was regressed on weighted per capita income of the total population. This produces what is called a long-run potential income elasticity, which is different for each year and reflects the changing per capita consumption in the rural and urban populations. It also accounts for the substitutions which take place as migration occurs from the rural to the urban areas. (The elasticities may be obtained from the original source.)

\section{Projections of Potential Demand}

The projections correspond to a concept of potential demand in which relative prices are assumed to be unchanged, as are the physical conditions of supply. Combining the population projections, the estimated income elasticities, and the projections of income, demand projections were produced at two levels: aggregate and individual.

The aggregate demand calculated at 1962 prices and projected to the future is presented in Table 119. The projections indicate a geometric rate of growth of 4.04 percent to the year 1975. The difference between this and the rate of population increase is the amount due to rise in per capita incomes.

Tables 120-122 contain the projections according to product, and by population sector. In order 
to put these on the same base as the supply projections which are to follow, they were converted to primary product equivalents by the use of appropriate coefficients of industrialization. To this were added consumption for seed, eggs for incubation, consumption for animal feeding, and a margin for loss between farm and consumer. The resulting estimates are presented in Table 123.

For some of the projections in Table 123, alternative methodologies were used for export products and for products that serve as raw materials for industry. In the case of cocoa and cofee, domestic demand was estimated from the family budget studies, but external demand (the principal component) was taken from projections made by the respective governmental organs that are responsible for these products. For cotton and tobacco, it was not possible to use income elasticities in making projections. The domestic demand was calculated as a residual after extrapolating trends in domestic production and exports.

As can be seen in the table, the largest increases in demand are for plant protein products of non-traditional forms, such as peanuts and soybeans, and some animal products. The latter group includes beef, milk, eggs, and fish. Other products with relatively large increases in demand forecast are coconut oil, bananas and oranges, and Irish potatoes. Relatively small increases in demand are forecast for mandioca, mutton, and tobacco.

\section{SUPPLY}

\section{Levels of Production}

Information on area, yield, total production, exports, imports, and total domestic supply of selected agricultural products in 1960 is presented in Table 124. In Table 125, data are presented on the gross availability of the same selected products for 1960. Gross availability is calculated as total supply minus seeds, eggs for incubation, animal feed, and waste. 
TABLE 123

Projections of Potential Demand, in Terms of Primary Product Equivalent, 1960-1975 (thousand metric tons)

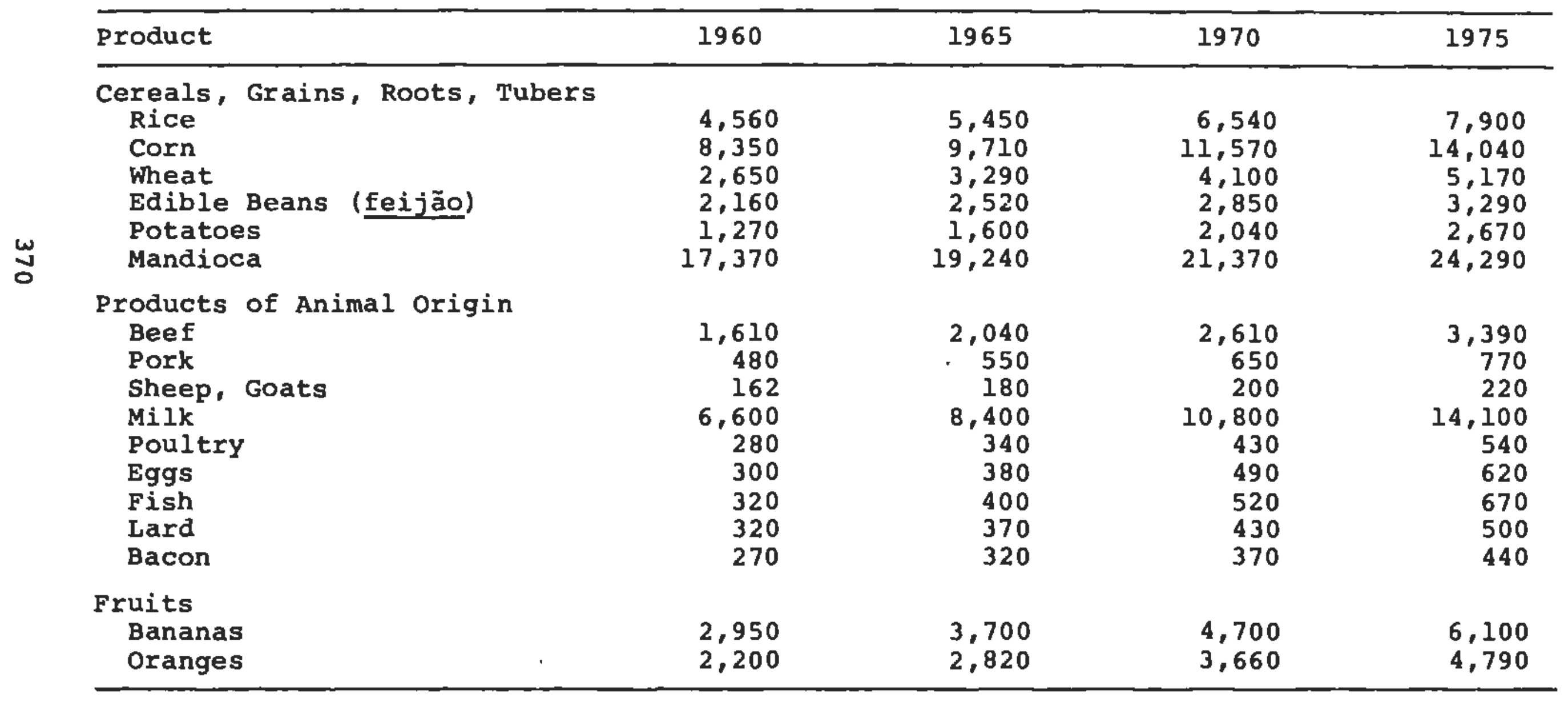




\begin{tabular}{|c|c|c|c|c|}
\hline Product & 1960 & 1965 & 1970 & 1975 \\
\hline $\begin{array}{l}\text { Fats, Vegetable oils } \\
\text { Cotton } \\
\text { Peanuts } \\
\text { olive } \\
\text { Soybeans } \\
\text { Coconut }\end{array}$ & $\begin{array}{r}525 \\
155 \\
9 \\
90 \\
80\end{array}$ & $\begin{array}{r}600 \\
210 \\
10 \\
180 \\
110\end{array}$ & $\begin{array}{r}740 \\
300 \\
12 \\
240 \\
140\end{array}$ & $\begin{array}{r}890 \\
400 \\
14 \\
390 \\
190\end{array}$ \\
\hline $\begin{array}{l}\text { Other } \\
\text { Sugar } \\
\text { Cotton } \\
\text { Tobacco }\end{array}$ & $\begin{array}{r}2,570 \\
1,440 \\
125\end{array}$ & $\begin{array}{r}3,190 \\
1,820 \\
170\end{array}$ & $\begin{array}{r}4,000 \\
2,240 \\
190\end{array}$ & $\begin{array}{r}5,090 \\
2,660 \\
220\end{array}$ \\
\hline
\end{tabular}

Source: Projections of Supply and Demand. 
TABLE 124

Supply of Selected Agricultural Products, 1960

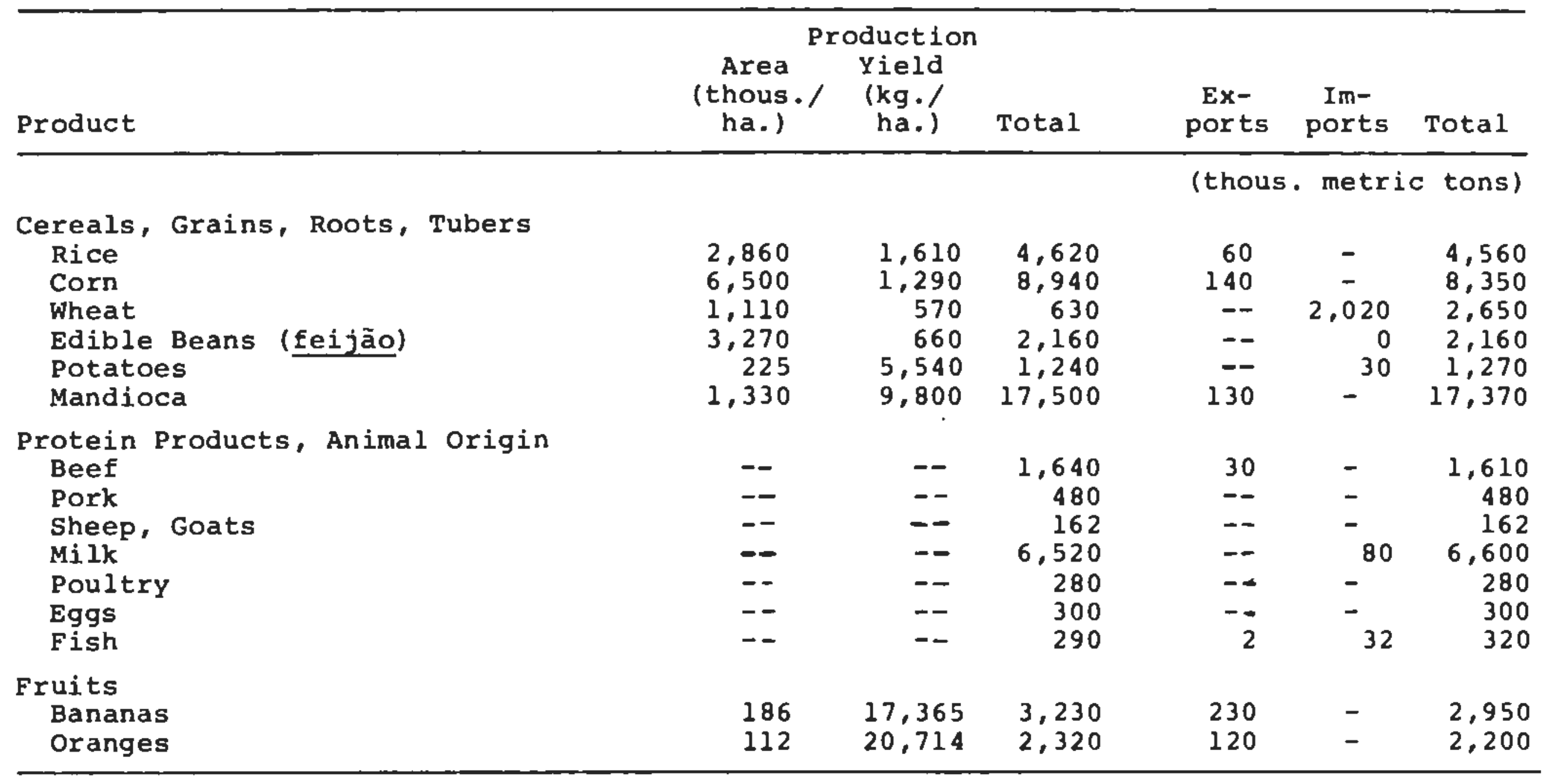




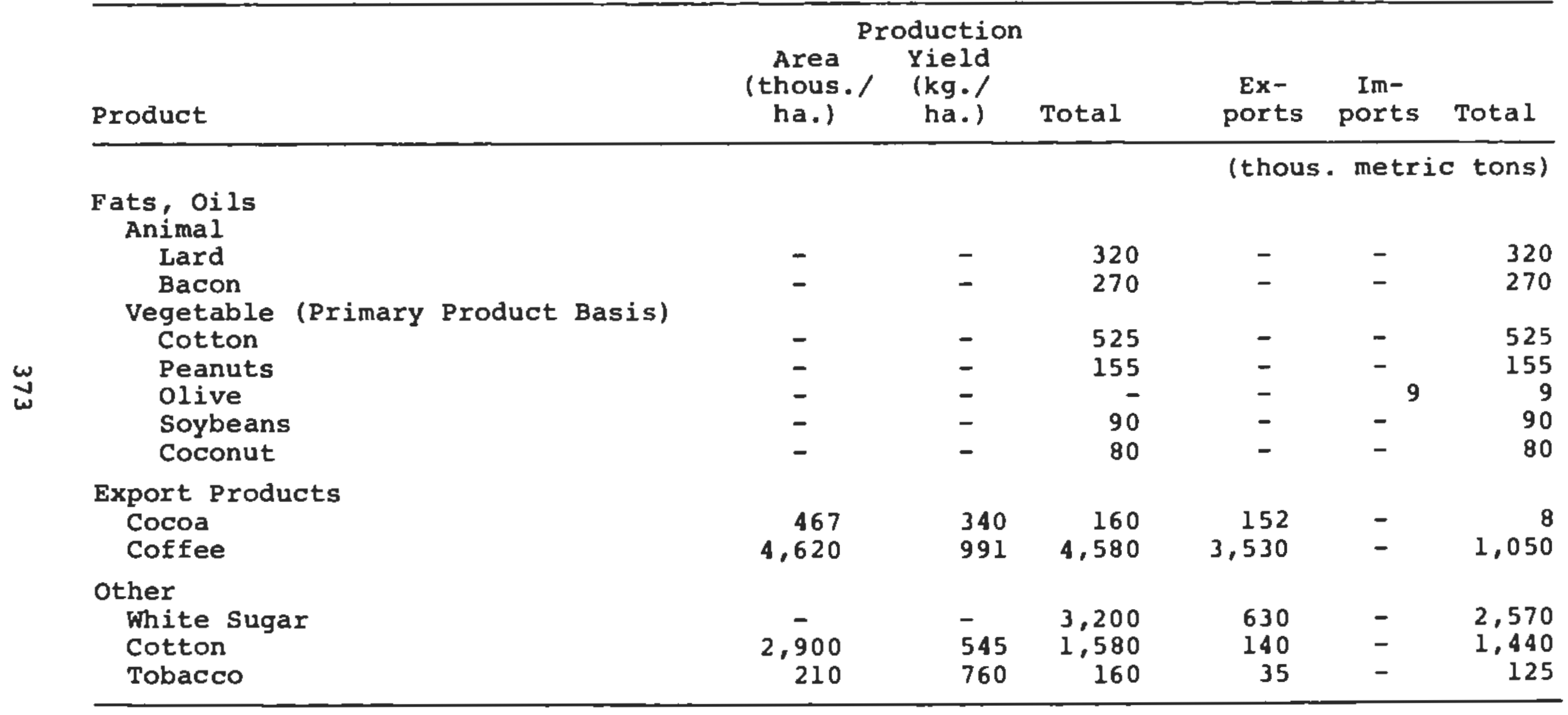

Source: Projections of Supply and Demand. 
TABLE 125

Gross Availability of Selected Agricultural Products, 1960 (thousand metric tons)

\begin{tabular}{|c|c|c|c|c|c|}
\hline \multirow[b]{2}{*}{ Product } & \multirow[b]{2}{*}{$\begin{array}{l}\text { Total } \\
\text { Supply }\end{array}$} & \multicolumn{3}{|c|}{ Deductions } & \multirow{2}{*}{$\begin{array}{l}\text { Total } \\
\text { Avail- } \\
\text { ability }\end{array}$} \\
\hline & & $\begin{array}{c}\text { Seeds, } \\
\text { Incubation }\end{array}$ & $\begin{array}{l}\text { Animal } \\
\text { Feed }\end{array}$ & $\begin{array}{l}\text { Waste, } \\
\text { Losses }\end{array}$ & \\
\hline $\begin{array}{l}\text { Cereals, Grains, Roots, Tubers } \\
\text { Rice } \\
\text { Corn } \\
\text { Wheat } \\
\text { Edible Beans (feijão) } \\
\text { Potatoes } \\
\text { Mandioca }\end{array}$ & $\begin{array}{r}4,560 \\
8,350 \\
2,650 \\
2,160 \\
1,270 \\
17,370\end{array}$ & $\begin{array}{r}280 \\
130 \\
80 \\
130 \\
410 \\
-\end{array}$ & $\begin{array}{c}- \\
6,550 \\
- \\
- \\
\overline{-} \\
7,010\end{array}$ & $\begin{array}{r}140 \\
260 \\
20 \\
60 \\
100 \\
1,400\end{array}$ & $\begin{array}{r}4,140 \\
1,410 \\
2,550 \\
1,970 \\
760 \\
8,960\end{array}$ \\
\hline $\begin{array}{l}\text { Protein Products, Animal origin } \\
\text { Beef } \\
\text { Pork } \\
\text { Sheep, Goats } \\
\text { Milk } \\
\text { Poultry } \\
\text { Eggs } \\
\text { Fish }\end{array}$ & $\begin{array}{r}1,610 \\
480 \\
162 \\
6,600 \\
280 \\
300 \\
320\end{array}$ & $\begin{array}{l}- \\
- \\
- \\
- \\
30 \\
-\end{array}$ & $\begin{array}{l}- \\
- \\
- \\
- \\
-\end{array}$ & $\begin{array}{l}- \\
- \\
- \\
- \\
-\end{array}$ & $\begin{array}{r}1,610 \\
480 \\
162 \\
6,600 \\
280 \\
270 \\
320\end{array}$ \\
\hline $\begin{array}{l}\text { Fruits } \\
\text { Bananas } \\
\text { Oranges }\end{array}$ & $\begin{array}{l}2,950 \\
2,200\end{array}$ & $\begin{array}{l}- \\
-\end{array}$ & $\begin{array}{l}- \\
-\end{array}$ & $\begin{array}{l}295 \\
220\end{array}$ & $\begin{array}{l}2,655 \\
1,980\end{array}$ \\
\hline
\end{tabular}




\begin{tabular}{|c|c|c|c|c|c|}
\hline Product & $\begin{array}{l}\text { Total } \\
\text { Supply }\end{array}$ & $\begin{array}{l}\text { Sed } \\
\text { Seeds, } \\
\text { Incubation }\end{array}$ & $\begin{array}{l}\text { uctions } \\
\text { Animal } \\
\text { Feed }\end{array}$ & $\begin{array}{l}\text { Waste, } \\
\text { Losses }\end{array}$ & $\begin{array}{l}\text { Total } \\
\text { Avail- } \\
\text { ability }\end{array}$ \\
\hline \multicolumn{6}{|l|}{$\begin{array}{c}\text { Fats, Oils } \\
\text { Animal }\end{array}$} \\
\hline $\begin{array}{l}\text { Lard } \\
\text { Bacon } \\
\text { Vegetable }\end{array}$ & $\begin{array}{l}320 \\
270\end{array}$ & $\overline{-}$ & $\overline{-}$ & $\overline{-}$ & $\begin{array}{l}320 \\
270\end{array}$ \\
\hline $\begin{array}{l}\text { Cotton } \\
\text { Peanuts } \\
\text { Olive } \\
\text { Soybeans } \\
\text { Coconut }\end{array}$ & $\begin{array}{r}525 \\
155 \\
9 \\
90 \\
80\end{array}$ & $\begin{array}{l}\overline{-} \\
\overline{-} \\
-\end{array}$ & $\begin{array}{l}- \\
\overline{-} \\
-\end{array}$ & $\begin{array}{l}- \\
\overline{-} \\
-\end{array}$ & $\begin{array}{r}525 \\
155 \\
9 \\
90 \\
80\end{array}$ \\
\hline $\begin{array}{l}\text { Export Product } \\
\text { Cocoa } \\
\text { Coffee }\end{array}$ & $\begin{array}{r}8 \\
1,050^{8}\end{array}$ & - & - & - & $\begin{array}{r}8 \\
1,050^{8}\end{array}$ \\
\hline $\begin{array}{l}\text { Other } \\
\text { White sugar } \\
\text { Cotton } \\
\text { Tobacco }\end{array}$ & $\begin{array}{r}2,570 \\
1,440 \\
125\end{array}$ & $\begin{array}{l}- \\
-\end{array}$ & $\begin{array}{l}- \\
-\end{array}$ & $\begin{array}{l}- \\
-\end{array}$ & $\begin{array}{r}2,570 \\
1,050 \\
125\end{array}$ \\
\hline
\end{tabular}

Source: Projections of Supply and Demand. 
Estimates of Technical Production Functions

The supply projections were based on technical production functions, estimated from sample data, and projections of input use. In this section we shall discuss briefly the production functions and how they were estimated.

The data were collected from a survey that was made at the same time that the family budget study for rural families was made. Approximately 1,800 establishments were investigated in seven states. These seven states produce roughly 60 percent of the national agricultural product, and the only important agricultural states omitted were Paraná, Goiás, and Mato Grosso.

Separate functions were fitted for important enterprises on a state basis, in addition to aggregate functions for crops, livestock, and total agricultural production. The aggregate functions were estimated by an appropriate aggregation (weighting) of the individual functions.

These functions will not be reproduced here, but certain aspects of them are worth noting. For example, in all three aggregate functions, the most important operating cost was labor. For the crop production functions, inputs such as fertilizers and insecticides have little influence on output. For the livestock sector, vaccines and medicines have little effect on output. In both cases this is due to the very limited use of these factors.

In addition, there is almost a perfect inverse correlation between the use of some inputs. The states that use more fertilizers, insecticides, and vaccines use a smaller proportion of land.

The computed marginal productivities also suggest some important relationships. For example, for crops, a simple doubling of the land in crop production will increase production by 48 percent. A simple doubling of labor, however, will increase production by only 12 percent. This testifies to the low productivity of labor at the margin. 
On the other hand, the limited use of inputs that represent new technology makes their influence on production quite low (at least as measured). Thus, if the use of fertilizer, insecticides, and other "defensives" is doubled, production will increase only 6 percent. And doubling the use of capital inputs such as vehicles, machines, and buildings will increase production by only 13 percent.

Projections of the Supply of Factors of Production

Land

Both the area in agriculture and the number of agricultural establishments has been increasing over time. However, agricultural establishments still occupy a relatively small fraction of the total land area in Brazil, and the availability of land does not in itself constitute a limiting factor to the growth of the agricultural sector. Discounting the lands that are not cultivable $(20$ percent, according to the FAO), it can be seen that according to the census of 1960, only 32.1 percent of the area of the country was in agricultural establishments.

Table 127 shows the reduction in farm size that took place between 1950 and 1960. This probably does not represent so much a breaking up of individual farms as it does the addition of a large number of small farms in the rapidly expanding frontier.

Both Table 127 and Table 128 show that of the land in farms, the fraction in crops is comparatively small. In 1960 only 11 percent was in crops, with 46 percent in pastures. This attests to the low intensity at which land is tilled.

Further analysis of the expansion of land effectively utilized between 1950 and 1960 provides some interesting insights. The area in new establishments grew at a rate of 1.3 percent a year, while the area in crops grew at a rate of 4.5 percent a year, and that in pastures grew at a rate of 1.2 percent a year. This suggests that the 


\section{Farmland as a Percentage of Total Land Area, $1940,1950,1960$}

\begin{tabular}{llll}
\hline Specification & 1940 & 1950 & 1960 \\
\hline Area Outside & & & \\
$\quad$ Establishments & 76.7 & 72.6 & 67.9 \\
Area in Establishments & 23.3 & 27.4 & 32.1 \\
\hline
\end{tabular}

Source: Censo Agricola da 1940 and 1950; Censo Agrícola Preliminar, 1960 .

TABLE 127

Land in Farms, $1940,1950,1960$

\begin{tabular}{lrrr}
\hline \multicolumn{1}{c}{ Specification } & \multicolumn{1}{c}{1940} & \multicolumn{1}{c}{1950} & \multicolumn{1}{c}{1960} \\
\hline Number (thousands) & 1,905 & 2,064 & 3,349 \\
$\begin{array}{l}\text { Area (thousand } \\
\text { hectares) }\end{array}$ & 197,720 & 232,211 & 265,451 \\
Crops & 18,835 & 19,095 & 29,760 \\
Woods, Unutilized & 90,743 & 105,568 & 107,891 \\
$\begin{array}{l}\text { Pastures } \\
\text { Average (hectares/ } \\
\quad \text { establishment) }\end{array}$ & 88,142 & 107,548 & 127,800 \\
\hline
\end{tabular}

Source: Censo Agrícola da 1940 and 1950; Censo Agrícola Preliminar, 1960. 
TABLE 128

Agricultural Land in Crops and

Pastures, 1940, 1950, 1960

(percent of total area)

\begin{tabular}{lrrr}
\hline Specification & 1940 & 1950 & 1960 \\
\hline Crops & 9.5 & 8.2 & 10.9 \\
Pastures & 44.6 & 46.4 & 45.7 \\
\hline
\end{tabular}

Source: Censo Agrícola da 1940 and 1950; Censo
Agrícola Preliminar, 1960 .

growth in area utilized depended more on a more intensive use of land in old establishments than on the incorporation of new lands into farms.

The FGV group thought it difficult for the land in crops to grow at a rate equal to that of the previous decade. They base this on the limits imposed by the lack of roads and the limited possibility of further expansion within existing farms. In addition, they argue that a sizable part of the growth in production of food products can come from land on which coffee trees are being eradicated. This eradication is going on at a substantial rate, and much of the land so released is quite fertile. Hence, they conclude that the limit to the rate of 
growth of land in crops will be between 3.5 and 4.0 percent per year.

With respect to pastures, an increase in the rate of growth is expected, even though it may be impossible to meet the expanding demands for beef and milk products. This growth will probably come about as a result of a rise in the relative price of such meat products. Within the period of these projections, the rate of growth of land in pastures is expected to increase between 2.5 and 3.0 percent per year.

\section{Labor}

The active population (labor force) in agriculture is projected to grow at a rate of 1.6 percent a year. Implicit in this projection is an assumption that the labor force will remain in the same proportion to the total rural population. The basic data are summarized in Table 129 .

One of the assumptions made in projecting income from the growth model was that labor productivity would grow at a rate of between 1.9 and 2.7 percent per year. On the other hand, the equilibrium supply and the production functions suggest the following levels of total supply of agricultural labor to attain the estimated demand:

$\begin{array}{ll}1960 & 100.0 \\ 1965 & 118.7 \\ 1970 & 145.4 \\ 1975 & 182.3\end{array}$

These, combined with the projected rates of labor force growth, suggest the following annual rates of productivity growth:

$$
\begin{array}{ll}
\text { Average, } 1960-1965: & 1.98 \\
\text { Average, } 1965-1970: & 2.58 \\
\text { Average, } 1970-1975: & 3.08 \\
\text { Average, } 1960-1975: & 2.48
\end{array}
$$

These rates are within the assumptions made previously. 
TABLE 129

Projections of the Active

Population in Agriculture. $1960-1975$

\begin{tabular}{lccc} 
Year & $\begin{array}{c}\text { Rural Population } \\
\text { (thousands) }\end{array}$ & $\begin{array}{c}\text { Active Population } \\
\text { in Agriculture } \\
\text { (thousands) }\end{array}$ & $\begin{array}{c}\text { Population Active } \\
\text { in Agriculture } \\
\text { as Percent of Rural } \\
\text { Population }\end{array}$ \\
\hline $\mathbf{P}$ & 37,648 & 15,344 & 40.8 \\
1960 & 40,703 & 16,230 & 40.0 \\
1970 & 44,123 & 17,170 & 39.0 \\
1975 & 47,966 & 19,183 & 40.0 \\
\hline
\end{tabular}

Source: Projections of Supply and Demand. 


\section{Capital}

Available information on the value of capital employed in agriculture refers only to the years 1940 and 1950 , since the data for 1960 were not available at the time the study was made. The only information for 1960, and this was preliminary, referred to the number of plows and tractors.

TABLE 130

Number of Tractors and Plows, $1940,1950,1960$

\begin{tabular}{lrrr}
\hline Specification & \multicolumn{1}{c}{1940} & \multicolumn{1}{c}{1950} & \multicolumn{1}{c}{1960} \\
\hline Tractors & 3,380 & 8,372 & 63,493 \\
Plows & 500,853 & 704,259 & $1,031,930$ \\
\hline
\end{tabular}

Source: Censo Agrícola da 1940 and 1950 ; Censo Agrícola Preliminar, 1960.

The number of plows grew 47 percent between 1950 and 1960, and the number of tractors grew 658 percent--on a very small base. But this information is not adequate to define the trends in the growth of fixed capital, especially in view of the small ratio between this and the number of farms, the area planted, and the labor force. (See Chapter 4.)

Because of this, and the fact that the machinery variable was not significant in the estimated production functions, it was decided to group buildings, machinery, equipment, vehicles, and work animals into one variable. Then, through the production functions, the rate at which the capital stock would have to grow in order to supply the effective demand was calculated by iteration. Intermediate demands were accounted for, and the estimates were made product by product, and then added together. 
The results are summarized in Table 131. They suggest that physical capital will have to be accumulated at a rate of 5.3 percent a year in order to meet the effective demand over the projection period.

\section{TABLE $131^{\circ}$}

Rates of Growth of Fixed Capital Necessary to Attain Estimated Demand, 1960-1975

\begin{tabular}{lc}
\hline Period & $\begin{array}{c}\text { Rate of Annual Growth of Fixed } \\
\text { Capital (excluding land) }\end{array}$ \\
\hline $1960-1965$ & 4.3 \\
$1965-1970$ & 6.2 \\
$1970-1975$ & 5.3 \\
$1960-1975$ & 5.3 \\
\hline
\end{tabular}

Source: Projections of Supply and Demand.

\section{Fertilizers}

Data on the past rates of growth in the use of fertilizer were presented earlier. (See Chapter 7.) It should be remembered that the price of fertilizer in Brazil is high in relation to the price of other inputs and the price of most agricultural products. In addition, the market has had a great deal of intervention, either directly or indirectly through the manipulation of exchange rates.

Two series of projected fertilizer use are presented in Tables 132 and 133. One series was presented in a report to the Ministry of Planning. The FGV study took the average of these two as the expected rate of growth in fertilizer use. The results are summarized in Table 134. 
Ministry of Planning Projection of

Fertilizer Consumption,

$1965-1975$

(in tons)

\begin{tabular}{lccr}
\hline Year & Nitrogen & Phosphorus & Potassium \\
\hline 1965 & 81,258 & 159,118 & 96,883 \\
1970 & 122,026 & 194,250 & 123,584 \\
1975 & 171,575 & 229,382 & 150,286 \\
\hline
\end{tabular}

Source: Projections of Supply and Demand.

\author{
TABLE 133 \\ Ministry of Agriculture-USAID \\ Projection of Fertilizer \\ Consumption, 1965-1975 \\ (in tons)
}

\begin{tabular}{lrcr}
\hline Year & Nitrogen & Phosphorus & Potassiun \\
\hline 1965 & 78,000 & 159,000 & 115,000 \\
1970 & 91,000 & 191,000 & 124,000 \\
1975 & 110,000 & 225,000 & 148,000 \\
\hline
\end{tabular}

Source: Projections of Supply and Demand.

TABLE 134

Projected Rates of Increase

in Fertilizer Use,

1960-1975

\begin{tabular}{lc}
\hline Period & Rate of Increase \\
\hline $1960-1965$ & $2.5-3.0$ \\
$1965-1970$ & $3.0-6.0$ \\
$1970-1975$ & $3.5-4.5$ \\
$1960-1975$ & $3.0-4.5$ \\
\hline
\end{tabular}

Source: Projections of Supply and Demand. 
TABLE 135

Projections of Factor Supplies, Annual

Rates of Growth, 1960-1975

(percent)

\begin{tabular}{|c|c|c|c|c|c|c|}
\hline \multirow{2}{*}{$\frac{\text { Period }}{1960-1965}$} & \multicolumn{2}{|c|}{$\begin{array}{l}\text { Land } \\
\text { Moderate Optimistic } \\
\text { Assumption }\end{array}$} & \multicolumn{2}{|c|}{$\begin{array}{l}\text { Fertilizer } \\
\text { Moderate Optimistic } \\
\text { Assumption }\end{array}$} & \multirow{2}{*}{$\begin{array}{l}\begin{array}{l}\text { Labor } \\
\text { Force }\end{array} \\
3.5\end{array}$} & \multirow{2}{*}{$\frac{\begin{array}{c}\text { Fixed } \\
\text { Capital }\end{array}}{4.3}$} \\
\hline & 2.5 & 3.5 & 2.5 & 3.0 & & \\
\hline $1965-1970$ & $2 \cdot 5$ & 3.5 & 3.0 & 6.0 & 4.1 & 6.2 \\
\hline $1970-1975$ & 2.5 & 3.5 & 3.5 & 4.5 & 4.6 & $5 \cdot 3$ \\
\hline $1960-1975$ & 2.5 & 3.5 & 3.0 & 4.5 & 4.1 & 5.3 \\
\hline
\end{tabular}

Source: Projections of Supply and Demand. 


\section{Projections of Potential Supply}

The results from the analysis of the availability of inputs are summarized in Table 135, which presents the projected annual rates of growth in each. The absence of more complete information on land, and the existence of two projections for fertilizer consumption, led to the computation of two separate projections, one representing a more optimistic set of assumptions and the other a moderate set of assumptions.

The introduction of these rates of input growth into the aggregate production function for total Brazilian agriculture produces the rates of growth in output summarized in Table 136. (The supply projections for individual commodities, on the other hand, were based on regressions of per capita production of each commodity with time and real per capita disposable income.)

\section{BALANCE BETWEEN DEMAND AND SUPPLY}

\section{Coefficients of consumption}

In making the projections, it was desired not only to account for changes in consumption that result from rural-urban migration, but also for substitution effects on the demand side that arise from changes in relative prices. Such shifts in relative prices come about because supply does not always respond immediately to changes in demand. In order to measure these "brakes" coming from the supply side, coefficients of consumption were estimated from time series data.

The coefficients were abtained by regressing apparent consumption on real income per capita. The resulting coefficient is the sum of the potential income elasticity and the elasticity of substitution that results from the variations in relative prices. The measure of the substitution produced by the relative prices is then given by the difference between the potential income elasticity (the long-run elasticities abovel and the coefficient of consumption. 
TABLE 136

Annual Rates of Growth of Potential

Supply of Agricultural Products,

1960-1975

(percent)

\begin{tabular}{lcc}
\hline Period & $\begin{array}{c}\text { Moderate } \\
\text { Assumption }\end{array}$ & $\begin{array}{c}\text { Optimistic } \\
\text { Assumption }\end{array}$ \\
\hline $1960-1965$ & 3.0 & 3.6 \\
$1965-1970$ & 3.9 & 4.5 \\
$1970-1975$ & 3.8 & 4.4 \\
$1960-1975$ & 3.6 & 4.2 \\
\hline
\end{tabular}

Source: Projections of Supply and Demand.

\section{Projections of Effective Demand}

The projections of potential demand presented earlier represent the variations in demand expected as a result of changes in income and population. Effective demand, on the other hand, will account for the substitution effects that result from changes in relative prices and supply rlgidity. Thus, it takes account of the secular influences of income and population, but also relates the expected demand to an equilibrium supply. The projections of effective demand are given in $\mathrm{Table} 137$.

\section{Projections of Effective Production}

The projection of effective production was calculated on the basis of a concept of equillbrium supply: domestic demand plus export demand minus import demand equals domestic production. The calculation was made product by product, and then aggregated at 1962 prices. The results are presented in Table 138. 
TABLE 137

Projections of Effective Demand, 1960-1975

(thousand metric tons)

\begin{tabular}{|c|c|c|c|}
\hline Product & 1965 & 1970 & 1975 \\
\hline $\begin{array}{l}\text { Cereals, Grains, Roots, Tubers } \\
\text { Rice } \\
\text { Corn } \\
\text { Wheat } \\
\text { Edible Beans (feijäo) } \\
\text { Potatoon } \\
\text { Mandioca }\end{array}$ & $\begin{array}{r}5,880 \\
10,420 \\
3,080 \\
2,520 \\
1,490 \\
20,870\end{array}$ & $\begin{array}{r}8,330 \\
14,050 \\
3,600 \\
2,850 \\
1,720 \\
26,170\end{array}$ & $\begin{array}{r}11,320 \\
18,670 \\
4,190 \\
3,290 \\
2,010 \\
33,070\end{array}$ \\
\hline $\begin{array}{l}\text { Products of Anlmal origin } \\
\text { Boef } \\
\text { Pork } \\
\text { Sheep, coats } \\
\text { Milk } \\
\text { Poultry } \\
\text { Egge } \\
\text { Fish } \\
\text { Lard } \\
\text { Bacon }\end{array}$ & $\begin{array}{r}1,860 \\
580 \\
170 \\
7,680 \\
340 \\
450 \\
460 \\
310 \\
340\end{array}$ & $\begin{array}{r}2,000 \\
760 \\
180 \\
8,950 \\
430 \\
700 \\
730 \\
220 \\
490\end{array}$ & $\begin{array}{r}2,100 \\
990 \\
180 \\
10,440 \\
340 \\
970 \\
1,000 \\
120 \\
660\end{array}$ \\
\hline $\begin{array}{l}\text { Frulta } \\
\text { Bananas } \\
\text { Oranges }\end{array}$ & $\begin{array}{l}3,760 \\
2,750\end{array}$ & $\begin{array}{l}5,210 \\
3,300\end{array}$ & $\begin{array}{l}7,020 \\
4,000\end{array}$ \\
\hline
\end{tabular}




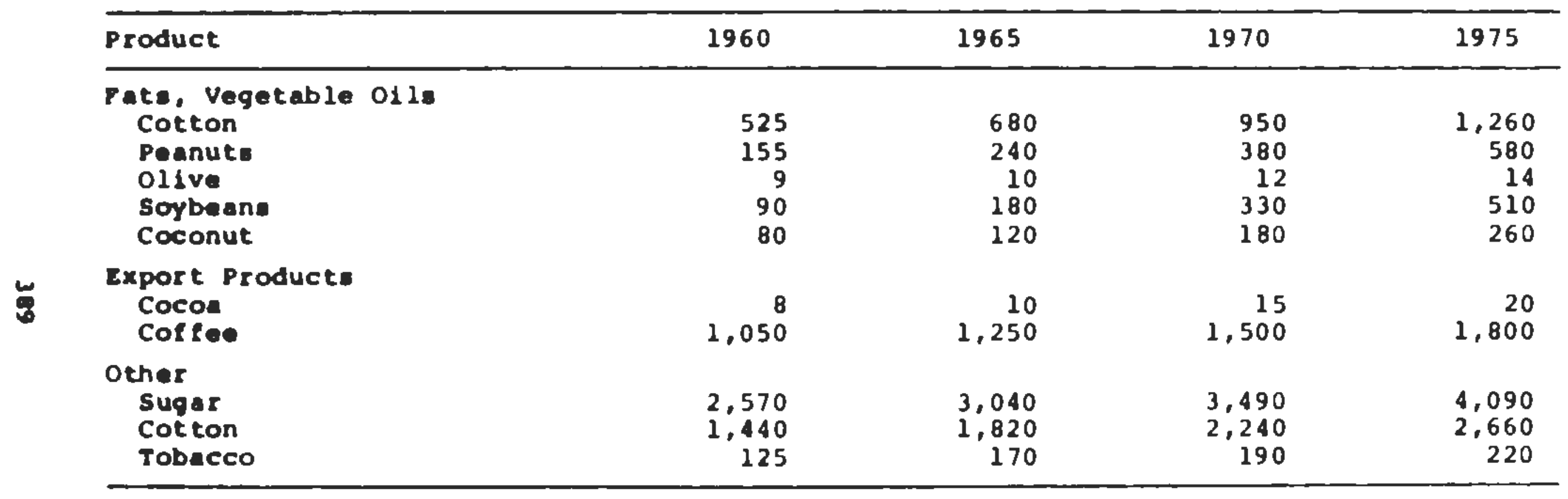

Source: Profectione of Supply and Demand. 


\section{Projections of Value Aggregate Effective Production, $1960-1975$ \\ (in million NCr\$)}

\begin{tabular}{lccc}
\hline Year & Crops & $\begin{array}{c}\text { Animal } \\
\text { Production }\end{array}$ & Total \\
\hline 1960 & 1,015 & 699 & 1,714 \\
1965 & 1,186 & 813 & 1,999 \\
1970 & 1,492 & 961 & 2,453 \\
1975 & 1,879 & 1,126 & 3,005 \\
\hline
\end{tabular}

Source: Projections of Supply and Demand.

TABLE 139

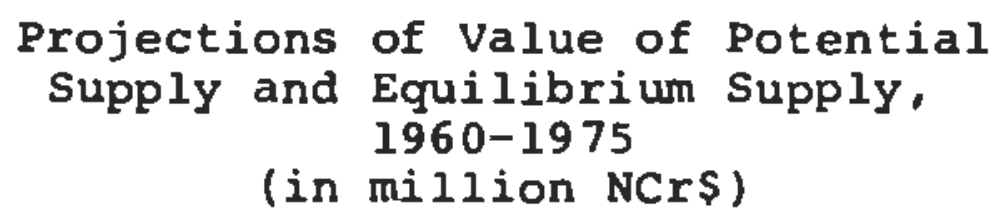

\begin{tabular}{lccc}
\hline Year & $\begin{array}{c}\text { Potential Supply } \\
\text { Lower Limit }\end{array}$ & $\begin{array}{c}\text { Equilibrium Supply } \\
\text { (effective } \\
\text { production) }\end{array}$ \\
\hline 1960 & 1,714 & 1,714 & 1,714 \\
1965 & 1,988 & 2,045 & 1,999 \\
1970 & 2,340 & 2,547 & 2,453 \\
1975 & 2,897 & 3,157 & 3,005 \\
\hline
\end{tabular}

Source: Projections of Supply and Demand. 
The results indicate that within the limits of variations considered for the near future, the realization of equilibrium is possible. The values are within the limits of production fixed by the potential supply.

Data relative to individual products are given in Table 140.

\section{Balance}

The projections of domestic supply and effective demand are presented in Table 141. Supply for domestic consumption is confronted with the effective demand, and the total needs for imports arise naturally as a residual.

In Table 142, the aggregative equilibrium between the demand and supply of agricultural products is presented. Tables $143-146$ present the actual and projected balances between demand and supply for the five-year intervals from 1960 to 1975. The data for 1960 provide the initial conditions from which the projections were made, and are based on fiveyear averages in order to eliminate cyclical effects.

These tables contain two concepts of surplus or deficit. The two concepts arise because of the two concepts of demand used in the analysis: a potential demand and an effective demand.

Potential demand reflects two simplifying assumptions: the level of prices is maintained constant at their 1960 values, and no substitutions as a result of changes in relative prices are accounted for. The concept of effective demand attempts to account for such substitutions.

Domestic supply, of course, represents the response of the agricultural sector to the stimulus of domestic demand, plus the net effect of the demand for exports.

\section{Import Necessities}

Potential deficits for 1965, 1970, and 1975 are shown in Table 147. Although there are sizable potential deficits for several products, the FGV staff 
TABLE 140

Projections of Effective Production, 1960-1975

(thousand tons)

\begin{tabular}{|c|c|c|c|c|}
\hline Product & 1960 & 1965 & 1970 & 1975 \\
\hline $\begin{array}{l}\text { Cereals, Grains, Roots, Tubers } \\
\text { Rice } \\
\text { Corn } \\
\text { Wheat } \\
\text { Edible Beans (feijão) } \\
\text { Potatoes } \\
\text { Handioca }\end{array}$ & $\begin{array}{r}4,600 \\
8,490 \\
630 \\
2,160 \\
1,240 \\
17,500\end{array}$ & $\begin{array}{r}5,930 \\
10,590 \\
760 \\
2,520 \\
1,440 \\
21,030\end{array}$ & $\begin{array}{r}8,400 \\
14,280 \\
840 \\
2,850 \\
1,680 \\
26,240\end{array}$ & $\begin{array}{r}11,420 \\
18,990 \\
980 \\
3,290 \\
1,950 \\
33,780\end{array}$ \\
\hline
\end{tabular}




\begin{tabular}{|c|c|c|c|c|}
\hline Product & 1960 & 1965 & 1970 & 1975 \\
\hline \multicolumn{5}{|l|}{ Fats, Vegetable Oils } \\
\hline $\begin{array}{l}\text { Cotton } \\
\text { Peanuts }\end{array}$ & $\begin{array}{l}525 \\
155\end{array}$ & $\begin{array}{l}680 \\
240\end{array}$ & $\begin{array}{l}950 \\
380\end{array}$ & $\begin{array}{r}1,260 \\
580\end{array}$ \\
\hline olive & - & - & - & - \\
\hline $\begin{array}{l}\text { Soybeans } \\
\text { Coconut }\end{array}$ & $\begin{array}{l}90 \\
80\end{array}$ & $\begin{array}{l}180 \\
120\end{array}$ & $\begin{array}{l}330 \\
180\end{array}$ & $\begin{array}{l}510 \\
260\end{array}$ \\
\hline \multicolumn{5}{|l|}{ Export Products } \\
\hline $\begin{array}{l}\text { Cocoa } \\
\text { Coffee }\end{array}$ & $\begin{array}{r}160 \\
4,580\end{array}$ & $\begin{array}{r}110 \\
3.900\end{array}$ & $\begin{array}{r}180 \\
4.050\end{array}$ & $\begin{array}{r}220 \\
4,200\end{array}$ \\
\hline \multicolumn{5}{|l|}{ other } \\
\hline $\begin{array}{l}\text { Sugar } \\
\text { Cotton } \\
\text { Tobacco }\end{array}$ & $\begin{array}{r}3,200 \\
1,580 \\
160\end{array}$ & $\begin{array}{r}3,800 \\
2,120 \\
220\end{array}$ & $\begin{array}{r}4,340 \\
2,930 \\
290\end{array}$ & $\begin{array}{r}5,090 \\
3,960 \\
380\end{array}$ \\
\hline
\end{tabular}

Source: Projections of Supply and Demand. 
Composition of Domestic Supply and Effective Demand of Agricultural

Products, 1960-1975

(1962 prices, million NCr\$)

\begin{tabular}{lrrrr}
\hline \multicolumn{1}{c}{ Specification } & 1960 & 1965 & 1970 & \multicolumn{1}{c}{1975} \\
\hline Domestic Consumption & 1,526 & 1,837 & 2,255 & 2,758 \\
$\begin{array}{l}\text { Exports } \\
\quad \text { Production }\end{array}$ & 1,714 & 1,999 & 2,453 & 3,005 \\
\hline Production for Domestic & 1,526 & 1,837 & 2,255 & 2,758 \\
$\quad$ Use & 63 & 73 & 88 & 102 \\
$\begin{array}{l}\text { Imports } \\
\text { Effective Domestic } \\
\text { Demand }\end{array}$ & 1,589 & 1,910 & 2,343 & 2,860 \\
\hline
\end{tabular}

Source: Projections of Supply and Demand.

TABLE 142

Total Demand and Supply of Agricultural Products

$$
\text { 1960-1975 }
$$

(1962 prices, million NCr\$)

\begin{tabular}{lrrrr}
\hline Specification & 1960 & 1965 & 1970 & 1975 \\
\hline Domestic Demand & 1,589 & 1,910 & 2,343 & 2,860 \\
Exports & 188 & 162 & 198 & 247 \\
Total Demand & 1,777 & 2,072 & 2,541 & 3,107 \\
\hline Domestic Supply & 1,714 & 1,999 & 2,453 & 3,005 \\
Imports & 63 & 73 & 88 & 102 \\
$\quad$ Total Supply & 1,777 & 2,072 & 2,541 & 3,107 \\
\hline
\end{tabular}

Source: Projections of Supply and Demand. 
TABLE 143

Initial conditions for Projections of Demand and Supply, Selected Agricultural Products, 1960

(thousand tons)

\begin{tabular}{|c|c|c|c|c|}
\hline Product & $\begin{array}{c}\text { Total } \\
\text { Consumption }\end{array}$ & Imports & Exports & $\begin{array}{c}\text { Domestic } \\
\text { Supply }\end{array}$ \\
\hline $\begin{array}{l}\text { Cereals, Grains, Roots, Tubers } \\
\text { Rice } \\
\text { Corn } \\
\text { Wheat } \\
\text { Edible Beans (feijão) } \\
\text { Potatoes } \\
\text { Mandioca }\end{array}$ & $\begin{array}{r}4,560 \\
8,350 \\
2,650 \\
2,160 \\
1,270 \\
17,370\end{array}$ & $\begin{array}{c}\overline{-} \\
2, \overline{020} \\
- \\
{ }^{30}\end{array}$ & $\begin{array}{l}40 \\
140 \\
- \\
- \\
- \\
130\end{array}$ & $\begin{array}{r}4,620 \\
8,490 \\
630 \\
2,160 \\
1,240 \\
17,500\end{array}$ \\
\hline $\begin{array}{l}\text { Products of Animal origin } \\
\text { Beef } \\
\text { Pork } \\
\text { Sheep, Goats } \\
\text { Milk } \\
\text { Poultry } \\
\text { Eggs } \\
\text { Fish }\end{array}$ & $\begin{array}{r}1,610 \\
480 \\
162 \\
6,600 \\
280 \\
300 \\
320\end{array}$ & $\begin{array}{l}- \\
- \\
- \\
- \\
- \\
32\end{array}$ & $\begin{array}{l}-30 \\
- \\
- \\
- \\
\end{array}$ & $\begin{array}{r}1,640 \\
480 \\
162 \\
6,520 \\
280 \\
300 \\
290\end{array}$ \\
\hline $\begin{array}{l}\text { Fruits } \\
\text { Bananas } \\
\text { Oranges }\end{array}$ & $\begin{array}{l}2,950 \\
2,200\end{array}$ & $\begin{array}{l}- \\
-\end{array}$ & $\begin{array}{l}230 \\
120\end{array}$ & $\begin{array}{l}3,230 \\
2,320\end{array}$ \\
\hline
\end{tabular}


TABLE 143 (Continued)

\begin{tabular}{|c|c|c|c|c|}
\hline Product & $\begin{array}{c}\text { Total } \\
\text { Consumption }\end{array}$ & Imports & Exports & $\begin{array}{c}\text { Domestic } \\
\text { Supply }\end{array}$ \\
\hline \multicolumn{5}{|c|}{ Fats, Vegetable oils } \\
\hline Bacon & 270 & - & - & $\begin{array}{l}320 \\
270\end{array}$ \\
\hline cotton & 525 & - & - & 525 \\
\hline Peanuts & 155 & - & - & 155 \\
\hline Corn & 5 & - & - & 5 \\
\hline Olive & 9 & \multicolumn{2}{|l|}{9} & - \\
\hline Soybeans & 90 & \multirow{2}{*}{-} & \multirow{2}{*}{$\overline{-}$} & 90 \\
\hline Coconut & 80 & & & 80 \\
\hline \multicolumn{5}{|c|}{ Export Products } \\
\hline Cocoa & 8 & - & 152 & 160 \\
\hline Coffee & 1,050 & - & 3,530 & 4,580 \\
\hline \multicolumn{5}{|l|}{ other } \\
\hline Sugar & 2,570 & - & 630 & 3,200 \\
\hline cotton & 1,440 & - & 140 & 1,580 \\
\hline Tobacco & 125 & - & 35 & 160 \\
\hline
\end{tabular}

Source: Projections of Supply and Demand. 
Projections of Supply and Demand, Selected Agricultural Products, 1965 (thousand tons)

\begin{tabular}{|c|c|c|c|c|c|}
\hline Product & $\begin{array}{l}\text { Poten- } \\
\text { tial } \\
\text { Demand }\end{array}$ & $\begin{array}{l}\text { Effec- } \\
\text { tive } \\
\text { Demand }\end{array}$ & $\begin{array}{c}\text { Domestic } \\
\text { Supply }\end{array}$ & $\begin{array}{l}\text { Potential } \\
\text { Surplus (+) } \\
\text { or } \\
\text { Deficit (-) }\end{array}$ & $\begin{array}{l}\text { Effective } \\
\text { Surplus (+) } \\
\text { or } \\
\text { Deficit (-) }\end{array}$ \\
\hline $\begin{array}{l}\text { Cereals, Grains, Roots, Tubers } \\
\text { Rice } \\
\text { Corn } \\
\text { Wheat } \\
\text { Edible Beans (feijão) } \\
\text { Potatoes } \\
\text { Mandioca }\end{array}$ & $\begin{array}{r}5,450 \\
9,710 \\
3,290 \\
2,520 \\
1,600 \\
19,240\end{array}$ & $\begin{array}{r}5,880 \\
10,420 \\
3,080 \\
2,520 \\
1,490 \\
20,870\end{array}$ & $\begin{array}{r}5,960 \\
10,590 \\
760 \\
2,520 \\
1,440 \\
21,030\end{array}$ & $\begin{array}{l}+\quad 510 \\
+\quad 880 \\
-2,530 \\
-\quad 160 \\
+1,790\end{array}$ & $\begin{array}{lr}+ & 80 \\
+ & 170 \\
-2,320 \\
\\
-\quad 50 \\
+\quad 160\end{array}$ \\
\hline $\begin{array}{l}\text { Products of Animal Origin } \\
\text { Beef } \\
\text { Pork } \\
\text { Sheep, Goats } \\
\text { Milk } \\
\text { Poultry } \\
\text { Eggs } \\
\text { Fish }\end{array}$ & $\begin{array}{r}2,040 \\
550 \\
180 \\
8,400 \\
340 \\
380 \\
400\end{array}$ & $\begin{array}{r}1,860 \\
580 \\
170 \\
7,680 \\
340 \\
450 \\
460\end{array}$ & $\begin{array}{r}1,860 \\
580 \\
170 \\
7,590 \\
340 \\
450 \\
420\end{array}$ & $\begin{array}{rr}- & 180 \\
+ & 30 \\
- & 10 \\
-\quad 810 \\
& 0 \\
+ & 70 \\
+ & 20\end{array}$ & $\begin{array}{r}0 \\
0 \\
0 \\
90 \\
0 \\
0 \\
40\end{array}$ \\
\hline $\begin{array}{l}\text { Fruits } \\
\text { Bananas } \\
\text { Oranges }\end{array}$ & $\begin{array}{l}3,700 \\
2,820\end{array}$ & $\begin{array}{l}3,760 \\
2,740\end{array}$ & $\begin{array}{l}4,110 \\
2,740\end{array}$ & $\begin{array}{l}+\quad 410 \\
-\quad 80\end{array}$ & $\begin{array}{r}350 \\
0\end{array}$ \\
\hline
\end{tabular}


TABLE 144 (Continued)

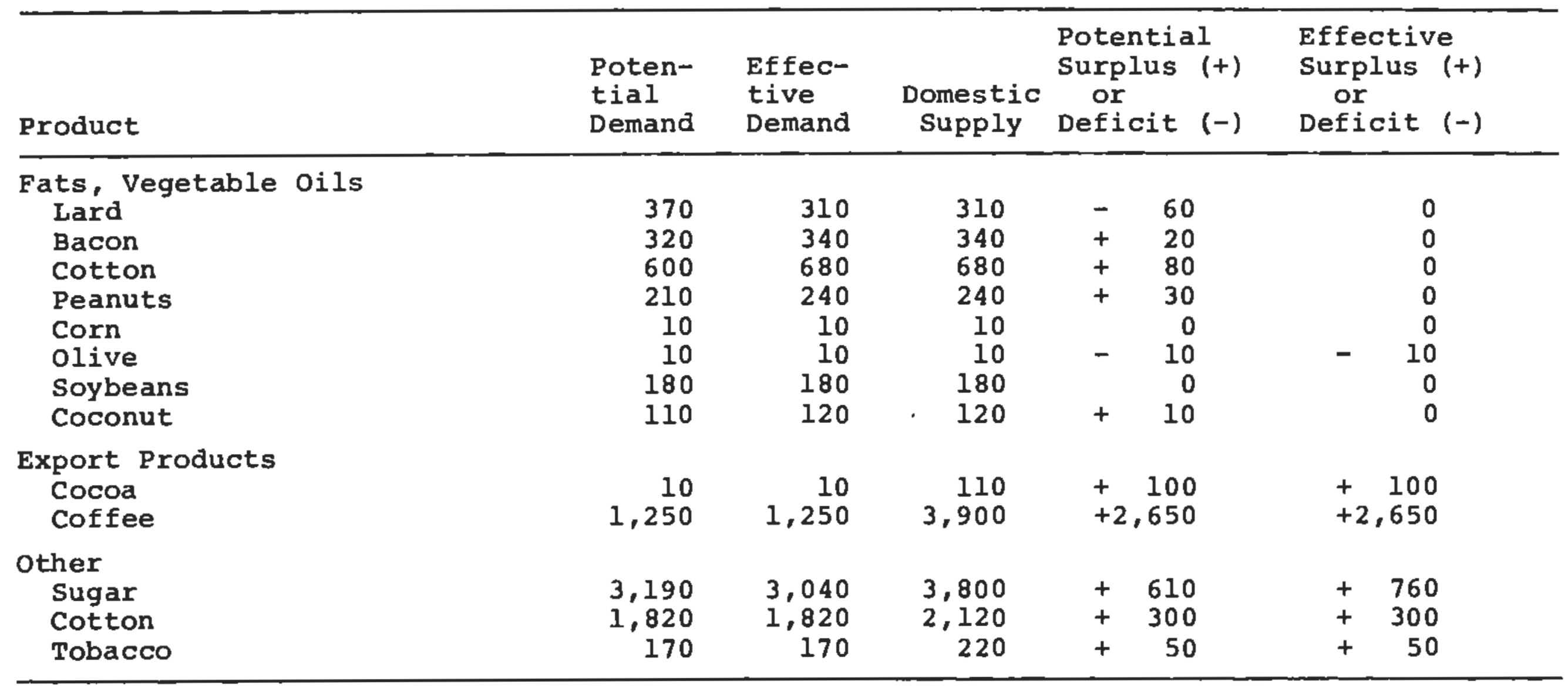

Source: Projections of Supply and Demand. 
Projection of Demand and Supply, Selected Agricultural Products, 1970 (thousand tons)

\begin{tabular}{|c|c|c|c|c|c|}
\hline Product & $\begin{array}{l}\text { Poten- } \\
\text { tial } \\
\text { Demand }\end{array}$ & $\begin{array}{l}\text { Effec- } \\
\text { tive } \\
\text { Demand }\end{array}$ & $\begin{array}{c}\text { Domestic } \\
\text { Supply }\end{array}$ & $\begin{array}{l}\text { Potential } \\
\text { Surplus (+) } \\
\text { or } \\
\text { Deficit (-) }\end{array}$ & $\begin{array}{l}\text { Effective } \\
\text { Surplus (+) } \\
\text { or } \\
\text { Deficit (-) }\end{array}$ \\
\hline $\begin{array}{l}\text { Cereals, Grains, Roots, Tubers } \\
\text { Rice } \\
\text { Corn } \\
\text { Wheat } \\
\text { Edible Beans (feijão) } \\
\text { Potatoes } \\
\text { Mandioca }\end{array}$ & $\begin{array}{r}6,540 \\
11,570 \\
4,100 \\
2,850 \\
2,040 \\
21,370\end{array}$ & $\begin{array}{r}8,330 \\
14,050 \\
3,600 \\
2,850 \\
1,720 \\
26,170\end{array}$ & $\begin{array}{r}8,440 \\
14,280 \\
840 \\
2,850 \\
1,680 \\
26,240\end{array}$ & $\begin{array}{r}+1,900 \\
+2,710 \\
-3,260 \\
-\quad 360 \\
+4,870\end{array}$ & $\begin{array}{lr}+ & 110 \\
+ & 230 \\
-2,760 \\
-\quad 0 \\
+\quad 40 \\
+\quad 70\end{array}$ \\
\hline $\begin{array}{l}\text { Products of Animal Origin } \\
\text { Beef } \\
\text { Pork } \\
\text { Sheep, Goats } \\
\text { Milk } \\
\text { Poultry } \\
\text { Eggs } \\
\text { Fish }\end{array}$ & $\begin{array}{r}2,610 \\
650 \\
200 \\
10,800 \\
430 \\
490 \\
520\end{array}$ & $\begin{array}{r}2,000 \\
760 \\
180 \\
8,950 \\
430 \\
700 \\
730\end{array}$ & $\begin{array}{r}2,000 \\
760 \\
180 \\
8,840 \\
430 \\
700 \\
660\end{array}$ & $\begin{array}{l}-\quad 610 \\
+\quad 110 \\
-\quad 20 \\
-1,850 \\
+\quad 210 \\
+\quad 140\end{array}$ & $\begin{array}{r}0 \\
0 \\
0 \\
-\quad 110 \\
0 \\
0 \\
-\quad 70\end{array}$ \\
\hline $\begin{array}{l}\text { Fruits } \\
\text { Bananas } \\
\text { Oranges }\end{array}$ & $\begin{array}{l}4,700 \\
3,660\end{array}$ & $\begin{array}{l}5,210 \\
3,290\end{array}$ & $\begin{array}{l}5,700 \\
3,290\end{array}$ & $\begin{array}{l}+1,000 \\
-\quad 370\end{array}$ & $\begin{array}{r}490 \\
0\end{array}$ \\
\hline
\end{tabular}


TABLE 145 (Continued)

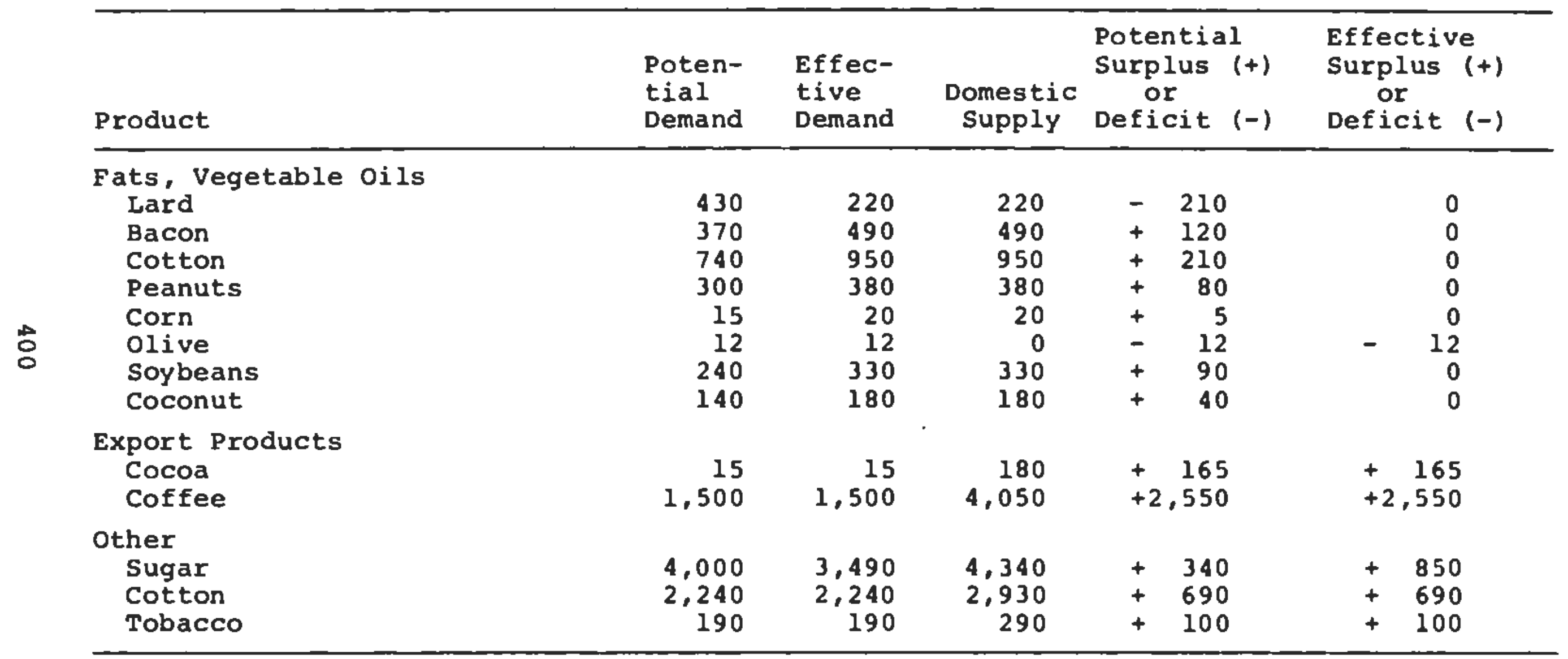

Source: Projections of Supply and Demand. 
Projection of Demand and Supply, Selected Agricultural Products, 1975 (thousand tons)

\begin{tabular}{|c|c|c|c|c|c|}
\hline Product & $\begin{array}{l}\text { Poten- } \\
\text { tial } \\
\text { Demand }\end{array}$ & $\begin{array}{l}\text { Effec- } \\
\text { tive } \\
\text { Demand }\end{array}$ & $\begin{array}{c}\text { Domestic } \\
\text { Supply }\end{array}$ & $\begin{array}{l}\text { Potential } \\
\text { Surplus (+) } \\
\text { or } \\
\text { Deficit (-) }\end{array}$ & $\begin{array}{l}\text { Effective } \\
\text { Surplus (+) } \\
\text { or } \\
\text { Deficit (-) }\end{array}$ \\
\hline $\begin{array}{l}\text { Cereals, Grains, Roots, Tubers } \\
\text { Rice } \\
\text { Corn } \\
\text { Wheat } \\
\text { Edible Beans (feijão) } \\
\text { Potatoes } \\
\text { Mandioca }\end{array}$ & $\begin{array}{r}7,900 \\
14,040 \\
5,170 \\
3,290 \\
2,670 \\
24,290\end{array}$ & $\begin{array}{r}11,320 \\
18,670 \\
4,190 \\
3,290 \\
2,010 \\
33,070\end{array}$ & $\begin{array}{r}11,470 \\
18,990 \\
980 \\
3,290 \\
1,950 \\
33,780\end{array}$ & $\begin{array}{r}+3,570 \\
+4,950 \\
-4,190 \\
0 \\
+\quad 720 \\
+9,490\end{array}$ & $\begin{array}{rr}+ & 150 \\
+ & 320 \\
-3,210 \\
\\
-\quad 60 \\
+\quad 710\end{array}$ \\
\hline $\begin{array}{l}\text { Products of Animal origin } \\
\text { Beef } \\
\text { Pork } \\
\text { Sheep, Goats } \\
\text { Milk } \\
\text { Poultry } \\
\text { Eggs } \\
\text { Fish }\end{array}$ & $\begin{array}{r}3,390 \\
770 \\
220 \\
14,100 \\
540 \\
620 \\
670\end{array}$ & $\begin{array}{r}2,100 \\
990 \\
180 \\
10,440 \\
540 \\
970 \\
1,000\end{array}$ & $\begin{array}{r}2,100 \\
990 \\
180 \\
10,310 \\
540 \\
970 \\
910\end{array}$ & $\begin{array}{r}-1,290 \\
+\quad 220 \\
-\quad 40 \\
-3,790 \\
+\quad 350 \\
+\quad 240\end{array}$ & $\begin{array}{r}0 \\
0 \\
0 \\
-\quad 130 \\
0 \\
0 \\
-\quad 90\end{array}$ \\
\hline $\begin{array}{l}\text { Fruits } \\
\text { Bananas } \\
\text { Oranges }\end{array}$ & $\begin{array}{l}6,100 \\
4,790\end{array}$ & $\begin{array}{l}7,020 \\
3,990\end{array}$ & $\begin{array}{l}7,690 \\
3,990\end{array}$ & $\begin{array}{l}+1,590 \\
-\quad 800\end{array}$ & $\begin{array}{r}670 \\
+\quad 0\end{array}$ \\
\hline
\end{tabular}


TABLE 146 (Continued)

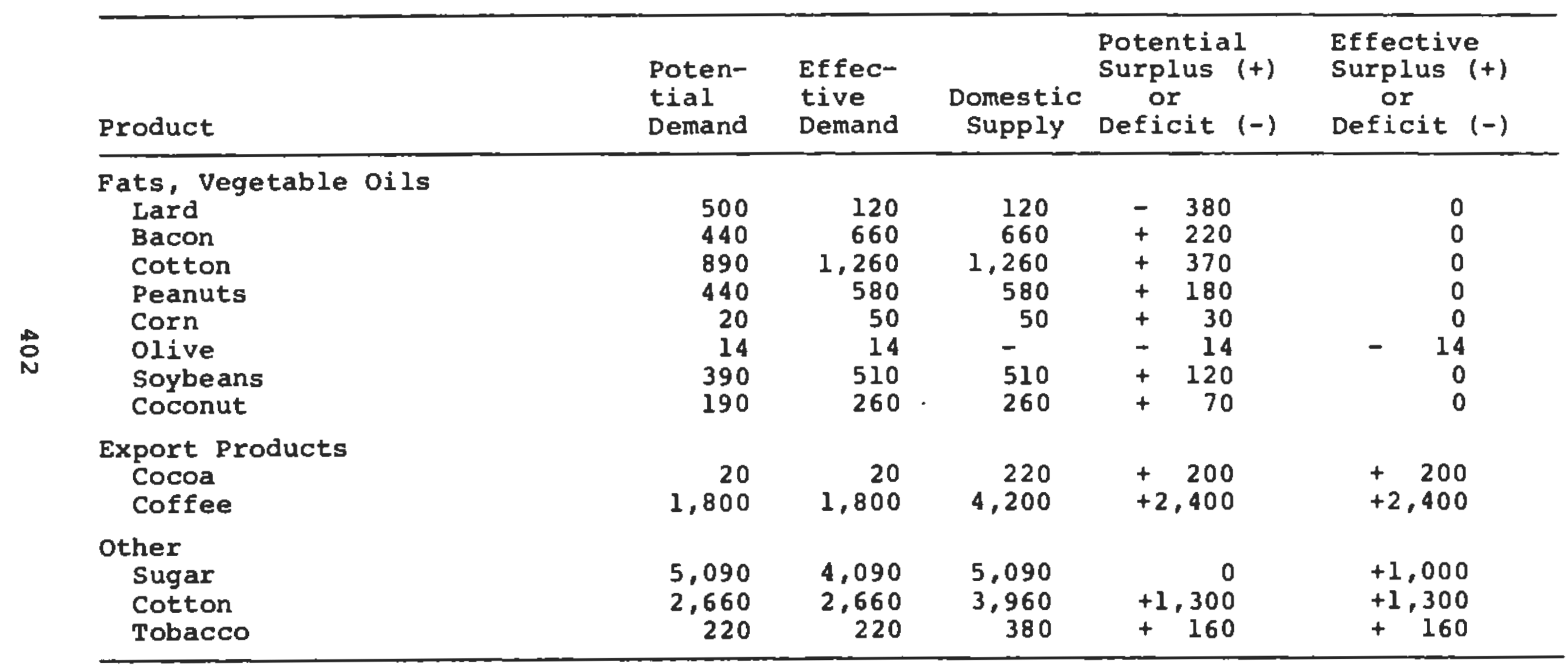

Source: Projections of Supply and Demand. 
TABLE 147

Projections of Potential Deficits of Agricultural Products, 1965, 1970,1975 (thousand tons)

\begin{tabular}{|c|c|c|c|}
\hline Product & 1965 & 1970 & 1975 \\
\hline $\begin{array}{l}\text { Cereals, Grains, Roots, Tubers } \\
\text { Wheat } \\
\text { Potatoes }\end{array}$ & $\begin{array}{r}2,530 \\
160\end{array}$ & $\begin{array}{r}3,260 \\
360\end{array}$ & $\begin{array}{r}4,190 \\
720\end{array}$ \\
\hline $\begin{array}{l}\text { Protein Products, Animal Origin } \\
\text { Beef } \\
\text { Mutton, Goats } \\
\text { Milk } \\
\text { Codfish }\end{array}$ & $\begin{array}{r}180 \\
10 \\
310 \\
40\end{array}$ & $\begin{array}{r}610 \\
20 \\
1,850 \\
70\end{array}$ & $\begin{array}{r}1,290 \\
40 \\
3,790 \\
90\end{array}$ \\
\hline $\begin{array}{l}\text { Fruits } \\
\text { Oranges }\end{array}$ & 80 & 370 & 800 \\
\hline $\begin{array}{l}\text { Fats, Oils } \\
\text { Lard } \\
\text { Olive oil }\end{array}$ & $\begin{array}{l}60 \\
10\end{array}$ & $\begin{array}{r}210 \\
12\end{array}$ & $\begin{array}{r}380 \\
14\end{array}$ \\
\hline
\end{tabular}

\section{Source: Projections of Supply and Demand.}


did not expect, given the restrictions of foreign trade policies, that sufficient quantities would be imported to meet all of these demand requirements.

They argued that it was likely that only three categories of food imports would be permitted:

1. Products not produced in the country: codfish and olive oil.

2. Products with only a minimal production in relation to demand: wheat and potatoes.

3. Products received as donations from other countrieg or international organizations: milk and milk products.

Even restricting imports to these products, it is doubtful whether demands will be met because of trade restrictions. Table 148 indicates what the FGV staff expects the imports of these products to be if current trade policies are maintained. The shortfall can be seen by comparing the two tables.

Exportable Surpluses

Table 149 shows the potential surpluses of agricultural products in 1965, 1970, and 1975, calculated as the positive residual between the potential demand and the domestic supply. These surpluses are those that would arise if potential demand could be attained from domestic supply or imports and assuming the same relative prices of 1960.

Data on effective surpluses for export are presented in Table 150. These estimates reflect substitutions which take place on the demand side due to changes in relative prices and supply bottlenecks. Implicitly these corrections accounted for restrictions imposed by foreign trade policy.

To better understand these substitutions, comments will be made on a group-by-group basis.

Cereals, Grains, Tubers, Roots. In this group the largest deficits are in wheat and potatoes. Even with the imports indicated in Table 148, the potential deficit for wheat, for example, remains sizable. The projection for the import of potatoes foresees only the import of seed potatoes. 
TABLE 148

Projections of Effective Imports, Agricultural Products, 1965, 1970, 1975 (thousand metric tons)

\begin{tabular}{|c|c|c|c|}
\hline Product & 1965 & 1970 & 1975 \\
\hline $\begin{array}{l}\text { Cereals, Grains, Roots, Tubers } \\
\text { Wheat } \\
\text { Potatoes }\end{array}$ & $\begin{array}{r}2,320 \\
50\end{array}$ & $\begin{array}{r}2,760 \\
40\end{array}$ & $\begin{array}{r}3,210 \\
60\end{array}$ \\
\hline $\begin{array}{l}\text { Protein Products, Animal origin } \\
\text { Milk } \\
\text { Fish }\end{array}$ & $\begin{array}{l}90 \\
40\end{array}$ & $\begin{array}{r}110 \\
70\end{array}$ & $\begin{array}{r}130 \\
90\end{array}$ \\
\hline $\begin{array}{l}\text { Fats, Oils } \\
\text { olive Oil }\end{array}$ & 10 & 12 & 14 \\
\hline
\end{tabular}

Source: Projections of Supply and Demand. 
TABLE 149

Projections of Potential Surpluses, Agricultural Products, 1965, 1970, 1975 (thousand metric tons)

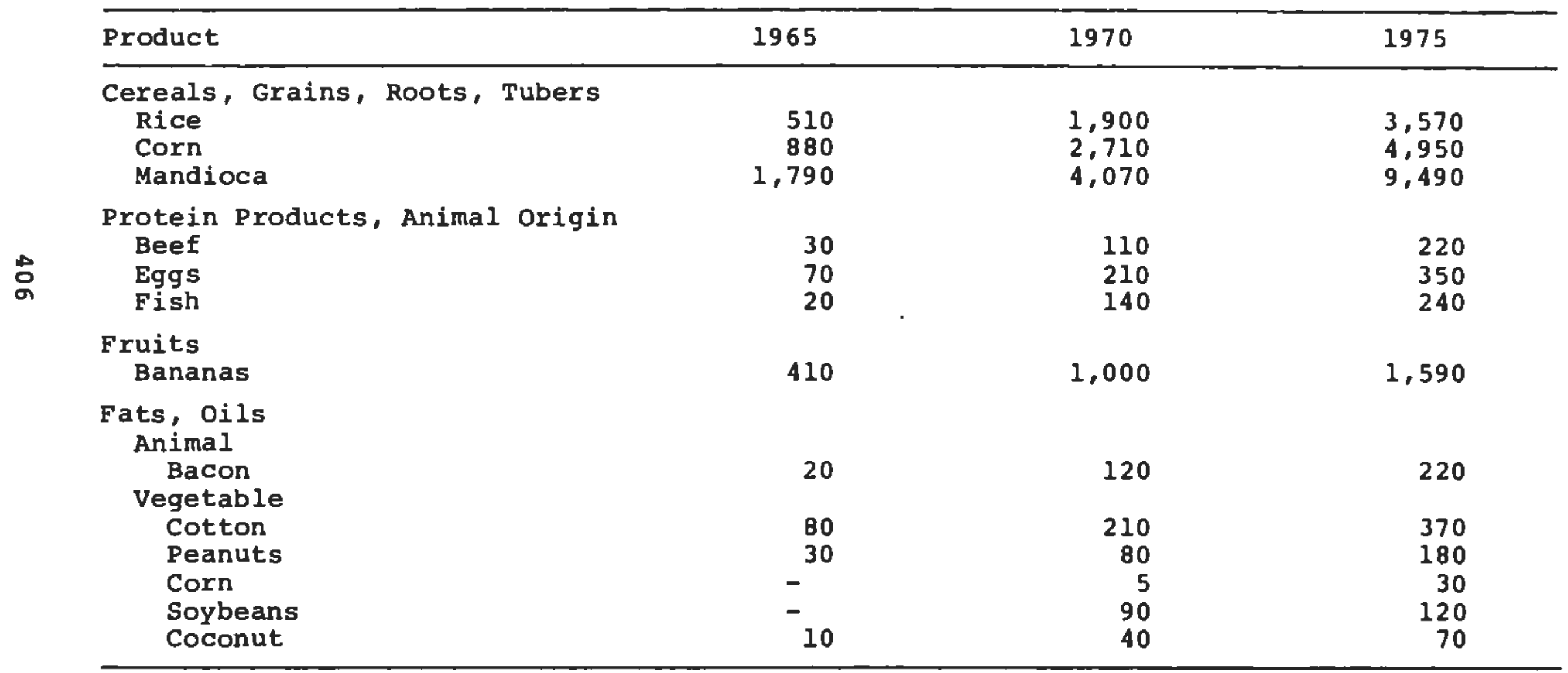




\begin{tabular}{|c|c|c|c|}
\hline Product & 1965 & 1970 & 1975 \\
\hline \multicolumn{4}{|l|}{ Export Products } \\
\hline $\begin{array}{l}\text { Cocoa } \\
\text { Coffee }\end{array}$ & $\begin{array}{r}100 \\
2,650\end{array}$ & $\begin{array}{r}165 \\
2,550\end{array}$ & $\begin{array}{r}200 \\
2,400\end{array}$ \\
\hline \multicolumn{4}{|l|}{ other } \\
\hline $\begin{array}{l}\text { White sugar } \\
\text { Cotton } \\
\text { Tobacco }\end{array}$ & $\begin{array}{r}610 \\
300 \\
50\end{array}$ & $\begin{array}{l}340 \\
690 \\
100\end{array}$ & $\begin{array}{r}\overline{3}, \\
160\end{array}$ \\
\hline
\end{tabular}

Source: Projections of Supply and Demand. 
TABLE 150

Projections of Effective Exports, Agricultural Products, 1965, 1970, 1975 (thousand metric tons)

\begin{tabular}{|c|c|c|c|}
\hline Product & 1965 & 1970 & 1975 \\
\hline $\begin{array}{l}\text { Cereals, Grains, Roots, Tubers } \\
\text { Rice } \\
\text { Corn } \\
\text { Mandioca }\end{array}$ & $\begin{array}{r}80 \\
170 \\
160\end{array}$ & $\begin{array}{r}110 \\
230 \\
70\end{array}$ & $\begin{array}{l}150 \\
320 \\
710\end{array}$ \\
\hline $\begin{array}{l}\text { Fruits } \\
\text { Bananas } \\
\text { Oranges }\end{array}$ & $\begin{array}{l}350 \\
100\end{array}$ & $\begin{array}{l}490 \\
125\end{array}$ & $\begin{array}{l}670 \\
150\end{array}$ \\
\hline $\begin{array}{l}\text { Export Products } \\
\text { Cocoa } \\
\text { Coffee }\end{array}$ & $\begin{array}{r}100 \\
2,650\end{array}$ & $\begin{array}{r}165 \\
2,550\end{array}$ & $\begin{array}{r}200 \\
2,400\end{array}$ \\
\hline $\begin{array}{l}\text { Other } \\
\text { White sugar } \\
\text { Cotton } \\
\text { Tobacco }\end{array}$ & $\begin{array}{r}760 \\
300 \\
50\end{array}$ & $\begin{array}{l}850 \\
690 \\
100\end{array}$ & $\begin{array}{r}1,000 \\
1,300 \\
150\end{array}$ \\
\hline
\end{tabular}

Source: Projections of Supply and Demand. 
The potential deficit for these two products is expected to be in part compensated for by the substitution of other products in this general category. This explains why the potential exports of rice, corn, and mandioca are reduced substantially in estimating effective exports in Table 150. In addition, the exports of corn and mandioca were further reduced because it was felt that part of the potential surpluses will go to further expansion of the production of beef and poultry, both of which will have a rising demand if Brazil reassumes its rate of development.

Protein Products. The sizable potential deficit in beef, mutton and goats, and milk is expected to be in part compensated for by modest surpluses in the production of pork and $f i s h$. However, substantial imports of milk and milk products are likely to be necessary, as will the importation of fish. (Milk imports were 80,000 tons in 1960 , measured in freshmilk equivalent.) Despite the large export potential for fish, as indicated in Table 149, Brazil is likely to continue to import fish in the quantities indicated. Two reasons are given for this expectation. First, the potential excess will disappear as fish is substituted for beef, which is expected to be in short supply. In addition, the bulk of the fish imports will be of those types (cod, for example) that are not available in the country.

Fruits. A sizable deficit in oranges is suggested in Table 147. However, this will be neutralized in part by the excess in production of bananas. In both cases, however, a rather large export is foreseen. This is because both products are highly seasonal in nature, with limited possibilities of preservation. This leads to exportable surpluses in the harvest seasons of the year.

Fats, Oils. If hog production should continue to shift to a more meat-type animal, the potential deficit of lard could become great. This deficit will be compensated for in part by the increased supply of bacon and by the increased availability of vegetable oils, which will lead to product substitution. 


\section{CONCLUDING COMMENTS}

Profections of output and demand this far into the future have serious limitations, and depend on a large number of assumptions. However, they can provide useful insights into the future and a basis for developing a more rational policy. What the analysis presented above basically shows is that Brazil can meet its food needs in the near future without a great deal of strain. More land is likely to be brought into production, and labor is likely to flow out of agriculture at a continued high rate. But the basic food demands can be met rather easily.

On the other hand, with appropriate policies, Brazil could provide substantial amounts of food products to meet a rising world demand, and hence create employment opportunities within the agricultural sector. The potential is certainly there. Alternatively, it could expand its production significantly for the domestic markets, thereby lowering relative food prices and in turn improving the relative position of the lower-income classes. In either case, the contribution of the agricultural sector to the total growth of the economy would be expanded considerably.

Problems with individual products are likely to arise in only two cases. One case is wheat, which Brazil will most likely continue to import in relatively large quantities for a considerable period of time. Given comparative advantage conditions, it would probably not be wise to expend large quantities of resources on developing domestic supplies, although efforts to adapt the new wheats being developed at the International Center in Chapingo, Mexico, may enable Brazil to reduce its import needs with a relatively small expenditure.

The problem with animal protein, however, is quite different. Brazil has a large livestock herd, and much of its agricultural land has a comparative advantage in this enterprise. There seems to be little reason why the country would have to depend on imports. Modernization of the livestock sector would enable Brazil to become self-sufficient in both dairy and meat products. However, this will require expenditures on research and education in addition to the implementation of other economic policies. 
NOTES

1. Projections of Supply and Demand for Agricultural Products of Brazil Through 1975 (Rio de Janeíro: IBRE, FGV, 1968), Also available in Portuguese. 


\section{CHAPTER 9 THE POLICY ALTERNATIVES}

In this chapter a set of policy alternatives for strengthening the agricultural sector is proposed. These alternatives reflect not only a diagnosis of the nature of the farm problem in Brazil, but also a judgment of what the policy goals of the society appear to be with respect to the agricultural sector.

As the data presented in the previous chapters have indicated, Brazil is not a food crisis country, nor is it likely to become one in the future. Output of food products in the aggregate could continue to increase at about the same rate as demand will increase without a great deal of stress. This could be done by bringing more land into cultivation, as well as by the expanded use of other conventional resources.

However, the provision of an adequate food supply in the aggregate is not the only aspect of the agricultural sector which must be considered. The analysis has suggested that within the food sector there are likely to be some important imbalances. One of the more important of these is the provision of an adequate supply of protein products, and most especially those coming from the livestock sector.

Other aspects of the agricultural sector are equally important. First, it seems clear that there are serious discrepancies in the levels of income between the farm and non-farm sectors of the economy, reflecting in part the very low level of productivity of resources in the farm sector, and in part a very imperfect labor market.

Second, there are serious regional imbalances within the farm sector." The extremes are represented by the South and the Northeast. In the South the agriculture is prosperous and undergoing a rapid modernization. In the Northeast, rural people have 
very low levels of income, and very little modernization of the agricultural sector is taking place.

Finally, although the agricultural sector has performed passably well in the postwar period, especially in view of its general neglect by the public sector, it is not clear that agriculture has made the contribution to total development that it could have made. This is a reflection of the relatively low level of productivity in the sector, as well as of the pursuit of general economic policies which have prevented it from making the contribution which it could have. This is most notably reflected in the prohibition of exports and the overvaluation of the exchange rate, which prevented agriculture from being a greater source of exchange earnings.

In our judgment, major efforts to strengthen the agricultural sector should be directed towards raising the level of productivity in this sector, and to attempting to alleviate the rather serious income distribution problems so that the fruits of economic progress are shared on a wider base. Efforts should be made to attack at least three aspects of the income distribution problem: (1) the discrepancy between the farm and non-farm sectors; (2) the very sizable regional imbalance in incores; and (3) the very highly skewed personal distribution of income, which, although not documented in the present study, is widely recognized as existing.

Although it seems clear that at this stage in Brazil's development greater effort should be made to strengthen the agricultural sector, this is not to argue for an agriculture-first policy. On the contrary, the development of a modern, prosperous agriculture will depend in large part on the maintenance of a strong, growing non-farm sector of the economy.

It is equally important that policies designed to strengthen the agricultural sector not be developed in isolation from more general economic policies. In many respects the set of general economic policies which is pursued will have as much influence on agriculture, and the people who obtain their employment there, as the set of explicitly agricultural policies. This is especially true of monetary and fiscal policies to control inflation, which are necessary if viable capital markets are to be 
developed; of foreign trade and exchange rate policies, which are important in providing expanding markets for agriculture; and of the set of policies pursued to foster a more rapid rate of industrialization, which is important in providing employment opportunities for the excess labor in agriculture. Inappropriate policies in any one of these three areas can frustrate any direct policy measures which are taken to strengthen agriculture per se.

The desiderata in terms of general economic policy are as follow:

1. Efforts should be made to promote the expansion of the total economy at the highest possible rate consistent with reasonable price stability. This is not to argue the orthodoxy of no inflation. Neither is it to accept the high and variable rates of inflation of the past, which have rather large, deleterious effects on the capital market. Rather, it is to argue that monetary and fiscal policy should be designed to avoid employment of resources due to insufficient aggregate demand, but to do this with the minimum rate of inflation.

2. Development policies per se should be designed to promote the expansion of employment opportunities and the development of a sectoral distribution of production that is consistent with comparative advantage. This means the abandonment of the importsubstitution industrialization policy, and an attempt to obtain capital-labor ratios that reflect the true opportunity costs of the resources.

3. Foreign trade policy should be frankly expansive. An attempt should be made to keep the exchange rate close to its equilibrium level, and the expansion of exports should be taken as an explicit goal.

The pursuit of these general economic policies will be highly complementary to the policies to be suggested below, which are designed primarily to strengthen the agricultural sector per se. They will provide expanding employment opportunities, strengthen the capital markets, and provide for an expanding market for farm products.

The remainder of this chapter is organized in four parts. The first part examines four policy 
alternatives that are frequently proposed as being essential for the strengthening of the agricultural sector in Brazil, but to which we give low priority. The second part discusses policies which we suggest should receive high priority in strengthening the agricultural sector. The third part discusses some complementary policies which can make a major contribution, but which are of secondary importance in comparison with the others. The chapter terminates with some concluding comments.

\section{CONVENTIONAL PROPOSALS}

\section{Land Reform}

Land reform is a common prescription for the ills of Brazilian agriculture, 1 as it is in other countries of Latin America. The usual concept of land reform is to buy up or disappropriate land and redistribute it to the landless, although more sophisticated proposals which involve tax measures are sometimes proposed.

The existence in Brazil of conditions which lead to agitation for land reform is clear. The distribution of land holdings is very skewed, with many landowners holding only a small fraction of the land and a small percentage holding the major portion. Workers are in many cases exploited by a monopsonistic labor market. And wages and incomes in some rural areas are at little more than subsistence levels.

However, the data on the distribution of land holdings must be interpreted with care. Moreover, attention should be given in the analysis to identifying true causal variables, and not mere symptoms of more basic problems. As was shown in an earlier chapter, aggregate data on the distribution of land holdings are quite misleading. Many of the large land holdings are relatively isolated from the mainstream of economic life, and are being held for purely speculative purposes. Even if they were put to productive use, they generally would not have access to the market economy unless heavy expenditures on infrastructure were made. 
More important, data which show a low productivity per hectare for large units and a high productivity per hectare for small units are quite deceptive. (Data such as these are frequently an important basis of the argument for breaking up large holdings.) one cannot conclude from such data that large farms should be broken up into small farms, thereby increasing total productivity and increasing agricultural output.

The large farms may be large of necessity because the soil productivity is low. If this is the case, large units are necessary in order to have economically viable units. Breaking up such units may only result in a large number of low-productivity, inefficient units that are not capable of providing an adequate income to their owners. This will especially be the case if the land is given to poorly trained, poorly equipped laborers who have little or no entrepreneurial skill.

It is important to recognize that low wages among agricultural laborers have causes that are much more fundamental than the distribution of $l$ and among landowners. The low income levels reflect the low rate of investment in people, the low value placed on labor, and the lack of employment alternatives. Of these, only the latter is affected by land redistribution schemes and, in general, in a form that is not always economically sound.

The problem which gives rise to the demand for land reform is basically a labor-market problem, and reflects in large part the low value attached to agricultural labor. Policies which attempt to improve the functioning of the labor market, which valorize labor, and which create employment alternatives will go a long way towards eliminating many of the problems imputed to the "unsatisfactory" distribution of land holdings.

A multi-pronged program which could deal with these problems, and at the same time facilitate a more equitable distribution of land holdings, would be as follows:

1. Elimination of the high rate of inflation, which encourages the purchases of land as a means of protection against currency depreciation. 
2. Establishment of a credit policy and legislation which would facilitate the purchase of land by those able to till it (that is, lending terms that extend over a 20-year period).

3. Continued attempts to strengthen the total economy so that employment opportunities are available and the labor force is no longer subject to monopsonistic labor market conditions.

4. The expansion of educational opportunities and investment in the human agent so that the laborer has marketable skills and is no longer bound by ignorance.

5. The provision of labor market information that will inform the laborer of opportunities available to him and will facilitate the functioning of the labor market in allocating the skills and resources where they can be most effectively utilized.

These proposals would make a positive attack on the problem and would deal with basic causes, not symptoms. Moreover, they would not subject the society or the economy to the stress and strain. associated with forceful disappropriation and redistribution of land.

\section{Increased Colonization}

The expansion of colonization programs and of the land in farms is frequently proposed as a means of alleviating the problems of the rural sector. Three reasons are generally given for this proposal. The first is that it will alleviate the pressure on the land in high-density areas, particularly in the Northeast. The second is that it is important to settle the frontier before somebody else decides to do it--a political factor. And the third is that agriculture must provide more job opportunities for the rapidly growing labor force, since the non-farm sector cannot absorb all of the new entrants.

It is true that colonization can alleviate the population pressures of the Northeast, as well as provide employment opportunities on a more general scale. It may also be in the long-run interest of Brazil to settle the interior. However, it should be recognized that colonization of new areas is a 
heavy user of resources. A complete infrastructure has to be built, including roads, communications, and other public facilities. Such resources might be better used in attempting to raise the productivity of resources where they are, thereby increasing the economic strength of the country, rather than in widely dispersing them over a large area.

Moreover, creating employment opportunities in agriculture at this stage in the development of Brazil may well be a second-best solution. Although certainly better than having large fractions of the labor force unemployed, it is not clear that it would represent the best use of resources. The mark of a developing economy is a situation in which the food and fiber needs of the country can be produced with a declining agricultural labor force, an increasing fraction of the labor force being used to produce those goods associated with a higher standard of living. The resources used in colonization might better be used to make the labor force more employable in other alternatives and to develop those sectors which have a high income elasticity of demand.

\section{Irrigation}

Irrigation is quite frequently proposed as a means of increasing agricultural output and increasing productivity, especially in the dry Northeast. A number of important river basins appear to have considerable potential for irrigation projects, and plans are underway to carry out a number of these projects. Moreover, irrigation has been an important source of increased output in some countries.

However, it would not seem wise to develop capital-intensive irrigation projects on an extensive scale in Brazil, even with the potential that some river basins seem to have. Most of the country has a satisfactory level of rainfall; and even in areas where it is short, it appears that the use of fertilizer and other management practices can produce output increases with a lower resource cost.

This does not mean, of course, that irrigation for the production of high-value crops should not be considered where it is economically viable, nor 
that cost-benefit ratios on some irrigation projects might not be such as to make them rational investments. However, irrigation projects are costly, and they are not likely to contribute much to solving the general problem of low productivity in the agricultural sector unless massive investments are made.

\section{The Marketing System}

As discussed earlier, deficiencies in the marketing system are quite frequently identified as the major factors inhibiting agricultural progress. Emphasis is given to the role of the middleman, who presumably exploits both the consumer and the producer, and to deficiencies in the transportation and storage infrastructure. Policy prescriptions usually include the strengthening of the transportation system, public investments in warehouses and silos, and the extension of credit to farmers in order that they not be at the complete mercy of the middleman.

We do not discount the importance of having an efficient marketing system. An improved marketing system can benefit both the consumer and the producer. However, we don't consider deficiencies in the marketing system for agricultural products to be a major factor affecting agricultural development, nor do we think that policy measures directed to strengthening the market system will contribute in a major way to the modernization of agriculture or to raising the relative incomes of rural people. We do think the measures designed to strengthen this sector are complementary to the major policy needs, and discuss them at that point in the chapter.

SOME HIGH-PRIORITY POLICIES FOR STRENGTHENING THE AGRICULTURAL SECTOR

The policies which should be given high priority are those directed to raising the productivity of resources used in the agricultural sector. Basically, such policies involve investments in the human agent and in the production of new knowledge. Related policies involve development of the industries which supply the new modern inputs and the strengthening of the labor market. 


\section{Strengthening Agricultural Research}

A key factor in the modernization of Brazilian agriculture and the elevation of the productivity of resources used in this sector will be the strengthening of agricultural research. Although the beginning of a research system is in place, the present capacity of the system is quite low in relation to the needs of the country.

Many would argue that investing in research is not necessary in a country that has such an abundant supply of land. However, this ignores two very important points. 2 The first is that the return to investments in research is quite high. For every dollar invested through 1956 in the development of hybrid corn in the United states, it has been shown that the social rate of return to society was 700 percent. 3 This is a phenomenal rate of return, and there are few alternative investments that could match it.4 A country cannot afford not to make such investments.

The second point that tends to be ignored, or at least not well understood, is the role that productivity change plays in economic growth. Recent research has shown that per capita growth in income in rapidly developing countries has little to do with the stock of physical capital, but is explained largely by increases in the stock of knowledge and education.5 These are the factors which account for the change in productivity, which is what ultimately leads to rising per capita incomes.

It could be argued that research to develop new technology does not have to be done in Brazil, since it can be imported at a very low price from more advanced countries. This argument ignores the ecological specificity of the major fraction of agricultural research. It is true that many of the principles and basic insights can be transferred from one region to another. But, in the final analysis, adaptive research is required under conditions that are unique to specific ecological areas.

A more important problem in Brazil is the general lack of knowledge about tropical agriculture and about the soils found in Brazil. This suggests the need for basic research. 
The recently developed international centers for agricultural research can make a significant contribution to the strengthening of agricultural research around the world. (Information on the international centers can be found in the annual reports of the Ford Foundation and the Rockefeller Foundation.) In a very real sense they lower the real cost of making a given technological change within a given country. However, the potential benefits from the international centers will not in general be realized until an adequate capacity for agricultural research is developed in the individual countries. The new knowledge developed in these centers will in most cases have to be adapted to local conditions.

The important need in Brazil is to develop a limited number of critically located research centers throughout the country. With the scarce resources that are available for such purposes, care should be taken not to proliferate a large number of small, ineffective research centers. Rather, an effort should be made to concentrate funds for research purposes in the development of a limited number of high-quality centers.

From a regional standpoint, the greatest need at the present time would appear to be to strengthen the research system in the Northeast. Population density is high in that region, income levels are quite low, dependence on agriculture is high, and the research infrastructure is quite limited. High priority should be given to developing at least one very strong research center in this region, and to the application of science and technology to the solution of problems in the region.

Viewed from a national standpoint, the priority needs are an upgrading in the level of training of the research staffs and a larger, more dependable funding base. As was indicated earlier, much of the agricultural research in Brazil is conducted by researchers with little more than B.S.-level training. If a productive research effort is to be developed, this level of training will have to be raised substantial1y.

Once an adequately trained staff is developed, the financial support for agricultural research will have to be greatly increased. Not only should this 
support be increased, it should be established on a more stable base. Research administrators have for some time been plagued with budget cuts that come partway through the fiscal year and seriously prejudice on-going research programs. This is a very inefficient way of economizing resources.

Beyond the efforts to upgrade the research staff and to provide expanded financial support for research, efforts should be made to direct the research effort along priority lines of work. The present wide diversification of research effort should be replaced by one which attempts to concentrate the effort on a limited number of high-priority needs. At the present time, it would appear that a substantial effort should be made to strengthen the research on the livestock sector and on the production of plant proteins. Protein deficiencies are already a rather serious nutritional problem, especially among the low-income classes. In addition, the production of meat products is not keeping up with increasing demand, despite the very large livestock herd which Brazil has. The recent success in introducing high-protein genes into cereals and other plants should be adopted in Brazil at an early date.

Next in importance will be work on other food products. Although the production of many of these crops is expanding about in accord with demand, considerable room exists for increasing the efficiency with which they are produced.

Beyond these, efforts should be directed towards the strengthening of the competitive position of products sold in the world market and those which provide a base for industrialization. Given the rich endowment of agricultural resources which Brazil has, the agricultural sector can continue to be an important source of exhange earnings. It will need to be efficient, however, in order to compete. If an attempt is made to develop the food grain sector, the benefits not only will redound domestically, in the form of lower food prices, but also will enable Brazil to contribute importantly to the alleviation of the world food problem. 
Increased Investment in Rural People

Brazil is still investing in her rural people at a relatively low rate. The formal educational attainment of the rural population is substantially below that of the urban sector, and the urban sector itself does not come off with high marks. Extension-type activities have begun, but reach only a small fraction of the total farm population. Vocational training is only minimal.

The consequences of this low rate of investment in people are pervasive. Little innovative activity takes place among large fractions of the rural population, and little attempt is made to adopt new ways of doing things. Hence, much of the agricultural sector remains tradition-bound.

Migrants leaving the rural areas for the cities arrive with few salable skills. Finding employment is difficult, and they ultimately congregate in favelas, where they become a source of social unrest and create political pressure. At the same time, the industrial sector is hamstrung for lack of people with usable skills. The lineage of advertising in são Paulo newspapers for skilled labor, at the same time that unemployment rates are high, is a measure of this problem.

Finally, there is a general lack of the highly skilled manpower that is necessary for developing a modern agriculture. Only a very small fraction of the population receive university-level training, and a relatively small fraction of these are in agronomic sciences. The number that go on for graduate work is still smaller.

This situation will have to be corrected if Brazil is to attain a self-sustaining rate of economic growth. The essence of progress is knowledge, and the utilization of knowledge requires a highly trained labor force. The high rate of social return on investments in education has been well documented, as has the contribution of education in attaining high rates of growh in other countries. 6 Brazil cannot afford not to make these investments.

A multi-pronged approach will be necessary. A high-priority need is for the extension of lowerlevel education to all rural people. As a minimum, 
the first six years of schooling should be provided to all young people, and illiteracy should be eliminated from the adult rural population to the extent possible. Literacy programs are especially important for those under 40 years of age.

The lack of resources, especially human resources, will preclude the general attainment of secondary education in the near future. But concentrated efforts should be made to expand the opportunities for secondary education as rapidly as possible. A careful assessment of relative rates of return is likely to indicate that important fractions of development resources can justifiably be channeled in this direction.

It is quite important that minimal secondary education opportunities be provided in the rural areas. The provision of such opportunities will enable a larger fraction of the agronomos to come from a farm background, and will help in making both teaching and research programs more effective.

The basic need at the lower end of the educational system is to provide formal schooling, rather than to provide training for specific employments. Formal schooling will make for a more mobile labor force and will create conditions in which the individual can continue to grow and study on his own. This does not mean, however, that vocational training should be neglected. On the contrary, the existing technical or vocational schools can play a major role in raising the skill levels of the agricultural labor force. Their staff will have to be upgraded, however, and curricula will have to be revised in order for them to be truly effective.

It would seem that the agricultural colleges should play a larger leadership role in obtaining strong lower-level schools in rural areas. The agricultural colleges have a responsibility to rural people, and it is to their own best interests to strengthen lower-level schools in order to have wellprepared students. Moreover, work at this lower level will give them a much broader political base and will facilitate their obtaining the financial support which they need.

Extension programs should be expanded and strengthened. As we have argued previously, it is 
important that balance be kept between research and extension--and in a sense neither can be more effective than the other. As the research component is strengthened, it will be important to expand the extension service so that it has an impact on a larger number of farm people.

An important aspect of expanding the amount of higher-level education is creation of employment conditions in which highly skilled technicians can work and in which they are rewarded for the opportunity costs they have forgone in attaining higher education. If highly trained technicians can work effectively, and if they are compensated adequately, they and/or their families will have the incentive to invest in a higher-level education. This may be a more efficient means of stimulating higher-level education than the present system of providing such large direct subsidies for university training. The individual would pay a larger fraction of his educational costs at the university level, but would also be compensated with a higher salary at a later date. The present lack of differentiation in salaries for different training levels is an important factor inhibiting competent people from attaining additional training.

In assessing the payoffs to the educational investment in rural people, it should be remembered that the effects will spread generally throughout the economy. Not only will the lower food prices which will come from an increase in productivity redound in a larger proportion to poor people, thereby effecting an important redistribution of income, but the impact on the labor market per se will be pervasive. Higher educational levels will make for a more mobile labor force, one which either has the skills to obtain non-farm employment directly or can obtain the necessary skills more easily. This should substantially reduce the imperfections in the labor market and facilitate making the most effective use of the labor supply.

Development of Supply Industries for Modern Inputs

It is being increasingly recognized that the essence of technological change is the adoption of new or higher-quality inputs into the production 
process. Examples are the adoption of fertilizer, improved varieties, insecticides, and fungicides. Mechanization is in general a substitution of capital for labor, but brings with it a higher level of technique also.

Some of these new inputs have to be created, and knowledge about how to use others has to be generated. For example, new higher-yield varieties have to be developed to suit the ecological conditions of Brazil. Spray schedules for fungicides and other disease controls have to be developed. And the optimum combination of plant nutrients has to be discovered. This, of course, was the basis of the suggestion to improve the research effort in Brazil.

But as knowledge is accumulated about how to use these new inputs, and as new inputs are generated, a production capacity for producing them within Brazil should be developed, especially in those cases where it is economically viable to do so. Important steps can be taken in this direction, even while research programs are being developed.

Perhaps the most important place to start is with the fertilizer industry. Brazilian soils are known to be deficient in most of the major plant nutrients. Although research on how to utilize these fertilizers, and on the optimum levels to use, is extremely limited, enough is known in a general way so that increased use will come about if the relative price is lowered. And farmers themselves can do some of the innovation and experimentation that is necessary to learn how to use them.

The important point is to make these nutrients available, and to make them available at a price low enough that it will be profitable to use them. The raw material base is apparently adequate for Brazil to become self-sufficient in the production of all except potassium. The development of the fertilizer industry should be stimulated by whatever means is necessary, including the granting of tax credits or the loan of development funds at a low rate. In addition, it is important that economically sized units be established and that high levels of technology be adopted, in order that the price of the fertilizer be low. 
Alternative means of stimulating the use of fertilizer would be to raise the price of agricultural products so that fertilizer use would be profitable, or to lower the price through the use of import subsidies. Neither of these is a desirable solution over the long run. Supporting food prices above equilibrium levels is a tax on consumers and involves a redistribution of income away from the poor. Import subsidies are heavy resource users, and also discourage the development of the domestic industry. It would appear much more rational to lower the price of the input by developing an efficient, modern domestic fertilizer industry based on the most recent technological developments in this industry.

A second supply industry which should be developed immediately is that for machinery, equipment, and tractors. It is true that at present price relatives, mechanization is in general not economically viable. However, the prices of tractors and equipment need not be as high as they are, and $a$ lowering of the price should encourage the substitution of capital for labor.

Mass mechanization can, of course, create serious employment problems. However, if the effort is directed towards the production of machinery and equipment adapted to Brazilian conditions, with the emphasis on small units, the adjustment problem may not be critical in the short run. In any case, it seems clear that a man working only with a hoe is not going to be very productive. If he is not productive, he is not going to have a high income level. The labor adjustment problem will just have to be faced by the appropriate means.

The relatively strong automotive industry in Brazil provides a basis for developing a viable machinery and equipment industry. Some part of the entrepreneurial know-how should be transferable, as well as the skills acquired by the labor force.

other supply industries that can be developed include those which have a chemical base, such as the pesticides. These are almost entirely imported at the present time, and hence are both expensive and a drain on exchange earnings. It would seem 
that many of these products could be produced in Brazil, and they would provide an expanding market for the growing chemical industry.

The final supply industry is the seed industry. Little specialization of seed production has taken place so far in Brazil, with the exception of the production of hybrid seed corn. However, the production of high-quality seeds through well-developed breeding programs requires specialization. This should be encouraged wherever possible, especially as the research capacity for generating improved varieties is developed.

\section{Strengthening of Labor Market Infrastructure}

It appears that the labor market in Brazil is quite imperfect. Although adjustments do take place, they are not sufficient to eliminate inter-sectoral and inter-regional income differences, and there seem to be substantial discontinuities in the market.

One source of imperfection in the labor market, of course, is the serious deficiency in the educational programs. This problem has been considered above. But complementary programs designed to strengthen the infrastructure of the labor market will also be necessary.

In a rapidly growing and changing economy, the correct allocation of labor is an important problem, not only in increasing individual welfare but also in making more efficient use of the resources at hand. Two factors give added importance to this problem in Brazil. The first is the widespread argument that the agricultural labor force is exploited by monopsony purchases of labor. One means of avoiding this is to provide the labor force with marketable skills, create employment opportunities, and make the labor force aware of them.

The second factor will become increasingly important as the agricultural sector is modernized. If productivity is in fact raised in the agricultural sector, the need to transfer labor to the nonfarm sector will be especially great. Policy measures should be implemented to facilitate this transfer so that those remaining in agriculture do not have to bear the full costs of economic progress. 
The labor market will be strengthened substantially if the government establishes an employment service which attempts to collect information on changing employment opportunities and on changing labor market conditions, and which has as its primary objective the matching up of job opportunities and potential employees. (other suggestions for improving the labor market were given in Chapter 2.) This service should have a nation-wide network, with a means of exchanging and distributing information on labor market conditions on an extensive basis. Complementary programs should provide information to the labor force on where they can acquire the skills in short supply. This will require a continuous survey of vocational and training schools, both public and private, where laborers can obtain the necessary skills.

Although the establishment of such a system will be a rather costly undertaking, its contribution to economic growth, as well as to obtaining a wider distribution of the fruits of that growth, can be great. It should enable the labor market to handle its allocatory function more efficiently, and help to reduce both the inter-sectoral and inter-regional income differences that are presently so great.

\section{SOME COMPLEMENTARY POLICIES}

The policies discussed in this section can make a contribution to the modernization of the agricultural sector, although they are not expected to make the contribution of those suggested in the previous section. In many respects they are complementary to those policies, however, and should be considered as important elements of an integrated set of policy measures.

\section{An Improved Credit Policy}

Two important changes should be made in agricultural credit policy. The first is to re-establish the price of credit as a factor in its allocation. Given the present rate of inflation and the low ceilings placed on interest charges, the bulk of the credit coming through the public and institutional banking sector is allocated on grounds other than economic considerations. Most effective use of these 
will not be made until price is given a more important role and until this price reflects more adequately the conditions in the capital market.

The second important change to be made is to expand the amount of intermediate- and longer-term credit available to finance needed improvements in farm organization and to facilitate the transfer of land holdings. This may require innovations in the form of credit instruments, especially in the direction of accounting for changes in the purchasing power of money.

We have not placed high priority on credit policy, despite the fact that it frequently receives high ranking among those concerned with the agricultural sector. There are a number of reasons for this. First, and most important, we feel that the policies suggested in the previous section will have a greater effect. Second, we believe that the control of inflation, if successful, will have a substantial effect on the capital markets and, hence, that considerable improvement will take place as a result of these changes. And finally, we feel that the informal credit market is much larger than is generally recognized, and that aside from the risks associated with this market, it is probably not functioning too badly.

\section{An Improved Transportation and Communication System}

Although not, strictly speaking, an agricultural policy, the agricultural sector can benefit from efforts to strengthen the general transportation and communication system. Such improvements will attack the root causes of what is conventionally identified as the marketing problem.

Brazil is currently making a sizable effort to strengthen its transportation and communication systems. From the standpoint of agriculture, special attention should be given to increasing the facilities and means for handling bulk products. The most important needs are an expanded and modernized railroad system, an improvement in the ports and in port facilities, and a substantial improvement in the maritime fleet and in water transportation generally. 
Some of these will require direct government expenditures, but others can be handled through financial and fiscal incentives and with technical assistance.

\section{A Rational Price Policy}

Brazil has attempted to implement a policy of minimum prices for agriculture. However, this program has not been effective, except possibly in 1965, because the rate of inflation has in general been so great that the prices set have been less than the prices eventually realized in the market.

The increase in resource efficiency that can result from an effective forward price program for agriculture is generally recognized. 7 The certainty with which resources can be combined and production decisions can be made leads to improved resource use.

However, an effective system of forward prices is dependent on a strong knowledge of how the economy functions. It is necessary to know how farmers respond to price, to be able to forecast domestic and export demands, and to be able to forecast other developments in the economy. In general, sufficient knowledge is not now available on the Brazilian economy to effectively implement a policy of forward prices. In this context, it would seem both dangerous and wasteful to institute such a program at the present time. 8

Adequate price incentives are necessary if the agricultural sector is to be modernized, however, and attempts should be made to reduce price instability. Perhaps the best that can be attained in the near future is to avoid measures which discriminate against the agricultural sector, such as the prohibition of exports and the periodic rollbacks of domestic prices. If these can be attained, the private storage sector can act to reduce the wider price fluctuations. Since Brazil is relatively unimportant in the world markets for most feed and food grains, access to this market can provide an additional degree of price stability. 


\section{Expanded Capacity for Economic Research}

Brazil has only a limited capacity for economic research. 9 Some of the same manpower problems prevail in this sector that exist with respect to the agricultural research infrastructure.

The capacity for economic research will have to be expanded substantially if Brazil is to attain a more rational use of her resources and if economic policy is to be more right than wrong. This not only will involve the training of economists to higher levels, but also will require the strengthening of the economic data on which economic decisions are to be based and the development of institutions free of political influence, in which economists can work effectively.

The greatest need is for research with a direct policy orientation. Although almost all economic research has policy implications, some can be designed to bear directly on the policy issues of the day. A number of important agricultural economic research centers are being developed in Brazil, but none of them so far are attempting to remain close to the policy making process, nor are they attempting to orient their research programs so that they will be directly useful to policy makers.

Brazil is a huge country, with quite varied regional economies. It is important that a number of strong regional research centers be developed, building on the few existing institutions where possible. The importance of regional centers can be seen when it is recognized that the state of Minas Gerais, for example, is larger in area than France and has a greater population than all except two Iatin American countries. Moreover, the economic problems of the several regions are uniquely different--the contrast between the South and the Northeast being a case in point.

In addition to these regional centers, it is important that at least one institution be developed that specializes in national policy research. Such an instituition should not be left with a monopoly in this field, however, since the cross checking that comes from various institutions working on the same problem is an important means of obtaining rigor in economic analysis. Each regional center 
should concentrate at least some fraction of its resources on problems of a national level.

Within the institutions, care should be taken that a balance is struck between problems of a shortrun nature and of a longer-run nature. Once the capacity for economic analysis is developed, it is very likely that the demands for short-term analyses, to facilitate short-term planning, will be enough to swamp the staff capacity that is likely to be developed in the near future. It is important that some attention be given to understanding the nature of the Brazilian economy, and that an analysis of the problems of longer-run import be made.

Finally, the importance of developing an adequate data base cannot be overemphasized. Modern economic research is empirical in nature, and policy decisions can be no better than the underlying data on which they are based. The data collection system in Brazil needs to be reformed, with an increasing reliance placed on modern sampling theory and procedures.

\section{Improved Market Reporting Services}

The provision of current information on product markets is a key factor in making these markets function more efficiently. This is a service that usually must be provided by the government sector. A market news service is beginning to evolve in Brazil. This system should be strengthened and expanded as rapidly as possible.

Improved Administrative

Organization and Training

An improved organizational structure can make for more effective use of the resources being channeled to agriculture through the public sector. Moreover, the development of administrative talent in these organs could make a significant contribution. To the extent possible, action in these directions should be taken. 


\section{CONCLUDING COMMENTS}

Brazil's agricultural sector has a great deal of potential. Although rather neglected in the postwar period, it has the endowment of natural resources to make it an important component of the total economy. Were it to be strengthened, it could make a major contribution to the development of the total economy.

Efforts at developing the agricultural sector should be addressed to modernizing it and raising its productivity. Increases in food production will come about as an incidental part of this process, and the increase in productivity will enable this sector to make a greater contribution to the total development process.

It is important to view the agricultural development process in the context of the total economy. Development efforts should be directed not just to agriculture, but also to the industries supporting it. The benefits of such an approach will be widespread. Strengthening the supply industries will provide expanding employment opportunities, and at the same time provide the industrial sector with a much broader base. Upgrading the educational levels in the rural areas will not only provide higherquality labor for the agricultural sector, but also higher-quality labor for the non-farm sector. It will reduce the adjustment problem of the migrants, and should alleviate the accumulation of unskilled, unemployable labor forces in the large cities.

The regional imbalance in Brazil is a serious problem. It is difficult to overemphasize this. The problem is as serious in the farm sector as it is in the non-farm sector. The southern part of Brazil is well on its way towards achieving selfsustaining development. It has a reasonably productive agricultural sector and the basis for a strong industrial sector.

However, the Northeast, despite the concentrated efforts in the period since 1960, has very low income levels, a very limited amount of industry, and an agricultural sector that is quite weak. Most of the development efforts in this region have been directed 
to the industrial sector, with agriculture receiving only passing attention.

It could be argued that agricultural development efforts should be channeled to those areas already having a strong agriculture, or that have strong agricultural potential. However, the point remains that an important fraction of the population resides in the Northeast, and it is not at all clear that with an expanded research effort, this region cannot expand its agricultural output substantially. Strong efforts should be made to strengthen the research and educational research infrastructure in this region.

In the context of general economic policy, strong steps have been taken in the right direction in recent years. Inflation is being brought under control, and some costly subsidies have been eliminated. Exports are now being encouraged, the exchange rate has been brought closer to equilibrium, and some of the distortions in the domestic economy have been reduced.

However, development efforts have still concentrated heavily on developing the physical infrastructure, to the relative neglect of the educational and technological aspect of the problem. Roads and dams are being built at a rapid rate. But schooling and training, although expanding, still remain miminal in relation to the size of the problem being faced. And the amount of money being spent for research is indeed small. The greatest needs at this point in time would appear to be for lower-level education on a mass scale, and for investments in research.

It should be recognized that success in the development of the agricultural sector will likely lead to serious labor adjustment problems. The migration out of the agricultural sector will probably take place at a higher rate, and it appears that the non-farm sector is already having a difficult time absorbing the existing flow. Moreover, there are likely to be serious regional aspects to this problem.

Two points should be stressed. First, balance will have to be maintained in the national development policies. Although we have argued strongly for the strengthening of the agricultural sector, we would by no means argue that the non-farm sector 
should be ignored. Rather, we have argued that efforts directed towards the agricultural sector should be concerned with raising its productivity so that it could contribute to the development of the total economy. The vehicle we see for doing this is the adoption of a higher level of technology and investments in people in the form of education. Our policy recommendations were oriented in this direction.

Second, the problem will have to be faced. Even though adjustment problems arise, it is better to face these directly, and attempt to solve them, than to avoid the problem by not developing and strengthening the agricultural sector. Education will go a long way towards alleviating some of these adjustment problems, but it will most likely be necessary to develop strong manpower programs in order to facilitate the adjustment of the labor force to the job opportunities. Such programs can contribute significantly to the total development of the economy.

NOTES

1. See CIDA, Land Tenure Conditions and SocioEconomic Development of the Agricultural Sector (Brazil) (Washington, D.C.; Pan American Union, 1966); António R. Coutinho, Contribuiçào ao Estudo da Estrutura da Economía Agráría, Segundo o Censo de 1950 (Rio de Janeiro: Ministry of Agriculture, $\overline{1960)}$.

2. For a discussion of the general case for emphasizing research and education in modernizing agriculture, see T. W. Schultz, Transforming Traditional Agriculture (New Haven and London: Yale University Press, 1964).

3. Zvi Griliches, "Research Costs and Social Returns: Hybrid Corn and Related Innovations," Journal of Political Economy, LXVI, 5 (October, 1957), $501-522$.

4. The case of hybrid corn in the United states is not an isolated instance. Dr. Schultz has collated the results from a number of studies that have investigated the social rate of return to investments in agricultural research--The Allocation of Resources to Research, "University of Chicago, Agricultural 
Economics Papers," No. 68:16 (December, 1968). A higher rate (750 percent) was found for the investments in wheat research in Mexico, and rates on the order of 300 percent were found for total expenditures on research in the United States and in Mexico.

5. For example, see Edward F. Denison, The Sources of Economic Growth in the United States and the Alternatives Before Us, Committee for Economic Development, Supplementary Paper No. 13 (1962).

6. For a cost-benefit analysis of schooling in the rural areas of the United States, see Micha Gisser, "A Benefit-cost Analysis of Investment in Schooling in Rural Farm Areas," American Journal of Agricultural Economics, V, 3 (August, 1968), 621629 .

7. For a systematic treatment, see D. Gale Johnson, Forward Prices for Agriculture (Chicago: University of Chicago Press, 1947).

8. Euter Paniago has examined both the social costs and the treasury costs of alternative price policies for three important food products in Brazil. See "An Evaluation of Agricultural Price Policies for selected Food Products: Brazil" (unpublished Ph.D. thesis, Purdue University, 1969).

9. For an inventory and evaluation of agricultural economics research in Brazil, plus an assessment of the state of the profession, see $G$. Edward Schuh, Research On Agricultural Development in Brazil (New York: The Agricultural Development Council, forthcoming). 



\section{EP ILOGUE}

It is quite common for students of the Brazilian economy to be critical of the agricultural sector. This criticism does not appear to be well placed. Given the relative neglect by policy makers, and the restrictions placed on it through trade policy, the agricultural sector has performed exceedingly well. output in the aggregate has expanded at about the same rate that demand has increased, and the agricultural sector not only has supplied large amounts of capital for the development of the industrial sector, but also has supplied an expanding labor force for the non-farm sector.

This does not mean that all is well with Brazilian agriculture, nor that it has made the maximum contribution to general development that it might have made. Incomes in the farm sector are quite low in relation to those in the non-farm sector, and the level of technical efficiency in the aggregate is quite low. Moreover, there are serious regional imbalances within the agricultural sector.

Had efforts been made to raise the level of productivity in the agricultural sector, and had trade policy been such as to capture the gains from this increase in productivity, the development of the total economy might have proceeded at a much more rapid rate. Important quantities of exchange earnings from the agricultural sector were forgone because of the trade policies pursued. The flow of both capital and labor to the non-farm sector might have been much greater if the level of productivity in agriculture had risen.

The extraction of resources from the agricultural sector for the development of the non-farm 
sector is usually a necessary policy if rapid rates of economic development are desired. However, if the agricultural sector is to make its maximum contribution to the development of the economy, investments which raise the level of productivity in the agricultural sector are critical. These investments for the most part require investments in the human agent (schooling) and in the creation of new knowledge (research).

Recent developments in the world at large can have an important impact on Brazilian agriculture. The international centers for agricultural research are in a very real sense effectively lowering the cost to a country such as Brazil of making a given level of technical change. They have already developed improved varieties of rice, corn, and wheat-three important crops for Brazil--that are adaptable to a wide range of ecological conditions. The recently established centers expect to concentrate on a much wider range of tropical products.

It is important that Brazil capitalize on these external technical economies by strengthening its capacity for agricultural research. The new varieties and the new knowledge developed at the international centers will most likely require some adaptive research in order to be directly applicable to Brazilian conditions. However, it should be possible to obtain a given increase in yields with a much smaller expenditure of public funds than if the process were started from scratch. The social rate of return to such adaptive research should be quite high in relation to other alternatives.

At the same time, however, it should be recognized that successful efforts to raise the level of productivity in the agricultural sector will give rise to a second generation of economic problems. This second generation of problems is likely to focus in the labor market, which connects the agricultural sector to the non-farm sector. Increases in productivity in the agricultural sector are very likely to accelerate the rate of migration from agriculture. This is not to be bemoaned, since if appropriate policy measures are taken, this labor can be employed to produce the goods and services associated with a higher standard of living. However, it is important that the appropriate policy measures be taken. 
Education programs of all kinds should be vastly increased, and other steps should be taken to strengthen the infrastructure of the labor market.

A more rapid rate of technical progress is also likely to aggravate the serious regional imbalances in the Brazilian economy. Some areas will have a comparative advantage in the adoption of the new knowledge, while others will be left comparatively disadvantaged. This dimension of the development problem should be given more attention in national planning. 
BIBLIOGRAPHY 


\section{BIBLIOGRAPHY}

Public Documents and Government Publications

Abouchar, Alan. Diagnosis of the Transport Situation in Brazil. Rio de Janeíro: Egcritorio de Pesquisa Economica Aplicada, Ministério do Planejamento e Coordenação Geral (EPEA), 1967.

Anuário Estatístico do Brasil. (annual) Rio de Janeiro: Ingtituto Brasileiro de Geografía e Estatística (IBGE), Serviço Nacional de Recenseamento.

Aspectos do Diagnótico Preliminar da Agricultura. 3 vols. Rio de Janeiro: EPEA, 1966.

Atualidade Estatígtica do Brasil. (annual) Rio de Janeiro: IBGE, Serviço Nacional de Recenseamento.

Censo Demográfico do Brasil, 1940 and 1950. Resultados Prelimináres, 1960. Rio de Janeiro: IBGE, Serviço Nacional de Recenseamento.

Censo Escolar do Brasil, 1964. Resultados Preliminares, Vols. I and II. Rio de Janeiro: Instituto Nacional de Estudos Pedagógicos, Ministerio da Educação e Cultura, 1966.

Coutinho, Antônio R. Contribuicão ao Estudo da Estrutura da Economia Agrária, Segundo o Censo de 1950. Rio de Janeiro: Ministério da Agricultura, 1960.

Crédito Agrícola no Brasil. Rio de Janeiro: EPEA, 1966 .

Demografia, Diagnóstico Preliminar: Plano Decenal de Desenvolvimento Econ6́mico e Social. Rio de Janeiro: EPEA, 1966. 
A Estrutura Agrária Brasileira. Rio de Janeiro: Instituto Brasileiro de Reforma Agrária, 1968.

Estrutura do Comércio Exterior do Brasil, 1920-1964. 2 vols. Rio de Janeiro: Fundaçăo Getúlio vargas, 1964 .

Manual de Estatísticas Básicas do Nordeste. Fortaleza: Departamento de Estudos Económicos do Nordeste (ETENE), Banco do Nordeste, 1968.

A Industrializacào Brasileira: Diagnóstico e Perspectivas. Rio de Janeiro: EPEA, 1968.

Orcamento Programa. Rio de Janeiro: Ministério do Planejamento e Coordenaçào Geral, 1965.

Plano Decenal de Desenvolvimento Econômico e Social. Rio de Janeiro: Instituto de Pesquisa Econômico-Social Aplicada, Ministério do Planejamento e Coordenaçào Geral, 1968.

Plano Trienal de Desenvolvimento Econômico e Social, 1963/1965 (Sintese). Rio de Janeiro: Presidência da República, 1962.

Programa de Acāo do Govêrno, $1964 / 1966$ (Síntese). Rio de Janeiro: Ministério do Planejamento e Coordenaçăo Geral, 1964.

Programa Estratégico de Desenvolvimento, 1968-1970. Vols. I and II. Rio de Janeiro: Ministério do Planejamento e Coordenaçāo Geral, 1968.

Programa Estratégico de Desenvolvimento, Agricultura e Abastecimento. Rio de Janeiro: Ministério do Planejamento e Coordenaçāo Geral, 1968.

Program Estratégico de Desenvolvimento, Agricultura e Abastecimento. Rio de Janeiro: Ministério do Planejamento e Coordenacão Geral, 1968.

Relatório. (annual) Rio de Janeiro:

Superintendência da Moeda e do crédito.

Relatório do Banco do Brasil (annual) Rio de Janeiro: Banco do Brasil.

Zoneamento Agrícola e Pecuário do Brasil, Espécies Económicas has Diferentes Regiós. Rio de Janeiro: EPEA, 1966. 
Books

Anaral, Luis. Hist6ria Geral da Agricultura Brasileira. 2 vols: Sao Paulo: Companhia Editora Nacional, 1958.

Amaral, Pompeo de. o Problema da Alimentacão.

Rio de Janeiro: Livraria José Olympio, 1963.

Aspectos da Inflacão Brasileira e Suas Perspectivas para 1965. ("Estudos ANPES," No. 1.) Rio de Janeiro: Associaçào Nacional de Programaçāo Económica e Social (ANPES), 1965.

Baer, Werner. Industrialization and Economic Development in Brazil. Homewood, III.: Richard D. Irwin, 1965. (Also available in Portuguese.)

Baerresen, Donald $W$. et al. Latin American Trade Patterns. Washington, D.C.: The Brookings Institution, 1965 .

Becker, Gary. Human Capital. New York: Columbia University Press, 1964.

Bello, José Marin. A History of Modern Brazil, 1889-1964. Stanford, California: Stanford University Press, 1966.

Benjamin, H.R.W. Higher Education in the American Republics. New York: McGraw-Hill, 1965.

Castro, Josue de. Geografia da Fome. 9 th rev. ed. São Paulo: Editôra Brasileira, 1965.

Comite Interamericano de Desenvolvimento Agrícola (CIDA) . Land Tenure Conditions and SocioEconomic Development of the Agricultural Sector, Brazil. Washington, D.C.: Pan-American Union, 1966.

Daland, Robert T. Brazilian Planning, Development Politics, and Administration. Chapel hill: University of North Carolina Press, 1967. 
Dalrymple, Martha. The AIA Story, Two Decades of International cooperation. New York: American International Association for Economic and Social Development (AIA), 1968.

Delfim Netto, Antônio. O Problema do Café no Brasil. Rio de Janeiro: Análise e Perspectiva Econômica (APEC) Edit6ra, S.A., 1959.

Denison, Edward F. The Sources of Economic Growth in the United states and the Alternatives Before Us. Committee for Economic Development, Supplementary Paper No. 13. 1962.

A Economia Brasileira e Suas Perspectivas. (ANPES, "Estudos APEC," No. VII.) Rio de Janeiro: APEC Editôra, S.A., 1968.

Furtado, Celso. The Economic Growth of Brazil, a Survey From Colonial to Modern Times. Berkeley: University of California Press, 1963.

Graner, E.A. and Godoy, Jr., E.C. Culturas da Fazenda Brasileira. São Paulo: Ediçóes Melhoramentos, 1962 .

Harris, Marvin. Town and Country in Brazil. New York: Columbia University Press, 1956.

Hirschman, Albert 0 . Journeys Toward Progress: Studies of Economic Policy-Making in Latin America. New York: Twentieth Century Fund, $19 \overline{3}$.

Leff, Nathaniel H. Economic Policy-Making and Development in Brazil, 1947-1964. New York: John Wiley and Sons, Inc., 1968.

Lima, J. Pinto, et al. Técnicos para o Desenvolvimento da Agricultura. Rio de Janeiro: Associaçao Brasileiro de Crédito e Extensão Rural (ÁBCAR), 1961.

Loeb, G.F. Industrialization and Balanced Growth: With Special Reference to Brazil. Groningen, Netherlands: J.B. Wolters, 1957.

Luz, Nícia V. da A Luta Pela Industrializacão do Brasil. São Paulo: Difusào Européia do Livro, 1961. 
Johnson, D. Gale. Forward Prices for Agriculture. Chicago: University of Chicago Press, 1947.

Klein and Saks. O Problema da Alimentação no Brasil. Rio de Janeiro: Comissão de Desenvolvimento Industrial, 1954.

Marketing Facilities for Grain and Tuberous Crops: Brazil. 2 vols. Kansas City, Missouri: Weity Hettelsater Engineers, 1964.

Meijer, H. Rural Brazil at the Crossroads. Wageningen, Netherlands: $\mathrm{H}$. Veenman \&onen, 1951 .

Neiva, A.H. "The Population of Brazil," in J.M. Stycos and J. Airos, et al., Population Dilemma in Latin America. Washington, D.C.: Potomac Books, 1966.

Nicholls, William H. and Paiva, Ruy M. Ninety-Nine Fazendas: The Structure and Productivity of Brazilian Agriculture, 1963. Nashville, Tenn: Graduate Center for Latin American Studies, vanderbilt University. (Preliminary edition.)

Pastore, José. Satisfação de Migrantes de Brasillia: Uma Interpretacăo Sociologica. São Paulo: Companhia Editôra Naciona1, 1969.

Prado, Jr., Caio. The Colonial Background of Modern Brazil. Berkeley: University of California Press, 1967.

A Reforma Agrária. Problemas, Bases, Solucão. Rio de Janeiro: Instituto de Pesquisas e Estudos Sociais, 1964 .

Ribeiro, Jose P. and Wharton, Jr., Clifton R. "The ACAR Program in Minas Gerais, Brazil," in Clifton R. Wharton, Jr., ed., Subsistence Agriculture and Economic Development. Chicago: Aldine Publishing Co., 1969.

Robock, Stefan H. Brazil's Developing Northeast: A Study of Regional Planning and Foreign Aid. washington, D.C.: Brookings Institution, 1963.

Rodriguez, José $\mathrm{H}$. The Brazilians, Their Character and Aspirations. Austin: University of Texas Press, 1967. 
Ruttan, Vernon W. "Notes on Agricultural Product and Factor Markets in Southeast Asia," in Kurt R. Anschel et al., eds.. Agricultural Cooperatives and Markets in Developing Countries. New York: Frederick A. Praeger, 1969.

Schuh, G. Edward. Research on Agricultural Development in Brazil. New York: Agricultural Development Council. (Forthcoming.)

Schultz, Theodore $w$. The Economic Value of Education. New York: Columbia University Press, 1963.

- Transforming Traditional Agriculture. New Haven and London: Yale University Press, 1964.

- Economic Crises in World Agriculture. Ann Arbor: The University of Michigan Press, 1965 .

Slater, Charles, et al. Market Processes in the Recife Area of Northeast Brazil. (Research Report No. 2, Latin American Studies Center.) East Lansing: Michigan State University Press, 1969.

Smith, Gordon W. "Brazilian Agricultural Policy: 1950-1967," in Howard S. Ellis, ed., Essays on the Economy of Brazil. Berkeley and Los Angeles: University of California Press, 1969.

Smith, T. Lynn. Brazil: People and Institutions. 3rd rev. ed. Baton Rouge: Louisiana state University Press, 1963.

Smith, T. Lynn, and Marchant, Alexander, eds., Brazil: Portrait of Half a Continent. New York: Drydon Press, 1951.

Stilman, Meyer. o Comercio varejista e os Supermercados na Cidade de Săo Paulo. 2 vols. Săo Paulo: Faculdade de Economia e Ciencias Administrativas, Universidade de são Paulo, 1962 .

Villaça, Maria J. A F6rca de Trabalho no Brasil. São Paulo: Editôra Pioneira Limitada, 1967. 
wagley, Charles. An Introduction to Brazil. New York: Columbia University Press, 1963.

Reports and Bulletins

Agri Research, Inc. Economic and Technical Feasibility of Increased Manufacture and Use of Fertilizers, Agricultural Limestone, and Limestone Materials in Brazil. (Report to the Ministry of Agriculture, Government of Brazil, and office of Agriculture and Rural Development, USAID/Brazil.) Darien, Conn., 1964. (Aĺso available in Portuguese.)

Agri Research, Inc. Recommendations for ManufactureDistribution of Agricultural Minerals in Brazil. Manhattan, Kan .: Agri Research, Inc. and Wichita, Kan.: Litwin Engineering Co., Inc., 1964.

Barber, Fred w. The origin and Development of Brazil's Cooperative Agricultural Extension Service. Rio de Janeiro: ABCAR, n.d.

Barr, George $w$. Agricultural Development in Northeast Brazil's Dry Polygon. Report to the Government of Brazil, FAO NO. 1765. Rome: FAO, 1963.

CIDA. Inventory of Information Basic to the Planning of Agricultural Development in Latin America. Washington, D.C.: Pan-American Union, 1966.

Conjuncta Econômica. (monthly) Rio de Janeiro: Fundaçao Getúlio vargas.)

As Estruturas de Consumo e os Orcamentos Familiares. Rio de Janeiro: Fundaçăo Getblio Vargas, 1968.

FAO. VII Conferência Regional da FAO para América Latina, Documentos Basicos da Delegacáo Brasileira. 1962 .

Galvão, Olavo J. O Desenvolvimento Econ6mico do . Nordeste. Fortaleza: Banco do Nordeste, 1955.

Indicador de Experimentos Agrícolas. Rio de Janeiro: ABCAR, 1961 . 
A IndGstria de Alimentos no Brasil. Rio de Janeiro: Instituto Brasileiro de Economia, Fundação Getalio Vargas.

Livestock in Latin America, Brazil: status, Problems and Prospects. Rome: FAO, 1964.

Miller, Clarence $J$. and Felton, John R. "A Critique of Government Ownership and Operation of Surface Media in Brazil," in Papers of the Transportation Research Forum, Seventh Annual Meeting, 1966.

Municfpios Onde se Concentra a Producão Agrfcola Brasileira. Rio de Janeiro: Fundaça Getalio Vargas, 1967.

Nutrition Survey - Northeast Brazil. Washington, D.C.: a report by the U.S. Interdepartmental Committee on Nutrition for National Development, 1965.

Plano Diretor. Rio de Janeiro: ABCAR, 1960.

Projections of Supply and Demand for Agricultural Products of Brazil Through 1975. Rio de Janeiro: IBRE, Fundaçăo Getulío vargas, 1968. (Also published by United states Department of Agriculture.) (Available in Portuguese from the Fundacão GetGlio Vargas as Projecões de Oferta e Demanda de Produtos Agricolas Para o Brasi1.)

Relatorio das Atividades da SUDENE em 1965. Recife: Superintendency for the Development of the Nor theast (SUDENE), 1966.

Survey of the Agricultural Potential of the Central Plateau of Brazi1. New York: AIA, 1963.

21 Anos de Evolucão da Agricultura. Rio de Janeiro: Fundaçáo Getûlio Vargas, 1969.

Yudelman, Montague. Agricultural Development in Latin America: current Status and Prospects. Washington, D.C.: Inter-American Development Bank, 1966. 
Zonas Fisiograficas onde se Concentra a Producão Agricola Brasileira. Rio de Janeiro: Fundação Getulio Vargas, 1967.

\section{Articles}

Baer, Werner. "Regional Inequality and Economic Growth in Brazil," in Economic Development and Cultural Change, XII, 3 (April, 1964), 268-85.

Baer, Werner, Kerstenetzky, Isaac, and Simonsen, Mario H. "Transportation and Inflation: A Study of Irrational Policy-Making in Brazil," in Economic Development and Cultural Change (January, 1965).

"Contas Nacionais do Bras11, 1947/1961," Revista Brasileira de Economia (March, 1962).

Dias, Rubens $A$. and Paiva, Ruy M. "Recente Evolução da Agricultura em Sao Paulo," in Agricultura em Sao Paulo, VII, 1 (January, 1960), 3-40.

Economic Commisgion for Latin America (ECLA). "Fifteen Yearg of Economic Policy in Brazil," in Economic Bulletin for Latin America, IX (November, 1964), 170-97.

Ettori, Oscar J.T. "Produtividade FIsica da Agricultura em são Paulo," in Agricultura em Săo Paulo, XI, 7 (July, 1964), 3-48.

Graham, Douglas. "Divergent and Convergent Regional Economic Growth and Internal Migration in Brazil, 1940-60," in Economic Development and Cultural change. (Forthcoming.)

Gisser, Micha. "A Benefit-Cost Analysis of Investment in schooling in Rural Farm Areas," in American Journal of Agricultural Economics, III (Äugust, 1968), 621-29.

Griliches, zvi. "Research Costs and social Returns: Hybrid Corn and Related Innovations," in Journal of political Economy, LXVI, 5 (October, 1957), $501-22$. 
- "Research Expenditures, Education and the Aggregate Agricultural production Function," in American Economic Review, LIV (December, $1 9 6 4 \longdiv { 4 }, 967-78$.

"The Sources of Measured Productivity Growth: United States Agriculture, 1940-1960," in The Journal of Political Economy, LXXI, 4 (August, 1963), 331-62.

Leff, Nathaniel. "Export stagnation and Autarkic Development," in quarterly Journal of Economics, LXXXI (May, 1967), 286-301.

Munk, Bernard. "The Welfare costs of Content Protection: The Automotive Industry in Latin America," in Journal of Political Economy, LXXVII, 1 (January/February, 1969), 85-98.

Nicholls, William S. and Paiva, Ruy M. "Structure and Productivity of Brazilian Agriculture," in Journal of Farm Economics, XLVII, 2 (May, 1965), 347-61. (Also published in Revista Brasileira de Economia, Ano XIX, No. 2 , June, 1965.)

Paiva, Ruy M. "The Development of Brazilian Agriculture," Journal of Farm Economics, XLIII, 5 (De cember, 1961).

- "Reflexos SObre as Tendências da Prođução, da Produtividade e dos Preços do Setor Agrícóla do Brasil," in Revista Brasileira de Economia (September, 196 $\overline{6}$ ).

Paiva, Ruy M. and Nicholls, William H. "Estágio do Desenvolvimento Técnico da Agricultura

Brasileira," in Revista Brasileira de Economia (September, 1965), 27-63.

Panagides, Stahis. "Erradicação do Café e Diversificação da Lavoura no Brasil," in Revista Brasileira de Economia (1968).

Sahota, Gian S. "An Analysis of Internal Migration in Brazil," in The Journal of Political Economy, LXXVI, 2 (March7Apri1, 1968), 218-45. 
Schuh, G. Edward. "Alguns Aspectos do Problema de Recursos Humanos na Agricultura Brasileira," in Revista de Economia Rural, I, 1 (June, 1968), $411-27$.

- "Effects of Some General Economic Development Policies on Agricultural Development," in American Journal of Agricultural Economics, L, 5 (December, 1968), 1283-93.

Wharton, Jr., clifton R. "The Economic Impact of Technical Assistance: A Brazilian Case Study," in Journal of Farm Economics, XLII, 2 (May, $1960), 252-67$.

Witt, Lawrence $w$. "Changes in the Agriculture of South Central Brazil," in Journal of Farm Economics, XXV, 3 (August, 19 $\overline{43}$ ), 622-43.

Youmans, Russell and Schuh, G. Edward. "An Empirical study of the Agricultural Labor Market in a Developing Country: Brazil," in American Journal of Agricultural Economics, $\overline{\mathrm{L}, 4}$ (November, 1968), 943-61.

Unpublished Material

Almeida, M.L. Rodrigues de. "A Task for Brazilian Agriculture: Some Aspects of the Gap Between Actual Consumption and That Based on an Adequate Diet in 1960 and $1970 . "$ Special report prepared for the CIDA study. Washington: PanAmerican Union.

Alves, Eliseu R.A. and Schuh, G. Edward. "An Economic Evaluation of the Impact of an Extension Program: ACAR, Minas Gerais, Brazil." West Lafayette, Ind.: Purdue University, 1969. (Mimeographed.)

Baer, Werner and Maneschi, Andres. "Import-substitution, Stagnation and structural Change, an Interpretation of the Brazilian Case," Nashville, Tenn.: Graduate Center for Latin American Studies, Vanderbilt University, 1969. (Mimeographed.) 
Ginze1, John. "Importance and Characteristics of the Agricultural sector in Brazil." Purdue University, 1968 (Mimeographed.)

Krug, C. A. "summary Appraisal of Potential Increases in Agricultural Production." (Based exclusively on technical factors.) Special report prepared for the CIDA Study. Washington, D.C.: PanAmerican Union, $n . d$.

Ministerio da Agricultura. "Indicador dos Trabalhos de Pesquisas e Experimentação." Rio de Janeiro: Itaguai, 1961. (Mimeographed.)

Paniago, Euter. "An Evaluation of Agricultural Price Policies for Selected Food Products: Brazil." Ph.D. thesis, Purdue University, 1961.

Schuh, Maria Ignez Angeli. "A Adoção de Nova Technologia na Agricultura, Municlpio de Campinas, 1963-64." Master's thesis, Instituto de Economia Rural, Rural University of Minas Gerais (UREMG), 1967.

Schultz, Theodore $W$. "The Allocation of Resources to Research," in University of Chicago Agricultural Economics Papers, 68:16. December, 1968.

Smith, Gordon W. "Agricultural Marketing and Economic Development: A Brazilian Case Study." Ph.D. thesis, Harvard University, 1965.

Thompson, Robert L. "The Impact of Exchange Rate Policy and other Restrictive Policies on corn Exports in Brazil." Master's thesis, Purdue University, 1969.

Watsted, Otto. "On the Structure of Regional Economic Differentials: Brazil's Northeast and Italy's Mezzogiorno." Master's thesis, Massachusetts Institute of Technology, 1966.

Webb, Kempton. "A Geography of the Food supply in Central Minas Gerais, Brazil." Ph.D. thesis. Syracuse University, 1958. 


\section{ABOUT THE AUTHORS}

G. EDWARD SCHUH, Professor of Agricultural Economics at Purdue University, has worked as Program Advisor in Agriculture for the Ford Foundation in Brazil since 1965. Dr. Schuh has spent several years in research of agricultural factor markets and in graduate teaching at Purdue and also at the Rural University of Minas Gerais in Viçosa, Brazil, under an AID contract with Purdue University. Dr. Schuh helped to develop the first graduate program in agricultural economics in Latin America, and in 19.65, he was granted the honorary title Professor Honoris Causis by the Rural University of Minas Gerais for his work there. He has contributed to several books, and his articles have appeared in many agricultural and economic journals. He received both his M.A. and his $\mathrm{Ph} . \mathrm{D}$. from the University of Chicago.

ELISEU ROBERTO DE ANDRADE ALVES, a native of Brazil, has been on the staff of the Extension Service of the Minas Gerais state (ACAR) since 1955, and is now Head of the Department of Programming and Evaluation for that organization. Mr. Alves received his M.A. in Agricultural Economics from Purdue University and expects to receive his $\mathrm{Ph} . \mathrm{D}$. soon from the same university. 
other activities in 1950 (the most recent year for which data are available). The remainder were in domestic activities or in school (38 percent), or inactive ( 31 percent). But of the fraction of this age group who were working, 87 percent were in agriculture. This point should be kept in mind when comparing gross productivity figures. The percentage of child labor has probably declined because of higher edu ation attainments, but it still remains relatively high.

11. For a limited analysis of the labor market within the agricultural sector of Minas Gerais, and its relationship to the non-farm labor market, see Russell Youmans and G. Edward Schuh, "An Empirical Study of the Agricultural Labor Market in a Developing Country: Brazil," American Journal of Agricultural Economics, L, 4 (November, 1968), 943-961.

12. Entrepreneurs who established industries which substituted imports were afforded easier access to the credit market and, at times, at highly subsidized rates.

13. For a more detailed analysis, see G. Edward Schuh, "Alguns Aspectos do Problema de Recursos Humanos na Agricultura Brasileira," Revista de Economía Rural, I, 1 (June, 1968), 4T1-427. 


\section{CHAPTER 2 AGRICULTURE'S \\ ROLE IN \\ THE ECONOMY}

Agriculture has until recent years been the major sector of the Brazilian economy. It has produced the major share of the gross national product (GNP), provided the major share of employment opportunities, and been the major source of export earnings. It has participated in the rapid growth of the economy in the postwar period. It has not, however, made the contribution to that growth that it could have, had more rational economic policies been followed.

In the post-World War II period the agricultural sector has been quite weak politically. This is due in part to the combination of rapid urbanization, the provision of educational opportunities primarily in the urban areas, and an electoral law that requires literacy as a basis for voter qualification. The result of this weak political position has been laws and policies that discriminated against the agricultural sector, and, on the surface, at least, favored the consumer and the non-farm sector.

The government in the postwar period, especially in the latter half of the 1950's, concentrated on industrialization. This industrialization was directed largely to a market of high-income earners, but it modernized some sectors of the economy to an astounding degree in a relatively short time period. The triangle formed by Rio de Janeiro, Belo Horizonte, and são paulo has become a source of new employment opportunities and has attracted migrants from all over the nation.

This rapid modernization has not, however, ex $\rightarrow$ tended itself in a general way to the agricultural sector. Some parts of agriculture, especially that in the state of são Paulo, are modernizing. But 